\title{
Evaluation of Streamflow Requirements for Habitat Protection by Comparison to Streamflow Characteristics at Index Streamflow-Gaging Stations in Southern New England
}

By David S. Armstrong, Gene W. Parker, and

Todd A. Richards (Massachusetts Division of Fisheries and Wildlife)

In cooperation with the

Massachusetts Department of Conservation and Recreation; and the

Massachusetts Department of Fisheries, Wildlife, and Environmental Law Enforcement, Massachusetts Division of Fisheries and Wildlife

Water-Resources Investigations Report 03-4332

\section{U.S. Department of the Interior}

U.S. Geological Survey 


\section{U.S. Department of the Interior \\ Gale A. Norton, Secretary}

\section{U.S. Geological Survey \\ Charles G. Groat, Director}

U.S. Geological Survey, Reston, Virginia: 2004

For sale by U.S. Geological Survey, Information Services

Box 25286, Denver Federal Center

Denver, C0 80225

For more information about the USGS and its products:

Telephone: 1-888-ASK-USGS

World Wide Web: http://www.usgs.gov/

Any use of trade, product, or firm names in this publication is for descriptive purposes only and does not imply endorsement by the U.S. Government.

Although this report is in the public domain, permission must be secured from the individual copyright owners to reproduce any copyrighted materials contained within this report. 


\section{Contents}

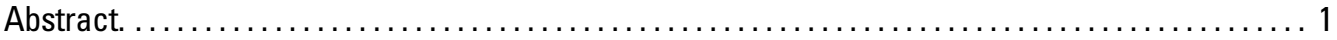

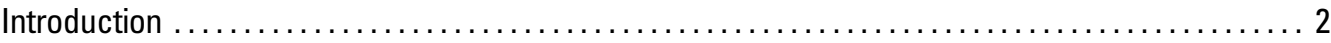

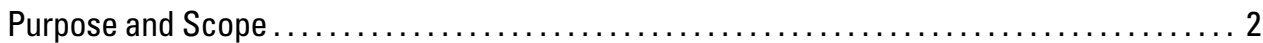

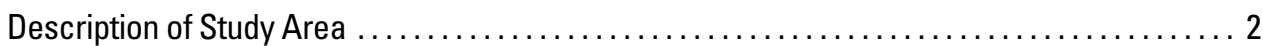

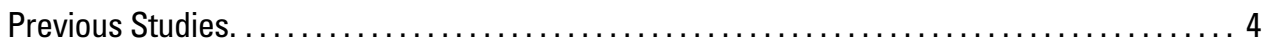

Relations among Flow Regimes, Stream Processes, and Aquatic Habitat ............. 5

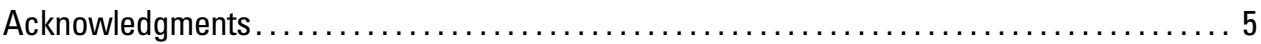

Streamflow Characteristics at Index Streamflow-Gaging Stations in Southern New England . . . . . 5

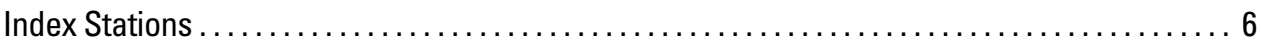

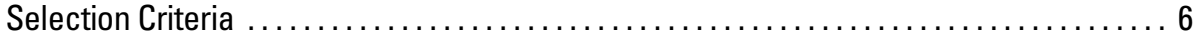

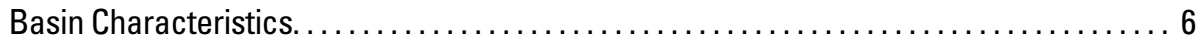

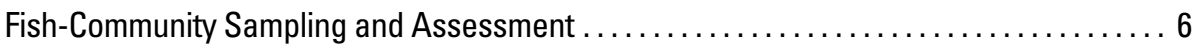

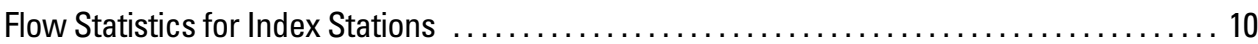

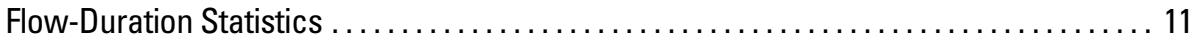

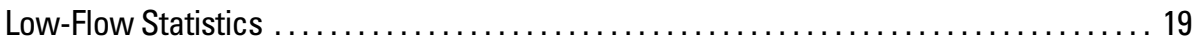

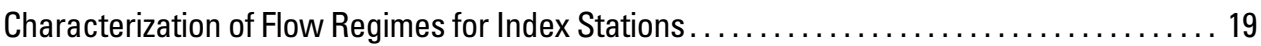

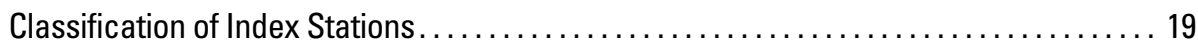

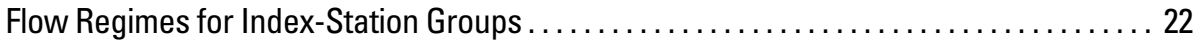

Streamflow Variability for Groups of Index Stations ....................... 24

Streamflow Requirements for Habitat Protection at Index Stations in Southern New England . . . . . 27

Methods for Determining Streamflow Requirements Based on Hydrologic Records ........ 28

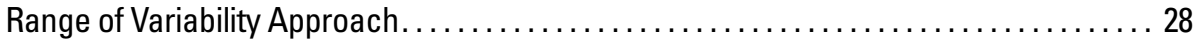

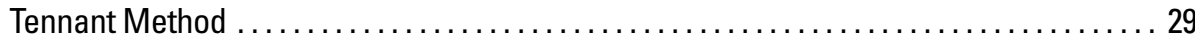

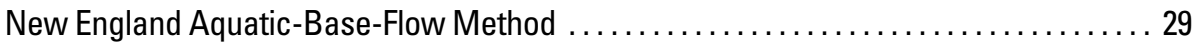

Streamflow Requirements Determined from Hydrologic Records $\ldots \ldots \ldots \ldots \ldots \ldots \ldots \ldots \ldots$

Range of Variability Approach..................................... 30

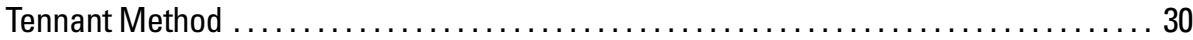

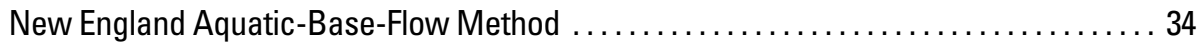

Methods for Determining Streamflow Requirements Based on Hydraulic Ratings ......... 34

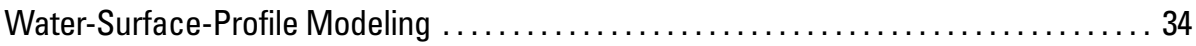

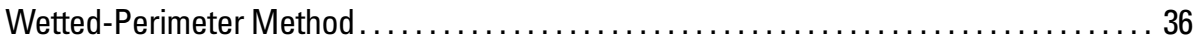

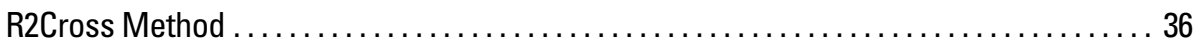

Streamflow Requirements Determined from Hydraulic Ratings $\ldots \ldots \ldots \ldots \ldots \ldots \ldots \ldots \ldots$

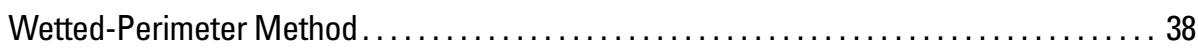

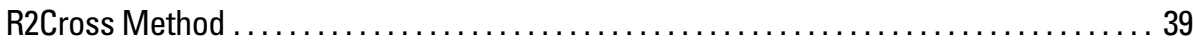

Evaluation of Streamflow Requirements. $\ldots \ldots \ldots \ldots \ldots \ldots \ldots \ldots \ldots \ldots \ldots \ldots \ldots \ldots \ldots, 41$

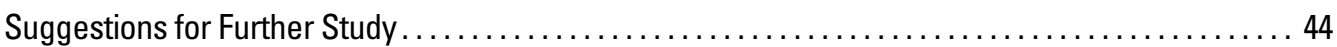

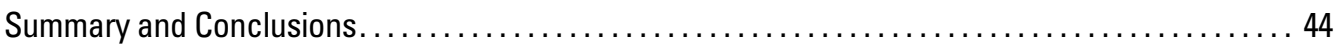

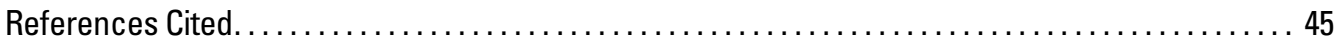


Appendix 1: Annual Flow-Duration Curves for 10 Index Streamflow-Gaging Stations in

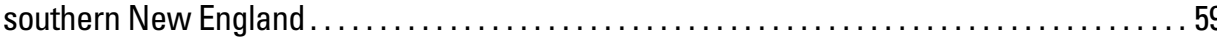

Appendix 2: Procedures for Application of the Wetted-Perimeter Method

Appendix 3: Study-Site Descriptions, Documentation of Input, Calibration Data for HEC-RAS Models, and Hydraulic Variables Simulated by Calibrated HEC-RAS Models for 10 Index Streamflow-Gaging Stations in Southern New England ...

\section{Figures}

1. Map showing location of index stations, and riffle study sites, southern New England ..... 3

2. Photograph showing Massachusetts Division of Fisheries and Wildlife and U.S. Geological Survey personnel identifying, counting, and measuring fish collected by electrofishing. 9

3, 4. Graphs showing:

3. Annual flow-duration curves for Wood River near Arcadia, RI (01117800), and Green River at Williamstown, MA (01333000), for water years 1976-2000 13

4. August streamflows at the Sevenmile River near Spencer, MA (01175670):

A, August daily mean hydrographs for 1990, 1978, and 1977 water years;

$B$, August monthly fduration curves for 1990, 1978, and 1977 water years; and

C, August median monthly duration curve, for water year 1976-2000 15

5. Map showing classification of index streamflow-gaging stations in southern New England

6-8. Graphs showing:

6. Regionalized medians of the 50-percent monthly flow durations, normalized by drainage area, for index stations grouped by $A$, geographic region, NovemberMay; and $B$, magnitude of median 50-percent monthly flow durations, June-October

7. Median monthly flow durations, normalized by drainage area, and the interquartile range about the $25-, 50$-, and 75 -percent monthly flow durations for June through October for the high- and low- median monthly flow-duration groups for index stations: $A$, June; $B$, July; $C$, August; $D$, September; and

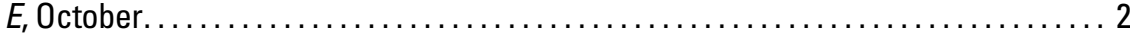

8. Median of average daily discharge for n-day low-flow statistics, normalized by drainage area, for the high- and low-median monthly flow-duration groups, for index stations for water years 1976-2000

9. Schematic showing $A$, cross section of stream channel; and $B$, relation between wetted perimeter and discharge

10. Graphs showing comparison of Range of Variability Approach flow-management targets, normalized by drainage area, to the 25th and 75th percentiles of the 50-percent monthly flow duration for the: $A$, low monthly flow-duration group; $B$, high monthly flow-duration group.

\section{Tables}

1. Locations, descriptions, and basin characteristics of index stations for flow statistics and determination of streamflow requirements in southern New England. . . . . . . . . 7

2. Scientific names and habitat-use classifications of fish in southern New England ....... 10

3. Percentages of fish in each habitat-use classification sampled in flowing reaches of several river basins in Massachusetts 
4. Location and descriptions of fish sampling stations, fish-sampling date, electrofishing methods and effort, reach length, reach width, and fish numbers

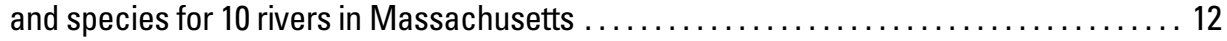

5. Habitat-use classifications for reaches near 10 index stations in Massachusetts....... 12

6. Median and interquartile ranges for 50-percent monthly flow-duration discharges $\left(\mathrm{O}_{50}\right)$, normalized by drainage area, for 23 index streamflow-gaging stations in

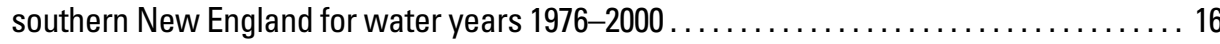

7. Median and interquartile range for $n$-day low-flow statistics, normalized by drainage area, for 23 index stations in southern New England for water years 1976-2000 . . . . . . 20

8. Range of Variability Approach: flow statistics for characterization of hydrologic variation

9. Relations between aquatic-habitat condition and mean annual flow described by the Tennant method for small streams 29

10. Seasonal New England Aquatic-Base-Flow default streamflow requirements 29

11. Range of Variability Approach flow-management targets as defined by the 25th and 75th percentiles of monthly mean flows, normalized by drainage area, for index streamflow-gaging stations in southern New England for water years 1976-2000. . . . . 31

12. The mean annual-flow statistic used by the Tennant and Canadian Atlantic Provinces methods and the streamflows representing summer habitat conditions determined by percentages of the mean annual flow, normalized for drainage area, at 23 index stations in southern New England.

13. Hydraulic criteria for determination of R2Cross streamflow requirements for habitat

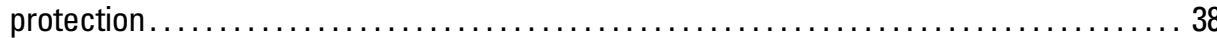

14. Average streamflow requirements determined by the Wetted-Perimeter method for 10 index streamflow-gaging stations in southern New England ....

15. Streamflow requirements and corresponding flow durations determined by the R2Cross method for 10 index streamflow-gaging stations in southern New England . . . . 40

16. Field-determined bankfull discharges for 10 index streamflow-gaging stations in southern New England

17. Summer streamflow requirements and corresponding flow durations for the high-flow group and low-flow groups of index streamflow-gaging stations in southern New England....

18. Flow statistics determined by the Indicators of Hydrologic Alteration Approach, normalized by drainage area, for index streamflow-gaging stations: Wood River, Little River, Squannacook River, Green River in Williamstown, Branch River, and South River. 


\section{CONVERSION FACTORS, VERTICAL DATUM, AND OTHER ABBREVIATIONS}

\begin{tabular}{lcl}
\hline Multiply & By & To obtain \\
\hline cubic feet per second $\left(\mathrm{ft}^{3} / \mathrm{s}\right)$ & 0.02832 & cubic meter per second $\left(\mathrm{m}^{3} / \mathrm{s}\right)$ \\
cubic feet per second per square mile & & cubic meter per second per square kilometer \\
$\left(\mathrm{ft}^{3} / \mathrm{s} / \mathrm{mi}^{2}\right)$ & 0.01093 & $\left(\mathrm{~cm}^{3} / \mathrm{s} / \mathrm{km}^{2}\right)$ \\
foot $(\mathrm{ft})$ & 0.3048 & meter $(\mathrm{m})$ \\
foot per foot (ft/ft) & 1.0 & meter per meter $(\mathrm{m} / \mathrm{m})$ \\
foot per second $(\mathrm{ft} / \mathrm{s})$ & 0.3048 & meter per second $(\mathrm{m} / \mathrm{s})$ \\
inch (in.) & 2.54 & centimeter $(\mathrm{cm})$ \\
inch (in.) & 25.4 & millimeter $(\mathrm{mm})$ \\
square feet $\left(\mathrm{ft}^{2}\right)$ & 0.0929 & square meter $\left(\mathrm{m}^{2}\right)$ \\
square mile $\left(\mathrm{mi}^{2}\right)$ & 259 & hectare $($ ha) \\
\hline
\end{tabular}

Temperature in degrees Celcius $\left({ }^{\circ} \mathrm{C}\right)$ can be converted to degrees Fahrenheit $\left({ }^{\circ} \mathrm{F}\right)$ as follows:

$$
{ }^{\circ} \mathrm{F}=\left(1.8 \mathrm{x}^{\circ} \mathrm{C}\right)+32
$$

Temperature in degrees Fahrenheit $\left({ }^{\circ} \mathrm{F}\right) \mathrm{can}$ be converted to degrees Celcius $\left({ }^{\circ} \mathrm{C}\right)$ as follows:

$$
{ }^{\circ} \mathrm{C}=(-\mathrm{F}-32) \times 0.5555
$$

Sea Level: In this report, vertical coordinate information is referenced to the National Geodetic Vertical Datum of 1929 (NGVD of 1929).

$\begin{array}{ll}\text { ABF } & \text { Aquatic base flow } \\ \text { FD } & \text { Fluvial dependent } \\ \text { FS } & \text { Fluvial specialist } \\ \text { IHA } & \text { Indicators of Hydrologic Alteration } \\ \text { HEC-RAS } & \text { [U.S. Army Corps of Engineers] Hydrologic Engineering } \\ & \text { Center-River Analysis System } \\ \text { HF } & \text { High median monthly flow duration } \\ \text { HSPF } & \text { Hydrologic Simulation Program-Fortran } \\ \text { IQR } & \text { Interquartile Range } \\ \text { LF } & \text { Low median monthly flow duration } \\ \text { MADEP } & \text { Massachusetts Department of Environmental Protection } \\ \text { MG } & \text { Macrohabitat generalist } \\ \text { MDCR } & \text { Massachusetts Department of Conservation and Recreation } \\ \text { MDFW } & \text { Massachusetts Division of Fish and Wildlife } \\ \text { MWRC } & \text { Massachusetts Water Resources Commission } \\ \text { RVA } & \text { Range of Variability Approach } \\ \text { USFWS } & \text { U.S. Fish and Wildlife Service } \\ \text { USGS } & \text { U.S. Geological Survey }\end{array}$




\title{
Evaluation of Streamflow Requirements for Habitat Protection by Comparison to Streamflow Characteristics at Index Streamflow-Gaging Stations in Southern New England
}

\author{
By David S. Armstrong, Gene W. Parker, and Todd A. Richards
}

\section{Abstract}

Streamflow characteristics and methods for determining streamflow requirements for habitat protection were investigated at 23 active index streamflow-gaging stations in southern New England. Fish communities sampled near index streamflow-gaging stations in Massachusetts have a high percentage of fish that require flowing-water habitats for some or all of their life cycle. The relatively unaltered flow condition at these sites was assumed to be one factor that has contributed to this condition.

Monthly flow durations and low flow statistics were determined for the index streamflow-gaging stations for a 25year period from 1976 to 2000 . Annual hydrographs were prepared for each index station from median streamflows at the 50-percent monthly flow duration, normalized by drainage area. A median monthly flow of $1 \mathrm{ft}^{3} / \mathrm{s} / \mathrm{mi}^{2}$ was used to split hydrographs into a high-flow period (November-May), and a low-flow period (June-October). The hydrographs were used to classify index stations into groups with similar median monthly flow durations. Index stations were divided into four regional groups, roughly paralleling the coast, to characterize streamflows for November to May; and into two groups, on the basis of base-flow index and percentage of sand and gravel in the contributing area, for June to October.

For the June to October period, for index stations with a high base-flow index and contributing areas greater than 20 percent sand and gravel, median streamflows at the 50-percent monthly flow duration, normalized by drainage area, were 0.57 , 0.49 , and $0.46 \mathrm{ft}^{3} / \mathrm{s} / \mathrm{mi}^{2}$ for July, August, and September, respectively. For index stations with a low base-flow index and contributing areas less than 20 percent sand and gravel, median streamflows at the 50-percent monthly flow duration, normalized by drainage area, were $0.34,0.28$, and $0.27 \mathrm{ft}^{3} / \mathrm{s} / \mathrm{mi}^{2}$ for July, August, and September, respectively. Streamflow variability between wet and dry years can be characterized by use of the interquartile range of median streamflows at selected monthly flow durations. For example, the median $\mathrm{Q}_{50}$ discharge for August had an interquartile range of 0.30 to $0.87 \mathrm{ft}^{3} / \mathrm{s} / \mathrm{mi}^{2}$ for the high-flow group and 0.16 to $0.47 \mathrm{ft}^{3} / \mathrm{s} / \mathrm{mi}^{2}$ for the low-flow group.

Streamflow requirements for habitat protection were determined for 23 index stations by use of three methods based on hydrologic records, the Range of Variability Approach, the Tennant method, and the New England Aquatic-Base-Flow method. Normalized flow management targets determined by the Range of Variability Approach for July, August, and September ranged between 0.21 and $0.84 \mathrm{ft}^{3} / \mathrm{s} / \mathrm{mi}^{2}$ for the low monthly flow duration group, and 0.37 and $1.27 \mathrm{ft}^{3} / \mathrm{s} / \mathrm{mi}^{2}$ for the high monthly flow duration group. Median streamflow requirements for habitat protection during summer for the 23 index streamflow-gaging stations determined by the Tennant method, normalized by drainage area, were $0.81,0.61$, and $0.21 \mathrm{ft}^{3} / \mathrm{s} / \mathrm{mi}^{2}$ for the Tennant 40-, 30-, and 10-percent of the mean annual flow methods, representing good, fair, and poor stream habitat conditions in summer, according to Tennant. New England Aquatic-Base-Flow streamflow requirements for habitat protection during summer were determined from median of monthly mean flows for August for index streamflow-gaging stations having drainage areas greater than $50 \mathrm{mi}^{2}$. For five index streamflow-gaging stations in the low median monthly flow group, the average median monthly mean streamflow for August, normalized by drainage area, was $0.48 \mathrm{ft}^{3} / \mathrm{s} / \mathrm{mi}^{2}$.

Streamflow requirements for habitat protection were determined for riffle habitats near 10 index stations by use of two methods based on hydraulic ratings, the Wetted-Perimeter and R2Cross methods. Hydraulic parameters required by these methods were simulated by calibrated HEC-RAS models. Wetted-Perimeter streamflow requirements for habitat protection, normalized by drainage area, ranged between 0.13 and $0.58 \mathrm{ft}^{3} / \mathrm{s} / \mathrm{mi}^{2}$, and had a median value of $0.37 \mathrm{ft} / \mathrm{s} / \mathrm{mi}^{2}$. Streamflow requirements determined by the R2Cross 3-of-3 


\section{Streamflow Requirements and Streamflow Characteristics at Index Stations in Southern New England}

criteria method ranged between 0.39 and $2.1 \mathrm{ft} / \mathrm{s} / \mathrm{mi}^{2}$, and had a median of $0.84 \mathrm{ft}^{3} / \mathrm{s} / \mathrm{mi}^{2}$. Streamflow requirements determined by the R2Cross 2-of-3 criteria method, normalized by drainage area, ranged between 0.16 and $0.85 \mathrm{ft}^{3} / \mathrm{s} / \mathrm{mi}^{2}$ and had a median of $0.36 \mathrm{ft}^{3} / \mathrm{s} / \mathrm{mi}^{2}$, respectively. Streamflow requirements determined by the different methods were evaluated by comparison to streamflow statistics from the index streamflow-gaging stations.

\section{Introduction}

Recent low-flow and dry conditions in rivers in Massachusetts have focused attention on the need to identify streamflows that will provide adequate stream habitat to protect the ecological integrity of aquatic ecosystems. Studies in the Ipswich River in northeastern Massachusetts have demonstrated the effects of ground-water withdrawals on streamflow (Zarriello and Ries, 2000), the effects of chronic low flows on stream habitat and fish-community composition (Armstrong and others, 2001), and the effects of watermanagement alternatives on streamflow (Zarriello, 2002). Widespread development and increasing water withdrawals threaten to reduce streamflows in many river systems in Massachusetts, particularly in the eastern portion of the state. Few rivers in eastern Massachusetts are without flow alterations, and there are only a limited number of long-term streamflow-gaging stations whose data could be used as references for restoration efforts. More information is needed about whether riffle-based methods applied in the Ipswich River can be successfully applied to the wide range of streams in Massachusetts.

The Massachusetts Department of Conservation and Recreation (MDCR) and Massachusetts Water Resources Commission (MWRC) are beginning the process of developing statewide streamflow standards. The MDCR in particular is interested in identifying flows that will protect critical habitats needed to sustain aquatic life during summer low-flow periods; however, methods to determine the seasonal and annual streamflow variability needed to maintain the biological integrity of rivers have not been applied to Massachusetts streams. To meet these needs, the U.S. Geological Survey (USGS), in cooperation with the MDCR, began a study in October 2000 in southern New England to characterize streamflow at long-term streamflow-gaging stations that measure natural or minimally altered flows (index stations), and to evaluate the streamflows needed to provide habitat in riffles near selected index stations. The results of this study will facilitate the development of instream flow goals for Massachusetts by providing measures of the variability of streamflows at index stations and by relating streamflow requirements needed to sustain habitat in critical riffle habitats to streamflow statistics and flow durations at the index stations.

\section{Purpose and Scope}

This report provides:

1. flow-duration and low-flow statistics computed for a common period of record (1976-2000) for 23 index stations in Massachusetts, Rhode Island, Connecticut, and New Hampshire;

2. an assessment of fish-community composition for reaches near index stations in Massachusetts by use of fishpopulation surveys conducted by the Massachusetts Division of Fisheries and Wildlife (MDFW) and habitatuse classifications as modified from Bain and Meixler (2000);

3. flow-management targets and streamflow requirements for habitat protection for the index stations, computed by use of three methods based on hydrologic records: the Range of Variability Approach (RVA) (Richter and others, 1997), the Tennant method (Tennant, 1976), and the New England Aquatic-Base-Flow (ABF) method (U.S. Fish and Wildlife Service, 1981; Lang, 1999);

4. streamflow requirements for habitat protection computed for 10 index stations by use of 2 hydraulic-rating methods, the Wetted-Perimeter method (Nelson, 1984; Leathe and Nelson, 1986; Lohr, 1993), and the R2Cross method (Espegren, 1996, 1998; Nehring, 1979); and

5. evaluation of streamflow requirements determined by the various methods by comparison to flow statistics from the index stations.

\section{Description of Study Area}

The study area (fig. 1) in southern New England includes Massachusetts and portions of the states of Connecticut, New Hampshire, and Rhode Island. The eastern portion of the area is in the Coastal Lowland physiographic province of New England (Denny, 1982) and is characterized by low relief and low stream gradients. Topography ranges from flat terrain to low rounded hills. The central portion of the study area is in the Central Highlands, a region of moderate relief composed of broad valleys, hills, and low mountains (Denny, 1982). The broad Connecticut Valley borders the central highlands to the west. The valley, which narrows northward from Connecticut across Massachusetts, is bordered by hills. The western portion of the study area, called the Hudson Highlands by Denny (1982), has the greatest topographic relief. This area includes the Berkshire Hills, the Taconic Highlands, and the Vermont Valley. Most of the hills and valleys in the study area are oriented from north to south. Altitudes range from sea level near the coast to more than 3,900 ft at Mount Greylock in northwestern Massachusetts. 


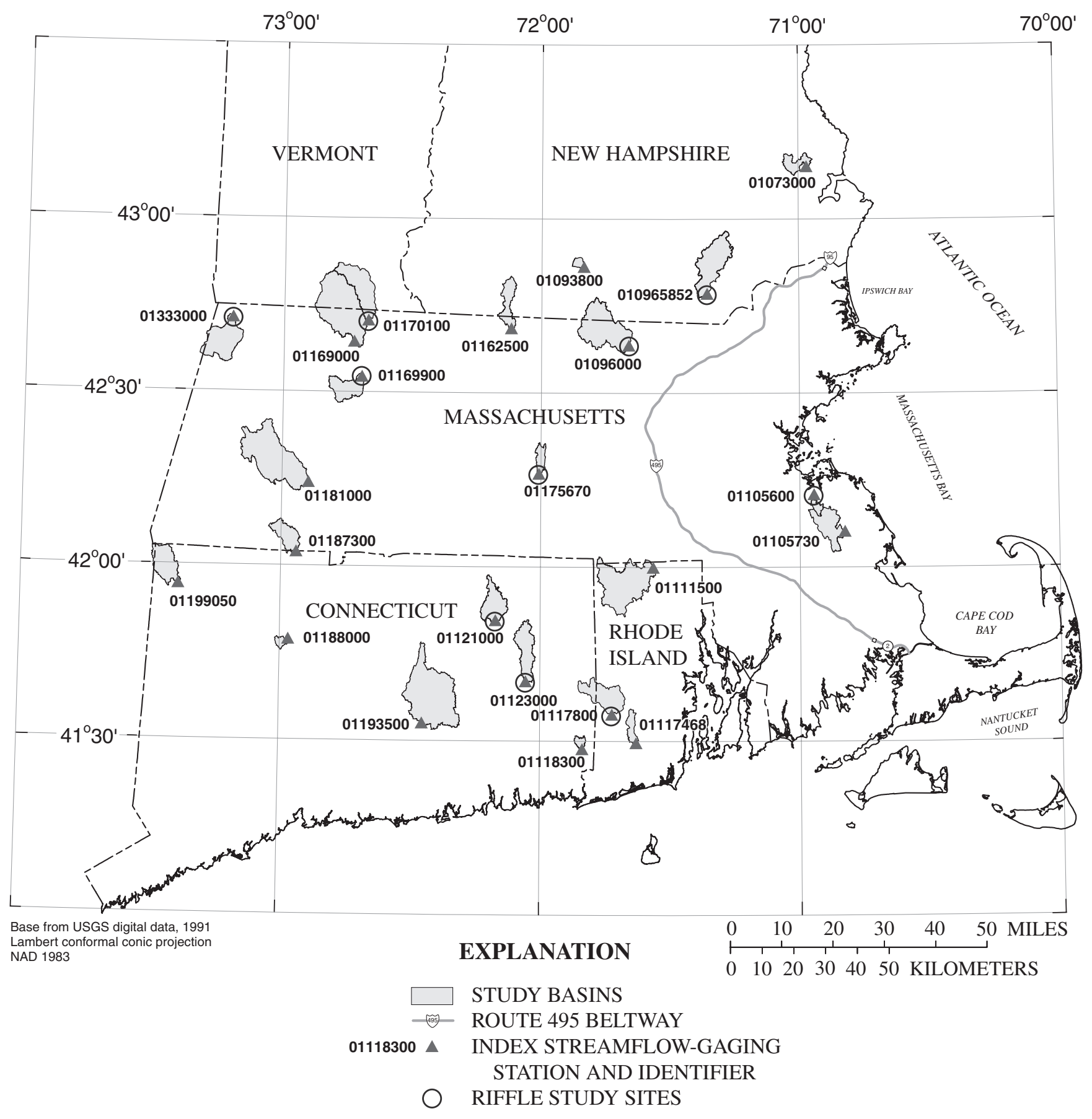

Figure 1. Location of index stations and riffle study sites, southern New England. 


\section{Streamflow Requirements and Streamflow Characteristics at Index Stations in Southern New England}

Differences in surficial geology can have a large effect on low flows. Glaciation modified the topography and drainage patterns in southern New England and left much of the bedrock covered with deposits of till and stratified drift (Randall, 2001). In general, bedrock in upland areas is covered with till, which is an unsorted mixture of clay, silt, sand and gravel, and boulders. These till deposits may be discontinuous in some areas. The low hydraulic conductivity and low storage of till and bedrock typically result in streams that have rapid runoff rates and low base flows. Many river valleys are filled with outwash sands and gravels or areas of fine- and coarse-grained glacial-lake deposits. The thickness of these sand and gravel deposits differs locally. In a few areas along the Coastal Plain, the entire landscape is covered by sand and gravel outwash. The high hydraulic conductivity and storage of sand and gravel typically result in streams that have slower runoff rates and higher base flows. Base flows may also be higher in the carbonate bedrock areas of western Massachusetts and Connecticut (Bent, 1998).

The climate of Massachusetts and southern New England is temperate, with a large range of diurnal and annual temperatures and distinct seasons. Seasonal conditions differ from place to place and between years. Climate data for a given month or season will vary over the years, but a typical month or season tends to be the exception rather than the rule (DupignyGiroux, 2003; Zielinski and Keim, 2003). Climate near the coast is influenced by proximity to the Atlantic Ocean and Long Island Sound, which influence precipitation and modify summer and winter temperature extremes. Climate in the northwestern portion of the study area is generally beyond influence from the coast. Most of the precipitation patterns in interior areas are generated by frontal systems that move from west to east. Average annual precipitation in the study area ranges from about 40 to $50 \mathrm{in} / \mathrm{yr}$ and is fairly evenly distributed across the region and equally distributed throughout the year (Gadoury and Wandle, 1986; Hammond and Cotton, 1986; Johnston, 1986; Weiss and Cervione, 1986). Precipitation is highest in the high elevation areas in western Massachusetts and southern Vermont (48 to 50 in.), and in southeastern Connecticut, Rhode Island and southeastern Massachusetts (48 to 50 in.), and is lowest in the interior of Massachusetts and in southern New Hampshire (40 to 48 in.) (Randall, 1996). Although prolonged droughts and widespread floods are infrequent, precipitation in a given month can vary considerably from year to year.

Streamflow differs seasonally, from year to year, and between regions. Stream runoff, a measure of flow that eliminates drainage area as a variable, is a useful measure to compare streamflows between regions (Leopold, 1994). Annual runoff is highest in the mountainous northwestern corner of Massachusetts (28 to 30 in.), southern Vermont (30 to 40 in.), and central Rhode Island ( 28 to 30 in.). It is lowest on Cape Cod (20 in.), and averages 22-26 in. in southern New Hampshire and in the interior and southeast portion of Massachusetts (Randall, 1996). Streamflow varies significantly through the seasons. Typically, runoff is lowest in July, August, and September because of increased evapotranspiration and depletion of soil moisture, and increases in October and November as evapotranspiration declines and soil moisture increases (Gadoury and Wandle, 1986). In southern and coastal areas, where snowfall accumulations are less, runoff continues to increase from December, January, and February, and peaks in March. In interior areas, runoff increases from October through December and declines in January and February because precipitation remains on the ground as snow. Annual spring runoff in the interior is highest in April as a result of the melting snowpack and concurrent precipitation. Spring runoff declines from March or April through June (Gadoury and Wandle, 1986). Peaks in streamflow at other times of the year can be caused by intense rainstorms, storms of long duration, winter ice jams, or hurricanes.

Southern New England is a mosaic of forested, urban, and agricultural land that reflects the history of settlement in the region. Coastal areas and river valleys were settled first, and the landscape was progressively cleared and broken up into small farms and closely spaced town centers (Zimmerman and others, 1996). Small dams and impoundments were built on many rivers in southern New England to power sawmills and gristmills. By 1870, more than half the land was cleared of forest (Flanagan and others, 1998). During the industrial revolution in the late $1800 \mathrm{~s}$, manufacturing industries that required water power became established along New England's major rivers. As the population in these mill towns grew, upland farms were abandoned and began to revert back to woodland. Growth centered in large metropolitan areas during the mid1900s, and land use in surrounding areas changed from rural to suburban (Zimmerman and others, 1996). Woodland and agricultural lands have become increasingly fragmented in the 20 th and 21 st century by the expansion of suburban areas. The eastern and southern portions of southern New England are the most urbanized, with land use in the southeastern coastal basins of southern New England about 52 percent forested, 33 percent urban, and 5 percent agriculture (Flanagan and others, 1998); in the lower Connecticut basin, about 69 percent forested and 12 percent urban (Zimmerman and others, 1996); and in the Merrimack Basin, about 75 percent forested, 13 percent urban, and 6 percent agriculture (Flanagan and others, 1998). Land-use changes can affect low flow characteristics of streams. If large areas of a basin are covered by impervious surfaces, such as roads, buildings, and parking lots, the increase in storm runoff and reduced infiltration will decrease base flows.

\section{Previous Studies}

The USGS began a study in 1995 to determine the spatial distribution and correlation among parameters related to aquatic habitats and flow conditions of Massachusetts streams. The study, done in cooperation with the Massachusetts Department of Environmental Management, Office of Water Resources (currently the MDCR), and the Massachusetts Department of Environmental Protection (MADEP), evaluated median daily mean flows for August (Ries, 1997) and wetted-perimeter 
measures at streamflow-gaging stations (Mackey and others, 1998). Additional studies reported low-flow statistics and used regression analysis to regionalize low-flow frequency statistics for Massachusetts streams (Ries and Friesz, 2000; Ries and others, 2000). In 1998-99 the USGS and MDFW investigated relations among stream habitat, fish communities, and hydrologic conditions in the Ipswich River basin in northeastern Massachusetts (Armstrong and others, 2001) in conjunction with a basin-scale precipitation-runoff model with the Hydrologic Simulation Program-Fortran (HSPF) (Zarriello and Ries, 2000). Methods for determining streamflow requirements for habitat protection that were used in the Ipswich basin have also been applied to the Usquepaug-Queen basin in Rhode Island (Armstrong and Parker, 2003), and to the Charles and Assabet Rivers in Massachusetts (Parker and Armstrong, 2001).

\section{Relations among Flow Regimes, Stream Processes, and Aquatic Habitat}

Flow regime, along with basin topography, and bedrock and surficial geology, is one of the dominant variables that determines the form and function of a river and ultimately, the integrity of river ecosystems (Poff and others, 1997; Instream Flow Council, 2002; Molnar and others, 2002). In a natural flow regime, the magnitudes of flows vary seasonally and these seasonal flows, floods, and droughts also vary between wet and dry years (Richter and others, 1996; Olden and Poff, 2003; Postel and Richter, 2003). These variations in flow create and maintain a wide range of habitat features and regulate geomorphic and ecological processes that are critical to the abundance and diversity of fish and other aquatic life and the overall ecological integrity of rivers. The riverine landscape is in a state of constant adjustment to the natural sequence of disturbances and recovery created by variations in flow such as floods and droughts (Beschta and Platts, 1986; Petts and Calow, 1996; Molnar and others, 2002). Floods and overbank flows form and maintain channel, flood plain, and valley features and alter riparian habitat (Leopold, Wolman, and Miller, 1964; Hill and others, 1991). These high flows also enable fish to spawn on flood plains, and provide migration and spawning cues for fish (Postel and Richter, 2003). Intermediate flows that are near bankfull mobilize streambed sediment, restore and enhance aquatic habitat, maintain active channel width, and keep stream banks and channels functioning. Moderate flows provide diverse habitat in riffles, pools, and runs; provide important cover, nesting, spawning, and rearing habitat (Leonard and Orth, 1988; Aadland, 1993); and restore water quality after prolonged low flows (Postel and Richter, 2003). Low flows in a natural flow regime provide adequate habitat space for fish and other aquatic organisms during summer low-flow periods (Hill and others, 1991; Kondolf and Wilcock, 1996).

Modification of streamflow, such as by water withdrawal, diversion, impoundment, or storage and release, is one of the most widespread disturbances of stream environments (Ward and Stanford, 1983; Bain and others, 1988). Alteration of flow regimes can be a significant factor in the decline of fish populations (Bauer and Ralph, 2001). The effects of flow modification can devastate the aquatic communities of headwater streams and streams with small drainage basins (Simon, 1999). Water withdrawals or regulation that cause streamflows to be maintained at a minimum level over an extended period of time can be detrimental to a river's ecosystem (Instream Flow Council, 2002). A single minimumflow requirement cannot meet the needs of all species or maintain biologic diversity and dynamic ecosytem functions (Stalnaker, 1990).

Maintenance of streamflow variability throughout the year and between years is important for a healthy ecosystem (Hill and others, 1991; Poff and others, 1998). Many aquatic species have life cycles that are, in part, adapted to the seasonal timing of streamflows. Predictable high and low streamflows provide cues for certain life-cycle events, such as fish feeding and spawning movements, egg hatching, rearing, movement into and out of flood-plain areas, and upstream and downstream movements. Some species do better during high flows, others during low flows. A natural flow regime varies in the magnitude, frequency, duration, timing, and rate of change of streamflow. Given a natural flow regime, the needs of all river species are met over the courses of seasons, years, decades, and centuries (Postel and Richter, 2003). Poff and others (1998) suggest that the native biodiversity and integrity of river ecosystems can be sustained by the maintenance of the natural flow regime that created that diversity.

\section{Acknowledgments}

The authors are grateful to the MDCR, MDFW, and other public agencies, private organizations, and individuals who provided assistance, guidance, and information during the study, and in particular to Victoria Gartland, MDCR, and members of the MWRC and the Streamflow and Habitat Workgroup, who encouraged this study. The cooperation of public and private landowners who granted permission to access the rivers, is appreciated.

\section{Streamflow Characteristics at Index Streamflow-Gaging Stations in Southern New England}

Streamflow statistics for index streamflow-gaging stations were used to characterize streamflows of rivers in southern New England. The rivers used in this study were determined to have the least altered streamflows from among the set of rivers in southern New England that have long-term stations that meet the selection criteria described below. Because of current and historic effects of human alterations to rivers, none of the rivers 


\section{Streamflow Requirements and Streamflow Characteristics at Index Stations in Southern New England}

used in this study can be assumed to have completely natural or unaltered streamflows, or to have fish communities resembling those in pre-colonial times. Several of the stations used in this study are in rapidly developing areas, and because of changing land-use conditions and the associated potential for flow modifications and water withdrawals, may no longer meet the criteria for use as index stations in the near future.

\section{Index Stations}

Streamflow records from 23 active streamflow-gaging stations in southern New England were used to develop a database for determination of flow-duration and low-flowfrequency statistics. The index stations include 10 from Massachusetts, 7 from Connecticut, 3 from New Hampshire, and 3 from Rhode Island (table 1).

\section{Selection Criteria}

Streamflow-gaging stations were selected according to the following criteria: (1) stations are active as of 2002; (2) the station has produced a minimum of 25 years of continuous, good-quality streamflow data; (3) the station's record indicates minimal effects from surface-water regulation, such as diversion, and augmentation of streamflow, or from the reduction of base flow due to ground-water pumping; and (4) the station's drainage area is between 3 and $100 \mathrm{mi}^{2}$.

The initial selection of streamflow-gaging stations was from those used for the Hydro-Climatic Data Network (HCDN) (Slack and Landwehr, 1992). Few index stations were initially identified in eastern Massachusetts because of surface- and ground-water withdrawals, streamflow regulation, interbasin transfers, and the effects of extensive suburban and urban land use on streamflow. Consequently, the study area was expanded to adjacent states in southern New England to include index stations on nearby rivers that met the selection criteria. Additional streamflow-gaging stations were selected from among those used in low-flow investigations (Ries and Friesz, 2000) and through consultation with officials from the USGS and from state agencies in New England.

To improve the distribution of index stations, two streamflow-gaging stations that did not meet the selection criteria for 25 years of record were included in the study. Streamflow records for Wood River near Arcadia, RI (01117800), and Beaver Brook at North Pelham, NH (010965852), were estimated to fill in missing daily mean streamflow to extend the record at these stations to the 25-year period of analysis.

\section{Basin Characteristics}

The values for contributing drainage area, percent sand and gravel, basin slope, and basin elevation were determined for the 23 index stations with a geographic information system (GIS) to assist in classification of groups of stations with similar flow characteristics. These four basin characteristics were selected because they had been used in regression equations developed for estimating low-flow statistics for Massachusetts and New Hampshire streams (Ries and Friesz, 2000; Flynn, 2003). Drainage area, in square miles, is the area measured by a horizontal plane that is enclosed by the drainage divide, which was determined from USGS 1:24,000 source scale elevation data. Sand and gravel, in percent, is the areal percentage of sand and gravel in the drainage basin and was measured from a USGS 1:250,000-scale geologic map developed by Byron Stone (Massachusetts Geographic Informations System, 2001). Average basin slope, in percent, is the average slope of the drainage basin and was measured by use of a Digital Elevation Model (DEM) with the computer software ArcInfo

(Environmental Systems Research Institute, Inc., 1994). Mean basin elevation, in feet, is the mean elevation derived from the intersection of basin polygon coverages and DEMs. Except for the eastern portion of Massachusetts, which has few streamflow-gaging stations with unaltered flow, the 23 stations are well distributed throughout southern New England. The stations represent a range of basin characteristics, including drainage area (from 3.6 to $100 \mathrm{mi}^{2}$ ), percent sand and gravel (from 0.3 to 70.8 percent), basin slope (from 2.35 to 23.23 mean percent rise) and basin elevation (from 101 to $1557 \mathrm{ft}$ ).

\section{Fish-Community Sampling and Assessment}

Fish-community data used in this report were collected near 10 of the index stations in Massachusetts from September 1998 through July 2002. Fish were collected by the MDFW as part of the Statewide Fisheries Assessment Program. The fishcommunity analysis pertains only to inland, freshwater-fish communities, and, with the exception of American eel and Atlantic salmon, does not include diadromous, estuarine, or marine fish. Biological monitoring in this study targeted fish because they are long-lived and are sensitive to a wide range of stresses. In comparison to macroinvertebrates, fish are easy to identify, and the relations between fish and stream health are easier for the public to understand. In addition, streamflows adequate to maintain fisheries also tend to be sufficient to maintain macroinvertebrates and other aquatic life. A drawback of the use of fish to indicate flow degradation is that fish integrate the effects of many stresses, so it is difficult to determine the specific sources of individual stresses. Another complication is that the fish communities in Massachusetts and New England rivers naturally have a low number of species (species richness) (Halliwell and others, 1999).

\section{Methods for Sampling and Assessment of Fish} Communities-Fish-community assessment was designed to characterize fish-species diversity, relative abundance, and the length-frequency distribution of fish in the study streams (fig. 2). Fish were sampled during summer periods of low to moderate streamflow because fish assemblages during summer are generally stable and contain the full range of resident species (Gibson and others, 1996). 


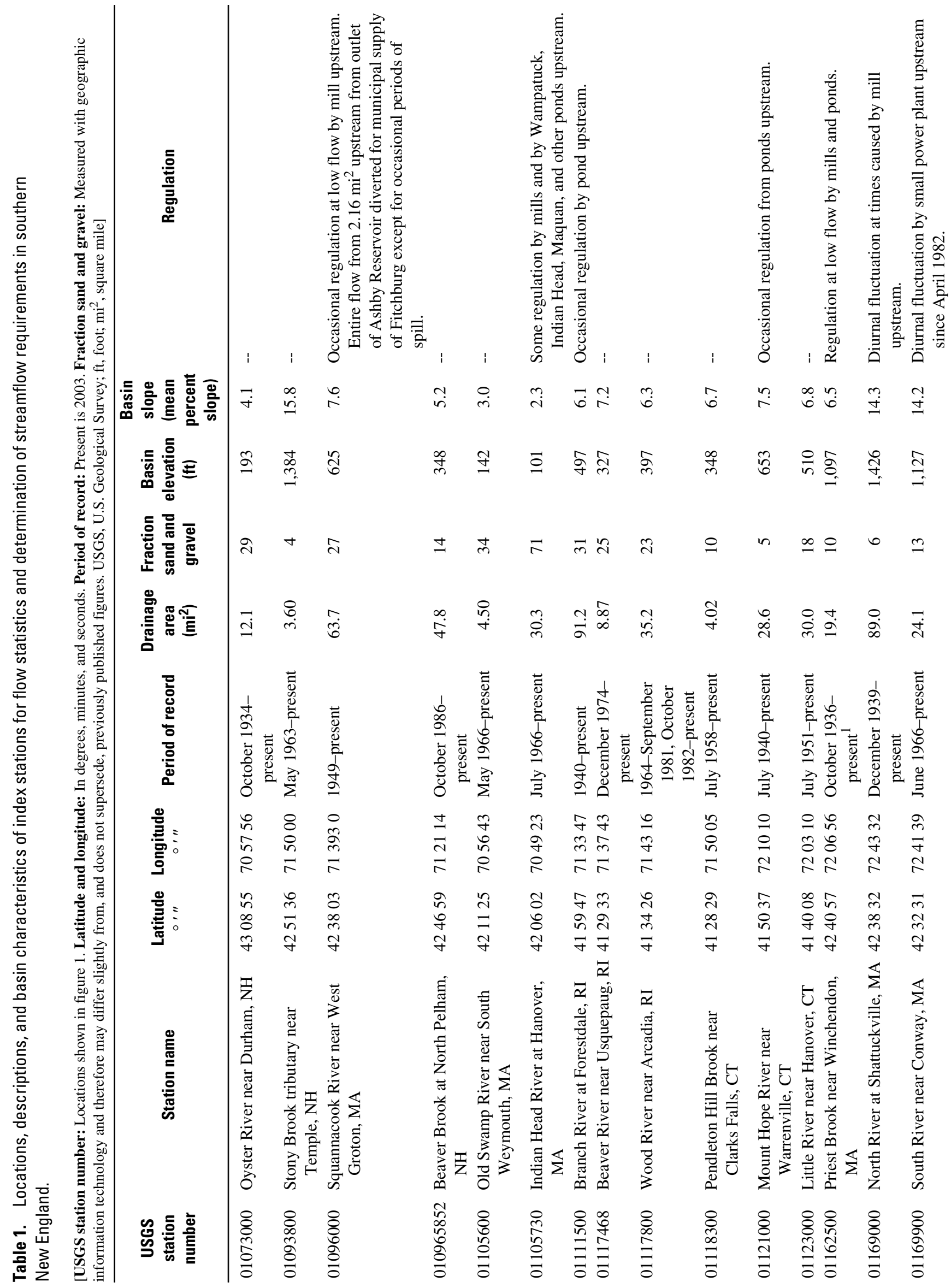




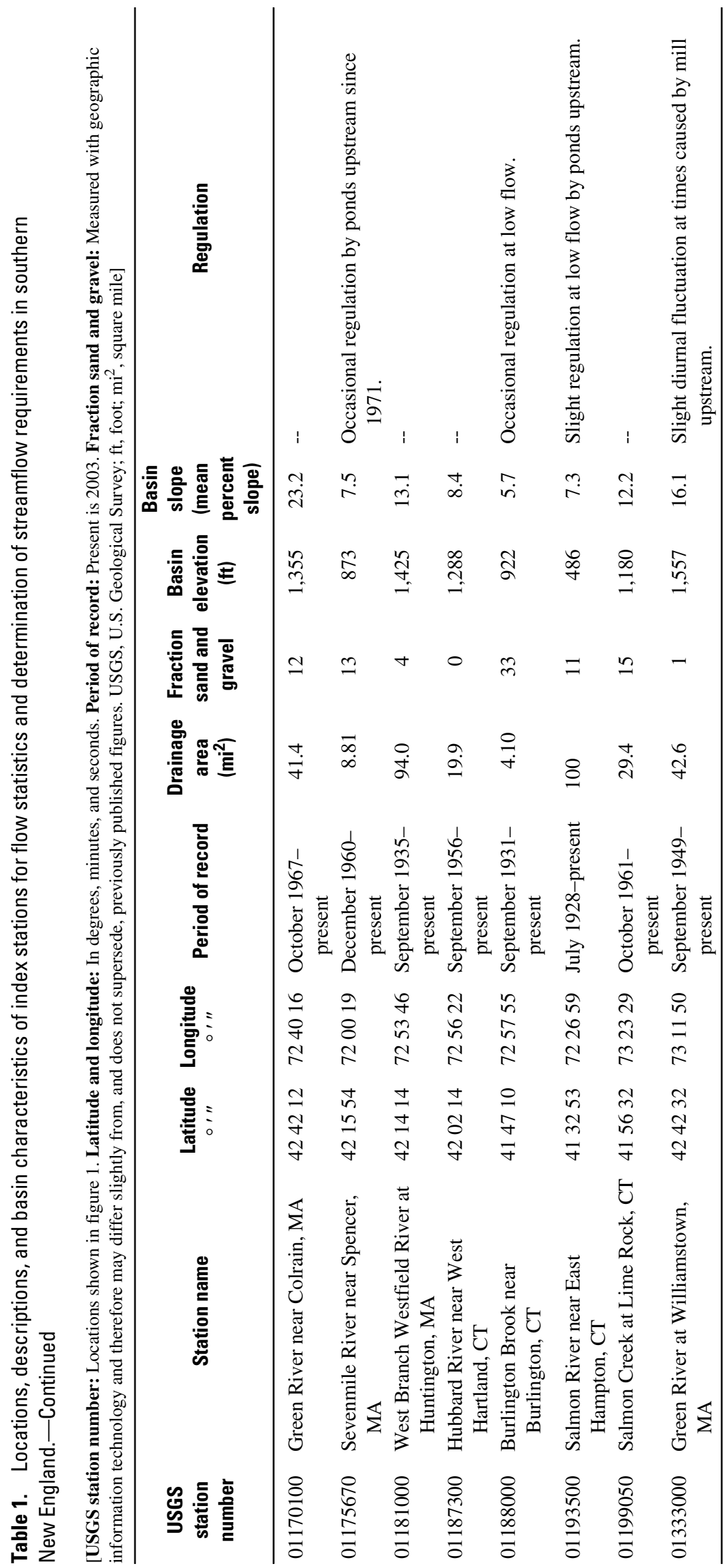




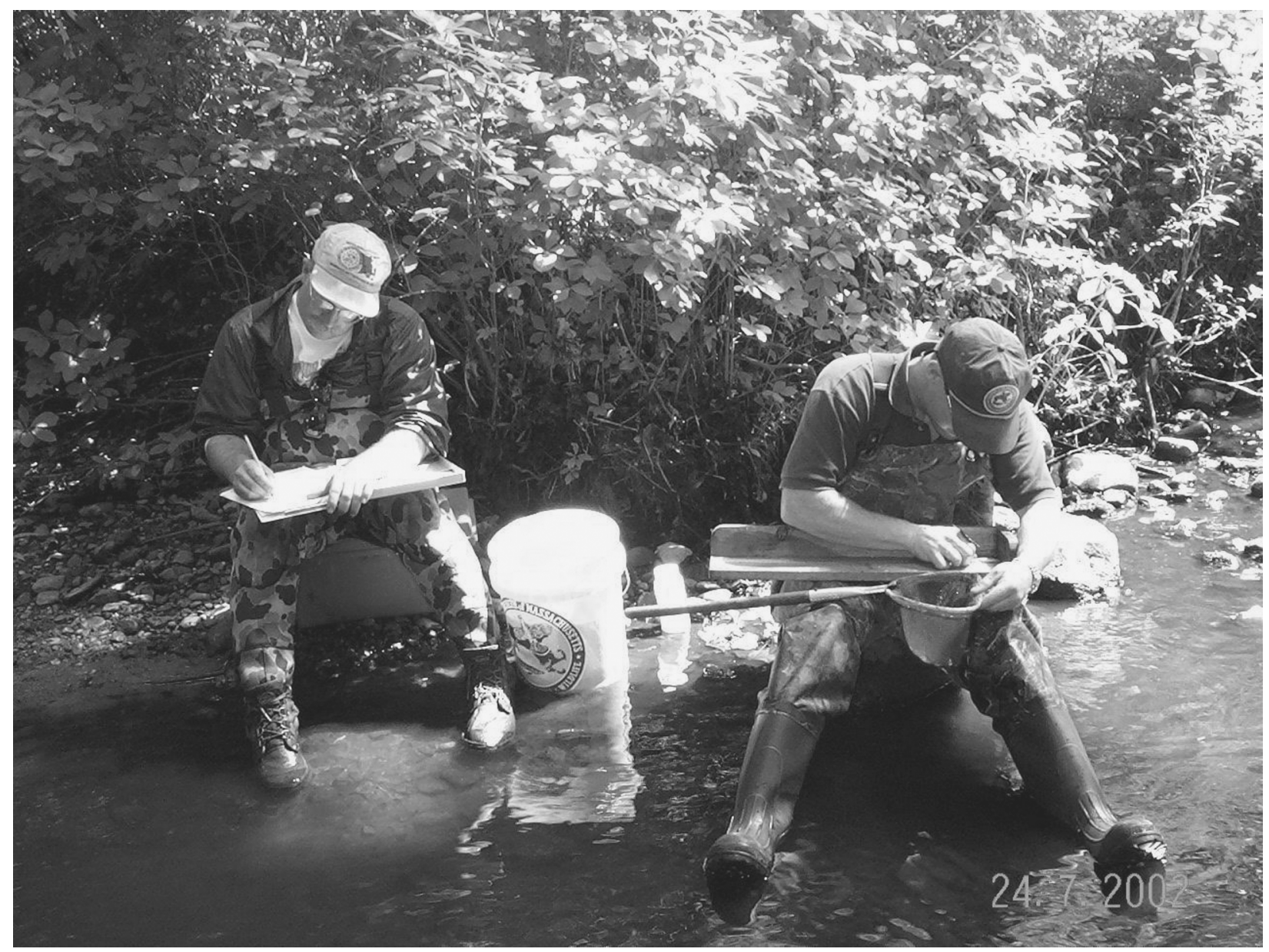

Figure 2. Massachusetts Division of Fisheries and Wildlife and U.S. Geological Survey personnel identifying, counting, and measuring fish that were collected by electrofishing.

Sampling reaches included at least $328 \mathrm{ft}$ of stream length, where possible. Fish were sampled, in a single pass of the reach, by electrofishing with pulsed direct current (DC) backpack units or barges. Backpack electrofishing units are best used in small or shallow streams and were appropriate for sampling most tributary and headwater stream reaches. Barge electrofishing units are best used in wadeable reaches where a stronger power supply and more personnel for electrofishing are required. Barge units were appropriate for sampling many of the free-flowing reaches of larger study streams.

Fish sampled in this study are classified on the basis of their habitat use (table 2), and fish communities are compared to a target fish community developed for the Quinebaug River (modified from Bain and Meixler, 2000). The Quinebaug target fish community can be used to represent the condition of a fish community in the mainstem reaches of relatively natural rivers in southern New England (table 3). Habitat-use categories developed for the Quinebaug River have been used to assess fish communities found in other river basins in Massachusetts and Rhode Island (Armstrong and others, 2001; Armstrong and Parker, 2003; G.W. Parker, U.S. Geological Survey, written commun., 2004).

Fish were classified into three classes on the basis of their habitat use: macrohabitat generalists (MG), fluvial dependents (FD), and fluvial specialists (FS) (table 2), (Bain and Knight, 1996, Bain and Meixler, 2000). Macrohabitat generalists, such as pumpkinseed and redfin pickerel, are fish species that use a broad range of habitat; they include species commonly found in lakes, reservoirs, and rivers, and can complete their life cycle in any one of these systems. Fluvial dependents, such as common shiners and white sucker, require access to streams or flowingwater habitats for a specific life stage, but otherwise can be found in lakes, reservoirs, and rivers. Fluvial specialists, such as blacknose dace and creek chubsucker, are common only to streams or rivers and require flowing-water habitats throughout their life cycle (Bain and Travnichek, 1996). 
Table 2. Scientific names and habitat-use classifications of fish in southern New England.

[Modified from Bain and Meixler, 2000. Fish Code: Massachusetts Division of Fish and Wildlife Fish Code. HUC (habitat-use classification): FD, fluvial dependent; FS, fluvial specialist; MG, macrohabitat generalist]

\begin{tabular}{|c|c|c|c|c|}
\hline $\begin{array}{l}\text { Fish } \\
\text { code }\end{array}$ & Common name & Genus & Species & HUC \\
\hline $\mathrm{AE}$ & American eel & Anguilla & rostrata & MG \\
\hline AS & Atlantic salmon & Salmo & salar & FS \\
\hline B & Bluegill & Lepomis & macrochirus & MG \\
\hline BB & Brown bullhead & Ameiurus & nebulosus & MG \\
\hline BND & Blacknosed dace & Rhinichthys & atratulus & FS \\
\hline BS & Banded sunfish & Enneacanthus & obesus & MG \\
\hline $\mathrm{BT}$ & Brown trout & Salmo & trutta & FS \\
\hline CCS & Creek chubsucker & Erimyzon & oblongus & FS \\
\hline $\mathrm{CP}$ & Chain pickerel & Esox & niger & MG \\
\hline $\mathrm{CRC}$ & Creek chub & Semotilus & atromaculatus & FS \\
\hline CS & Common shiner & Notropis & cornutus & FD \\
\hline EBT & Brook trout & Salvelinus & fontinalis & FS \\
\hline $\mathrm{F}$ & Fallfish & Semotilus & corporalis & FS \\
\hline GS & Golden shiner & Notemigonus & crysoleucas & MG \\
\hline K & Banded killifish & Fundulus & diaphanus & MG \\
\hline LMB & Largemouth bass & Micropterus & salmoides & MG \\
\hline LND & Longnose dace & Rhinicthys & cataractae & FS \\
\hline LNS & Longnose sucker & Catostomus & catostomus & FD \\
\hline $\mathrm{P}$ & Pumpkinseed & Lepomis & gibbosus & MG \\
\hline $\mathrm{RP}$ & Redfin pickerel & Esox & americanus & MG \\
\hline RT & Rainbow trout & Oncorhynchus & mykiss & FS \\
\hline $\mathrm{SC}$ & Slimy sculpin & Cottus & cognatus & FS \\
\hline SD & Swamp darter & Etheostoma & fusiforme & MG \\
\hline SL & Sea lamprey & Petromyzon & marinus & -- \\
\hline SMB & Smallmouth bass & Micropterus & dolomieu & MG \\
\hline SS & Spottail shiner & Notropis & hudsonius & MG \\
\hline TD & Tesselated darter & Etheostoma & olmstedi & FS \\
\hline WS & White sucker & Catostomus & commersoni & FD \\
\hline YB & Yellow bullhead & Ameiurus & natalis & MG \\
\hline YP & Yellow perch & Perca & flavescens & MG \\
\hline
\end{tabular}

For the purposes of this report, habitat classifications for creek chub and American eel were changed from those reported by Bain and Meixler (2000) to accommodate regional differences in habitat requirements for fish in Massachusetts. Atlantic salmon and longnose sucker, which were not classified in Bain and Meixler (2000), were categorized as fluvial dependents or fluvial specialists. American eel, a catadromous fish that requires access to streams habitats for a portion of its life cycle, was reclassified as a macrohabitat generalist because it occupies a wide range of habitats during the portion of its life cycle in freshwater streams. Some stocked brook, brown, or rainbow trout, indistinguishable at intermediate sizes from wild fish, are likely included, but are a small proportion of the fluvial specialists from any one stream.

Recent work by the MDFW (T.A. Richards, Massachusetts Division of Fisheries and Wildlife, written commun., 2003) established that the proportion of fluvial fish in undisturbed small streams or headwater tributaries typically exceeds that of the target fish community developed for the mainstem reaches of relatively natural rivers in southern New England. Even in rivers with varying degrees of flow alterations, such as those shown in table 3 , the proportion of fluvial fish in tributaries typically exceeds that in mainstem reaches.

Fish-Community Assessment-From 1998 to 2002, 2,605 fish of 30 different species and 2 hybrids were collected at free-flowing sites near 10 of the index stations in Massachusetts (table 4). A total of 19 sites were sampled. The number of fish captured at a site ranged from 3 to 410 and the number of species ranged from 2 to 11 . Backpack electroshocking was used at 17 sites with a total of $6,083 \mathrm{ft}$ of stream sampled. Sample reach lengths ranged from 98 to $722 \mathrm{ft}$. Barge electroshocking was used at two sites with a total of $1,322 \mathrm{ft}$ of stream sampled.

Fish communities from a range of habitat types were assessed to characterize fish-species diversity, relative abundance, and length frequency distribution in the study streams (table 5). The percent of macrohabitat generalists in the study streams averaged 24 percent and ranged from 0 percent (Green River near Colrain) to 100 percent (Old Swamp River). The range was highly dichotomous, with the Old Swamp River, Indian Head River, and Priest Brook composed of 100 percent, 75 percent and 43 percent macrohabitat generalists, respectively, (average of 73 percent) and the rest of the sites ranging from 0 percent to 12 percent macrohabitat generalists (average of 3 percent). Most of the fish communities sampled for this project had populations with a high percentage of fluvial species. The relatively unaltered flow conditions at these sites were assumed to be one factor that has contributed to this condition. These findings support the use of these stations as index stations.

\section{Flow Statistics for Index Stations}

Low-flow statistics derived from long-term streamflow data can vary depending on the time period selected because of short- and long-term changes in climate. The longer the period selected for analysis, the more representative the flow statistics will be of long-term climate conditions at the station (Bent, 1995) if the basin has remained generally unchanged. 
Table 3. Percentages of fish in each habitat-use classification sampled in flowing reaches of several river basins in Massachusetts.

$[--$, target percentage has not been developed]

\begin{tabular}{|c|c|c|c|c|c|c|c|c|c|}
\hline \multirow{2}{*}{ Habitat-use classification } & \multicolumn{9}{|c|}{ Watershed } \\
\hline & Quinebaug & Westfield & Shawsheen & Blackstone & Nashua & Assabet & Charles & Housatonic & Ipswich \\
\hline \multicolumn{10}{|c|}{ Mainstem sites ${ }^{1}$} \\
\hline Fluvial dependent & 36.2 & 28 & 1.2 & 58.8 & 32.0 & 23.7 & 1.7 & 12.9 & 1.5 \\
\hline Fluvial specialist & 27.4 & 49.9 & 6.7 & 5.1 & 37.8 & 25.9 & .2 & 17.0 & 1.5 \\
\hline Fluvial dependent & 25 & -- & -- & -- & -- & -- & -- & -- & -- \\
\hline Fluvial specialist & 50 & -- & -- & -- & -- & -- & -- & -- & -- \\
\hline \multicolumn{10}{|c|}{ Tributary sites $^{3}$} \\
\hline Macrohabitat generalist & 8.4 & 4.6 & 70.4 & 24.4 & 8.1 & 49.4 & 87.5 & 13.6 & 75.9 \\
\hline
\end{tabular}

Flow statistics typically are calculated for the period of record at a streamflow-gaging station. However, concurrent records of equal length are best for a regional analysis (Fennessey and Vogel, 1990). A period of record of at least 20 years is commonly used to ensure stable estimates of streamflow predictability. For this report, monthly flow durations were calculated for a 25 -year period for water years ${ }^{1} 1976-2000$ for each of the streamflow-gaging stations evaluated in this study. A 25-year time period was used primarily to meet criteria for use of the New England Aquatic-Base-Flow method (U.S. Fish and Wildlife Service, 1981) and to assure that the index gages represented current land-use conditions. The 25 -year period was also selected to avoid extending streamflow records for one of the index stations (Beaver Brook, $\mathrm{NH}$ ) for a longer period than the period of record at the station.

Streamflow records for the streamflow-gaging station Wood River near Arcadia, RI (01117800), were estimated to fill in missing daily streamflows from October 1, 1981, to September 30, 1982, and discharge records for the streamflow-gaging station Beaver Brook at North Pelham, NH (010965852), were extended back ten years from October 1986 to October 1976. Streamflow records for Wood River (01117800) and Beaver Brook (010965852) were extended by using streamflow records and durations from Little River near Hanover, CT (01123000), and Squannacook River near West Groton, MA, respectively. Missing streamflow records were

\footnotetext{
${ }^{1} \mathrm{~A}$ water year is the 12 -month period beginning October 1 and ending September 30 of the following year. It is designated by the calander year in which it ends.
}

estimated by use of a modification of the QPPQ transform method (Fennessey, 1996). This method estimates missing record for a streamflow-gaging station from records at a nearby station. Streamflow gaging stations similar in size, geology, topography, and climate were tested for use in estimating streamflow record, and the station with the highest correlation coefficient for daily flow durations for the common period of record between the stations was selected to estimate the missing record. The QPPQ transform method is based on the assumption that daily flows at the stations have the same flow duration. First, flow durations for daily discharges for each day of the missing record are determined from the nearby streamflowgaging station. These flow durations are then used, together with the existing flow-duration curve from the station with missing record, to calculate a time-series of daily discharge values for the period of missing record.

\section{Flow-Duration Statistics}

A flow-duration curve is a cumulative frequency plot that shows the percentage of time a daily mean flow is equaled or exceeded during a given period (Gordon and others, 1992). For example, the 98-percent-duration flow $\left(\mathrm{Q}_{98}\right)$, considered a low flow, is equaled or exceeded 98 percent of the time, and the 2percent-duration flow $\left(\mathrm{Q}_{2}\right)$, considered a high flow, is equaled or exceeded only 2 percent of the time. Streamflows plotted on a flow-duration curve do not show how daily streamflows respond to meteorological events or seasonal weather patterns, but they do provide quantitative information about the overall streamflow at a station. 

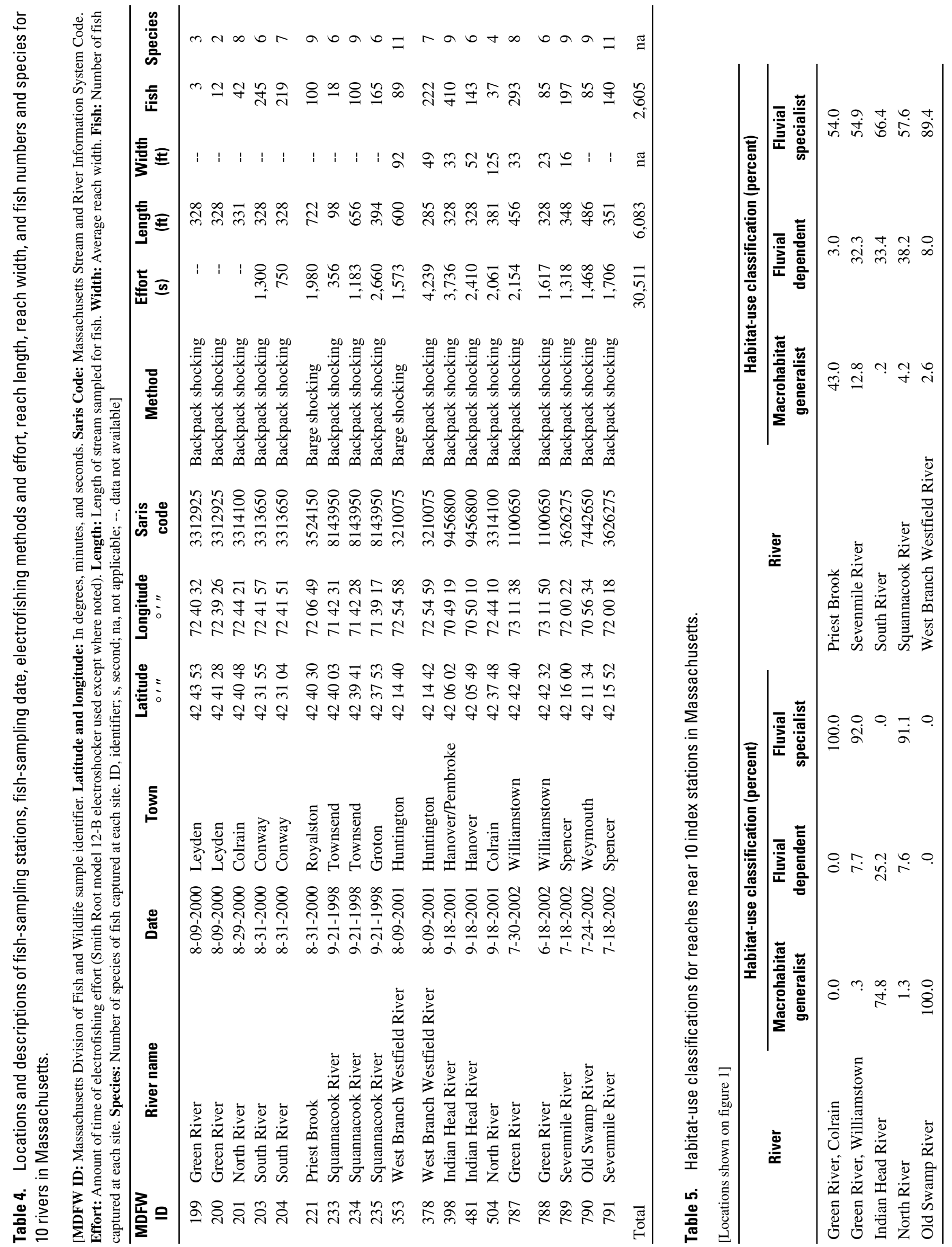
Annual Flow-Duration Statistics-Annual flowduration curves show the relation between streamflow and the percentage of time streamflow is exceeded on an annual basis. Annual flow-duration curves for a station were constructed for this report by ranking daily mean discharges for the period of analysis from largest to smallest and assigning the flows a plotting position by using the Weibull formula (Helsel and Hirsch, 1992). The probability that each discharge is equaled or exceeded was determined. A curve drawn through the plotted discharges and probabilities represents the percentage of time that streamflows were equaled or exceeded over the selected period.

The shape of flow-duration curves is determined by the hydrologic and geologic characteristics of a basin. The curves may be used to compare the characteristics of different basins. A curve with a steep slope at the high-flow end indicates a flashy river where flow is largely from direct runoff. A curve with a gentle slope at the low-flow end indicates a river that is dominated by base flow from ground-water discharge or surface storage (such as by lakes or wetlands) (Gordon and others, 1992). Annual flow-duration curves were prepared from stream discharge data for a 25-year period (1976-2000) for each of the index stations. The curves for two stations, Wood River near Arcadia, RI (01117800), and Green River at Williamstown, MA (01333000), are compared in fig. 3 to illustrate the effect of differing geologic characteristics on the shape of flow-duration curves. The contributing area for Wood River has a high percentage of sand and gravel, whereas the contributing area for Green River is predominantly composed of till and bedrock.

Annual flow-duration curves for 10 of the index stations used later in the report for analysis of streamflow requirements determined by use of the Wetted-Perimeter and R2Cross methods are included in Appendix 1. Annual flow-duration curves for the additional 13 index stations are available for inspection in the Massachusetts District office, Northborough, MA. Annual flow-duration statistics are compared to streamflow requirements for habitat protection in the second half of this report.

Monthly Flow-Duration Statistics-Although flowduration curves are traditionally constructed on an annual basis (Searcy, 1959), flow-duration curves are not restricted solely to the use of an annual time period. Monthly flow-duration plots can also be constructed. The variability in the magnitude and frequency of daily streamflows at a station within different months of the year and between wet and dry years can be characterized by analysis of monthly flow-duration curves (Vogel and Fennessey, 1994). Monthly flow-duration curves were prepared for this report from daily mean streamflows for each month of each year between 1976 and 2000. The distribution of selected flow durations were then calculated to characterize streamflow variability over the 25 -year period.

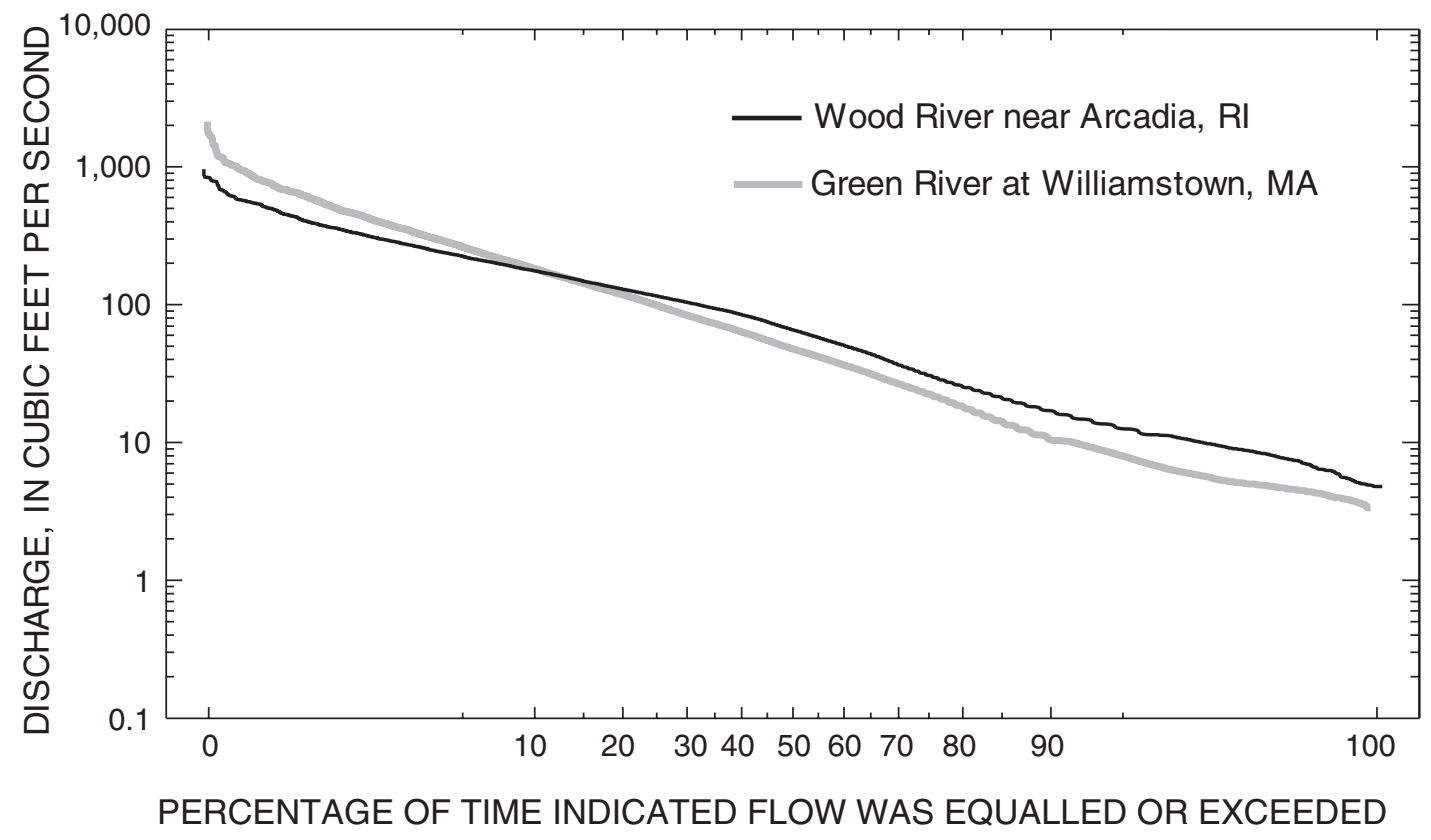

Figure 3. Annual flow-duration curves for Wood River near Arcadia, RI (01117800), and Green River at Williamstown, MA (01333000), for water years 1976-2000. 


\section{Streamflow Requirements and Streamflow Characteristics at Index Stations in Southern New England}

To construct monthly flow-duration curves for this report, daily mean streamflow data for a streamflow-gaging station were downloaded by use of the USGS data base NWIS (National Water Information System). Monthly flow durations were calculated for each month of the year for each of the 25 years from 1976-2000 by use of a Visual Basic program (R.W. Dudley, U.S. Geological Survey, written commun., 2003) in which the daily mean streamflows for each day of a given month of a given year were ranked in ascending order of discharge and the exceedance probability of each streamflow was calculated by use of the Weibull formula (Helsel and Hirsch, 1992). One limitation of constructing a monthly flowduration curve is that each month has only 28 to 31 days. Therefore, each daily discharge represents 3.2 to 3.5 percent of the monthly dataset. Consequently, due to precision limitations, monthly flow durations below the 5-percent monthly flow duration and above the 95-percent monthly flow duration were not determined for this report.

Monthly flow-duration curves show the distribution of streamflows within a given month for a given year. A 50percent monthly flow duration $\left(Q_{50}\right)$ is a measure of the central tendency of all flow for a given month. The $\mathrm{Q}_{50}$ is the flow exceeded 50 percent of the time during the month of interest for that year. Other monthly flow durations can be used to show the variability of daily flows within a month. The 75-percent monthly flow duration $\left(\mathrm{Q}_{75}\right)$ is a low flow that is exceeded 75 percent of the time during the month. The 25-percent monthly flow duration $\left(\mathrm{Q}_{25}\right)$ is a high flow that is exceeded 25 percent of the time during the month. For a given month, 50 percent of the daily mean flows fall between the $\mathrm{Q}_{75}$ and $\mathrm{Q}_{25}$ discharges.

The magnitude of monthly flow durations varies from year to year. The variability of any individual monthly flow duration between years can be characterized by use of nonparametric statistics. The distribution of a selected flow duration over the 25 year study period was determined by use of an Excel spreadsheet, in which the 25 discharges for a selected monthly flow duration (one for each year between 1976 and 2000) were ranked in ascending order of discharge, and a percentile was calculated from the cumulative distribution frequency position of the sorted data. The 50th percentile of a monthly flow duration is the median value for that monthly flow duration for a given period of years. The 75 th percentile of a monthly flow duration means that 75 percent of the flows for that flow duration are lower than or equal to that flow, for the period analyzed. Similarly, the 25 th percentile of a monthly flow duration means that 25 percent of the flows for that flow duration are lower than or equal to that flow, for the period analyzed. These percentiles also can be used to express confidence limits around a given flow duration. For example, the range between the 25 th and 75 th percentiles of monthly flow duration, or interquartile range (IQR), represents the 50-percent confidence interval for that monthly flow duration, and the range between the 95th and 5th percentiles represents the 90percent confidence interval for that flow duration.

A monthly flow-duration analysis was conducted for each index station for each month of each year over a 25 -year period (1976-2000). Records for the streamflow-gaging station on the Sevenmile River (01175670) are used to illustrate how monthly flow-duration curves can be used to describe streamflow variability (fig. 4). Three hydrographs were prepared to show daily flows in August during years when median monthly flows were dry (1977), median (1978), and wet (1990) (fig. 4A). Dry, median, and wet Augusts were identified when the August $\mathrm{Q}_{50}$ for that year was equivalent to the 75th, 50th, and 25th percentile discharges for the median $\mathrm{Q}_{50}$ for August for the period between 1976-2000, respectively. The hydrographs show several peaks in August streamflows in response to storm events. Some years, such as 1990, may have several peaks, and other years, such as 1977, may have only one. The monthly flow-duration curves for August for 1977, 1978, and 2000 are shown in figure $4 B$. The magnitudes of the $\mathrm{Q}_{50}$ flows for August differ between dry, median, and wet years. The shapes of the monthly flow-duration curves for other flow durations during the month are not necessarily parallel for individual years. Differences in the magnitudes of individual flow durations occur because storm events and antecedent conditions are different from year to year. Therefore, the $\mathrm{Q}_{50}$ may not represent conditions for the whole month. For example, for the 3 years shown, the year that had the highest daily flow in August (1977) also had the lowest daily flow. Consequently, the flow-duration curves cross at the higher duration flows. The median flow durations for the 1976-2000 period are shown in figure $4 C$. The median $\mathrm{Q}_{25}$ and median $\mathrm{Q}_{75}$ discharges illustrate how flow varies within the month for an average year. The 75 th and 25th percentiles for the median $\mathrm{Q}_{50}$ illustrate how the median flow varies between years. For example the bar at the $\mathrm{Q}_{50}$ between the 75th and 25th percentiles on figure $4 C$ is the IQR for the median $\mathrm{Q}_{50}$ for the 1976-2000 period. These 75th and 25th percentiles at the $\mathrm{Q}_{50}$ represent wet and dry Augusts as illustrated in figure $4 B$ by the August monthly duration curves for 1990 and 1977. Similar percentile ranges could also be determined for other flow durations to evaluate how flows other than the median varied from year to year.

The median streamflow at the 50-percent monthly flow duration (median $\mathrm{Q}_{50}$ ) and the IQR for the $\mathrm{Q}_{50}$ for each of the 23 index stations, normalized by drainage area, are shown in table 6. The IQR represents the 50-percent confidence interval for the $\mathrm{Q}_{50}$. 

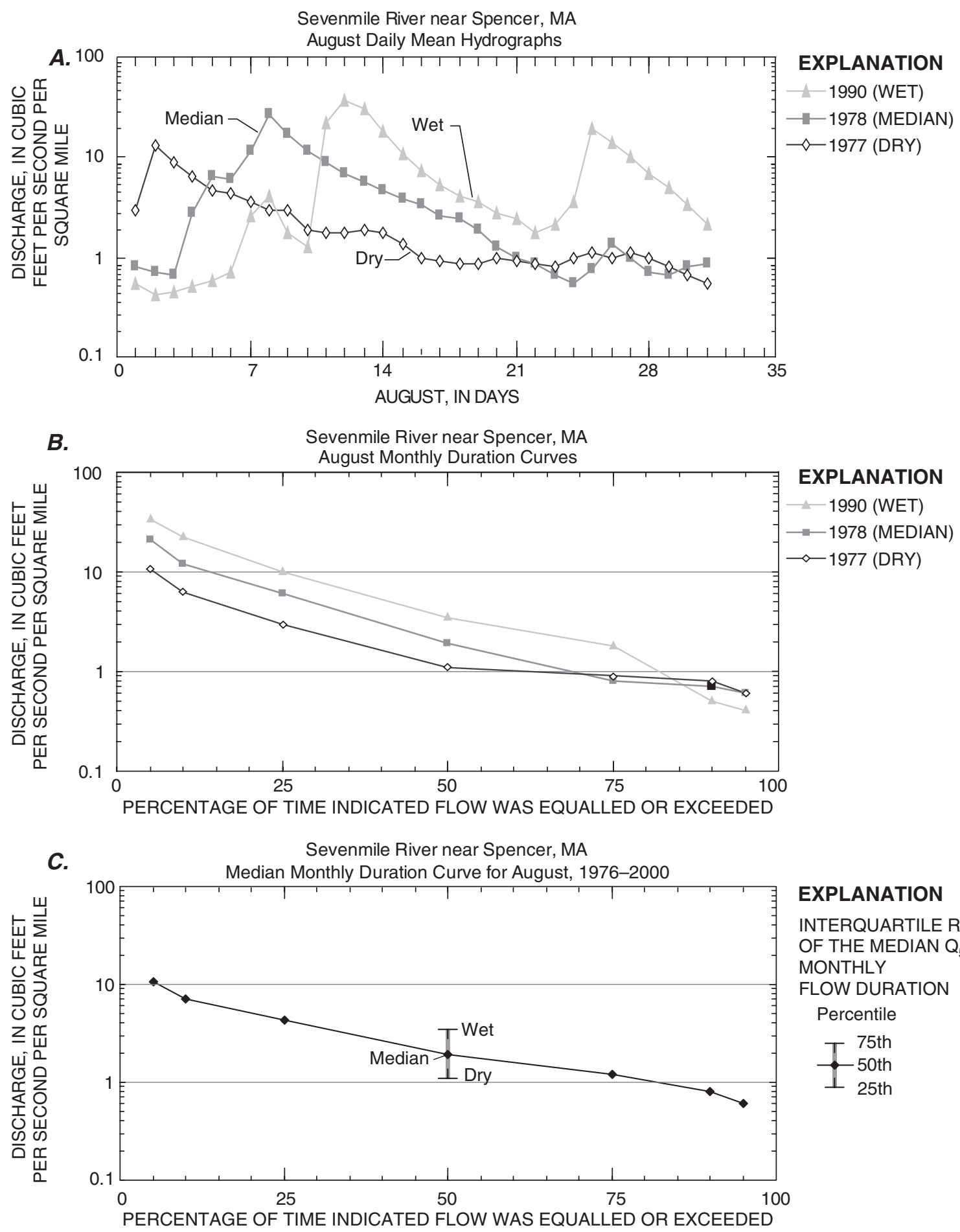

EXPLANATION

INTERQUARTILE RANGE OF THE MEDIAN $Q_{50}$ MONTHLY FLOW DURATION Percentile

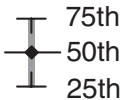

Figure 4. August streamflows at the Sevenmile River near Spencer, MA (01175670): $A$, August daily mean hydrographs for 1990, 1978, and 1977 water years; $B$, August monthly duration curves for 1990, 1978, and 1977 water years; and $C$, August median monthly duration curve, 1976-2000. 


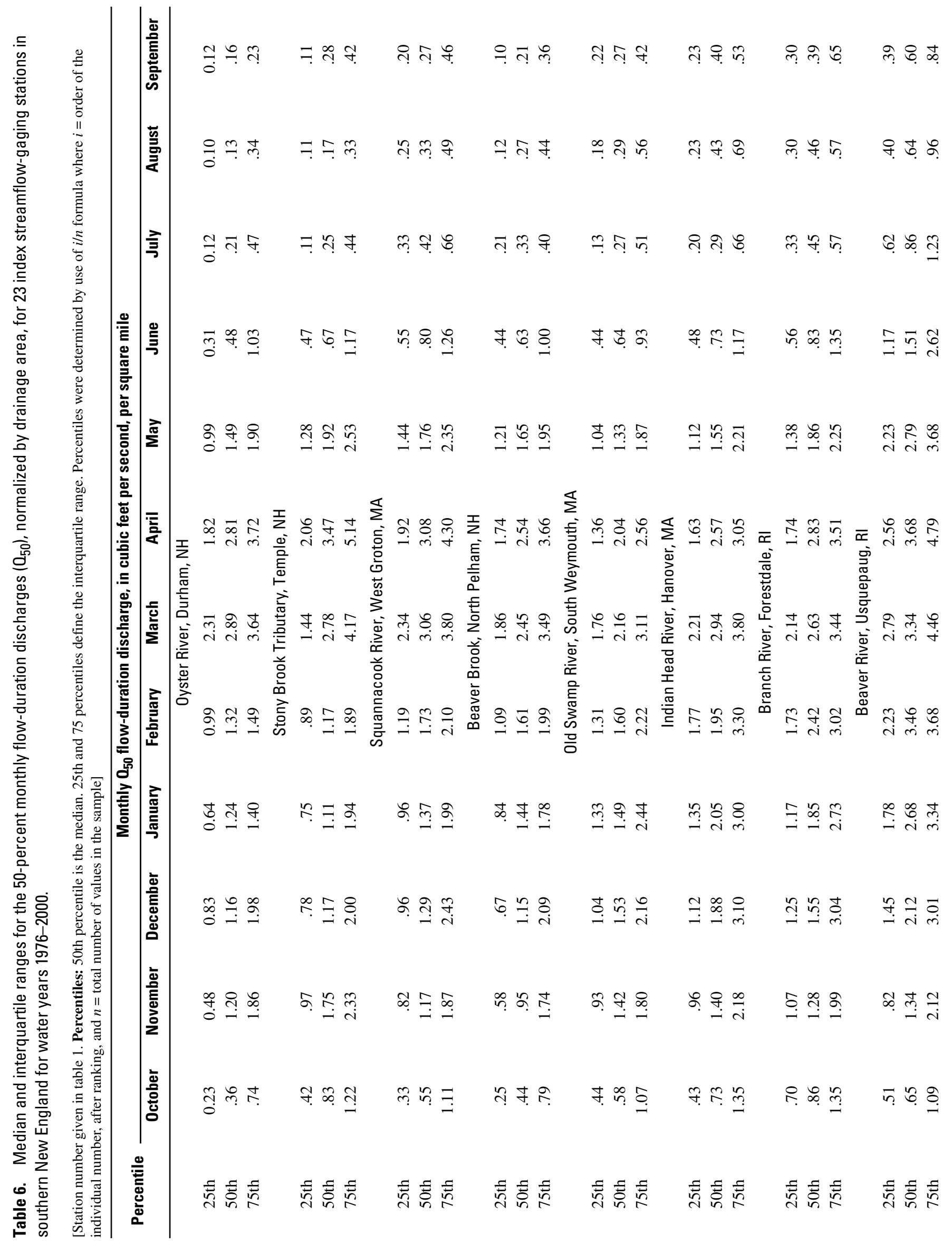




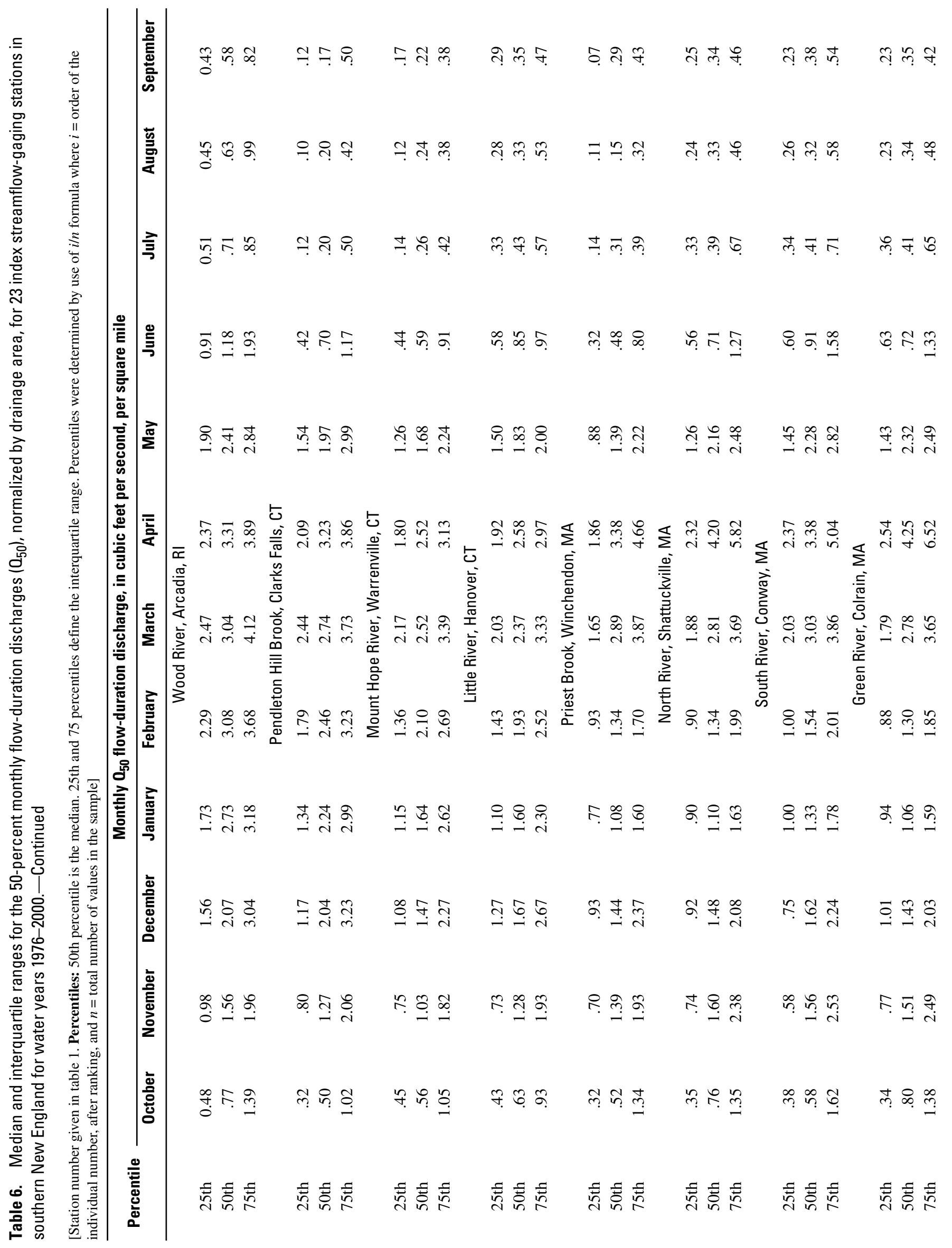




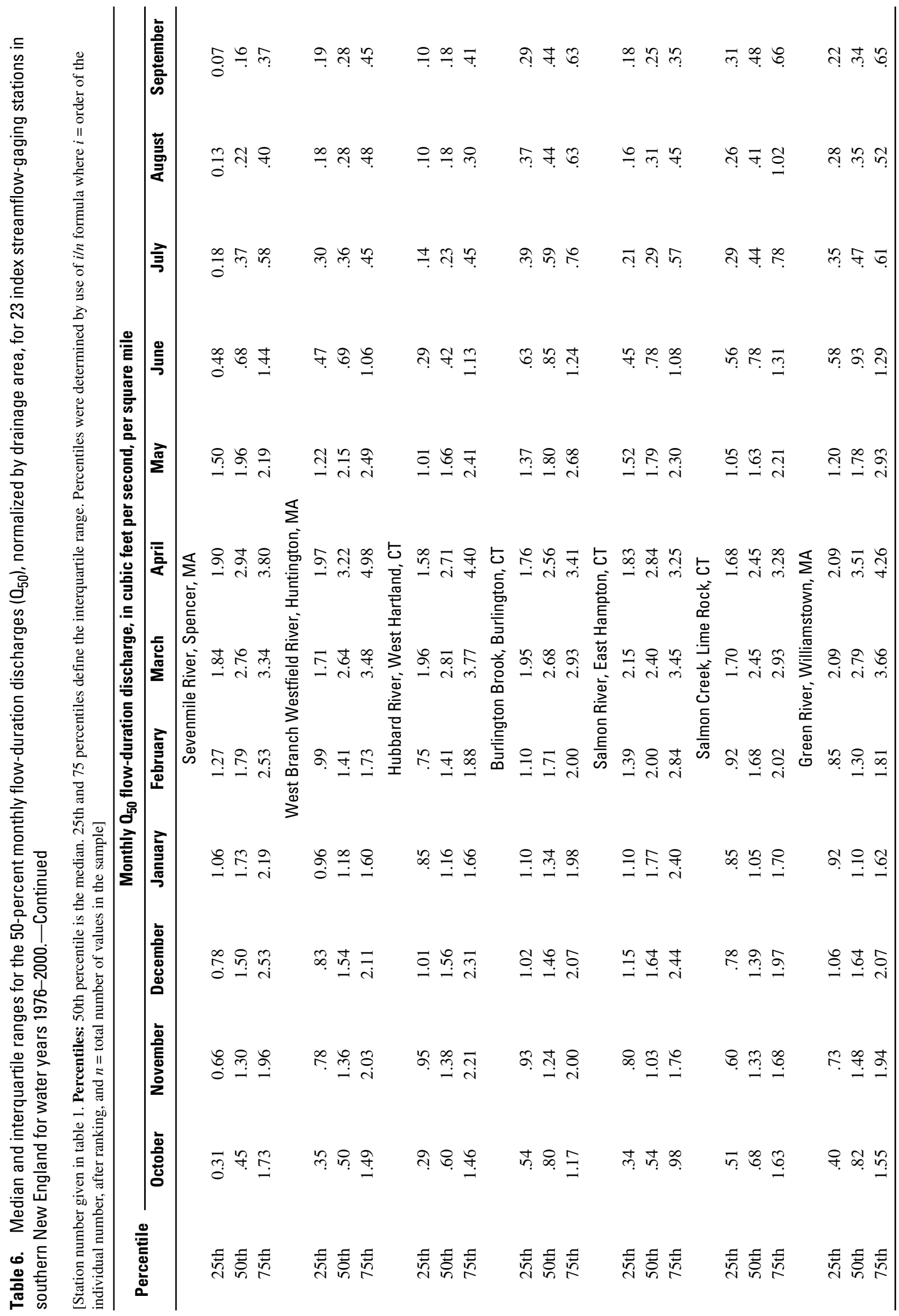


Methods other than those used in this report have been used by others to calculate different types of monthly-flow duration curves. For example, flow-duration curves created from all the mean daily flows for a given month for the period of record at a station, or created from the monthly average flows for the period of record at a station are also called monthly flow durations. These methods would not describe the variability of flows from year to year, and so were not used in this report.

\section{Low-Flow Statistics}

Low-flow statistics describe the lowest mean daily discharge that occurs over a given number of consecutive days (n-days), such as over 7-, 30-, or 90-consecutive-days. The magnitudes of n-day streamflows typically increase as the number of days increases because of the increased likelihood of a storm that will raise flows. For example, if the mean flow for each consecutive 7-day period is computed from daily records, the lowest mean value for the year is the 7-day low flow. These consecutive-day low-flow periods can occur either during or across months and may occur at any time during the year, not necessarily in summer. Low-flow data were analyzed on the basis of a climatic year from April 1 to March 31, to bracket the low-flow season. Low-flow statistics were determined for the index stations for 1-, 2-, 3-, 7-, 10-, 30-, 60-, and 90-day periods. Log-Pearson Type III low-flow exceedance probabilities and recurrence intervals were not calculated for this report. Instead, the distribution of n-day low-flow statistics over the 25-year study period was determined by use of a MICROSOFT-EXCEL spreadsheet, in which annual n-day discharges (one for each year between 1976 and 2000) were ranked in ascending order of discharge, and a percentile was calculated from the cumulative distribution frequency position of the sorted data. The median and IQR range for these n-day low-flow statistics, normalized by drainage area, are shown in table 7 for each of the 23 index stations.

\section{Characterization of Flow Regimes for Index Stations}

Annual hydrographs of median monthly flow durations were prepared for the 23 index stations, normalized by drainage area. Streamflows were normalized by drainage area because drainage area was expected to be the variable that would explain most of the variability in flow between stations (Ries and Friesz, 2000). Comparisons of the annual hydrographs showed that hydrographs for stations near each other tended to have similar shapes and magnitudes. During late fall, winter, and spring, the shape and magnitude of the hydrographs showed characteristic differences between stations in the northwest and southeast portions of southern New England. Differences in the hydrographs in the late fall, winter, and spring were most apparent during January and February, when precipitation falling as snow is stored in the snowpack, and during March and April, when the snow melts and runs off. In general, streamflows at stations to the north and west increase from October through December, and decline in January and February as a result of the accumulation and storage of precipitation within the snowpack. Melting snowpacks and concurrent precipitation cause median monthly streamflows to increase steeply in March and peak in April. Flows then decline through May and June, and level off in July, August, and September. In contrast, the hydrographs for rivers to the south and east in general have a much more rounded shape.

Streamflows in these rivers generally increase steadily from October through December. Milder winters cause median monthly flows to increase less steeply or level off in January or February. Peak flows occur earlier and last longer, extending through March and April. Flows then decline through May and June, and level off in July, August, and September. During summer and early fall, the hydrographs from all regions tended to have similar shapes. The magnitude of the median $\mathrm{Q}_{50}$ discharges for the index stations during summer, however, tended to be higher for basins with high percentages of sand and gravel in the drainage basins.

\section{Classification of Index Stations}

Index stations were combined into groups primarily by inspection of the shapes and magnitudes of the annual hydrographs of median monthly flow durations, normalized by drainage area. Groups of index gages were identified that had similar median $\mathrm{Q}_{50}$ flow durations for the high- and low-flow portions of the hydrograph. A flow of $1 \mathrm{ft}^{3} / \mathrm{s} / \mathrm{mi}^{2}$ was used to split hydrographs into a high-flow period (November-May), and a low-flow period (June-October). Index stations that had similar median $\mathrm{Q}_{50}$ flow durations for the November to May high-flow period were located in different regions in southern New England. Index stations that had similar median $Q_{50}$ flow durations for the June to October low flow period had similar base-flow indexes and percentage of sand and gravel in the contributing area.

To characterize streamflows, index stations were grouped into four regional groups, roughly paralleling the coast, for the November to May high flow period, and into two groups with similar base-flow indexes and percentage of sand and gravel contributing areas for the June to October low flow period. The selection of index stations for each group was confirmed by maximizing the coefficient of determination $\left(\mathrm{R}^{2}\right)$ from a regression analysis of monthly discharge and drainage area for each group of stations for each month. The $\mathrm{R}^{2}$ for all 23 index stations showed that drainage area explained between 82 and 97 percent of the streamflow variability for each month. Grouping the stations by geographic region for the high-flow period and by percent sand and gravel for the lowflow period generally improved the $\mathrm{R}^{2}$ by up to 10 percent. 


\section{Streamflow Requirements and Streamflow Characteristics at Index Stations in Southern New England}

Table 7. Median and interquartile ranges for $n$-day low-flow statistics for 23 index stations in southern New England for water years 1976-2000.

[Percentile: 50th percentile is the median. 25th and 75 percentiles define the interquartile range. Percentiles were determined by use of $i / n$ formula where $i=$ order of the individual number, after ranking, and $n=$ total number of values in the sample]

\begin{tabular}{|c|c|c|c|c|c|c|c|c|}
\hline \multirow{2}{*}{ Percentile } & \multicolumn{8}{|c|}{$\mathrm{N}$-day discharge, in cubic feet per second } \\
\hline & 1-day & 2-day & 3-day & 7-day & 10-day & 30-day & 60-day & 90-day \\
\hline \multicolumn{9}{|c|}{ Stony Brook Tributary near Temple, NH } \\
\hline 50 th & .21 & .21 & .22 & .24 & .24 & .43 & .66 & .97 \\
\hline 75 th & .34 & .35 & .39 & .50 & .57 & .98 & 1.53 & 1.78 \\
\hline 50 th & .23 & .23 & .24 & .28 & .31 & .48 & .87 & 1.35 \\
\hline 75 th & .37 & .38 & .39 & .48 & .49 & .85 & 1.67 & 2.15 \\
\hline \multicolumn{9}{|c|}{ Burlington Brook near Burlington, CT } \\
\hline 25 th & .62 & .65 & .64 & .69 & .72 & 1.06 & 1.33 & 1.60 \\
\hline 25 th & .22 & .24 & .26 & .31 & .33 & .59 & .98 & 1.49 \\
\hline 50th & .35 & .36 & .37 & .47 & .55 & .91 & 1.39 & 1.90 \\
\hline 75 th & .51 & .54 & .57 & .68 & .80 & 1.18 & 1.97 & 2.50 \\
\hline \multicolumn{9}{|c|}{ Sevenmile River near Spencer, MA } \\
\hline 25 th & .20 & .22 & .24 & .32 & .35 & .46 & 1.01 & 1.69 \\
\hline 50th & .31 & .32 & .34 & .41 & .44 & .98 & 1.57 & 2.14 \\
\hline 75th & .76 & .82 & .88 & 1.06 & 1.14 & 1.81 & 3.33 & 4.32 \\
\hline \multicolumn{9}{|c|}{ Beaver River near Usquepaug, RI } \\
\hline 25 th & 2.03 & 2.10 & 2.15 & 2.31 & 2.32 & 2.65 & 3.35 & 4.57 \\
\hline 50 th & 3.00 & 3.08 & 3.08 & 3.25 & 3.37 & 4.59 & 4.94 & 5.66 \\
\hline 25 th & .61 & .63 & .65 & .74 & .92 & 1.29 & 2.23 & 2.38 \\
\hline 50 th & 1.30 & 1.35 & 1.38 & 1.51 & 1.54 & 2.50 & 3.80 & 6.09 \\
\hline 75 th & 1.73 & 1.80 & 1.83 & 2.03 & 2.16 & 3.90 & 5.14 & 8.54 \\
\hline \multicolumn{9}{|c|}{ Hubbard River near West Hartland, CT } \\
\hline 25 th & .67 & .68 & .68 & .78 & .88 & 1.53 & 2.27 & 3.48 \\
\hline 50 th & 1.05 & 1.08 & 1.08 & 1.27 & 1.51 & 2.64 & 4.22 & 6.55 \\
\hline 75 th & 1.58 & 1.58 & 1.72 & 1.85 & 2.09 & 4.61 & 7.61 & 9.88 \\
\hline \multicolumn{9}{|c|}{ South River near Conway, MA } \\
\hline 25 th & 3.38 & 3.43 & 3.52 & 3.91 & 4.12 & 5.26 & 6.32 & 8.12 \\
\hline 50th & 4.25 & 4.30 & 4.40 & 4.76 & 5.19 & 6.84 & 8.20 & 10.18 \\
\hline 75th & 5.93 & 6.00 & 6.14 & 6.86 & 7.32 & 9.29 & 13.86 & 15.65 \\
\hline
\end{tabular}


Table 7. Median and interquartile ranges for $n$-day low-flow statistics for 23 index stations in southern New England for water years 1976-2000.-Continued

[Percentile: 50th percentile is the median. 25th and 75 percentiles define the interquartile range. Percentiles were determined by use of $i / n$ formula where $i=$ order of the individual number, after ranking, and $n=$ total number of values in the sample]

\begin{tabular}{|c|c|c|c|c|c|c|c|c|}
\hline \multirow{2}{*}{ Percentile } & \multicolumn{8}{|c|}{$\mathrm{N}$-day discharge, in cubic feet per second } \\
\hline & 1-day & 2-day & 3-day & 7-day & 10-day & 30-day & 60-day & 90-day \\
\hline \multicolumn{9}{|c|}{ Mount Hope River near Warrenville, CT } \\
\hline 50 th & 2.00 & 2.13 & 2.23 & 2.56 & 2.76 & 5.35 & 6.85 & 10.76 \\
\hline 75 th & 3.25 & 3.36 & 3.42 & 4.33 & 4.65 & 6.68 & 9.58 & 14.70 \\
\hline 50 th & 5.95 & 6.03 & 6.08 & 6.54 & 6.77 & 8.49 & 11.61 & 13.22 \\
\hline 75 th & 8.50 & 8.59 & 8.78 & 9.49 & 9.71 & 13.37 & 18.30 & 23.02 \\
\hline \multicolumn{9}{|c|}{ Little River near Hanover, CT } \\
\hline 25 th & 4.18 & 4.25 & 4.39 & 4.68 & 4.72 & 6.27 & 7.83 & 9.32 \\
\hline \multicolumn{9}{|c|}{ Indian Head River at Hanover, MA } \\
\hline 25 th & 2.15 & 2.36 & 2.42 & 2.93 & 3.22 & 5.10 & 7.21 & 8.87 \\
\hline 50 th & 3.35 & 3.48 & 3.83 & 4.44 & 4.88 & 6.51 & 10.38 & 13.56 \\
\hline 75 th & 5.48 & 6.18 & 6.38 & 7.18 & 7.47 & 10.10 & 14.74 & 21.72 \\
\hline \multicolumn{9}{|c|}{ Wood River near Arcadia, RI } \\
\hline 25 th & 7.33 & 7.46 & 7.68 & 8.56 & 8.92 & 10.99 & 13.73 & 16.08 \\
\hline 50 th & 9.65 & 10.23 & 10.45 & 11.52 & 11.97 & 14.74 & 18.78 & 25.59 \\
\hline 75 th & 14.75 & 14.75 & 15.08 & 16.57 & 16.90 & 21.28 & 25.28 & 30.85 \\
\hline \multicolumn{9}{|c|}{ Green River near Colrain, MA } \\
\hline 25 th & 5.25 & 5.28 & 5.33 & 5.90 & 6.33 & 9.06 & 10.48 & 11.68 \\
\hline 50th & 6.60 & 6.75 & 6.83 & 7.40 & 7.89 & 10.05 & 13.86 & 16.36 \\
\hline 75 th & 7.60 & 7.64 & 7.87 & 8.90 & 9.53 & 13.60 & 18.59 & 24.54 \\
\hline \multicolumn{9}{|c|}{ Green River at Williamstown, MA } \\
\hline 25 th & 5.13 & 5.14 & 5.22 & 5.60 & 6.08 & 8.15 & 10.13 & 12.08 \\
\hline 50 th & 7.00 & 7.15 & 7.25 & 7.77 & 8.51 & 10.93 & 12.53 & 17.13 \\
\hline 75 th & 9.43 & 9.71 & 9.89 & 11.10 & 11.92 & 14.95 & 21.26 & 27.54 \\
\hline \multicolumn{9}{|c|}{ Beaver Brook at North Pelham, MH } \\
\hline 25 th & 1.70 & 1.70 & 1.70 & 1.80 & 1.88 & 2.63 & 4.44 & 6.15 \\
\hline 50 th & 2.00 & 2.05 & 2.10 & 2.34 & 2.67 & 4.58 & 7.88 & 10.57 \\
\hline 75 th & 5.00 & 5.05 & 5.10 & 5.81 & 6.29 & 10.76 & 16.10 & 19.51 \\
\hline \multicolumn{9}{|c|}{ Squannacook River near West Groton, MA } \\
\hline 25 th & 9.48 & 9.59 & 9.70 & 10.15 & 10.43 & 12.69 & 14.50 & 17.27 \\
\hline 50 th & 12.00 & 12.75 & 13.00 & 13.57 & 14.05 & 16.43 & 20.49 & 26.13 \\
\hline 75th & 14.25 & 14.25 & 14.61 & 15.25 & 19.65 & 26.81 & 26.81 & 36.30 \\
\hline \multicolumn{9}{|c|}{ North River at Shattuckville, MA } \\
\hline 25 th & 10.00 & 10.45 & 10.63 & 11.85 & 12.40 & 19.41 & 24.42 & 29.33 \\
\hline 50th & 13.50 & 13.75 & 14.50 & 15.64 & 16.05 & 22.67 & 30.63 & 36.50 \\
\hline 75th & 16.00 & 16.00 & 16.42 & 17.96 & 19.10 & 27.79 & 43.29 & 54.90 \\
\hline
\end{tabular}




\section{Streamflow Requirements and Streamflow Characteristics at Index Stations in Southern New England}

Table 7. Median and interquartile ranges for $n$-day low-flow statistics for 23 index stations in southern New England for water years 1976-2000.-Continued

[Percentile: 50th percentile is the median. 25th and 75 percentiles define the interquartile range. Percentiles were determined by use of $i / n$ formula where $i=$ order of the individual number, after ranking, and $n=$ total number of values in the sample]

\begin{tabular}{|c|c|c|c|c|c|c|c|c|}
\hline \multirow{2}{*}{ Percentile } & \multicolumn{8}{|c|}{$\mathrm{N}$-day discharge, in cubic feet per second } \\
\hline & 1-day & 2-day & 3-day & 7-day & 10-day & 30-day & 60-day & 90-day \\
\hline \multicolumn{9}{|c|}{ Branch River at Forestdale, RI } \\
\hline 50 th & 18.50 & 19.00 & 19.50 & 20.86 & 22.20 & 25.57 & 31.97 & 46.29 \\
\hline 75 th & 23.50 & 24.88 & 25.33 & 28.39 & 30.60 & 37.63 & 47.97 & 56.73 \\
\hline 50 th & 10.50 & 10.75 & 11.00 & 12.57 & 13.90 & 20.89 & 24.27 & 34.71 \\
\hline 75 th & 15.25 & 15.75 & 15.92 & 17.07 & 17.85 & 28.68 & 41.52 & 48.86 \\
\hline \multicolumn{9}{|c|}{ Salmon River near East Hampton, CT } \\
\hline 25 th & 6.98 & 7.04 & 7.48 & 7.94 & 8.96 & 13.55 & 15.88 & 21.91 \\
\hline
\end{tabular}

Once the stations groupings were finalized, the $\mathrm{R}^{2}$ showed that drainage area explained more than 95 percent of streamflow variability when the stations were grouped geographically for the period from November through May, and more than 89 percent of streamflow variability when the stations were grouped by percent sand and gravel and base-flow index for the period from June through October. The groupings were judged to explain a significant enough portion of the variability to justify combining the $\mathrm{Q}_{50}$ discharges from the stations into a single data set for each group. These combined data sets were used to construct generalized annual hydrographs of monthly flows for each group.

\section{Flow Regimes for Index-Station Groups}

Classification of the index stations into geographic regions on the basis of the magnitude of the median $\mathrm{Q}_{50}$ for November through May resulted in four groups of index stations with hydrographs that have generally distinct shapes and magnitudes: a northwest region, a north-central region, a southcentral region, and a south-coastal region (fig. 5). These hydrologic regions roughly correspond to areas that have similar mean seasonal snowfalls (New Hampshire Department of Safety, 2003), and also similar average winter temperatures (Zielinski and Keim, 2003), evapotranspiration (Randall, 1996), and water available for infiltration (Lyford and Cohen, 1988). In general, the shapes and magnitudes of the hydrographs change along a continuum from southeast to northwest. A few stations near the boundaries of these regions could have been classified into adjacent geographic groups with only a minor effect on the combined flow statistics. The lack of long-term index stations along the Interstate 495 corridor in eastern and northeastern Massachusetts makes it difficult to extend results into these regions. Streamflow characteristics in these areas may differ from those of adjacent regions.

Classification of the index stations into groups on the basis of magnitude of median $\mathrm{Q}_{50}$ for June through October resulted in two groups of index stations with hydrographs that have similar shapes but different magnitudes (fig. 6). Index stations that had high median $\mathrm{Q}_{50}$ discharges tended to have a high baseflow index (7-day minimum flow divided by mean annual daily flow (Richter and others, 1996) and high percentages of sand and gravel, and streams that had low median $\mathrm{Q}_{50}$ discharges tended to have a low base-flow index and low percentages of sand and gravel. The group with high median $\mathrm{Q}_{50}$ discharges (the high median monthly flow, or HF group), consisted of six stations that had a base-flow indexes of greater than 0.12 and contributing areas with more than 20 percent sand and gravel. The group with low median $\mathrm{Q}_{50}$ discharges (the low median monthly flow, or LF group), consisted of 17 stations that had a base-flow index of less than 0.12 , and contributing areas with less than 20 percent sand and gravel. One station included in the HF group, Salmon Creek at Lime Rock, CT (01199050), is associated with a low percentage of sand and gravel (15 percent) (table 1) but high median monthly flows, possibly because the river flows through an area of carbonate-rich bedrock which can cause higher base flow (Bent, 1998). Three stations in the LF group were associated with low median monthly flows but had contributing areas with more than 20 percent sand and gravel. Stations on two of these rivers, Oyster River near Durham, NH (01073000), and Old Swamp River near South Weymouth (01105600), were associated with contributing areas of 34 and 29 percent sand and gravel, respectively. 


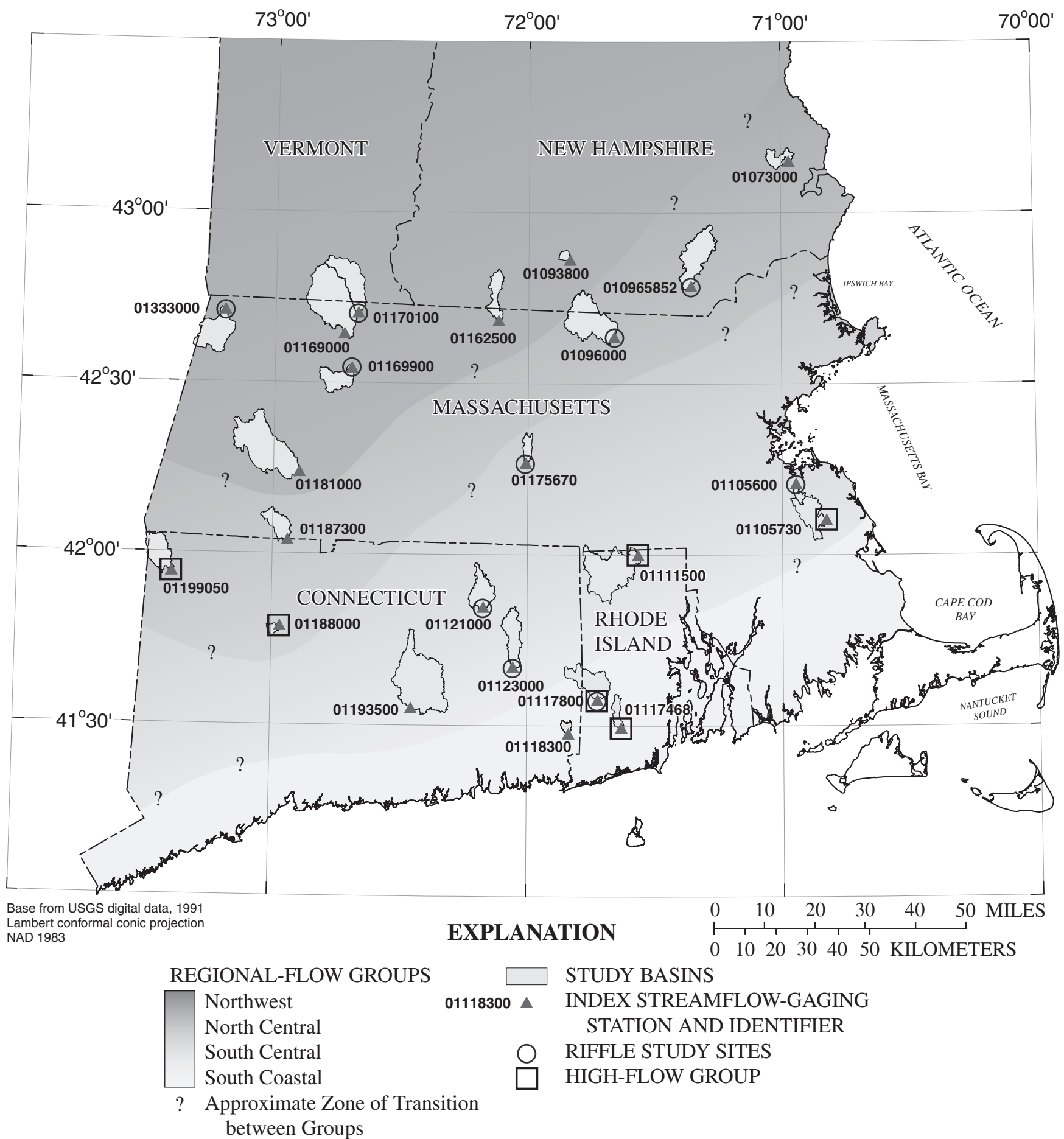

Figure 5. Classification of index streamflow-gaging stations in southern New England. 


\section{Streamflow Requirements and Streamflow Characteristics at Index Stations in Southern New England}

These rivers may have lower median monthly flows in summer when normalized by drainage area, possibly because their contributing areas include large areas of wetland, which could potentially cause reduced flows because of evapotranspiration. Water withdrawals downstream of the Old Swamp River streamflow-gaging station also could potentially affect flow at this station. The station at Squannacook River near West Groton, MA (01096000), which is in the LF group, may have lower median monthly streamflows because of shallow aquifers, in combination with the cumulative effect of groundwater withdrawals and impoundments (de Lima, 1991).

\section{Streamflow Variability for Groups of Index Stations}

To show the variability in streamflow between groups of index stations, a single data set was created for each group of index stations by combining the streamflows at the 50-percent flow duration for each month of a common 25-year period (1976-2000), normalized by drainage area, for all stations within the group. The normalized streamflow data from each station in a group could be combined because most of the variability in streamflow between stations could be explained by drainage area. Normalized median flows for each month were then calculated from the combined data sets for each group. Generalized hydrographs were prepared for the four geographic groups (northwest, north central, south central, and south coastal) for the period from November through May, and for two groups on the basis of the magnitude of median $Q_{50}$ discharges (the HF and LF groups) for the period from June through October (fig. 6). The median $\mathrm{Q}_{50}$ discharges for July, August, and September were 0.36, 0.28, and $0.27 \mathrm{ft}^{3} / \mathrm{s} / \mathrm{mi}^{2}$, respectively, for the index stations in the LF group, and 0.57, 0.49 , and $0.46 \mathrm{ft}^{3} / \mathrm{s} / \mathrm{mi}^{2}$, respectively, for the index stations in the $\mathrm{HF}$ group. These median $\mathrm{Q}_{50}$ discharges correspond to average annual exceedance probabilities of about 80, 84, and 85 percent exceedances, for both the HF and LF groups.

Streamflows in southern New England can be highly variable between years. Determination of monthly flow durations allows a description of the variability of streamflow (Vogel and Fennessey, 1994). The range between the 5th and 95th percentile of median $\mathrm{Q}_{50}$ discharges represents the 90-percent confidence interval associated with the median $\mathrm{Q}_{50}$ for each month, and can be used to indicate the high degree of variability in streamflow that can occur for an individual monthly flow duration in different years. For the 25year period from 1976 to 2000, the 90-percent confidence interval for August ranged between 0.16 and $1.24 \mathrm{ft}^{3} / \mathrm{s} / \mathrm{mi}^{2}$ for rivers in the HF group, and between 0.07 to $1.00 \mathrm{ft}^{3} / \mathrm{s} / \mathrm{mi}^{2}$ for rivers in the LF group. This indicates that the median $\mathrm{Q}_{50}$ discharges for August can change up to about $1 \mathrm{ft}^{3} / \mathrm{s} / \mathrm{mi}^{2}$ between wet and dry periods for both the HF and LF groups.
A.

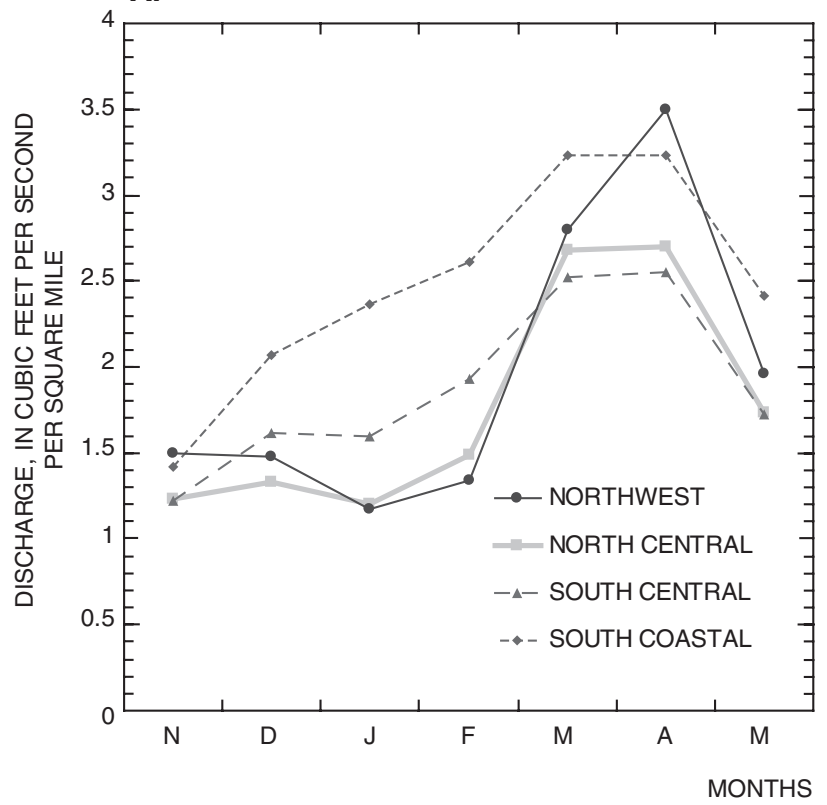

B.

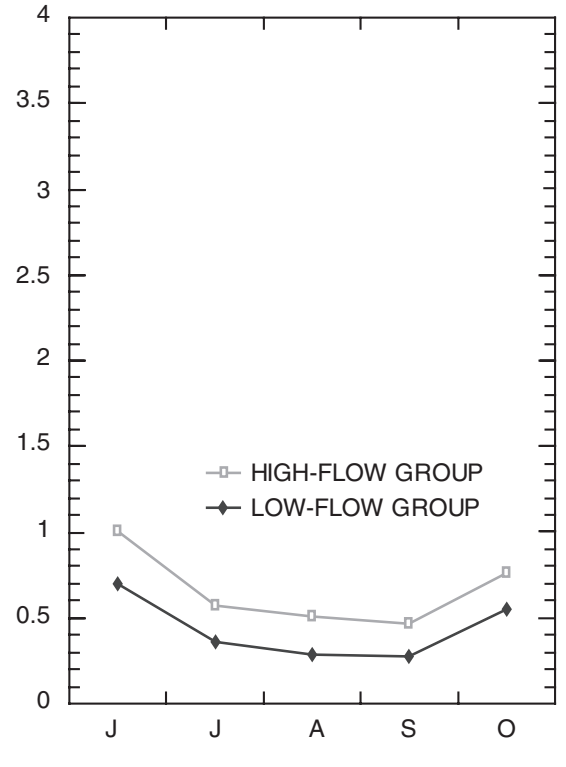

Figure 6. Regionalized medians of the 50-percent monthly flow durations, normalized by drainage area, for index stations in southern New England grouped by $A$, geographic region, November-May; and $B$, magnitude of median 50-percent monthly flow durations, June-October. 
The IQR for a monthly flow duration is a measure of the variability of that flow duration about the median and represents the 50-percent confidence interval about the median. For example, for the 25-year period from 1976 to 2000, the median $\mathrm{Q}_{50}$ for August for rivers in the HF group, normalized by drainage area, was $0.49 \mathrm{ft}^{3} / \mathrm{s} / \mathrm{mi}^{2}$, and the IQR of the $\mathrm{Q}_{50}$ ranged between 0.30 and $0.87 \mathrm{ft}^{3} / \mathrm{s} / \mathrm{mi}^{2}$. For rivers in the LF group, the median $\mathrm{Q}_{50}$ for August was $0.28 \mathrm{ft}^{3} / \mathrm{s} / \mathrm{mi}^{2}$, and the IQR of the $\mathrm{Q}_{50}$ ranged between 0.16 to $0.47 \mathrm{ft}^{3} / \mathrm{s} / \mathrm{mi}^{2}$. The IQRs about the $\mathrm{Q}_{25}, \mathrm{Q}_{50}$, and $\mathrm{Q}_{75}$ for the HF and LF groups for June through October are shown in figure $7 A-E$.

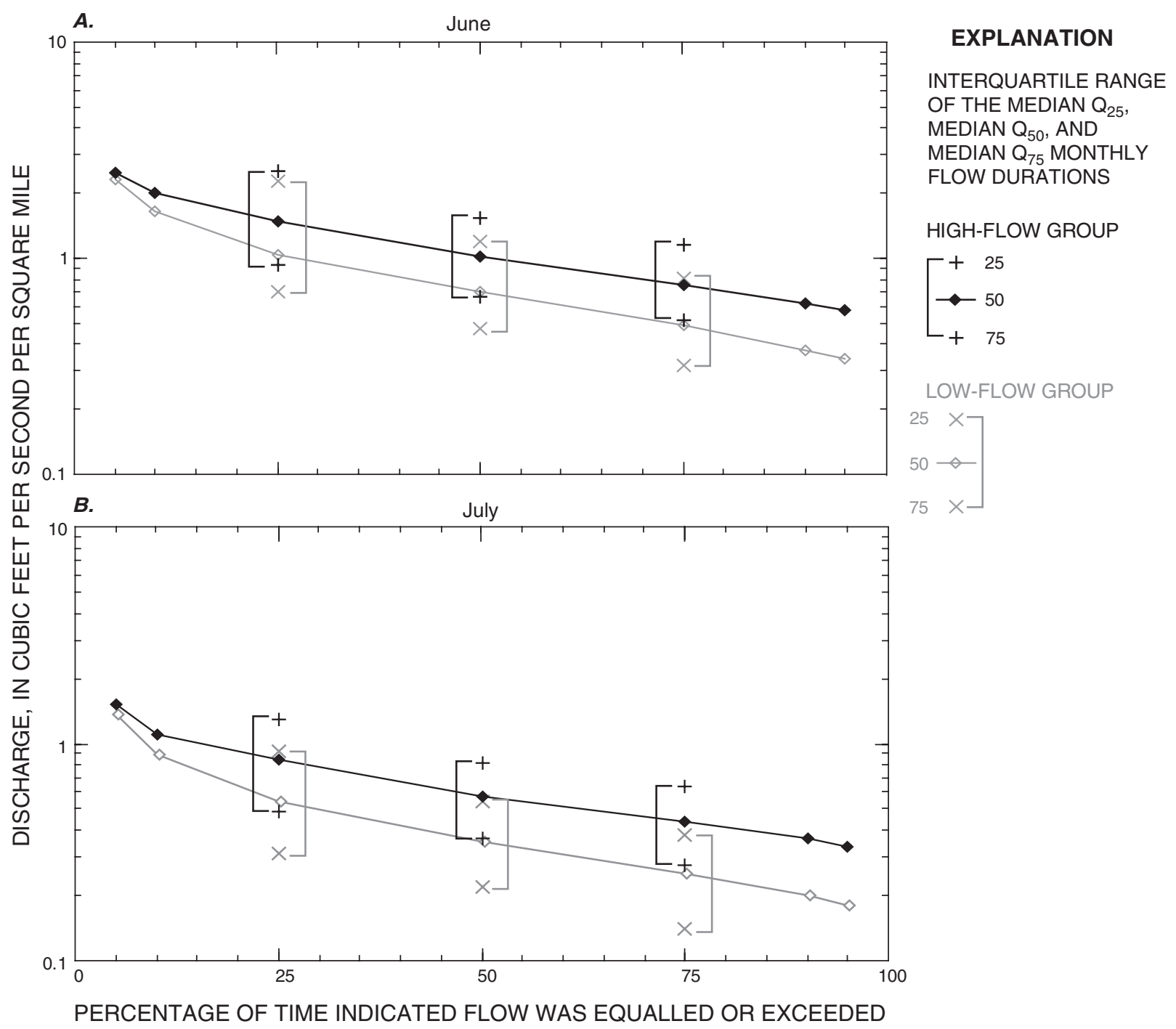

Figure 7. Median monthly flow durations, normalized by drainage area, and the interquartile range about the 25-, 50-, and 75-percent monthly flow durations for June through October for the high- and low-median monthly flow-duration groups for index stations in southern New England: $A$, June; $B$, July; $C$, August; $D$, September; and $E$, october. 


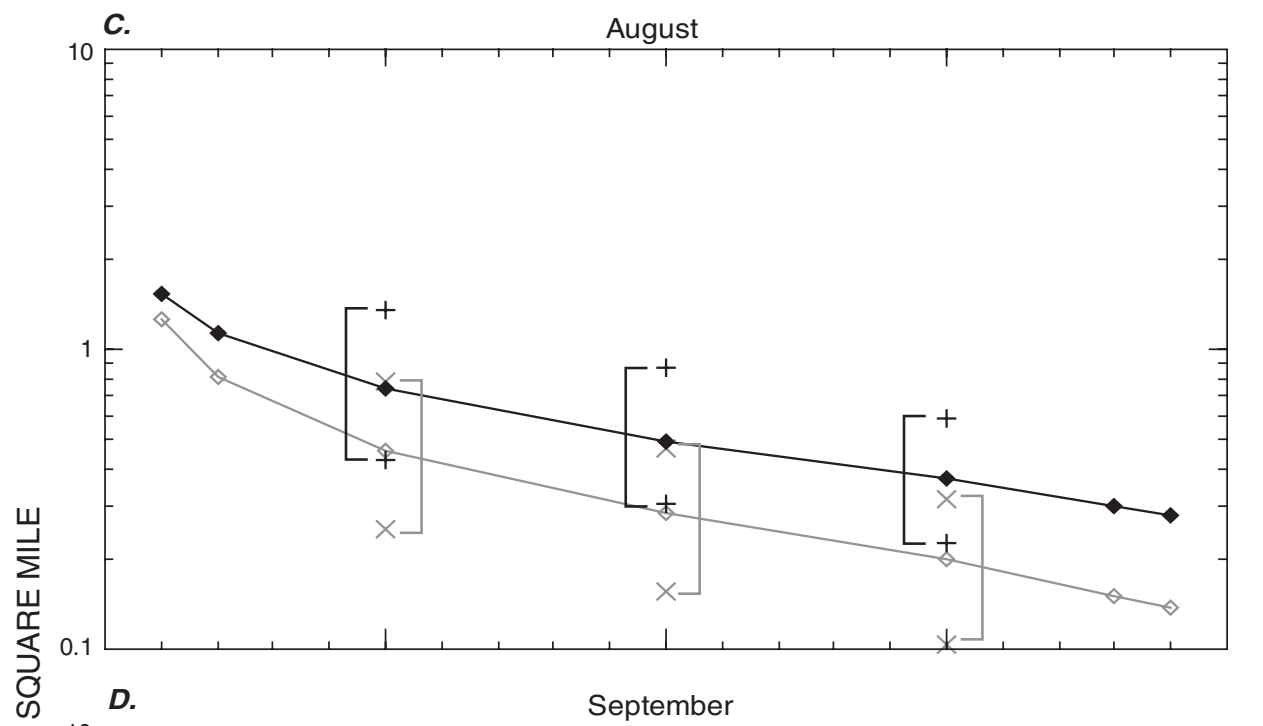

\section{EXPLANATION}

INTERQUARTILE RANGE

OF THE MEDIAN $Q_{25}$,

MEDIAN $Q_{50}$, AND

MEDIAN Q $Q_{75}$ MONTHLY

FLOW DURATIONS

HIGH-FLOW GROUP

$$
\left[\begin{array}{l}
+25 \\
\bullet-50 \\
+\quad 75
\end{array}\right.
$$

LOW-FLOW GROUP
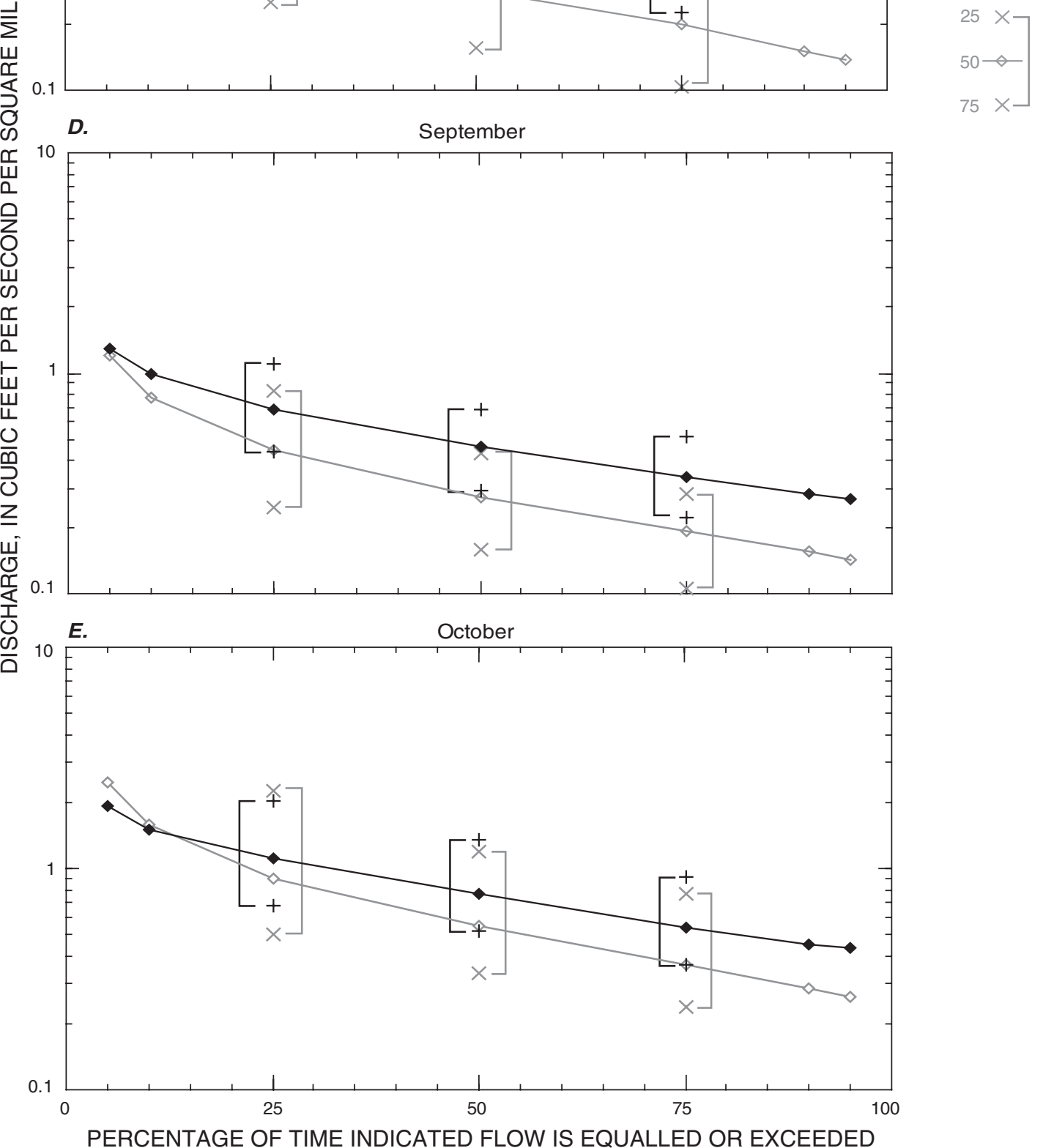

Figure 7. Median monthly flow durations, normalized by drainage area, and the interquartile range about the 25-, 50-, and 75-percent monthly flow durations for June through October for the high- and low-median monthly flow-duration groups for index stations in southern New England: $A$, June; $B$, July; $C$, August; $D$, September; and $E$, October.-Continued 


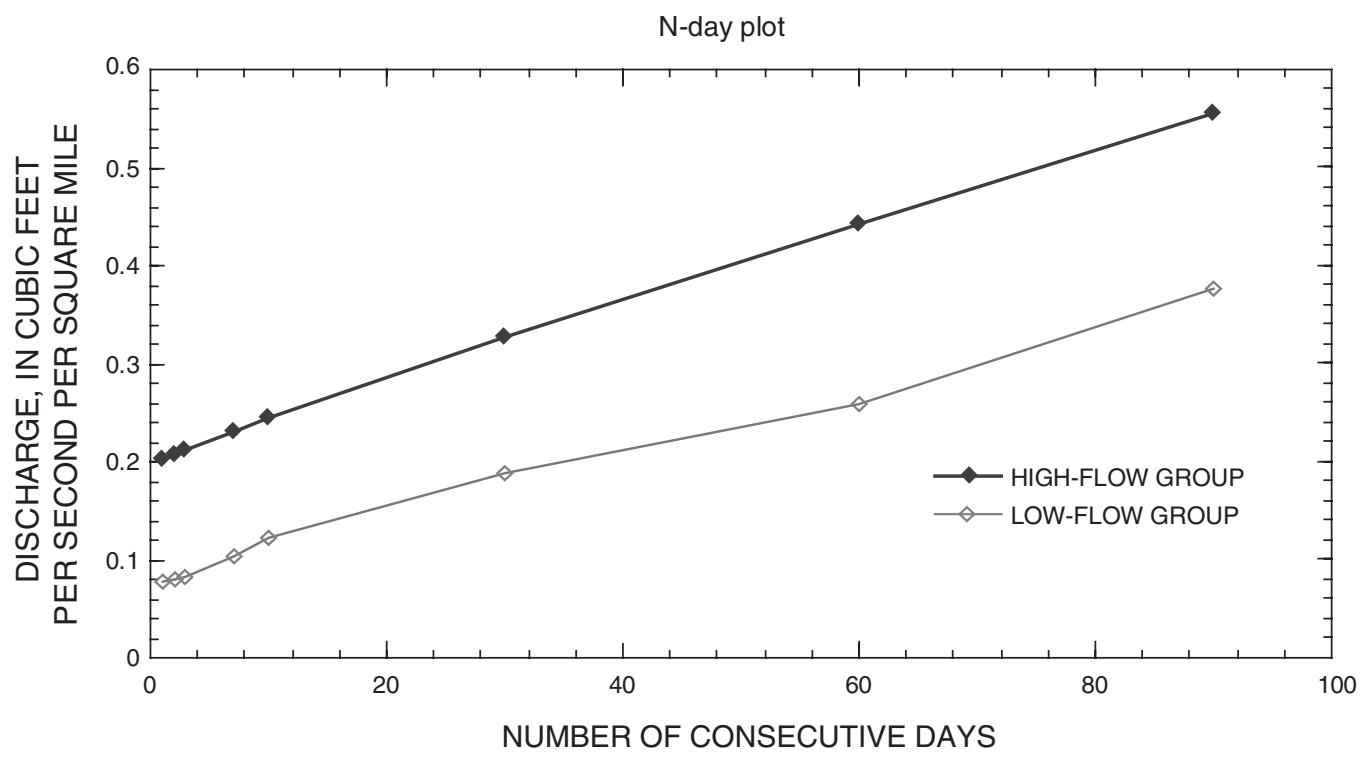

Figure 8. Median of average daily discharge for $n$-day low-flow statistics, normalized by drainage area, for the high- and low-median monthly flow-duration groups, for index stations in southern New England, for water years 1976-2000.

Streamflows in southern New England can be highly variable within a month for any given year. The difference in magnitude between the median $\mathrm{Q}_{25}$ and median $\mathrm{Q}_{75}$ illustrates the range of variability that can occur (fig 7). In addition, high flows in August $\left(\mathrm{Q}_{25}\right)$ have a greater variability than low flows $\left(Q_{75}\right)$ because the intensity of storms in a month can be variable. Therefore, the IQR about the $\mathrm{Q}_{25}$ is wider than the IQR about the $\mathrm{Q}_{75}$. For example, for rivers in the HF group, the median $\mathrm{Q}_{25}$ discharge in August was $0.74 \mathrm{ft}^{3} / \mathrm{s} / \mathrm{mi}^{2}$, and the IQR about the $\mathrm{Q}_{25}$ ranged between 0.43 and $1.36 \mathrm{ft}^{3} / \mathrm{s} / \mathrm{mi}^{2}$; in contrast, the median $\mathrm{Q}_{75}$ discharge was $0.37 \mathrm{ft}^{3} / \mathrm{s} / \mathrm{mi}^{2}$, and the IQR about the $\mathrm{Q}_{75}$ ranged between 0.23 and $0.59 \mathrm{ft}^{3} / \mathrm{s} / \mathrm{mi}^{2}$ (fig. 7C). Because low flows in August are primarily stable base flows, the IQR for the $\mathrm{Q}_{75}$ tends to be a narrow range of flows. Streamflows near the lower quartile of flows at the $\mathrm{Q}_{25}$ flow duration $\left(0.43 \mathrm{ft}^{3} / \mathrm{s} / \mathrm{mi}^{2}\right)$ are similar in magnitude to the median $\mathrm{Q}_{50}$ discharge $\left(0.49 \mathrm{ft}^{3} / \mathrm{s} / \mathrm{mi}^{2}\right)$, but are less than the upper quartile for the $\mathrm{Q}_{75}$ discharge $\left(0.59 \mathrm{ft}^{3} / \mathrm{s} / \mathrm{mi}^{2}\right)$. This shows that the higher flows in August during a dry period are about the same magnitude as the lower flows in August during a wet period, and that during dry years, 75 percent of the daily flows can be within a narrow range of discharge.

The variability of streamflows between the HF and LF groups can also be determined by use of n-day low-flowfrequency statistics. Normalized by drainage area, the median streamflows for the 7-, 30-, and 90- day periods were $0.24,0.33$, and $0.57 \mathrm{ft}^{3} / \mathrm{s} / \mathrm{mi}^{2}$, respectively, for the HF group, and 0.13 , 0.20 , and $0.37 \mathrm{ft}^{3} / \mathrm{s} / \mathrm{mi}^{2}$, respectively, for the LF groups (fig. 8). The differences between the two groups were not constant, but diverged slightly for the longer periods, differing by about
$0.1 \mathrm{ft}^{3} / \mathrm{s} / \mathrm{mi}^{2}$ at the 7-day low flow and $0.2 \mathrm{ft}^{3} / \mathrm{s} / \mathrm{mi}^{2}$ at the 90 day low flow. The 30-day low flow is less than the median $\mathrm{Q}_{50}$ for all months for the respective HF and LF groups. The 90-day low flow is approximately equal to the June median $\mathrm{Q}_{50}$ discharge for both the respective HF and LF groups.

\section{Streamflow Requirements for Habitat Protection at Index Stations in Southern New England}

Streamflow requirements for habitat protection were determined for the index stations by use of hydrologic-record and hydraulic-rating techniques. The hydrologic-record techniques used were the RVA (Richter and others, 1997), the Tennant method (Tennant, 1976), and the ABF methods (U.S. Fish and Wildlife Service, 1981; Lang, 1999). The hydraulicrating techniques used were the Wetted-Perimeter method (Nelson, 1984; Leath and Nelson, 1986; Lohr, 1993), and the R2Cross method (Nehring, 1979; Espegren, 1996, 1998).

The Instream Flow Council (2002) classified instream flow assessment techniques into three types: Standard Setting, Diagnostic, and Incremental techniques. The Tennant, ABF, Wetted-Perimeter, and R2Cross methods are called Standard Setting instream flow-assessment techniques (Instream Flow Council, 2002) because they set limits or rules to define a flow regime. The RVA method has been called a diagnostic instream flow-assessment technique (Instream Flow Council, 2002) 
because it is used to assess conditions and how they change over time. Incremental methods, the third instream flow-assessment technique, analyze single or multiple variables to enable assessment of different flow-management alternatives, and were not used in this study.

\section{Methods for Determining Streamflow Requirements Based on Hydrologic Records}

Streamflow data from 23 index stations in southern New England were used in the RVA, Tennant, and ABF methods in this report. The RVA, Tennant, and ABF methods use statistical measures of discharge time-series values to determine streamflow requirements, and require long-term flow records from a streamflow-gaging station. In general, these methods should be applied to gaged sites only if unregulated daily mean flow data are available, and can be applied to ungaged sites only by regionalizing flow statistics from streamflow-gaging stations or by simulating natural flows (that is, simulating streamflows without water withdrawals).

\section{Range of Variability Approach}

Current (2003) strategies for managing, maintaining, or restoring riverine fishery and aquatic wildlife resources and processes (Poff and others, 1998; Instream Flow Council, 2002; Postel and Richter, 2003) suggest that the native biodiversity and integrity of river ecosystems can be sustained by maintenance of the natural pattern of flow variability that led to that diversity. The Indicators of Hydrologic Alteration (IHA) method (Richter and others, 1996; Smythe, 2001) was developed by The Nature Conservancy to assess the range of variation of discharge for a river. The IHA method characterizes the range of variation of discharge at a site by use of a suite of 33 hydrologic indices. A recent study (Olden and Poff, 2003) demonstrated that the 33 hydrologic indices used by the IHA method adequately represent most of the streamflow variation at a given site. Richter and others $(1996 ; 1997)$ developed the RVA, an adaptive-management approach, to define flow-target ranges for river-ecosystem management for each of 33 IHA flow indices. The RVA flow ranges were defined as either 1 standard deviation from the mean flow or the range between the 25 th and 75th percentiles (the IQR) of the mean flow. Because hydrologic data often depart from a normal distribution, the IQR was selected as the measure of flow variability for this study. The RVA flow-management targets define a range of flows similar to those that would have occurred naturally; however, further investigation may be needed to demonstrate whether a flow range defined by the IQR would be the best range biologically for specific species or life stages of fish.

The 33 RVA statistics are divided into five general groups (table 8 ). About half of the statistics used by the RVA measure the central tendency of the magnitude or rate of change of flow, and half focus on the magnitude, duration, timing, and
Table 8. Range of Variability Approach: flow statistics for characterization of hydrologic variation.

[Source: Richter and others, 1996]

\begin{tabular}{|c|c|}
\hline Hydrologic attribute & Statistical parameter \\
\hline $\begin{array}{l}\text { The magnitude of monthly } \\
\text { discharge }\end{array}$ & $\begin{array}{l}\text { Mean monthly discharge for each } \\
\text { month. }\end{array}$ \\
\hline $\begin{array}{l}\text { The magnitude and duration } \\
\text { of annual extreme } \\
\text { discharge }\end{array}$ & $\begin{array}{l}\text { Annual minimum and maximum for } \\
\text { 1-, 3-, 7-, 30-, and 90-day periods; } \\
\text { number of zero-flow days; } 7 \text {-day } \\
\text { minimum flow divided by mean } \\
\text { flow for year. }\end{array}$ \\
\hline $\begin{array}{l}\text { The timing of annual extreme } \\
\text { discharge }\end{array}$ & $\begin{array}{l}\text { Julian date of the annual minimum } \\
\text { and maximum daily flow. }\end{array}$ \\
\hline $\begin{array}{l}\text { The frequency and duration } \\
\text { of high and low flow }\end{array}$ & $\begin{array}{l}\text { Number of low-flow and high-flow } \\
\text { pulses per year; mean duration of } \\
\text { low-flow and high-flow pulses. }\end{array}$ \\
\hline $\begin{array}{l}\text { The rate and frequency of } \\
\text { hydrographic change }\end{array}$ & $\begin{array}{l}\text { Means of all positive and negative } \\
\text { flow differences between } \\
\text { consecutive daily means; number } \\
\text { of flow rises and falls. }\end{array}$ \\
\hline
\end{tabular}

frequency of extreme events. Flow statistics such as monthly means are measures of the magnitude of flow and are general measures of the availability of habitat attributes such as wetted area, depth, or habitat volume. Flow statistics for the average discharges over a given number of consecutive days (n-day flow statistics) describe the magnitude and duration of both low and high flows, and provide measures of environmental stress and disturbance. The timing of lowest and highest flows throughout the year, and the number of days of zero flow provide a measure of seasonal disturbance or stress. The frequency and duration of time over which a specific flow persists may determine whether a particular life-cycle phase can be completed or the degree to which stressful effects such as dessication may occur. The rate and frequency of change in flow may be related to the stranding of certain organisms along the water's edge or in pools (Richter and others, 1996).

The RVA method recommends that flows be maintained within the flow-management targets at the same frequency that would have occurred naturally. For flow-management targets based on the IQR, flows would be within the IQR 50 percent of the time, higher than the flow-management target ranges 25 percent of the time, and lower than the flowmanagement target ranges 25 percent of the time. In the summer months, the streamflow at the lower limit of the target range (25th percentile) for some of these flow indices may be lower than the streamflow requirement for habitat protection determined by standard-setting methods. The RVA does not recommend maintaining flows exclusively at or near the level of the lower percentile, however. 


\section{Tennant Method}

The Tennant method bases its streamflow requirements on the observation that aquatic-habitat conditions are similar in streams carrying the same proportion of the mean annual flow $\left(Q_{M A}\right)$. The method establishes streamflow requirements on the basis of a predetermined percentage of the mean annual flow (Tennant, 1976), and associates aquatic-habitat conditions with different percentages of mean annual flow (table 9). The Tennant method is less sensitive to summer water withdrawals than methods that use low-flow statistics to determine streamflow requirements because the Tennant streamflow requirements are derived from the mean annual-flow statistic, which is largely determined by high flows.

Minimum streamflows for small streams during summer are established by the Tennant method as 40-, 30-, and 10percent of the $\mathrm{Q}_{\mathrm{MA}}$ (Annear and Conder, 1984), which represent good, fair, and poor habitat conditions, respectively, according to Tennant. At 30 percent of the $\mathrm{Q}_{\mathrm{MA}}$, most of the stream substrate is submerged; but at 10 percent of the $\mathrm{Q}_{\mathrm{MA}}$, half or more of the stream substrate can be exposed (Tennant, 1976). The 30-percent $Q_{M A}$ value is often used to determine minimum streamflow requirements in summer. A modification of the Tennant method, used in the Canadian Atlantic Provinces, designates 25 percent of the $\mathrm{Q}_{\mathrm{MA}}$ as the minimum streamflow requirement in summer (Dunbar and others, 1998).

To account for seasonal streamflow variability, the Tennant method established different streamflow requirements for the summer and winter seasons (Tennant, 1976). In the mountainous western United States, where the Tennant method was developed, precipitation patterns and snowmelt runoff typically result in low streamflows in fall and early winter and high streamflows in the spring and summer. Therefore, the Tennant streamflow recommendations are higher in the summer than in the winter. In southern New England, streamflow generally is lowest in mid-summer and early fall, and highest in

Table 9. Relations between aquatic-habitat condition and mean annual flow described by the Tennant method for small streams.

[Source: Tennant, 1976. $\mathrm{Q}_{\mathrm{MA}}$, mean annual flow; <, actual value is less than value shown]

\begin{tabular}{lrc}
\hline $\begin{array}{c}\text { Aquatic-habitat } \\
\text { condition for } \\
\text { small streams }\end{array}$ & $\begin{array}{c}\text { Percentage of } \mathbf{Q}_{\mathbf{M A}} \\
\text { April-September }\end{array}$ & $\begin{array}{c}\text { Percentage of } \mathbf{Q}_{\mathbf{M A}} \\
\text { October-March }\end{array}$ \\
\hline Flushing flows & 200 & 200 \\
Optimum range & $60-100$ & $60-100$ \\
Outstanding & 60 & 40 \\
Excellent & 50 & 30 \\
Good & 40 & 20 \\
Fair & 30 & 10 \\
Poor & 10 & 10 \\
Severe degradation & $<10$ & $<10$ \\
\hline
\end{tabular}

spring. Thus the summer streamflow criteria recommended by Tennant may be high. Because low summer streamflows in southern New England may also be linked to additional stresses, such as high stream temperatures and low dissolved oxygen concentrations, both the Tennant summer and winter criteria are evaluated in this report for use in Massachusetts during summer.

\section{New England Aquatic-Base-Flow Method}

The New England Aquatic-Base-Flow (ABF) method calculates streamflow requirements for gaged, unregulated, free-flowing rivers, and uses default streamflow requirements for regulated rivers, rivers that have a drainage area of less than $50 \mathrm{mi}^{2}$, rivers without streamflow records, or rivers whose streamflow-gaging stations have poor-quality streamflow records or have a period of record of less than 25 years. The ABF-method default streamflow requirements are $0.5 \mathrm{ft}^{3} / \mathrm{s} / \mathrm{mi}^{2}$ for summer, $1.0 \mathrm{ft}^{3} / \mathrm{s} / \mathrm{mi}^{2}$ for fall and winter, and $4.0 \mathrm{ft}^{3} / \mathrm{s} / \mathrm{mi}^{2}$ for spring (table 10). These seasonal flow requirements were determined from averaging the medians of selected monthly mean flows, in $\mathrm{ft}^{3} / \mathrm{s} / \mathrm{mi}^{2}$, from 48 streamflow-gaging stations throughout New England (U.S. Fish and Wildlife Service, 1981). The ABF default flow for summer was determined by averaging the medians of the monthly mean flows for August for the 48 stations. August is assumed to represent the month of greatest stress for aquatic organisms because of the combination of low flows, high temperatures, diminished living space, low dissolved oxygen, and reduced availability of food. The median value reflects the ability of aquatic communities to withstand periods of lower flow if provided with the opportunity to recover during periods of higher flow (R. Abele, U.S. Environmental Protection Agency, written commun., 2003). The ABF default flow for the fall and winter seasons was determined by averaging the medians of the monthly mean flows from the 48 stations for February; and the ABF default flow for spring was determined from an average of the April and May average values for the medians of the monthly mean flows for the 48 rivers. The analysis included unregulated rivers in each state in New England. The

Table 10. Seasonal New England Aquatic-Base-Flow default streamflow requirements.

[Source: U.S. Fish and Wildlife Service, 1981. $\mathrm{ft}^{3} / \mathrm{s} / \mathrm{mi}^{2}$, cubic foot per second per square mile]

\begin{tabular}{ccc}
\hline \multicolumn{1}{c}{$\begin{array}{c}\text { Season } \\
\text { (months) }\end{array}$} & Period & $\begin{array}{c}\text { Instantaneous } \\
\text { streamflow } \\
\left(\mathbf{f t}^{3} / \mathbf{s} / \mathbf{m i}^{2}\right)\end{array}$ \\
\hline $\begin{array}{c}\text { Summer (mid-June to } \\
\text { mid-October) }\end{array}$ & low flow \\
$\begin{array}{c}\text { Fall/Winter (mid-October } \\
\text { to March) }\end{array}$ & $\begin{array}{c}\text { spawning and } \\
\text { incubation }\end{array}$ \\
Spring (April to mid-June) & $\begin{array}{c}\text { spawning and } \\
\text { incubation }\end{array}$ & 4.0 \\
\hline
\end{tabular}


drainage areas of these 48 stations ranged from 53.8 to $5,690 \mathrm{mi}^{2}$, with a median of $135.5 \mathrm{mi}^{2}$. The periods of record at the stations ranged from 31 to 81 years.

The U.S. Fish and Wildlife Service's (USFWS) August median-flow statistic was developed to be used as a standard-setting method, and as such, was designed to identify a conservative level of protection for aquatic resources (Lang, 1999). The USFWS calculates the ABF August medianflow statistic as the median of the monthly mean flows for August over the period of record (U.S. Fish and Wildlife Service, 1981; Lang, 1999). To make this calculation, a monthly mean-flow statistic is first determined for each year by averaging the 31 daily mean flows in August. These monthly mean values (one for each month and year for the period of record) are then combined and ranked, and the median value is identified. Generally, medians calculated from monthly mean streamflows are higher than those calculated from daily mean streamflows because a small number of storms skew the monthly mean values upward, and the effects of land and water use tend to skew the daily mean values downward (Lang, 1999).

Other methods may use different time steps in calculating an "August median flow" statistic. For example, Ries (1997A) calculated an "August median-flow" statistic as the median of the daily mean flows of all August days during the entire period of record. To make this calculation, the daily mean flows for August were combined for all August days (31 daily mean flows from each year analyzed), the entire set of flows was ranked, and the median value was identified. Another "Augustmedian-flow" statistic can be calculated from monthly flow durations. In this study, this statistic is refered to as the median $\mathrm{Q}_{50}$ for August. Apse (2000), the Rhode Island Water Resources Board (2003), and the Rhode Island Department of Environmental Management (A. Richardson, Rhode Island Department of Environmental Management, May 2003) have referred to this statistic as the median of the August-median flows. To calculate the median $\mathrm{Q}_{50}$ for August, monthly flow durations are calculated for each month of August for each year of study, the list of $\mathrm{Q}_{50}$ discharges (one from each August for the period of study) is ranked, and a median is identified. Although each of these three statistics may be referred to as an "August median flow," they provide slightly different information, and are not equivalent.

\section{Streamflow Requirements Determined from Hydrologic Records}

Flow management targets determined by use of the RVA and streamflow requirements determined by use of the Tennant and $\mathrm{ABF}$ methods were calculated for index stations on the basis of 25 years of flow records from 1976-2000.

\section{Range of Variability Approach}

Flow-management targets were calculated for mean monthly flows and other ecologically relevant flow indices for the four different geographic regions and for the HF and LF groups (table 11). Mean monthly flows are given for November-May for the four different geographic regions, and for June-October for the HF and LF groups. The range of flowmanagement targets identified by the RVA method for the summer months of July, August, and September, determined by use of the lowest 25 th percentile and highest 75 th percentile for these months, ranged between 0.21 and $0.84 \mathrm{ft}^{3} / \mathrm{s} / \mathrm{mi}^{2}$ for the LF group, and between 0.37 and $1.27 \mathrm{ft}^{3} / \mathrm{s} / \mathrm{mi}^{2}$ for the HF group.

These ranges of flows correspond to average annual exceedance probabilities of 89 and 60 percent for the LF group, and 89 and 54 percent for the HF group.

Results of the IHA analysis for the period 1976-2000, normalized by drainage area, are given in table 18 (back of the report) for six stations that have a median monthly flowduration curve close to the median monthly flow-duration curve for their respective groups. These include Wood River (South coastal group), Little River (South-central group), Squannacook River (North-central group), Green River in Williamstown (Northwest group), Branch River (HF group), and South River (LF group).

\section{Tennant Method}

The $\mathrm{Q}_{\mathrm{MA}}$ and percentages of the $\mathrm{Q}_{\mathrm{MA}}$, normalized by drainage area, used by the Tennant method (Tennant, 1976) to determine streamflow requirements for habitat protection, are summarized in table 12 for 23 index stations in southern New England. The median 40-, 30-, and 10-percent $\mathrm{Q}_{\mathrm{MA}}$ values, representing good, fair, and poor summer habitat conditions, respectively, according to Tennant (1976), were $0.81,0.61$, and $0.20 \mathrm{ft}^{3} / \mathrm{s} / \mathrm{mi}^{2}$.

When divided into the HF and LF groups, the median Tennant 40-, 30-, and 10-percent $\mathrm{Q}_{\mathrm{MA}}$ values, representing good, fair, and poor summer habitat conditions, respectively, according to Tennant (1976), were $0.77,0.58$, and $0.19 \mathrm{ft}^{3} / \mathrm{s} / \mathrm{mi}^{2}$, for the LF group, and $0.83,0.62$, and $0.21 \mathrm{ft}^{3} / \mathrm{s} / \mathrm{mi}^{2}$, for the HF group. These normalized flows correspond to average annual flow durations of 62,70 , and 91 percent exceedance for the LF group, and 69, 77, and 89 percent exceedance for the HF group. The Canadian Atlantic Provinces 25-percent $\mathrm{Q}_{\mathrm{MA}}$ method resulted in streamflow requirements of $0.48 \mathrm{ft}^{3} / \mathrm{s} / \mathrm{mi}^{2}$ for the LF group, and $0.52 \mathrm{ft}^{3} / \mathrm{s} / \mathrm{mi}^{2}$ for the HF group, corresponding to average annual flow durations of 73 percent exceedance for the LF group, and 82 percent exceedance for the HF group. Dividing the stations into the HF and LF groups makes only minor differences in the magnitudes of the streamflow requirements required by the Tennant method, possibly because the mean annual flow is determined more by high flows than by low flows, and because the magnitude of high flows is largely a function of drainage area. 


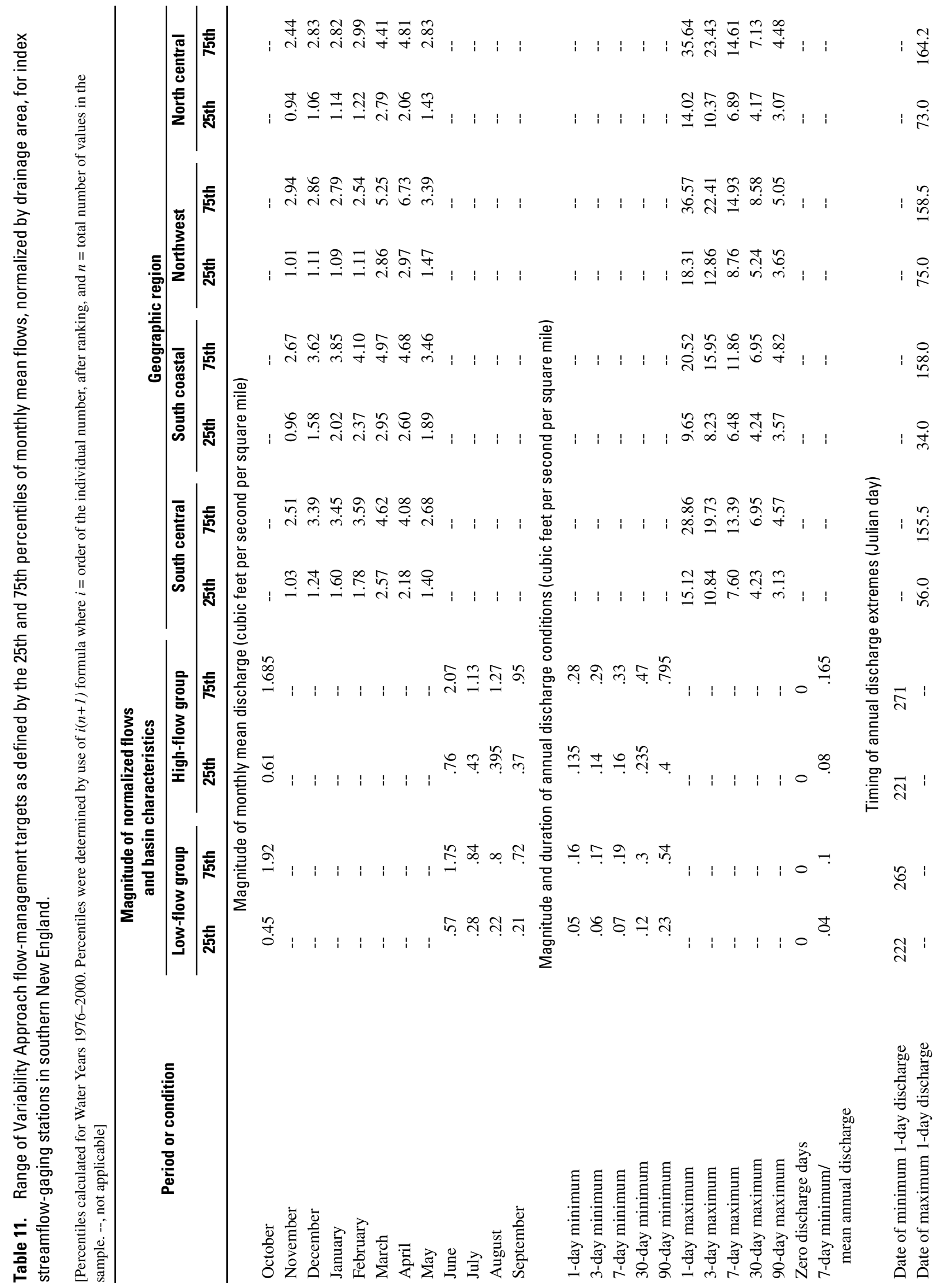




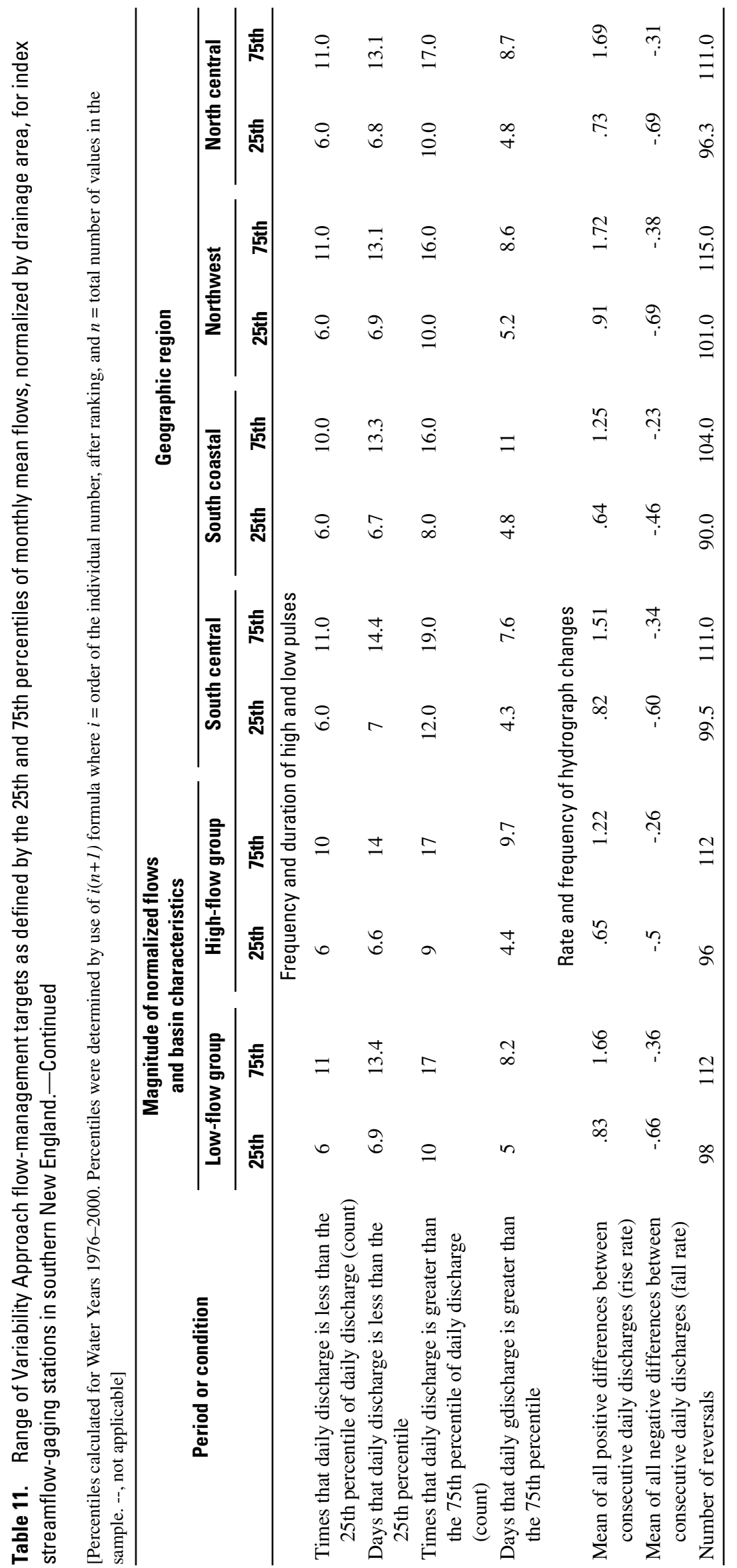


Table 12. The mean annual-flow statistic used by the Tennant and Canadian Atlantic Provinces methods and the streamflows representing summer habitat conditions determined by percentages of the mean annual flow, normalized for drainage area, at 23 index stations in southern New England.

[For relation between aquatic habitat condition and percentages of mean annual flow, see table 9; 25 percent, Streamflow requirement used in the Canadian Atlantic Provinces Method. USGS, U.S. Geological Survey; $\mathrm{ft}^{3} / \mathrm{s}$, cubic foot per second; $\mathrm{ft}^{3} / \mathrm{s} / \mathrm{mi}^{2}$, cubic foot per second per square mile]

\begin{tabular}{|c|c|c|c|c|c|c|c|c|c|c|}
\hline \multirow{3}{*}{ River } & \multirow{3}{*}{ Location } & \multirow{3}{*}{$\begin{array}{c}\text { USGS } \\
\text { station } \\
\text { number }\end{array}$} & \multirow{2}{*}{\multicolumn{2}{|c|}{$\begin{array}{l}\text { Mean annual } \\
\text { flow }\end{array}$}} & \multicolumn{6}{|c|}{ Percentages of mean annual flow } \\
\hline & & & & & \multicolumn{5}{|c|}{$\begin{array}{l}\text { Tennant method } \\
\left(\mathrm{ft}^{3} / \mathrm{s} / \mathrm{mi}^{2}\right)\end{array}$} & \multirow{2}{*}{$\begin{array}{c}\text { Canadian } \\
\text { Atlantic } \\
\text { Provinces } \\
\text { method } \\
\left(\mathrm{ft}^{3} / \mathrm{s} / \mathrm{mi}^{2}\right) \\
25\end{array}$} \\
\hline & & & $\mathrm{ft}^{3} / \mathrm{s}$ & $\mathrm{ft}^{3} / \mathrm{s} / \mathrm{mi}^{2}$ & 50 & 40 & 30 & 20 & 10 & \\
\hline Oyster River & Durham, NH & 01073000 & 19.6 & 1.62 & .81 & .65 & .49 & .32 & .16 & .40 \\
\hline Salmon Creek & Lime Rock, CT & 01199050 & 48.7 & 1.66 & .83 & .66 & .50 & .33 & .17 & .41 \\
\hline Priest Brook & Winchendon, MA & 01162500 & 33 & 1.70 & .85 & .68 & .51 & .34 & .17 & .43 \\
\hline Sevenmile River & Spencer, MA & 01175670 & 15.1 & 1.74 & .87 & .70 & .52 & .35 & .17 & .43 \\
\hline Branch River & Forestdale, RI & 01111500 & 175 & 1.92 & .96 & .77 & .58 & .38 & .19 & .48 \\
\hline Green River & Williamstown, MA & 01333000 & 82.1 & 1.93 & .96 & .77 & .58 & .39 & .19 & .48 \\
\hline Stony Brook tributary & Temple, NH & 01093800 & 7.3 & 2.03 & 1.01 & .81 & .61 & .41 & .20 & .51 \\
\hline Hubbard River & West Hartland, CT & 01187300 & 40.4 & 2.03 & 1.02 & .81 & .61 & .41 & .20 & .51 \\
\hline Old Swamp River & $\begin{array}{l}\text { South Weymouth, } \\
\text { MA }\end{array}$ & 01105600 & 9.18 & 2.04 & 1.02 & .82 & .61 & .41 & .20 & .51 \\
\hline $\begin{array}{l}\text { West Branch } \\
\text { Westfield River }\end{array}$ & Huntington, MA & 01181000 & 192 & 2.04 & 1.02 & .82 & .61 & .41 & .20 & .51 \\
\hline Burlington Brook & Burlington, $\mathrm{CT}$ & 01188000 & 8.41 & 2.05 & 1.03 & .82 & .62 & .41 & .21 & .51 \\
\hline Beaver River & Usquepaug, RI & 01117468 & 21.3 & 2.40 & 1.20 & .96 & .72 & .48 & .24 & .60 \\
\hline Median & & & & 2.03 & 1.01 & .81 & .61 & .41 & .20 & .51 \\
\hline Mean & & & & 1.96 & .98 & .78 & .59 & .39 & .20 & .49 \\
\hline
\end{tabular}




\section{New England Aquatic-Base-Flow Method}

The ABF method requires that August median flow criteria be applied only to index stations that have a drainage area greater than $50 \mathrm{mi}^{2}$. Of the 23 index stations used in this study, only 5 had drainage areas greater than $50 \mathrm{mi}^{2}$ (Branch River, RI; North River, MA; Squannacook River, MA; Salmon River, CT; and West Branch Westfield River, MA). The medians of the monthly mean streamflows for August were calculated for each of these five stations for comparison with the ABF default flows (table 10). For these five stations, the average medians of monthly mean flow, normalized by drainage area, were $0.48 \mathrm{ft}^{3} / \mathrm{s} / \mathrm{mi}^{2}$ for August, $2.2 \mathrm{ft}^{3} / \mathrm{s} / \mathrm{mi}^{2}$ for February, and $3.2 \mathrm{ft}^{3} / \mathrm{s} / \mathrm{mi}^{2}$ for April and May. The summer value of $0.48 \mathrm{ft}^{3} / \mathrm{s} / \mathrm{mi}^{2}$ is identical to that determined by the USFWS for 48 streamflow-gaging stations throughout New England (Lang, 1999). The higher fall/winter and lower spring values calculated for the 5 index stations in southern New England, relative to the ABF default flows, are likely a result of differences in seasonal snowpack between the 5 southern New England stations and the 48 stations used by the USFWS, which included many stations with large drainage areas in northern New England.

If the index stations are divided into two groups for the purposes of evaluating summer flows, as was done in the monthly flow-duration analysis, the Branch River (01111500) is the only index station in the HF group meeting the $\mathrm{ABF}$ $50-\mathrm{mi}^{2}$ drainage-area requirement. The median of August mean streamflow for Branch River, required by the $\mathrm{ABF}$ method for a summer streamflow requirement, was $0.57 \mathrm{ft} 3 / \mathrm{s} / \mathrm{mi}^{2}$. This corresponds to an annual flow duration of 78 percent. The median of August mean streamflow for the remaining four index stations in the LF group that meet the ABF 50-mi ${ }^{2}$ drainage-area requirement (North, Salmon, Squannacook, and West Branch Westfield Rivers) averaged $0.45 \mathrm{ft}{ }^{3} / \mathrm{s} / \mathrm{mi}^{2}$. This corresponds to an average annual flow duration of 76 percent.

For purposes of comparison, the median of monthly mean flows for August, normalized by drainage area, for all 23 index stations, averaged $0.47 \mathrm{ft}^{3} / \mathrm{s} / \mathrm{mi}^{2}$. If the 23 index stations are divided into the HF and LF groups, the normalized median of monthly mean flows for August averaged $0.64 \mathrm{ft} / \mathrm{s} / \mathrm{mi}^{2}$ for the $\mathrm{HF}$ group, and $0.41 \mathrm{ft}^{3} / \mathrm{s} / \mathrm{mi}^{2}$ for the LF group.

\section{Methods for Determining Streamflow Requirements Based on Hydraulic Ratings}

Field data collected at riffles near 10 index stations were used for determining streamflow requirements by use of the Wetted-Perimeter and R2Cross methods. The R2Cross and Wetted-Perimeter methods have also been called mid-range standard-setting instream-flow techniques (mid-range between incremental methods and methods based on hydrologic records) because they have a predetermined process for determining streamflow requirements, but also require site-specific physical and hydraulic data (Instream Flow Council, 2002). The methods require detailed channel-geometry data from stream cross sections in a riffle habitat. These cross-section data, together with additional cross sections surveyed downstream of the riffle and measurements of water depths in the reach over a range of discharges, are used to develop and calibrate a stepbackwater flow model. The flow model is then used to simulate the physical and hydraulic data in the riffle needed to meet the criteria required by the $\mathrm{R} 2 \mathrm{Cross}$ and Wetted-Perimeter methods.

Application of the R2Cross and Wetted-Perimeter methods requires careful selection of appropriate study sites. Both methods must be applied in riffle habitats. A riffle is a section of channel, usually between pools, with gravel, cobble, or boulder bed material. The water surface in riffles is turbulent with little or no white water and has average water velocities in the range of $0.6 \mathrm{ft} / \mathrm{s}$ to $1.6 \mathrm{ft} / \mathrm{s}$ (Bain and Stevenson, 1999).

Riffles are important habitats because of their sensitivity to low flows. During declining flows, riffles are among the first reaches to show habitat losses or to develop fish-passage problems. Appropriate riffles for application of the R2Cross and Wetted-Perimeter methods are in relatively straight river reaches, extend across the entire channel, are well defined, and maintain hydraulic section control (control the upstream river stage) over a range of flows.

Differences in channel geometry among riffles can create variability in Wetted-Perimeter and R2Cross streamflow requirements. Care must be taken to choose sites that are representative of natural riffle conditions. The methods work best in riffles in alluvial rivers. Natural width and depth adjustments of river channels can be influenced by bedrock, uncommonly large boulders, or woody debris in the channel or banks. Where possible, riffle reaches with these features should be avoided for Wetted-Perimeter and R2Cross analysis. Anthropogenic alterations to channels, such as channelization or the reinforcement of streambanks and streambeds with rip rap, can also have an effect on streamflow recommendations resulting from these methods. The artificial widening or narrowing of stream channels can affect wetted perimeter, mean velocity, and mean depth at a site. Consequently, streamflow requirements determined for natural riffle sites may not be sufficient to protect habitat at sites in a widened channel, and flow requirements estimated at sites with a narrowed channel may not provide sufficient flows for habitat protection in unaltered stream reaches.

\section{Water-Surface-Profile Modeling}

Application of the Wetted-Perimeter and R2Cross methods requires development of a stage-discharge relation for a riffle and determination of three hydraulic parameters (mean depth, mean velocity, and wetted perimeter) for a range of 
flows. Manning's equation can be used to develop stagedischarge relations for a single cross section. Manning's equation is:

$$
Q=(1.486 / n) A R^{0.67} S^{0.50}
$$

where

$Q$ is discharge, in $\mathrm{ft}^{3} / \mathrm{s}$;

1.486 is the conversion factor for use with English units;

$n$ is the Manning's roughness coefficient;

$A$ is the cross-sectional area of the channel, in $\mathrm{ft}^{2}$;

$R$ is the hydraulic radius, in $\mathrm{ft}$; and

$S$ is the energy gradient (approximated by the friction slope, $S_{f}$ ), in $\mathrm{ft} / \mathrm{ft}$.

One requirement for application of Manning's equation is a condition of uniform flow. Conditions that can disrupt uniform flow include bends in the stream course, changes in cross-section geometry, obstructions to flow caused by large roughness elements (sand or gravel bars, boulders, woody debris), or other channel features that cause convergence, divergence, acceleration, or deceleration of flow. The equation is not appropriate for evaluating rapidly varied, unsteady flow. Nonuniform-flow conditions can be evaluated for gradually varying flows by use of a one-dimensional, steady-state, stepbackwater, water-surface-profile model. A water-surfaceprofile model that simulates conditions for multiple cross sections provides improved simulations of the hydraulic conditions expected in riffles and can also identify backwater effects not accounted for by single-section applications of Manning's equation.

Stage, discharge, Manning's $n$, and water-surface slopes were determined for this report primarily by use of the U.S. Army Corps of Engineers' River Analysis System (HEC-RAS; Brunner, 2001). HEC-RAS is designed to perform onedimensional hydraulic calculations for a network of natural or constructed channels under steady or gradually varied flow. The computational procedure is based on the solution of the onedimensional energy equation from one stream section to the next. Energy losses are evaluated by friction (Manning's equation) and channel contraction or expansion (Brunner, 2001).

Field-data collection for the Wetted-Perimeter and R2Cross analyses included surveys of stream-channel cross sections and water-surface slopes within and downstream of riffle habitats. Determinations of the elevations of the bottomof-bank and of bankfull flow were made during the survey. The distance between the cross sections was about one channel width. Staff gages provided vertical control for surveying transect cross-section profiles and water-surface elevations. Landscape nails about $1 \mathrm{ft}$ in length were installed in the streambed at multiple cross sections to provide elevation reference points. Surveys of staff gages, streambed reference nails, channel cross sections and water levels were made with a laser theodolite. Levels were run independently at each site but were not surveyed to local benchmarks. Sites were revisited to measure water-surface elevations over the nails, read staff gages, and take photos. Stream discharge was determined from the rating curves for each streamflow-gaging station.

Data from the channel surveys and stream-discharge measurements were used to develop HEC-RAS models for each study site. To determine an initial value for channel roughness ( $n$ ) for use in the model, Manning's equation (eq. 1) was solved for each cross section by use of stream discharge, surveyed channel areas and water-surface slope values. Water-surface slope was then used as a boundary condition and Manning's $n$ was varied with depth to calibrate the model to the measured water levels and discharges.

Once calibrated, the HEC-RAS model is used to simulate the water-surface profile over wide ranges of discharge, and to simulate the other hydraulic parameters required for application of the R2Cross and Wetted-Perimeter methods. The R2Cross and Wetted-Perimeter methods are applied only to cross sections in riffle habitats and should not be applied to cross sections in other habitats such as pools or runs. Transitions to these habitats at the upstream end of the riffle are also avoided for analysis. Although many cross sections are surveyed in a riffle and for several channel widths downstream for use in the HEC-RAS model, only those in the portion of the riffle that is above backwater effects from downstream are used for R2Cross and Wetted-Perimeter analysis.

Data simulated by the calibrated HEC-RAS model are used to calculate Wetted-Perimeter and R2Cross streamflow requirements. Wetted-Perimeter streamflow requirements are determined from HEC-RAS output plots of wetted perimeter and discharge, stream cross sections, and plots of wetted perimeter and surface-water elevations where the elevation of the bottom-of-bank has been identified. R2Cross streamflow requirements are determined from a HEC-RAS output table showing discharges, water-surface elevations, stream topwidth, average depth, average velocity, and the percent of bankfull wetted perimeter over a range of flows.

One-dimensional flow models are near their limits for use when modeling low flows. One-dimensional flow models assume that velocity vectors and water-surface elevations are the same at all points in a cross section. As flows drop in riffle habitats, the exposure of streambed substrate (cobble, boulders) or bed features (gravel bars, woody debris) can create variability in stream-velocity vectors and differences in water surface elevations within a cross section. Therefore, calibration of a one-dimensional flow model over a range of flows frequently requires use of extremely high roughness coefficients at the lower flows to compensate for the lengthened flow lines beyond the straight-line distance between consecutive cross sections. The values for Manning's $n$ may appear unrealistic to modelers accustomed to simulating high flows. The HEC-RAS models used in this study were calibrated to observed water-surface conditions. Model simulations were initiated several cross sections downstream of the study reach to eliminate boundary effects on the calibration process. The 
calibrated models were assumed to adequately simulate hydraulic conditions in the study reaches for the purpose of this report.

\section{Wetted-Perimeter Method}

The Wetted-Perimeter method is based on the assumption that there is a direct relation between the wetted perimeter in a riffle and fish habitat in streams (Annear and Conder, 1984; Lohr, 1993). The wetted perimeter of a stream, defined as the width of the streambed and stream banks in contact with water for an individual cross section (fig. 9A), is used as a measure of the availability of aquatic habitat over a range of discharges (Annear and Conder, 1984; Nelson, 1984). Wetted-Perimeter streamflow requirements are determined primarily from a plot of the relation between wetted perimeter and discharge (fig. 9B). These plots generally have a characteristic shape: steeper at low discharges and flatter at high discharges. Initially, as the channel fills with water, there is a rapid increase in wetted perimeter for each unit increase in discharge. Once water fills the channel to the bottoms of the banks and begins to rise up the streambanks, the rate of increase of wetted perimeter for each unit increase of discharge decreases. This process creates a break in slope in the plot of wetted perimeter and discharge. This break point is used to determine the Wetted-Perimeter streamflow requirement. On a stream cross section, this break point theoretically corresponds to the break in slope at the bottom of a streambank (toe-of-bank) (fig. 9A), where the water surface would begin to rise up the banks when flows increase, or recede in a more horizontal direction from the streambanks when flows decrease.

Stream-channel geometry varies considerably, and the effectiveness of the Wetted-Perimeter method is dependent upon the cross sections selected in the field. The general shapes of plots of wetted perimeter and discharge can be altered by the geometry of the streambanks and channel (rectangular, trapezoidal, rounded, triangular) (Gippel and Stewardson, 1996). The break in slope is most distinct in riffle channels with rectangular or trapezoidal cross sections that also have sharp breaks in slope between the streambed and streambanks. In these channels, water levels that rise above the bottom of the bank cause smaller rates of increase in wetted perimeter, and water levels that fall below the bottom of the bank cause larger rates of decrease in wetted perimeter. In practice, there is seldom a single break in slope in the wetted-perimeter-todischarge relation; many conditions contribute to multiple breaks in slope or the lack of a distinct break point. Multiple break points can correspond to water rising over channel features such as bars and boulders, or an irregular channel bed or banks. Less well-defined break points may also be a function of the number, density, and location of points surveyed along a cross section.

For this study, several detailed cross sections were surveyed at each riffle site. Points along the cross section that corresponded to changes in slope of the streambeds and banks were surveyed. The altitudes of bankfull indicaters were identified and surveyed, along with the bottoms of the streambanks, and the corresponding width of the channel between the left and right bottom-of-bank (the fully wettedchannel bottom width). To improve consistency in use of the Wetted-Perimeter method, a systematic procedure for selection of cross sections, surveying, and determination of break points was developed (Appendix 2).

\section{R2Cross Method}

The R2Cross method is based on the assumption that a discharge chosen to maintain habitat in a riffle is sufficient to maintain habitat in nearby pools and runs for most life stages of fish and aquatic invertebrates (Nehring, 1979). R2Cross streamflow requirements for habitat protection in riffles are determined from flows that meet criteria for three hydraulic parameters: mean depth, percent of bankfull wetted perimeter, and average water velocity (table 13). Criteria for these hydraulic variables were developed in Colorado to quantify the amount of streamflow required to "preserve the natural environment to a reasonable degree" (Espegren, 1996). The depth criterion requires a mean depth that is at least $1 / 100$ of the bankfull stream-top width, and has a lower limit of $0.2 \mathrm{ft}$. The wetted-perimeter criterion requires a wetted perimeter that is at least 50 percent of the bankfull wetted perimeter for streams less than $50 \mathrm{ft}$ wide, equal to the top width (to the nearest foot) for streams between 51 and $60 \mathrm{ft}$ wide, or 70 percent of the bankfull wetted perimeter for streams wider than $60 \mathrm{ft}$ (G. Espegren, Colorado Water Conservation Board, written commun., 2001). The velocity criterion requires an average velocity of at least $1 \mathrm{ft} / \mathrm{s}$. 
A.

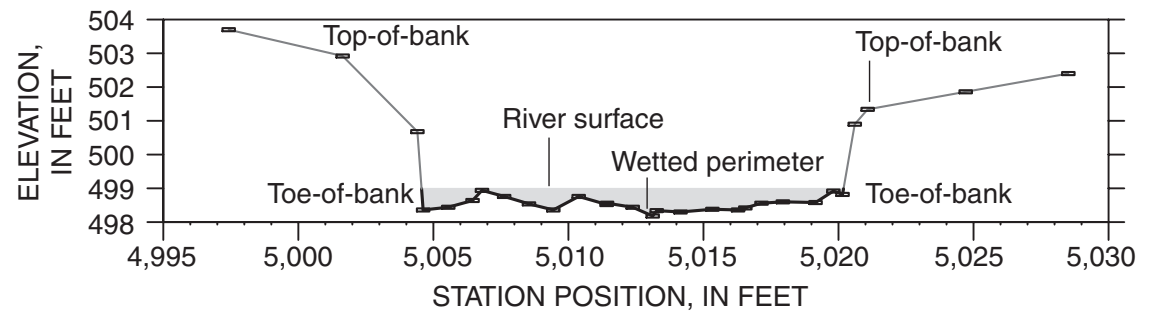

B.

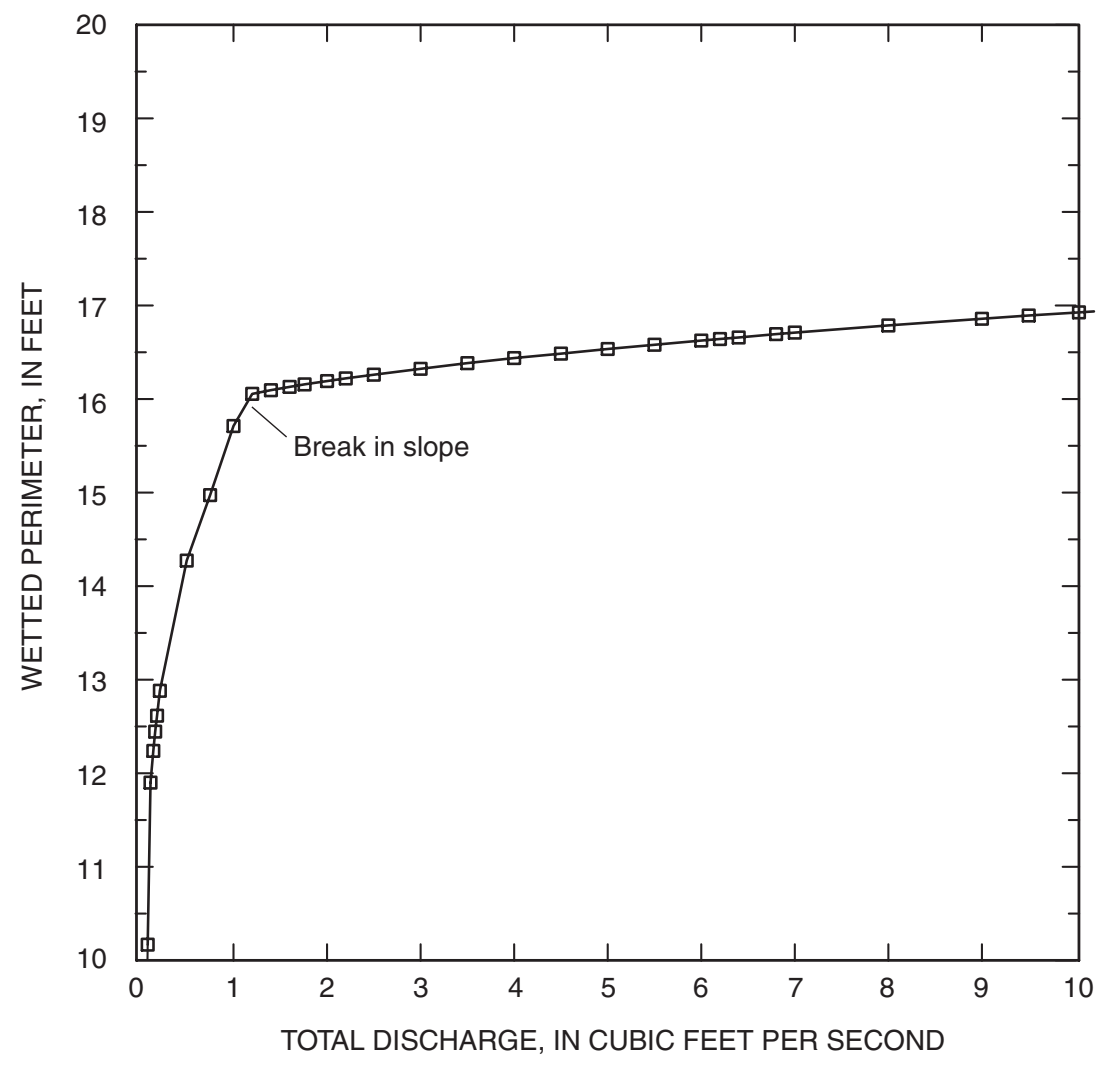

Figure 9. Schematic showing $A$, cross section of stream channel; and $B$, relation between wetted perimeter and discharge. 
Table 13. Hydraulic criteria for determination of R2Cross streamflow requirements for habitat protection.

[Source: Modified from Espegren, 1996. ft, foot; ft/s, foot per second; $\geq$, actual value is greater than or equal to the value shown]

\begin{tabular}{cccc}
\hline $\begin{array}{c}\text { Bankfull } \\
\text { stream-top } \\
\text { width } \\
\text { (ft) }\end{array}$ & $\begin{array}{c}\text { Mean depth } \\
\text { (ft) }\end{array}$ & $\begin{array}{c}\text { Percentage of } \\
\text { bankfull wetted } \\
\text { perimeter } \\
\text { (percent) }\end{array}$ & $\begin{array}{c}\text { Mean velocity } \\
\text { (ft/s) }\end{array}$ \\
\hline $1-20$ & 0.2 & 50 & 1.0 \\
$21-50$ & $0.2-0.5$ & 50 & 1.0 \\
$51-60$ & $0.5-0.6$ & $50-60$ & 1.0 \\
$61-100$ & $0.6-1.0$ & $\geq 70$ & 1.0 \\
\hline
\end{tabular}

To account for seasonal streamflow variability, the R2Cross method, as developed in Colorado, established different streamflow requirements for the summer and winter seasons (Espegren, 1996). Summer R2Cross streamflow recommendations in Colorado are based upon the streamflow that meets all three hydraulic criteria (depth, velocity, and wetted perimeter). Colorado winter R2Cross streamflow recommendations are lower streamflows based upon the streamflow that meets any two of the three hydraulic criteria (the criterion associated with the highest discharge for each cross section is dropped). This study evaluated the use of both the R2Cross 3-of-3 and 2-of-3 criteria methods for determining summer streamflow recommendations in Massachusetts. Unlike mountain-runoff streams in Colorado, streamflows in Massachusetts are generally lowest in midsummer and early fall (July-September) and may have additional stresses during summer months that are linked to these low streamflows, such as high stream temperatures and low dissolved oxygen concentrations.

\section{Streamflow Requirements Determined from Hydraulic Ratings}

Riffle reaches near 10 index stations were selected for investigation of summer streamflow requirements by use of the Wetted-Perimeter and R2Cross methods (tables 4 and 14). The drainage areas to the stations represent a range of geographic areas and basin characteristics. The sites included six sites in Massachusetts, two sites in Connecticut, and one site each in Rhode Island and New Hampshire. Descriptions of the study reaches, reach surveys, and discharges used for calibration of HEC-RAS models for each site are included in Appendix 3. The appendix also includes tables of the hydraulic variables simulated by the calibrated HEC-RAS models for individual cross sections at each site that met the R2Cross and WettedPerimeter criteria for determining summer streamflow requirements.
Table 14. Average streamflow requirements determined by the Wetted-Perimeter method for 10 index streamflow-gaging stations in southern New England.

[Site: Locations are shown in figure 1. Group: HF, high-flow group; LF, lowflow group. $\mathrm{ft}^{3} / \mathrm{s}$, cubic foot per second; $\mathrm{ft}^{3} / \mathrm{s} / \mathrm{mi}^{2}$ ), cubic foot per second per square mile]

\begin{tabular}{|c|c|c|c|c|}
\hline Site & Group & $\begin{array}{c}\text { Discharge } \\
\left(\mathrm{ft}^{3} / \mathrm{s}\right)\end{array}$ & $\begin{array}{c}\text { Discharge } \\
\text { per unit } \\
\text { drainage } \\
\text { basin } \\
\text { area } \\
\left(\mathrm{ft}^{3} / \mathrm{s} / \mathrm{mi}^{2}\right)\end{array}$ & $\begin{array}{c}\text { Annual } \\
\text { flow } \\
\text { duration } \\
\text { (percent } \\
\text { exceed- } \\
\text { ance) }\end{array}$ \\
\hline Squannacook River, MA & LF & 22.5 & 0.35 & 79 \\
\hline Beaver Brook, NH & $\mathrm{LF}$ & 6.30 & .13 & 88 \\
\hline Old Swamp River, MA & $\mathrm{LF}$ & 2.18 & .48 & 75 \\
\hline Wood River, RI & $\mathrm{HF}$ & 11.7 & .33 & 95 \\
\hline Mount Hope River, CT & $\mathrm{LF}$ & 13.8 & .48 & 70 \\
\hline Little River, CT & $\mathrm{LF}$ & 12.0 & .40 & 82 \\
\hline South River, MA & $\mathrm{LF}$ & 6.67 & .28 & 92 \\
\hline $\begin{array}{l}\text { Green River-Colrain, } \\
\text { MA }\end{array}$ & LF & 24.0 & .58 & 72 \\
\hline Sevenmile River, MA & LF & 3.40 & .39 & 75 \\
\hline $\begin{array}{l}\text { Green River- } \\
\text { Williamstown, MA }\end{array}$ & LF & 13.7 & .32 & 86 \\
\hline \multicolumn{3}{|l|}{ Median } & 0.37 & 81 \\
\hline \multicolumn{3}{|c|}{ Median for low-flow group of stations } & 0.39 & 79 \\
\hline
\end{tabular}

\section{Wetted-Perimeter Method}

The streamflow required by the Wetted-Perimeter method for each riffle site was calculated by averaging the streamflow requirements for several critical cross sections within the riffles. Normalized Wetted-Perimeter streamflow requirements for the 10 index stations ranged between 0.13 and $0.58 \mathrm{ft}^{3} / \mathrm{s} / \mathrm{mi}^{2}$ (table 14). The median streamflow requirement for the ten index stations was $0.37 \mathrm{ft}^{3} / \mathrm{s} / \mathrm{mi}^{2}$.

The index stations were divided into two groups for the purposes of evaluating flows during the low-flow season (JuneOctober), as was done in the monthly flow-duration analysis. The median streamflow requirement for the nine index stations in the LF group was $0.39 \mathrm{ft}^{3} / \mathrm{s} / \mathrm{mi}^{2}$, corresponding to an average annual flow duration of 80 percent. The Wood River index site (01117800) is the only one in the HF group to which the Wetted-Perimeter method was applied. The streamflow requirement for the Wood River site was $0.33 \mathrm{ft}^{3} / \mathrm{s} / \mathrm{mi}^{2}$. This corresponds to an annual flow duration of 95 percent.

Some of the variation in the streamflow requirements at the sites can be explained by variability in channel geometry. The method seems to provide more consistent results for 
alluvial channels that can adjust their width, depth, and slope. Bedrock in the channel can modify channel shape and potentially increase the variability of the results. Bedrock was exposed in the channel near the riffle study reaches for Green River near Colrain, Beaver Brook, Squannacook River, and Green River at Williamstown. Two of these reaches, Green River near Colrain and Beaver Brook, had the highest and lowest streamflow requirements, respectively, that were determined by the Wetted-Perimeter method. The stream channel at the riffle study site on the Green River near Colrain is a long straight reach and is quite wide relative to its drainage area, possibly because of a shallow depth to bedrock beneath the streambed. The bedrock could potentially restrict the river from deepening, resulting in a wider channel. Application of the Wetted-Perimeter method to a wider flow channel typically results in a higher streamflow requirement. The Beaver Brook riffle site is on a river bend with bedrock along the left outside bank. The bedrock could potentially prevent the river from widening, resulting in a narrow incised channel. Application of the Wetted-Perimeter method to a narrower channel typically results in a lower streamflow requirement.

\section{R2Cross Method}

Streamflow requirement were calculated by the R2Cross 3-of-3 and 2-of-3 criteria methods. The requirements for each riffle study site were determined by averaging the streamflow requirements for several cross sections within the riffles. The streamflow requirements identified by the two R2Cross criteria exhibited a wide degree of variation among sites. Normalized streamflows that met the R2Cross 3-of-3 criteria ranged from 0.39 to $2.1 \mathrm{ft}^{3} / \mathrm{s} / \mathrm{mi}^{2}$ and had a median streamflow requirement of $0.78 \mathrm{ft}^{3} / \mathrm{s} / \mathrm{mi}^{2}$ (table 15). Normalized streamflows that met the R2Cross 2-of-3 criteria ranged between 0.16 and $0.85 \mathrm{ft}^{3} / \mathrm{s} / \mathrm{mi}^{2}$, and had a median streamflow requirement of $0.36 \mathrm{ft}^{3} / \mathrm{s} / \mathrm{mi}^{2}$.

The median streamflow requirements from the R2Cross 3-of-3 and 2-of-3 criteria methods for the nine index stations in the LF group were $0.84 \mathrm{ft}^{3} / \mathrm{s} / \mathrm{mi}^{2}$ and $0.35 \mathrm{ft}^{3} / \mathrm{s} / \mathrm{mi}^{2}$, respectively. These flows correspond to average annual flow durations of 60 percent exceedance and 82 percent exceedance, respectively. Wood River was the only site in the HF group to which the R2Cross method was applied. The requirements for the Wood River site for the R2Cross 3-of-3 and 2-of-3 criteria methods were $0.73 \mathrm{ft}^{3} / \mathrm{s} / \mathrm{mi}^{2}$, and $0.49 \mathrm{ft}^{3} / \mathrm{s} / \mathrm{mi}^{2}$, respectively. These flows correspond to annual flow durations of 73 and 89 percent, respectively.

The R2Cross method relates discharge to specific criteria for percentage of bankfull wetted perimeter, mean depth, and average velocity in a channel cross section. When applying the R2Cross 3-of-3 and 2-of-3 criteria methods, mean velocity was most often the criterion that was met at the highest discharge, and was therefore the most limiting of the three criteria for determining the R2Cross streamflow requirement. Mean velocity was the limiting criterion for 74 percent of the 31 riffle cross sections, and mean depth was the limiting criterion for 26 percent of the cross sections. The second R2Cross criterion to be met was generally mean depth. Mean depth was the second limiting criterion for 68 percent of the 31 cross sections, mean velocity was the second limiting factor for 22 percent of the cross sections, and percentage of bankfull wetted perimeter was the second limiting factor for 10 percent of the cross sections.

To evaluate differences between the R2Cross 3-of-3 and R2Cross 2-of-3 criteria methods, mean velocities and mean depths were compared for each of the cross sections in the study riffles. Mean velocity was most often the last criterion to be met for the R2Cross 3-of-3 criteria method, and consequently, the median value for the 31 cross sections was $1.0 \mathrm{ft} / \mathrm{s}$. The mean velocity associated with R2Cross 2 -of-3 criteria streamflow requirement had a median value of $0.76 \mathrm{ft} / \mathrm{s}$ for the 31 cross sections. Mean depths should not be compared between sites unless the mean depth values are normalized to account for differences in drainage area among the 10 index stations. Comparison of mean depths associated with streamflows identified by the R2Cross 3-of-3 and 2-of-3 criteria methods for individual sites shows that the mean depths tended to differ by only a few tenths of a foot. For example, for the Sevenmile River, one of the smaller rivers investigated in this study with a drainage area of $8.81 \mathrm{mi}^{2}$, the R2Cross 3-of-3 criteria method identified a streamflow requirement for habitat protection of $3.43 \mathrm{ft}^{3} / \mathrm{s}\left(0.39 \mathrm{ft}^{3} / \mathrm{s} / \mathrm{mi}^{2}\right)$, and the R2Cross 2-of-3 criteria method identified a streamflow of $1.4 \mathrm{ft}^{3} / \mathrm{s}\left(0.16 \mathrm{ft}^{3} / \mathrm{s} / \mathrm{mi}^{2}\right)$. The mean depths associated with these two flows, $0.27 \mathrm{ft}$ and $0.2 \mathrm{ft}$, respectively, differ by less than $0.1 \mathrm{ft}$. In contrast, for the Squannacook River, one of the larger rivers investigated in this study, the R2Cross 3-of-3 criteria method identified a streamflow of $34.2 \mathrm{ft}^{3} / \mathrm{s}\left(0.54 \mathrm{ft}^{3} / \mathrm{s} / \mathrm{mi}^{2}\right)$, and the R2Cross R2Cross 2-of-3 criteria method identified a streamflow of $17.2 \mathrm{ft}^{3} / \mathrm{s}\left(0.27 \mathrm{ft}^{3} / \mathrm{s} / \mathrm{mi}^{2}\right)$. The mean depths associated with these two flows, $0.62 \mathrm{ft}$ and $0.48 \mathrm{ft}$, respectively, differ by only $0.14 \mathrm{ft}$.

Part of the process of applying the R2Cross method requires determination of channel top-width at bankfull flow. The discharges corresponding to field-identified bankfull flows were simulated by HEC-RAS modeling (table 16). Because the riffles were near streamflow gaging stations, the flow durations corresponding to these flows could be determined. These flow durations could be useful to provide rough estimates of bankfull flows at ungaged sites. Bankfull flow at the 10 riffle sites had a median flow duration of 10 percent. This is within the range of flow durations corresponding to bankfull indicators identified by other investigators (N.M. Hurley, Jr., oral commun., U.S. Geological Survey, 2002; G.C. Bent, oral commun., U.S. Geological Survey, 2003; R.W. Dudley, oral commun., U.S. Geological Survey, 2003). 
Table 15. Streamflow requirements and corresponding flow durations determined by the R2Cross method for 10 index streamflowgaging stations in southern New England.

[Site: Locations are shown in figure 1. Group: HF, high-flow group; LF, low-flow group. $\mathrm{ft}^{3} / \mathrm{s}$, cubic foot per second; $\mathrm{ft}^{3} / \mathrm{s} / \mathrm{mi}^{2}$, cubic foot per second per square mile]

\begin{tabular}{|c|c|c|c|c|c|c|c|}
\hline \multirow[b]{2}{*}{ Site } & \multirow[b]{2}{*}{ Group } & \multicolumn{3}{|c|}{ 3-of-3-criteria method } & \multicolumn{3}{|c|}{ 2-of-3-criteria method } \\
\hline & & $\begin{array}{c}\text { Discharge } \\
\left(\mathrm{ft}^{3} / \mathrm{s}\right)\end{array}$ & $\begin{array}{c}\text { Discharge per } \\
\text { unit drainage } \\
\text { basin area } \\
\left(\mathrm{ft}^{3} / \mathrm{s} / \mathrm{mi}^{2}\right)\end{array}$ & $\begin{array}{c}\text { Annual flow } \\
\text { duration } \\
\text { (percent } \\
\text { exceedance) }\end{array}$ & $\begin{array}{c}\text { Discharge } \\
\qquad\left(\mathrm{ft}^{3} / \mathrm{s}\right)\end{array}$ & $\begin{array}{c}\text { Discharge per } \\
\text { unit drainage } \\
\text { basin area } \\
\left(\mathrm{ft}^{3} / \mathrm{s} / \mathrm{mi}^{2}\right)\end{array}$ & $\begin{array}{c}\text { Annual flow } \\
\text { duration } \\
\text { (percent } \\
\text { exceedance) }\end{array}$ \\
\hline Squannacook River, MA & LF & 34.2 & 0.54 & 68 & 17.2 & 0.27 & 86 \\
\hline Beaver Brook, NH & $\mathrm{LF}$ & 18.8 & .39 & 74 & 9.40 & .20 & 85 \\
\hline Wood River, RI & $\mathrm{HF}$ & 25.8 & .73 & 77 & 17.4 & .49 & 87 \\
\hline Mount Hope River, CT & LF & 17.7 & .62 & 65 & 10.0 & .35 & 76 \\
\hline Little River, CT & LF & 28.7 & .96 & 57 & 11.1 & .37 & 85 \\
\hline South River, MA & LF & 22.3 & .92 & 60 & 17.3 & .72 & 68 \\
\hline Green River-Colrain, MA & LF & 88.5 & 2.1 & 29 & 35.0 & .85 & 62 \\
\hline \multicolumn{3}{|c|}{ Median for low-flow group of stations } & 0.84 & 65 & & 0.35 & 84 \\
\hline
\end{tabular}

Table 16. Field-determined bankfull discharges for 10 index streamflow-gaging stations in southern New England.

[ft $\mathrm{ft}^{3} / \mathrm{s}$, cubic foot per second; $\mathrm{ft}^{3} / \mathrm{s} / \mathrm{mi}^{2}$, cubic foot per second per square mile]

\begin{tabular}{|c|c|c|c|}
\hline Site & $\begin{array}{c}\text { Bankfull } \\
\text { discharge } \\
\left(\mathrm{ft}^{3} / \mathrm{s}\right)\end{array}$ & $\begin{array}{c}\text { Discharge } \\
\text { per unit } \\
\text { drainage } \\
\text { basin area } \\
\left(\mathrm{ft}^{3} / \mathrm{s} / \mathrm{mi}^{2}\right)\end{array}$ & $\begin{array}{c}\text { Annual } \\
\text { flow duration } \\
\text { (percent } \\
\text { exceedance) }\end{array}$ \\
\hline Squannacook River, MA & 250 & 3.9 & 10 \\
\hline Beaver Brook, NH & 110 & 2.3 & 20 \\
\hline Old Swamp River, MA & 35 & 7.8 & 04 \\
\hline Wood River, RI & 110 & 3.1 & 22 \\
\hline Mount Hope River, CT & 65 & 2.3 & 25 \\
\hline Little River, CT & 70 & 2.3 & 25 \\
\hline South River, MA & 120 & 5.0 & 09 \\
\hline Green River-Colrain, MA & 220 & 5.3 & 09 \\
\hline Sevenmile River, MA & 35 & 4.0 & 10 \\
\hline $\begin{array}{l}\text { Green River- } \\
\text { Williamstown, MA }\end{array}$ & 200 & 4.7 & 09 \\
\hline Mean & & 3.7 & 17 \\
\hline Median & & 4.0 & 10 \\
\hline
\end{tabular}

The mean depths associated with the median $\mathrm{Q}_{50}$ discharges can be normalized by the mean depth associated with the field-identified bankfull flow as a means of expressing the depths that can be expected in riffle cross sections during the summer months. For nine of the index stations (excluding Old Swamp River), the normalized mean depths for the median $\mathrm{Q}_{50}$ discharge for June through October averaged 0.46, 0.35, 0.32, 0.31 , and 0.41 , respectively. These values suggest that the mean depth of flow in riffle habitats associated with the median $\mathrm{Q}_{50}$ discharge for the low-flow months of July, August, and September would be expected to be approximately one-third of the mean depth associated with bankfull flow at those sites.

Mean depths associated with R2Cross streamflow requirements were compared to the mean depths corresponding to the median $\mathrm{Q}_{50}$ at the index stations in the LF group to evaluate the R2Cross 3-of-3 and 2-of-3 criteria methods. In general, depths identified by the R2Cross 3 -of- 3 criteria method tended to be closest to mean flow depth associated with the median $\mathrm{Q}_{50}$ in June, and depths identified by the R2Cross 2-of3 criteria methods tended to be closest to the mean flow depths associated with the median $\mathrm{Q}_{50}$ in September. Drainage areas, stream slopes, substrate, and channel geometry all influence the depth of flow in riffles, and flow depths in different rivers cannot be directly compared between rivers or cross sections without compensating for these differences. However, the mean 
depths associated with the median $\mathrm{Q}_{50}$ for the summer months can give an indication of the order of magnitude of the flow depths that would be expected in the study riffles during summer. Mean depths associated with median $\mathrm{Q}_{50}$ discharges ranged from about 0.2 to $0.6 \mathrm{ft}$, and mean depths in 5 of the 10 riffles were between 0.3 and $0.4 \mathrm{ft}$. One characteristic of flow in riffles is that a small difference in mean flow depth may correspond to a large difference in flow, in terms of $\mathrm{ft}^{3} / \mathrm{s} / \mathrm{mi}^{2}$. As an example, the mean flow depth corresponding to the median $\mathrm{Q}_{50}$ can be compared for riffles studied in two rivers with similar drainage areas but differing percentages of sand and gravel, Wood River (drainage area of $35.2 \mathrm{mi}^{2}, 23.3$ percent sand and gravel) and Mount Hope River (drainage area of $28.6 \mathrm{mi}^{2}, 4.9$ percent sand and gravel). The median $\mathrm{Q}_{50}$ for these sites for July, August, and September, normalized by drainage area, were $0.71,0.62$, and $0.58 \mathrm{ft}^{3} / \mathrm{s} / \mathrm{mi}^{2}$, respectively, for the Wood River riffle and $0.26,0.24$, and $0.22 \mathrm{ft}^{3} / \mathrm{s} / \mathrm{mi}^{2}$, respectively, for the Mount Hope River riffle. The mean flow depths associated with the median $\mathrm{Q}_{50}$ for July, August, and September were $0.57,0.54$, and $0.52 \mathrm{ft}$ for the Wood River riffle, and $0.36,0.35$, and $0.34 \mathrm{ft}$ for the Mount Hope River riffle, respectively, a difference in mean depth of about $0.2 \mathrm{ft}$.

\section{Evaluation of Streamflow Requirements}

Summer streamflow requirements for habitat protection, computed by standard-setting methods and normalized by drainage area, ranged from 0.19 to $0.84 \mathrm{ft}^{3} / \mathrm{s} / \mathrm{mi}^{2}$ for the $\mathrm{LF}$ group and 0.21 to $0.73 \mathrm{ft}^{3} / \mathrm{s} / \mathrm{mi}^{2}$ for the HF group (table 17). Methods that identified the highest streamflow requirements included the R2Cross 3-of-3 criteria method for stations in the LF group, which had a median of $0.84 \mathrm{ft}^{3} / \mathrm{s} / \mathrm{mi}^{2}$ (table 15), and the Tennant 40-percent $\mathrm{Q}_{\mathrm{MA}}$ method (considered by Tennant to produce a good summer-habitat condition), which had a median of $0.81 \mathrm{ft}^{3} / \mathrm{s} / \mathrm{mi}^{2}$ (table 12). The method that produced the lowest streamflow requirement was the Tennant 10-percent $\mathrm{Q}_{\mathrm{MA}}$, (considered by Tennant to produce a poor summer habitat condition), which had a median of $0.20 \mathrm{ft}^{3} / \mathrm{s} / \mathrm{mi}^{2}$ (table 12). Average annual flow durations corresponding to the summer streamflow requirements for the different methods were determined for the HF and LF groups (table 17). These flow durations were calculated by first using the normalized median streamflow requirement for each method, listed in table 17, and calculating a corresponding discharge for each of the index stations in the group. The annual flow duration corresponding to the discharge for each index station was then determined. Finally, an average annual flow duration was calculated for each method (table 17).

Streamflow requirements determined by the Tennant, $\mathrm{ABF}$, Wetted-Perimeter, and R2Cross methods can be evaluated by comparison to flow statistics from the 23 index stations in southern New England. Streamflow requirements determined by use of the Tennant $0.30 \mathrm{Q}_{\mathrm{MA}}$ method $\left(0.61 \mathrm{ft}^{3} / \mathrm{s} / \mathrm{mi}^{2}\right)$ identify normalized streamflows that are near the median $\mathrm{Q}_{50}$ flow in the summer months for the HF group, but are higher than those of the median $\mathrm{Q}_{50}$ discharges in the summer months for the LF group. For example, the median $\mathrm{Q}_{50}$ for July for rivers in the HF group was $0.57 \mathrm{ft}^{3} / \mathrm{s} / \mathrm{mi}^{2}$, whereas the median $\mathrm{Q}_{50}$ for August for rivers in the LF group was $0.36 \mathrm{ft}^{3} / \mathrm{s} / \mathrm{mi}^{2}$. The median Tennant $0.30 \mathrm{Q}_{\mathrm{MA}}$ streamflow requirement $\left(0.61 \mathrm{ft}^{3} / \mathrm{s} / \mathrm{mi}^{2}\right)$ exceeds the median $\mathrm{Q}_{25}$ for the $\mathrm{LF}$ group for August and September, meaning that streamflows identified by the Tennant $0.30 \mathrm{Q}_{\mathrm{MA}}$ method would occur less than 25 percent of the time for these months. The summer streamflow requirement identified by the Canadian Atlantic Provinces method $\left(0.51 \mathrm{ft}^{3} / \mathrm{s} / \mathrm{mi}^{2}\right)$, falls within the range of flows defined by the median $\mathrm{Q}_{50}$ for July, August, and September for rivers in the HF group $\left(0.57,0.49,0.46 \mathrm{ft}^{3} / \mathrm{s} / \mathrm{mi}^{2}\right.$, respectively), but is higher than the median $\mathrm{Q}_{50}$ for July, August, and September for rivers in the LF group (0.36, 0.28, $0.27 \mathrm{ft}^{3} / \mathrm{s} / \mathrm{mi}^{2}$, respectively).

The ABF median of monthly mean flow for August for four index stations in the LF group with drainage areas greater than $50 \mathrm{mi}^{2}$, normalized by drainage area, averaged $0.45 \mathrm{ft}^{3} / \mathrm{s} / \mathrm{mi}^{2}$ (table 17). For all of the index stations, regardless of drainage area, the median of monthly mean flow for August, normalized by drainage area, averaged $0.64 \mathrm{ft}^{3} / \mathrm{s} / \mathrm{mi}^{2}$ for the HF group, and $0.41 \mathrm{ft}^{3} / \mathrm{s} / \mathrm{mi}^{2}$ for the LF group. These flows, which were calculated from monthly mean flows as required by the ABF method (U.S. Fish and Wildlife Service, 1981) were higher than the monthly $\mathrm{Q}_{50}$ discharges determined for the HF and LF groups for July, August, and September. For the HF group, the median $\mathrm{Q}_{50}$ discharges for June through October were $1.01,0.57,0.49,0.46$, and $0.77 \mathrm{ft}^{3} / \mathrm{s} / \mathrm{mi}^{2}$, respectively. For the LF group, the median $\mathrm{Q}_{50}$ flows for these months were 0.70 , $0.36,0.28,0.27$, and $0.55 \mathrm{ft}^{3} / \mathrm{s} / \mathrm{mi}^{2}$, respectively.

Nine of the 10 study sites where the R2Cross and WettedPerimeter methods were applied were in the LF group. The median streamflow requirements determined by the WettedPerimeter method $\left(0.39 \mathrm{ft}^{3} / \mathrm{s} / \mathrm{mi}^{2}\right)$ and R2Cross 2-of-3 criteria method $\left(0.35 \mathrm{ft}^{3} / \mathrm{s} / \mathrm{mi}^{2}\right)$ identify streamflows that are nearly equivalent to the median $\mathrm{Q}_{50}$ for July $\left(0.36 \mathrm{ft}^{3} / \mathrm{s} / \mathrm{mi}^{2}\right)$, and are higher than the median $\mathrm{Q}_{50}$ for August and September $(0.28$ and $0.27 \mathrm{ft}^{3} / \mathrm{s} / \mathrm{mi}^{2}$, respectively) for the LF group. The median streamflow requirement identified by the R2Cross 3-of-3 criteria method $\left(0.84 \mathrm{ft}^{3} / \mathrm{s} / \mathrm{mi}^{2}\right)$ exceeded median $\mathrm{Q}_{50}$ flows for the LF group during June, July, August, September, and October, and was more similar to median $\mathrm{Q}_{10}$ flows in July, August, and September $\left(0.89,0.81\right.$, and $0.78 \mathrm{ft}^{3} / \mathrm{s} / \mathrm{mi}^{2}$, respectively). The R2Cross 3-of-3 criteria method streamflow requirement $\left(0.84 \mathrm{ft}^{3} / \mathrm{s} / \mathrm{mi}^{2}\right)$ also exceeds the median $\mathrm{Q}_{25}$ for the LF group for July, August, and September, meaning that streamflows would be below the R2Cross 3-of-3 criteria streamflow requirement more than 75 percent of the time for these months during an average year. 
Table 17. Summer streamflow requirements and corresponding flow durations for the high-flow group and low-flow groups of index streamflow-gaging stations in southern New England.

[Methods: $\mathrm{Q}_{\mathrm{MA}}$, mean annual flow; RVA, Range of Variability Approach. $\mathrm{ft}^{3} / \mathrm{s} / \mathrm{mi}^{2}$, cubic foot per second per square mile; $\mathrm{mi}^{2}$, square mile]

\begin{tabular}{|c|c|c|c|}
\hline Method & Site(s) & $\begin{array}{c}\text { Discharge per } \\
\text { unit drainage } \\
\text { basin area } \\
\left(\mathrm{ft}^{3} / \mathrm{s} / \mathrm{mi}^{2}\right)\end{array}$ & $\begin{array}{c}\text { Annual flow } \\
\text { duration } \\
\text { (percent } \\
\text { exceedance) }\end{array}$ \\
\hline \multicolumn{4}{|c|}{ High-flow group } \\
\hline $\begin{array}{l}\text { RVA 75th percentile Highest percentile, } \\
\text { July-September }\end{array}$ & High-flow group (six sites) & 1.3 & 54 \\
\hline $\mathrm{R} 2$ Cross 3 -of-3 criteria & Wood River riffle site & .73 & 76 \\
\hline Tennant 30-percent $\mathrm{Q}_{\mathrm{MA}}$ & High-flow group (six sites) & 62 & 77 \\
\hline ABF Median of August mean & Branch River $\left(91.2 \mathrm{mi}^{2}\right)$ & .57 & 78 \\
\hline Canadian Atlantic Provinces 25-percent $\mathrm{Q}_{\mathrm{MA}}$ & High-flow group (six sites) & .52 & 82 \\
\hline Tennant 10-percent $\mathrm{Q}_{\mathrm{MA}}$ & High-flow group (six sites) & .21 & 97 \\
\hline \multicolumn{4}{|c|}{ Low-flow group } \\
\hline $\begin{array}{l}\text { RVA 75th percentile Highest percentile, } \\
\text { July-September }\end{array}$ & Low-flow group (17 sites) & 0.84 & 59 \\
\hline $\mathrm{R} 2$ Cross 3-of-3 criteria & Nine riffle sites & .84 & 60 \\
\hline Tennant 40-percent $\mathrm{Q}_{\mathrm{MA}}$ & Low-flow group (17 sites) & .77 & 61 \\
\hline Tennant 30-percent $\mathrm{Q}_{\mathrm{MA}}$ & Low-flow group (17 sites) & .58 & 69 \\
\hline Canadian Atlantic Provinces 25-percent $\mathrm{Q}_{\mathrm{MA}}$ & Low-flow group (17 sites) & .48 & 73 \\
\hline ABF Median of August mean & Four sites with drainage areas greater than $50 \mathrm{mi}^{2}$ & .45 & 75 \\
\hline
\end{tabular}

Comparisons of streamflow requirements to monthly $\mathrm{Q}_{50}$ discharges are useful to show how the streamflow requirements compare to streamflows for an average month or year. The magnitude of monthly flow durations can vary from year to year, however. The IQR of median monthly flow durations (table 6, fig. 7) provides a measure of the variability of median flows between years (between 1976-2000). For example, the August $\mathrm{Q}_{50}$ for the $\mathrm{HF}$ group had a median of $0.49 \mathrm{ft}^{3} / \mathrm{s} / \mathrm{mi}^{2}$ and an IQR that ranged between 0.30 and $0.87 \mathrm{ft}^{3} / \mathrm{s} / \mathrm{mi}^{2}$, whereas the August $\mathrm{Q}_{50}$ for the LF group had a median of $0.28 \mathrm{ft}^{3} / \mathrm{s} / \mathrm{mi}^{2}$ and an IQR that ranged between 0.16 and $0.47 \mathrm{ft}^{3} / \mathrm{s} / \mathrm{mi}^{2}$ (fig. 10). Comparison of streamflow requirements to the IQR of median $\mathrm{Q}_{50}$ discharges indicates whether the streamflow requirement falls within the 50-percent confidence interval for the $\mathrm{Q}_{50}$ discharge. Comparison of streamflow requirements to the 75 th and 25th percentile also allows evaluation of the streamflow requirement during wet and dry periods, respectively. For example, the median Wetted-Perimeter streamflow requirement for the LF group was $0.39 \mathrm{ft}^{3} / \mathrm{s} / \mathrm{mi}^{2}$. The 75th percentile of the median August $\mathrm{Q}_{25}\left(0.31 \mathrm{ft}^{3} / \mathrm{s} / \mathrm{mi}^{2}\right)$ (fig. 7) indicates that streamflows may be less than the Wetted-Perimeter streamflow requirement for part of the month, even during a wet period. The 25th percentile of the median August $\mathrm{Q}_{50}\left(0.16 \mathrm{ft}^{3} / \mathrm{s} / \mathrm{mi}^{2}\right)$ indicates that streamflows may be less than half of the WettedPerimeter streamflow requirement during a dry period, even for rivers with minimal flow alterations.

The streamflow requirements determined by the various standard-setting methods fell mostly within the range of flows identified as flow-management targets by the RVA for the summer months. The RVA flow-management targets, normalized by drainage area, ranged between 0.21 and 0.84 $\mathrm{ft}^{3} / \mathrm{s} / \mathrm{mi}^{2}$ (fig. 10A) for the LF group, and 0.37 and $1.27 \mathrm{ft}^{3} / \mathrm{s} / \mathrm{mi}^{2}$ for the HF group (fig. 10). The flow-management targets recommended by the RVA method are based on the IQR for 

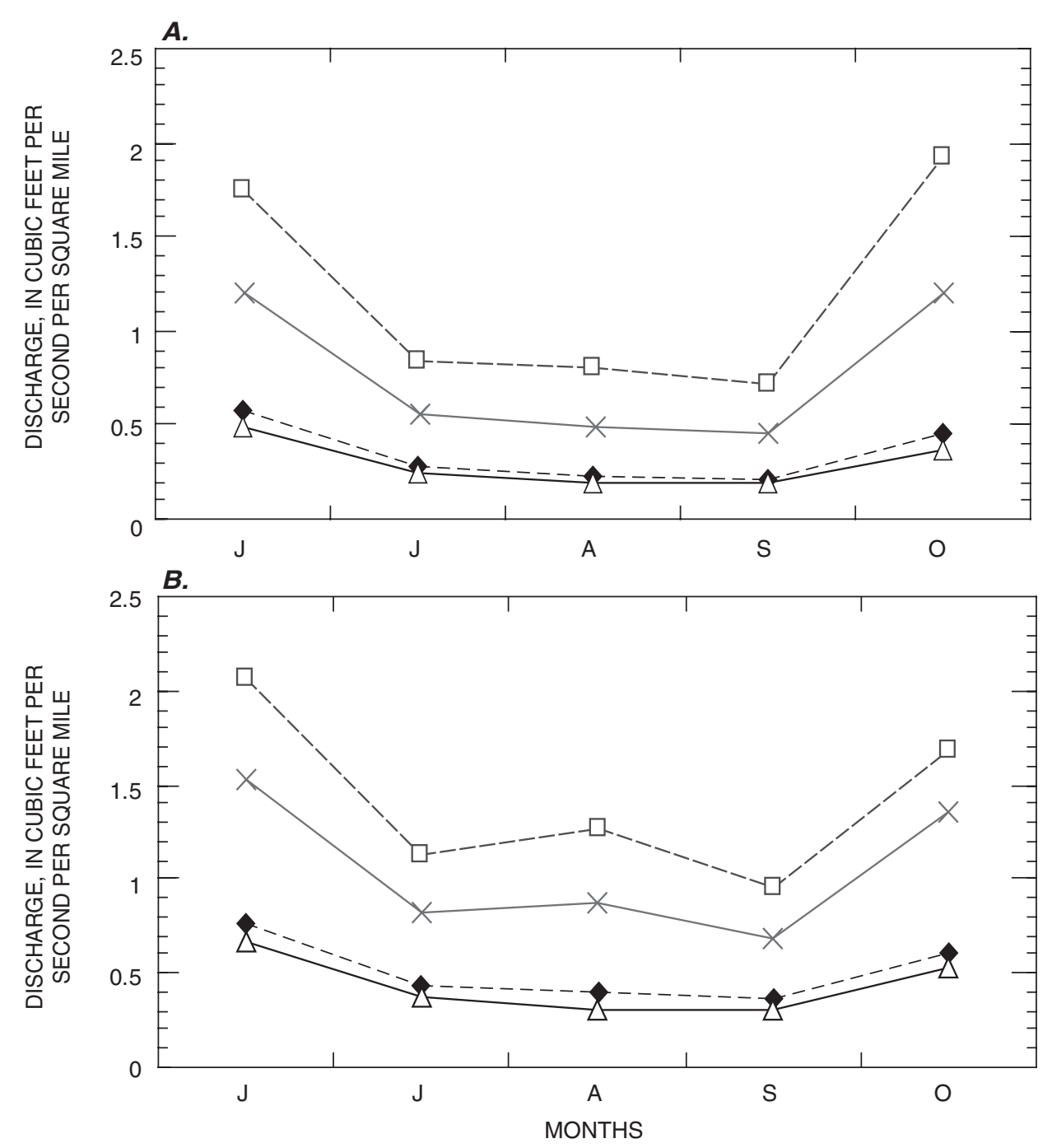

EXPLANATION

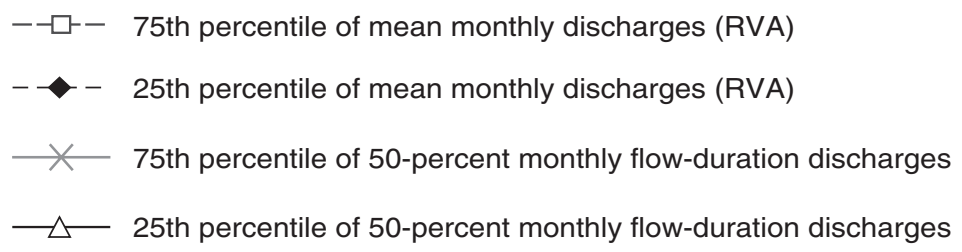

Figure 10. Comparison of Range of Variability Approach flow-management targets, normalized by drainage area, in southern New England, to the 25th and 75th percentiles of the 50-percent monthly flow duration for the: $A$, low monthly flow-duration group; and $B$, high monthly flowduration group.

mean monthly flows, and have a greater range than the IQR for median $\mathrm{Q}_{50}$ discharges. The lower (25th-percentile) range of the RVA flow-management targets and the 25th percentile of the $\mathrm{Q}_{50}$ are about the same values because they are mostly determined from base flows, which generally are stable flows. The upper (75th percentile) range of the RVA flow-management targets are higher than the 75 th percentile of the $\mathrm{Q}_{50}$ because the monthly mean discharge is biased upward by high streamflows from storms. Because storms are infrequent, the daily mean streamflows may exceed the mean monthly streamflow for only a few days or a week out of the month. 


\section{Suggestions for Further Study}

Application of the Wetted-Perimeter and R2Cross methods in this study to riffle habitats near 10 index streamflow-gaging stations in southern New England provides information about the streamflows needed to meet the criteria required by those methods and how often those flows occur. Application of a riffle-based approach in Massachusetts would require more information on the variability of streamflow requirements that may result when riffle-based methods are applied to multiple riffles with different physical characteristics and locations within a river basin. More information would also be needed about the degree to which stream channels adjust to altered flows and the effects of these channel adjustments on streamflow requirements.

Investigation of median $\mathrm{Q}_{50}$ discharges at 23 index stations indicated that median $\mathrm{Q}_{50}$ discharges could be characterized by grouping stations by geographic location during the high-flow period of the year and by base-flow index and percentage of sand and gravel in the drainage area during the low-flow period of the year. The flow characteristics of these rivers are most likely distributed along a continuum between the different end members of the groups; however, further investigation would be necessary to quantify relations between basin characteristics and flows. This analysis would be more robust if more stations were included in the analysis, and if saturated thickness and transmissivity data were available for aquifers. Although southern New England has few additional index stations that have long-term records, further investigation of flow statistics at streamflow-gaging stations with shorter periods of record could be used to refine these groupings.

Few index stations were available in eastern Massachusetts. Consequently, basins whose contributing areas have low gradients and high percentages of sand and gravel are underrepresented in this study. An example of relatively unaltered streamflows representative of a basin with these characteristics can be obtained from the streamflows simulated for the Ipswich River under no-withdrawal and 1991 land-use conditions (Zarriello and Ries, 2000). New index stations would be particularly useful near the Interstate 495 corridor.

Streamflow requirements determined by riffle-based approaches, such as the Wetted-Perimeter and R2Cross methods, are based on the assumption that maintaining riffle habitat during summer provides conditions adequate to sustain fish communities in nearby habitats. Additional investigation would be needed to understand the relation between streamflow and fish-habitat needs in riffles and adjacent habitats, and to understand how fish-habitat needs vary throughout the year.

Analysis of the fish samples collected for this study in the Indian Head and Old Swamp Rivers and in Priest Brook suggests that the fish communities in these rivers may be impaired when compared to a natural condition. Factors other than flow alterations that can strongly affect fish-community composition include degraded water quality, habitat alterations, and reductions in fish passage and river connectivity created by impoundments. Additional analysis in the Indian Head and Old Swamp Rivers and Priest Brook would be necessary to assess the source of impairment in these rivers. More information about the relation between flow alterations and fish-community composition would be needed to develop a flow metric for an Index of Biotic Integrity for Massachusetts. A comparison of fish communities and flow statistics from a set of rivers affected primarily by different amounts of flow alteration could potentially indicate the degree to which natural flow regimes can be altered while still sustaining the structure and composition of riverine fish communities. Long-term monitoring of fish populations across southern New England would be needed to further refine the development of target fish communities for rivers in different regions and with differing flow characteristics.

\section{Summary and Conclusions}

Streamflow statistics and methods for determining streamflow requirements for habitat protection were investigated at index streamflow-gaging stations in southern New England by the U.S. Geological Survey, in cooperation with the Massachusetts Department of Conservation and Recreation, from October 2000 to October 2002. Monthly flow durations were determined for a 25 -year period from 19762000 from streamflow records for 23 index stations. Analysis indicated that the median $\mathrm{Q}_{50}$ discharges for the index stations, normalized by drainage area, could be characterized once the rivers were grouped by geographic region for the period from November to May, and by a base-flow index and the percentage of sand and gravel in the drainage area for the period from June to October. Rivers were combined into four regional groups roughly paralleling the coast. Median $\mathrm{Q}_{50}$ discharges within the geographic regions varied primarily with the magnitude of flow during January and February, and in the timing and magnitude of spring runoff. Rivers were combined into two groups for the low-flow period between June and October. Rivers with high median $\mathrm{Q}_{50}$ discharges (the HF group) generally had a baseflow index of greater than 0.12 , and drainage areas with more than 20 percent sand and gravel. Rivers with low median $\mathrm{Q}_{50}$ discharges (the LF group) generally had a base-flow index of less than 0.12 , and drainage areas with less than 20 percent sand and gravel. Median $\mathrm{Q}_{50}$ discharges in July, August, and September, normalized by drainage area, were $0.57,0.49$, and $0.46 \mathrm{ft}^{3} / \mathrm{s} / \mathrm{mi}^{2}$, respectively, for the index stations in the HF group, and $0.34,0.28$, and $0.27 \mathrm{ft}^{3} / \mathrm{s} / \mathrm{mi}^{2}$, respectively, for the index stations in the LF group.

Fish communities in rivers with index stations in Massachusetts were sampled to compare the proportion of fluvial fish with those expected for rivers with natural flow conditions. Most of the rivers had fish populations dominated by fluvial species. Comparison to a target fish community representing the condition of a fish community in the mainstem reaches of relatively natural rivers in southern New England 
indicated that fish communities for three of the rivers may be impaired when compared to a natural condition. These alterations, however, may be caused by factors other than flow. The high percentage of fluvial species in the fish communities at most of the index stations indicates that these sites have nondegraded habitats and minimally altered flow conditions. The relatively unaltered flow condition at these sites was assumed to be one factor that has contributed to this condition. These findings support the use of these stations as index stations.

A diagnostic method and four standard-setting methods were used for determination of streamflow requirements for habitat protection. Three of these methods, the Range of Variability Approach, Tennant, and New England AquaticBase-Flow methods, are based on hydrologic records, and were used to calculate streamflow requirements for all 23 index stations. The remaining two methods, the Wetted-Perimeter and R2Cross methods, are field-based hydraulic-rating methods. These methods used HEC-RAS, a one-dimensional watersurface profile model, to simulate hydraulic parameters for riffle habitats near 10 of the index stations. Streamflow requirements determined by these methods were evaluated by comparison to streamflow statistics from the index stations.

Flow-management targets were determined by the Range of Variability Approach for each month and for low-flow statistics. Flow-management targets, normalized by drainage area, for July, August and September, ranged between 0.21 and $0.84 \mathrm{ft}^{3} / \mathrm{s} / \mathrm{mi}^{2}$ for the LF group, and 0.37 and $1.27 \mathrm{ft}^{3} / \mathrm{s} / \mathrm{mi}^{2}$ for the HF group. Normalized median streamflow requirements for habitat protection during the low-flow season for the 23 index streamflow-gaging stations determined by the Tennant method were $0.81,0.61,0.41$, and $0.21 \mathrm{ft}^{3} / \mathrm{s} / \mathrm{mi}^{2}$ for the Tennant 40-, 30-, 20-, and 10-percent $\mathrm{Q}_{\mathrm{MA}}$ methods, respectively. New England Aquatic-Base-Flow streamflow requirements for habitat protection during summer were $0.48 \mathrm{ft}^{3} / \mathrm{s} / \mathrm{mi}^{2}$, as determined from the medians of monthly mean flows for August for 5 streamflow-gaging stations with drainage areas greater than $50 \mathrm{mi}^{2}$. The average median monthly mean streamflow for August for 6 stations in the HF group was $0.64 \mathrm{ft}^{3} / \mathrm{s} / \mathrm{mi}^{2}$, and the average median monthly mean streamflow for August for 17 stations in the LF group was $0.41 \mathrm{ft}^{3} / \mathrm{s} / \mathrm{mi}^{2}$. Wetted-Perimeter and R2Cross streamflow requirements for habitat protection were determined for riffle habitats for nine streamflow-gaging stations in the LF group. Normalized streamflow requirements ranged between 0.13 and $0.58 \mathrm{ft}^{3} / \mathrm{s} / \mathrm{mi}^{2}$, with a median value of $0.39 \mathrm{ft}^{3} / \mathrm{s} / \mathrm{mi}^{2}$. Normalized streamflow requirements for the R2Cross 3-of-3 criteria method, normalized by drainage area, ranged between 0.39 and $2.1 \mathrm{ft}^{3} / \mathrm{s} / \mathrm{mi}^{2}$, with a median value of $0.84 \mathrm{ft}^{3} / \mathrm{s} / \mathrm{mi}^{2}$. Streamflow requirements for the R2Cross 2-of-3 criteria method, normalized by drainage area, ranged between 0.16 and $0.85 \mathrm{ft}^{3} / \mathrm{s} / \mathrm{mi}^{2}$, with a median value of $0.35 \mathrm{ft}^{3} / \mathrm{s} / \mathrm{mi}^{2}$.

Streamflow requirements for the LF group, which included 17 index streamflow-gaging stations, were $0.41 \mathrm{ft}^{3} / \mathrm{s} / \mathrm{mi}^{2}$ as determined by the Tennant $0.20 \mathrm{Q}_{\mathrm{MA}}$ method; $0.41 \mathrm{ft}^{3} / \mathrm{s} / \mathrm{mi}^{2}$ as determined by the ABF method; $0.39 \mathrm{ft}^{3} / \mathrm{s} / \mathrm{mi}^{2}$ as determined by the Wetted-Perimeter method; and $0.35 \mathrm{ft}^{3} / \mathrm{s} / \mathrm{mi}^{2}$ as determined by the R2Cross 2-of- 3 criteria method. These values were less than the median $\mathrm{Q}_{50}$ discharges from the index streamflow-gaging stations in the LF group for June $\left(0.70 \mathrm{ft}^{3} / \mathrm{s} / \mathrm{mi}^{2}\right)$ and October $\left(0.55 \mathrm{ft}^{3} / \mathrm{s} / \mathrm{mi}^{2}\right)$, and were greater than or equal to the median $\mathrm{Q}_{50}$ discharges for July $\left(0.35 \mathrm{ft}^{3} / \mathrm{s} / \mathrm{mi}^{2}\right)$, August $\left(0.28 \mathrm{ft}^{3} / \mathrm{s} / \mathrm{mi}^{2}\right)$, and September $\left(0.27 \mathrm{ft}^{3} / \mathrm{s} / \mathrm{mi}^{2}\right)$. For the LF group of index streamflow-gaging stations, the median $\mathrm{Q}_{50}$ discharges for July $\left(0.35 \mathrm{ft}^{3} / \mathrm{s} / \mathrm{mi}^{2}\right)$ and September $\left(0.27 \mathrm{ft}^{3} / \mathrm{s} / \mathrm{mi}^{2}\right)$ corresponded with average annual exceedance probabilities of 80 and 85 percent, respectively.

Streamflow variability within different months of a year and between years can be characterized by use of monthly flowduration curves. For example, the median $\mathrm{Q}_{50}$ discharge for August had an IQR of 0.30 to $0.87 \mathrm{ft}^{3} / \mathrm{s} / \mathrm{mi}^{2}$ for the HF group and 0.16 to $0.47 \mathrm{ft}^{3} / \mathrm{s} / \mathrm{mi}^{2}$ for the LF group. Comparison of streamflow requirements to the IQR of median $\mathrm{Q}_{50}$ discharges indicates whether a streamflow requirement falls within the 50 percent confidence interval for the $\mathrm{Q}_{50}$ discharge and also allows evaluation of streamflow requirements during wet and dry periods. Comparisons of streamflow requirements to different flow-duration discharges (such as $\mathrm{Q}_{25}, \mathrm{Q}_{50}$, and $\mathrm{Q}_{75}$ ) can indicate how the streamflow requirements from the various methods compare to streamflows within a month for an average year. The statistical summaries from the index stations and streamflow requirements determined by the five methods can be used by water-resources managers to guide the determination of streamflows for the protection of stream habitat.

\section{References Cited}

Aadland, L.P., 1993, Stream habitat types-Their fish assemblages and relationship to flow: North American Journal of Fisheries Management, v. 13, p 790-806.

Annear, T.C., and Conder, A.L., 1984, Relative bias of several fisheries instream flow methods: North American Journal of Fisheries Management, v. 4, p. 531-539.

Apse, D.D., 2000, Instream flow protection in New England -Status, critique, and new approaches to standard-setting: New Haven, CT, Masters thesis, Yale School of Forestry, $119 \mathrm{p}$.

Armstrong, D.S., and Parker, G.W., 2003, Assessment of habitat and streamflow requirements for habitat protection, Usquepaug-Queen River, Rhode Island, 1999-2000: U.S. Geological Survey Open-File Report 02-438, 69 p.

Armstrong, D.S., Parker, G.W., and Richards, T.A., 2001, Assessment of habitat, fish communities, and streamflow requirements for habitat protection, Ipswich River, Massachusetts, 1998-99: U.S. Geological Survey WaterResources Investigations Report 01-4161, 72 p.

Bain, M.B., Finn, J.T., and Booke, H.E., 1988, Streamflow regulation and fish community structure: Ecology, v. 69 p. 382-392. 
Bain, M.B., and Knight, J.G., 1996, Classifying stream habitat using fish community analyses, in Leclerc, Michel, Capra, Herve, Valentin, Sylvie, Boudreault, Andre, and Cote, Yvon, eds., Proceedings of the second IAHR Symposium on habitat hydraulics: Quebec, Canada, June Ecohydraulics 2000, Institut National de la Recherche Scientifique-Eau, Ste-Foy, p. B107-B117.

Bain, M.B., and Meixler, M.S., 2000, Defining a target fish community for planning and evaluating enhancement of the Quinebaug River in Massachusetts and Connecticut: Ithaca, NY, New York Cooperative Fish and Wildlife Research Unit, Cornell University, $20 \mathrm{p}$.

Bain, M.B., and Stevenson, N.J., eds., 1999, Aquatic habitat assessment-Common methods: Bethesda, MD, 2American Fisheries Society, 16 p.

Bain, M.B., and Travnichek, V.H., 1996, Assessing impacts and predicting restoration benefits of flow alterations in rivers developed for hydroelectric power production, in Leclerc, Michel, Capra, Herve, Valentin, Sylvie, Boudreault, Andre, and Cote, Yvon, eds., Proceedings of the second IAHR Symposium on habitat hydraulics: Quebec, Canada, June Ecohydraulics 2000, Institut National de la Recherche Scientifique-Eau, Ste-Foy, p. B543-B552.

Bauer, S.B., and Ralph, S.C., 1999, Aquatic habitat indicators and their application to water quality objectives within the clean water act: U.S. Environmental Protection Agency, EPA 910-R-99-014, 114 p.

Bent, G.C., 1995, Streamflow, ground-water recharge and discharge, and characteristics of surficial deposits in Buzzards Bay basin, southeastern Massachusetts: U.S. Geological Survey Water-Resources Investigations Report 95-4234, $56 \mathrm{p}$.

Bent, G.C., 1998, Streamflow, base flow, and ground-water recharge in the Housatonic River basin, western Massachusetts and parts of eastern New York and Northwestern Connecticut: U.S. Geological Survey WaterResources Investigations Report 98-4232, 68 p.

Beschta, R.L., and Platts, W. S., 1986, Morphological features of small streams-significance and function: Water Resources Bulletin, v.22: p. 369-379.

Brunner, G.W., 2001, HEC-RAS, River Analysis System User's Manual, Version 3.0, January 2001: Davis, CA, U.S. Army Corps of Engineers Hydrologic Engineering Center (HEC), CDP-68, variously paged.

Colorado Water Conservation Board, 2001, Memorandum to Colorado Water Conservation Board Members, May 11, 2001, accessed on November 30, 2001, at URL http://cwcb.state.co.us/agendas/May\%2001/ 14\%20-ISF\%20Quantification\%20Policy.pdf

De Lima, Virginia, 1991, Stream-aquifer relations and yield of stratified-drift aquifers in the Nashua River basin, Massachusetts: U.S. Geological Survey Water-Resources Investigations report 88-4147, $47 \mathrm{p}$.

Denny, C.S., 1982, Geomorphology of New England: U.S. Geological Survey Professional Paper 1208, 18 p.
Dunbar, M.J., Acreman, M.C., Gustard, A., Elliott, C.R.N., 1998, Overseas approaches to setting river flow objectives: Wallingford, U.K., Institute of Hydrology, Environmental Agency R\&D Technical Report W6B(96)4, 80 p.

Dunne, Thomas, and Leopold, L.B., 1978, Water in environmental planning: W.H. New York, Freeman and Company, $818 \mathrm{p}$.

Dupigny-Giroux, Lesley-Ann, 2003, A primer on weather and climate in Vermont: Burlington, VT, Office of the State Climatologist, accessed on September 29, 2003 at http://www.uvm.edu/ ldupigny/sc/climate_vermont.html

Environmental Systems Research Institute, Inc. (ESRI), 1994, ARC/INFO user guides, version 7: Redlands, CA, Environmental Systems Research Institute, Inc., 626 p.

Espegren, G.D., 1996, Development of instream flow recommendations in Colorado using R2CROSS: Denver, $\mathrm{CO}$, Water Conservation Board, $34 \mathrm{p}$.

Espegren, G.D., 1998, Evaluation of the standards and methods used for quantifying instream flows in Colorado: Denver, $\mathrm{CO}$, Water Conservation Board, 18 p.

Fennessey, N.M., 1996, Estimating the firm yield of a surface water reservoir supply system in Massachusetts-A guidance document: Boston, MA, Department of Environmental Protection, Office of Watershed Management, Water Management Program, variously paged.

Fennessey, N.M., and Vogel, R.M., 1990, Regional flowduration curves for ungauged sites in Massachusetts: Journal of Water Resources Planning and Management, v. 116, no. 4, p. 530-549.

Flanagan, S.M., Nielson, M.G., Robinson, K.W., and Coles, J.F., 1998, Water quality assessment of the New England coastal basins in Maine, Massachusetts, New Hampshire, and Rhode Island: Environmental settings and implications for water quality and aquatic biota: U.S. Geological Survey Water-Resources Investigations Report 98-4249, 56 p.

Flynn, R.H., 2003, Development of regression equations to estimate flow durations and low-flow-frequency statistics in New Hampshire streams: U.S. Geological Survey WaterResources Investigations Report 02-4298, 66 p.

Gadoury, R.A., and Wandle, S.W., 1986, Massachusetts surface-water resources, in Moody, D.W., Chase, E.B., and Aronson, D.A., eds., National Water Summary 1985Hydrologic events and surface water resources: U.S. Geological Survey Water-Supply Paper 2300, p. 271-276.

Gibson, G.R., Barbour, M.T., Stribling, J.B., Gerritsen, J., and Karr, J.R., 1996, Biological criteria-Technical guidance for streams and small rivers (revised edition): U.S. Environmental Protection Acency, EPA 822-B-96-001, $162 \mathrm{p}$.

Gippel, C. and Stewardson, M., 1996, Use of wetted perimeter in defining minimum environmental flows, in Leclerc, Michel, Capra, Herve, Valentin, Sylvie, Boudreault, Andre, and Cote, Yvon, eds., Proceedings of the second IAHR Symposium on habitat hydraulics: Quebec, Canada, June Ecohydraulics 2000, Institut National de la Recherche Scientifique-Eau, Ste-Foy, A:571-582. 
Gordon, Nancy, McMahon, T.A., and Finlayson, B.L., 1992, Stream hydrology - An introduction for ecologists: New York, John Wiley and Sons, 526 p.

Halliwell, D.B., Langdon, R.W., Daniels, R.A. Kurtenbach, J.P., and Jacobson, R.A., 1999, Classification of freshwater fish species of the Northeastern United States for use in the development of indices of biological integrity, with regional applications, in Simon, T.P., ed., Assessing the sustainability and biological intregrity of water resources using fish communities: Boca Raton, FL, CRC Press, p. 301-338.

Hammond, R.E., and Cotton, John, 1986, New Hampshire surface-water resources, in Moody, D.W., Chase, E.B., and Aronson, D.A., eds., National Water Summary 1985Hydrologic events and surface water resources: U.S. Geological Survey Water-Supply Paper 2300, p. 271-276.

Helsel, D.R., and Hirsch, R.M., 1992, Statistical methods in water resources: U.S. Geological Survey, Techniques of Water-Resources Investigations, book 4, chap. A3, available on-line at at http://water.usgs.gov/pubs/twri/twri4a3/

Hill, M.T., Platts, W.S., and Beschta, R.L., 1991, Ecological and geomorphicological concepts for instream and out-ofchannel flow requirements: Rivers, v. 2, p. 198-210.

Instream Flow Council, 2002, Instream flows for riverine resource stewardship: Instream Flow Council, 411 p.

Johnston, H.E., 1986, Rhode Island surface-water resources, in Moody, D.W., Chase, E.B., and Aronson, D.A., eds., National Water Summary 1985-Hydrologic events and surface water resources: U.S. Geological Survey WaterSupply Paper 2300, p. 271-276.

Kondolf , G.M., and Wilcock, P.R., 1996, The flushing flow problem-Defining and evaluating objectives: Water Reources Research, v. 32, no. 8, p. 2589-2599.

Lang, Vernon, 1999, Questions and answers on the New England flow policy: Concord, NH, U.S. Fish and Wildlife Service, $9 \mathrm{p}$.

Leathe, S.A., and Nelson, F.A., 1986, A literature evaluation of Montana's wetted perimeter inflection point method for deriving instream flow recommendations: Helena, MT, Department of Fish, Wildlife, and Parks, 70 p.

Leonard, P. M., and Orth, D. J., 1988, Use of habitat guilds to determine instream flow requirements, North American Journal of Fisheries Management, v. 8, p. 399-409.

Leopold, L.B., 1994, A view of the river: Cambridge, MA, Harvard University Press, 298 p.

Leopold, L.B., Wolman, M.G., and Miller, J.P., 1964, Fluvial processes in geomorphology: New York, Dover Publications, Inc., 522 p.

Lohr, S.C., 1993, Wetted stream channel, fish-food organisms and trout relative to the wetted perimeter inflection method: Bozeman, MT, Montana State University, Ph.D. dissertation, 246 p.
Lyford, F.P., and Cohen, A.J., 1988, Estimation of water available for recharge to sand and gravel aquifers in the glaciated northeastern United States, in Randall, A.D., and Johnson, A.I., eds, Regional aquifer systems of the United States-The northeast glacial aquifers: American Water Resources Association Monograph Series No. 11, p. 37-61.

Mackey, P.C, Barlow, P.M., and Ries, K.G., III, 1998, Relations between discharge and wetted perimeter and other hydraulicgeometry characteristics at selected streamflow-gaging stations in Massachusetts: U.S. Geological Survey WaterResources Investigations Report 98-4094, 44 p.

MassGIS, 2001, MassGIS datalayer descriptions and guide to user services: Massachusetts Executive Office of Environmental Affairs, Massachusetts Geographic Information System, p. 77.

Molnar, Peter, Burlando, Paolo, and Ruf, Wolfgang, 2002, Integrated catchment assessment of riverine landscape dynamics: Aquatic Sciences, v. 64, p. 129-140.

Nehring, R.B., 1979, Evaluation of instream flow methods and determination of water quantity needs for streams in the State of Colorado: Fort Collins, CO, Division of Wildlife, $144 \mathrm{p}$.

Nelson, F.A., 1984, Guidelines for using the wetted perimeter (WETP) computer program of the Montana Department of Fish, Wildlife, and Parks: Bozeman, MT, Montana Department of Fish, Wildlife, and Parks, variously paged.

New Hampshire Department of Safety, 2003, Northeast mean seasonal snowfall map, accessed July 21, 2003, at URL http://www.nhoem.state.nh.us/mitigation/fig\%204-6.htm

Olden, J.D., and Poff, N.L., 2003, Redundancy and the choice of hydrologic indices for characterizing streamflow regimes: River Research and Applications, v. 19, p. 101-121.

Parker, G.W., and Armstrong, D.S., 2001, Preliminary assessment of streamflow requirements for habitat protection for selected sites on the Assabet and Charles Rivers, Eastern Massachusetts; U.S. Geological Survey Open-File Report 02-340, $35 \mathrm{p}$.

Petts, Geoffrey, and Calow, Peter, 1996, River restoration: Oxford, Blackwell Science Ltd., 231 p.

Poff, N.L., Allen, J.D., Bain, M.B., Karr, J.R., Prestagaard, K.L., Richter, B.D., Sparks, R.E., and Stromberg, J.C., 1997, The natural flow regime-A paradigm for river conservation and restoration: Bioscience, v. 47, p. 769-784.

Postel, Sandra and Richter, Brian, 2003, Rivers for lifeManaging water for people and nature: Washington DC, Island Press, $253 \mathrm{p}$.

Randall, A.D., 1996, Mean annual runoff, precipitation, and evapotranspiration in the glaciated northeastern United States, 1951-80: U.S.Geological Survey Open-File Report 96-395, scale 1:1,000,000, 2 sheets (available only as digital files).

Randall, A.D., 2001, Hydrogeologic framework of stratified drift aquifers in the glaciated Northeastern United States: U.S. Geological Survey Professional Paper 1415-B, 179 p.

Richter, B.D., Baumgartner, J.V., Powell, J., and Braun, D.P., 1996, A method for assessing hydrologic alteration within ecosystems: Conservation Biology, v. 10, p. 1163-1174. 
Rhode Island Water Resources Board, 2003, Establishing a streamflow standard for Rhode Island: Microsoft PowerPoint Presentation accessed January 22, 2004 at URL http://www.wrb.state.ri.us/programs/wa/wapac/streamflow/ 031703presentationHO.pdf

Richter, B.D., Baumgartner, J.V., Wigington, Robert, and Braun, D.P., 1997, How much water does a river need?: Freshwater Biology, v. 37, p. 231-249.

Richter, B.D., Mathews, Ruth, Harrison, D.L., and Wigington, Robert, 2003, Ecologically sustainable water managementManaging river flows for ecological integrity: Ecological Applications, v. 13, no. 1, p. 206-224.

Ries, K.G., III, 1997, August median streamflows in Massachusetts: U.S. Geological Survey Water-Resources Investigations Report 97-4190, $24 \mathrm{p}$.

Ries, K.G., III, and Friesz, P.J., 2000, Methods for estimating low-flow statistics for Massachusetts streams; U.S. Geological Survey Water-Resources Investigation Report 00-4139, $81 \mathrm{p}$.

Ries, K.G., III, Steeves, P.A., and Freeman, Aleda, 2000, Obtaining streamflow statistics for Massachusetts streams on the World Wide Web: U.S. Geological Survey Fact Sheet 104-00, 4 p.

Searcy, J.K., 1959, Flow-duration curves, Manual of Hydrology-Part 2, Low flow techiques: U.S. Geologial Survey Water-Supply Paper 1542-A, 133 p.

Simon, T.P., 1999, Assessing the sustainability and biological integrity of water resources using fish communities: New York, CRC Press, $671 \mathrm{p}$.

Slack, J.R., and Landwehr, J.M., 1992, Hydro-Climatic Data Network (HCDN) - A U.S. Geological Survey streamflow data set for the United States for the study of climate variations, 1874-1988: U.S. Geological Survey Open-File Report 91-129, 193 p.

Smythe, C.M., 2001, Indicators of Hydrologic Alteration User's Manual: The Nature Conservancy, available on-line at http://www.smythescisoft.com/smythe.html

Stalnaker, C.B., 1990, Minimum flow is a myth, in Bain, M.B., ed., Ecology and assessment of warmwater streamsworkshop synopses: Washington DC,U.S. Fish and Wildlife Service, Biological Report 90(05) p. 31-33
Tennant, D.L., 1976, Instream flow regimens for fish, wildlife, recreation, and related resources, in Instream flow needs, Volume II: Boise, ID, Proceedings of the symposium and specialty conference on instream flow needs, May 3-6, American Fisheries Society, p. 359-373.

U.S. Fish and Wildlife Service, 1981, Interim regional policy for New England stream flow recommendations: Newton Corner, MA, U.S. Fish and Wildlife Service, 3 p.

Vogel, R.M., and Fennessey, N.M., 1994, Flow-duration curves-New interpretation and confidence intervals: Journal of Water-Resources Planning and Management, v. 120 , p. $485-504$.

Vogel, R.M., and Fennessey, N.M., 1995, Flow duration curves II-A review of applications in water resources planning: Water Resources Bulletin, v. 31, no. 6, p. 1029-1039.

Ward, J.V., and Stanford, J.A., 1983, The serial discontinuity concept of lotic ecosystems, in Bartel, S., and Fontaine, T., eds., Dynamics of Lotic Ecosystems: Ann Arbor, MI., Ann Arbor Scientific Publishers, p. 29-42

Weiss, L.A., and Cervione, M.A., 1986, Connecticut surfacewater resources, in Moody, D.W., Chase, E.B., and Aronson, D.A., eds., National Water Summary 1985-Hydrologic events and surface water resources: U.S. Geological Survey Water-Supply Paper 2300, p. 271-276.

Zarriello, P.J., 2002, Effects of water-management alternatives on streamflow in the Ipswich River basin, Massachusetts: U.S. Geological Survey Open-File Report 01-483, 30 p.

Zarriello, P.J., and Ries, K.G., III, 2000, A precipitation-runoff model for analysis of the effects of water withdrawals on streamflow, Ipswich River basin, Massachusetts: U.S. Geological Survey Water-Resources Investigations Report 00-4029, 99 p.

Zielinski, G.A., and Keim, B.D., 2003, New England Weather, New England Climate: Hanover, NH, University Press of New England, 276 p.

Zimmerman, M.J., Grady, S.J., Todd-Trench, E.C., Flanagan, S.M., and Nielsen, M.G, 1996, Water-quality assessment of the Connecticut, Housatonic, and Thames river basins study unit-Analysis of available data on nutrients, suspended sediments, and pesticides, 1972-92: U.S. Geological Survey Water-Resources Investigations Report 95-4203, 162 p. 


\section{Table 18}



Table 18. Flow statistics determined by the Indicators of Hydrologic Alteration Approach, normalized by drainage area, for index streamflow-gaging stations: Wood River, Little River, Squannacook River, Green River in Williamstown, Branch River, and South River, southern New England.

[Percentiles were determined by use of $i(n+1)$ formula where $i=$ order of the individual number, after ranking, and $n=$ total number of values in the sample. The annual discharges were determined on the basis of a Water Year (October-September). --, not applicable]

\begin{tabular}{|c|c|c|c|c|c|c|}
\hline \multirow{2}{*}{ Period or condition } & \multicolumn{6}{|c|}{ Percentile } \\
\hline & 10th & 25th & 50th & 75th & 90th & $(75-25) / 50$ \\
\hline \multicolumn{7}{|c|}{ WOOD RIVER (Southeast Geographic Region) } \\
\hline \multicolumn{7}{|c|}{ Magnitude of monthly mean discharge (cubic feet per second per square mile) } \\
\hline October & 0.38 & 0.57 & 0.87 & 1.64 & 2.43 & 1.23 \\
\hline January & 1.37 & 2.01 & 3.06 & 3.71 & 5.5 & .56 \\
\hline February & 1.61 & 2.4 & 3.3 & 4.11 & 4.39 & .52 \\
\hline March & 2.28 & 2.8 & 3.64 & 4.79 & 5.9 & .55 \\
\hline April & 2.29 & 2.49 & 3.74 & 4.35 & 6.25 & .50 \\
\hline May & 1.58 & 1.89 & 2.45 & 3.26 & 4.14 & .56 \\
\hline September & .28 & .49 & .61 & .90 & 1.26 & 67 \\
\hline \multicolumn{7}{|c|}{$\begin{array}{l}\text { Magnitude and duration of annual discharges } \\
\text { (cubic feet per second per square mile) }\end{array}$} \\
\hline 1-day minimum & .13 & .19 & .25 & .37 & .46 & .71 \\
\hline 3-day minimum & .14 & .20 & .26 & .39 & .48 & .75 \\
\hline 7-day minimum & .15 & .23 & .30 & .46 & .51 & .77 \\
\hline 30-day minimum & .21 & .32 & .42 & .56 & .70 & .58 \\
\hline 90-day minimum & .34 & .46 & .72 & .86 & 1.19 & .56 \\
\hline 1-day maximum & 7.21 & 8.41 & 10.8 & 16.3 & 21.9 & .73 \\
\hline \multicolumn{7}{|c|}{ Timing of annual discharge extremes (Julian day) } \\
\hline Date of minimum 1-day discharge & 210.2 & 228.5 & 253 & 272 & 283.8 & .1 \\
\hline Date of maximum 1-day discharge & 351.8 & 25.5 & 71 & 110.5 & 141.4 & .2 \\
\hline \multicolumn{7}{|c|}{ Frequency and duration of high and low pulses } \\
\hline $\begin{array}{l}\text { Times that daily discharge is less than } \\
\text { the } 25 \text { th percentile of daily } \\
\text { discharge (count) }\end{array}$ & 4.6 & 5 & 8 & 9 & 11.4 & .5 \\
\hline $\begin{array}{l}\text { Days that daily discharge is less than } \\
\text { the } 25 \text { th percentile }\end{array}$ & 5.8 & 7.2 & 10.6 & 14.2 & 22.7 & .7 \\
\hline $\begin{array}{l}\text { Times that daily discharge is greater } \\
\text { than the } 75 \text { th percentile of daily } \\
\text { discharge (count) }\end{array}$ & 3.6 & 6.5 & 10 & 13 & 16.8 & 6 \\
\hline $\begin{array}{l}\text { Days that daily discharge is greater } \\
\text { than the } 75 \text { th percentile }\end{array}$ & 3.4 & 5.6 & 9.8 & 13.5 & 17.8 & .8 \\
\hline
\end{tabular}


Table 18. Flow statistics determined by the Indicators of Hydrologic Alteration Approach, normalized by drainage area, for index streamflow-gaging stations: Wood River, Little River, Squannacook River, Green River in Williamstown, Branch River, and South River, southern New England.—Continued

[Percentiles were determined by use of $i(n+1)$ formula where $i=$ order of the individual number, after ranking, and $n=$ total number of values in the sample. The annual discharges were determined on the basis of a Water Year (October-September). --, not applicable]

\begin{tabular}{|c|c|c|c|c|c|c|}
\hline \multirow{2}{*}{ Period or condition } & \multicolumn{6}{|c|}{ Percentile } \\
\hline & 10th & 25th & 50th & 75th & 90th & $(75-25) / 50$ \\
\hline \multicolumn{7}{|c|}{ WO0D RIVER (Southeast Geographic Region)_CContinued } \\
\hline \multicolumn{7}{|c|}{ Rate and frequency of hydrograph changes } \\
\hline $\begin{array}{l}\text { Mean of all positive differences } \\
\text { between consecutive daily } \\
\text { discharges (rise rate) }\end{array}$ & 0.36 & 0.51 & 0.60 & 0.93 & 1.10 & 0.70 \\
\hline $\begin{array}{l}\text { Mean of all negative differences } \\
\text { between consecutive daily } \\
\text { discharges (fall rate) }\end{array}$ & -.39 & -.33 & -.22 & -.20 & -.14 & -.58 \\
\hline Number of reversals & 82.2 & 88 & 97 & 102 & 106.4 & .1 \\
\hline
\end{tabular}

\section{LITTLE RIVER (South Central Geographic Region)}

Magnitude of monthly mean discharge (cubic feet per second per square mile)

\begin{tabular}{|c|c|c|c|c|c|c|}
\hline October & 0.41 & 0.54 & 0.87 & 1.12 & 2.87 & 0.66 \\
\hline November & .66 & .90 & 1.81 & 2.49 & 3.43 & .88 \\
\hline December & .92 & 1.33 & 1.86 & 3.53 & 4.63 & 1.18 \\
\hline January & .92 & 1.42 & 2.75 & 3.57 & 5.79 & .78 \\
\hline February & 1.42 & 1.88 & 2.66 & 3.39 & 4.01 & .57 \\
\hline March & 1.95 & 2.65 & 3.15 & 4.63 & 5.3 & .63 \\
\hline April & 1.65 & 2.29 & 2.98 & 3.83 & 5.7 & .52 \\
\hline May & 1.21 & 1.53 & 2 & 2.67 & 3.39 & .57 \\
\hline June & .59 & .63 & .95 & 1.46 & 4.21 & .86 \\
\hline July & .30 & .37 & .51 & .84 & 1.43 & .91 \\
\hline August & .22 & .31 & .47 & .84 & 1.08 & 1.13 \\
\hline September & .21 & .30 & .42 & .75 & 1.01 & 1.06 \\
\hline \multicolumn{7}{|c|}{$\begin{array}{l}\text { Magnitude and duration of annual discharges } \\
\text { (cubic feet per second per square mile) }\end{array}$} \\
\hline 1-day minimum & .13 & .14 & .20 & .24 & .27 & .53 \\
\hline 3-day minimum & .14 & .15 & .20 & .25 & .28 & .54 \\
\hline 7-day minimum & .14 & .15 & .23 & .26 & .30 & .48 \\
\hline 30-day minimum & .16 & .19 & .31 & .36 & .51 & .55 \\
\hline 90-day minimum & .26 & .3 & .49 & .58 & .79 & .57 \\
\hline 1-day maximum & 11 & 16.4 & 21.8 & 29.1 & 45.8 & .58 \\
\hline 3-day maximum & 7.03 & 10.7 & 15.6 & 19 & 25.8 & .53 \\
\hline 7-day maximum & 4.52 & 7.02 & 9.45 & 13.7 & 17.5 & .71 \\
\hline 30-day maximum & 3.23 & 4.05 & 5.66 & 6.44 & 7.53 & 42 \\
\hline 90- day maximum & 2.55 & 2.98 & 3.82 & 4.31 & 5.15 & 5 \\
\hline Zero discharge days & 0 & 0 & 0 & 0 & 0 & 0 \\
\hline 7-day minimum/mean annual & .07 & .09 & .11 & .14 & .17 & \\
\hline
\end{tabular}

Timing of annual discharge extremes (Julian day)

Date of minimum 1-day discharge

Date of maximum 1-day discharge

203.6

294.6
227.5

27
253

82
268

99.5
285.6

159.6

0.66

.88

1.18

.78

.57

.63

.52

.57

.86

.91

.13

1.06

.53

.54

.48

.55

.57

.58

.53

.71

.42

.35

.49 49 
Table 18. Flow statistics determined by the Indicators of Hydrologic Alteration Approach, normalized by drainage area, for index streamflow-gaging stations: Wood River, Little River, Squannacook River, Green River in Williamstown, Branch River, and South River, southern New England.—Continued

[Percentiles were determined by use of $i(n+1)$ formula where $i=$ order of the individual number, after ranking, and $n=$ total number of values in the sample. The annual discharges were determined on the basis of a Water Year (October-September). --, not applicable]

\begin{tabular}{|c|c|c|c|c|c|c|}
\hline \multirow{2}{*}{ Period or condition } & \multicolumn{6}{|c|}{ Percentile } \\
\hline & 10th & 25th & 50th & 75th & 90th & $(75-25) / 50$ \\
\hline \multicolumn{7}{|c|}{ LITTLE RIVER (South Central Geographic Region)_Continued } \\
\hline \multicolumn{7}{|c|}{ Frequency and duration of high and low pulses } \\
\hline $\begin{array}{l}\text { Times that daily discharge is less than } \\
\text { the } 25 \text { th percentile of daily } \\
\text { discharge (count) }\end{array}$ & 5.6 & 7 & 8 & 10.5 & 12.8 & 0.4 \\
\hline $\begin{array}{l}\text { Days that daily discharge is less than } \\
\text { the } 25 \text { th percentile }\end{array}$ & 6.3 & 7 & 8.3 & 13.4 & 17.5 & .8 \\
\hline $\begin{array}{l}\text { Times that daily discharge is greater } \\
\text { than the 75th percentile of daily } \\
\text { discharge (count) }\end{array}$ & 8 & 12 & 17 & 19 & 20.4 & .4 \\
\hline $\begin{array}{l}\text { Days that daily discharge is greater } \\
\text { than the } 75 \text { th percentile }\end{array}$ & 3.2 & 4.4 & 5.9 & 6.7 & 9.9 & .4 \\
\hline $\begin{array}{l}\text { Mean of all negative differences } \\
\text { between consecutive daily } \\
\text { discharges (fall rate) }\end{array}$ & -.72 & -.64 & -.49 & -.35 & -.30 & -.58 \\
\hline Number of reversals & 97.2 & 98 & 109 & 111 & 121 & .1 \\
\hline
\end{tabular}

\section{SQUANNACOOK RIVER (North Central Geographic Region)}

Magnitude of monthly mean discharge (cubic feet per second per square mile)

\begin{tabular}{|c|c|c|c|c|c|c|}
\hline October & 0.31 & 0.4 & 0.63 & 1.56 & 2.46 & 1.84 \\
\hline November & .48 & .82 & 1.71 & 2.36 & 3.54 & .90 \\
\hline December & .62 & 1.02 & 1.34 & 2.88 & 3.96 & 1.38 \\
\hline January & .59 & 1.08 & 2.07 & 2.84 & 3.83 & .85 \\
\hline February & .94 & 1.36 & 1.94 & 3.14 & 3.9 & .91 \\
\hline March & 2.07 & 2.96 & 3.57 & 4.32 & 6.55 & .38 \\
\hline April & 1.52 & 2.3 & 3.87 & 5.25 & 6.44 & .76 \\
\hline May & .94 & 1.5 & 2.28 & 2.83 & 3.76 & .58 \\
\hline June & .42 & .61 & .96 & 2.12 & 4.05 & 1.57 \\
\hline July & .23 & .39 & .49 & .94 & 1.2 & 1.14 \\
\hline August & .20 & .28 & .42 & .78 & 1.25 & 1.17 \\
\hline September & .20 & .24 & .42 & .60 & .83 & .86 \\
\hline
\end{tabular}


Table 18. Flow statistics determined by the Indicators of Hydrologic Alteration Approach, normalized by drainage area, for index streamflow-gaging stations: Wood River, Little River, Squannacook River, Green River in Williamstown, Branch River, and South River, southern New England.—Continued

[Percentiles were determined by use of $i(n+1)$ formula where $i=$ order of the individual number, after ranking, and $n=$ total number of values in the sample. The annual discharges were determined on the basis of a Water Year (October-September). --, not applicable]

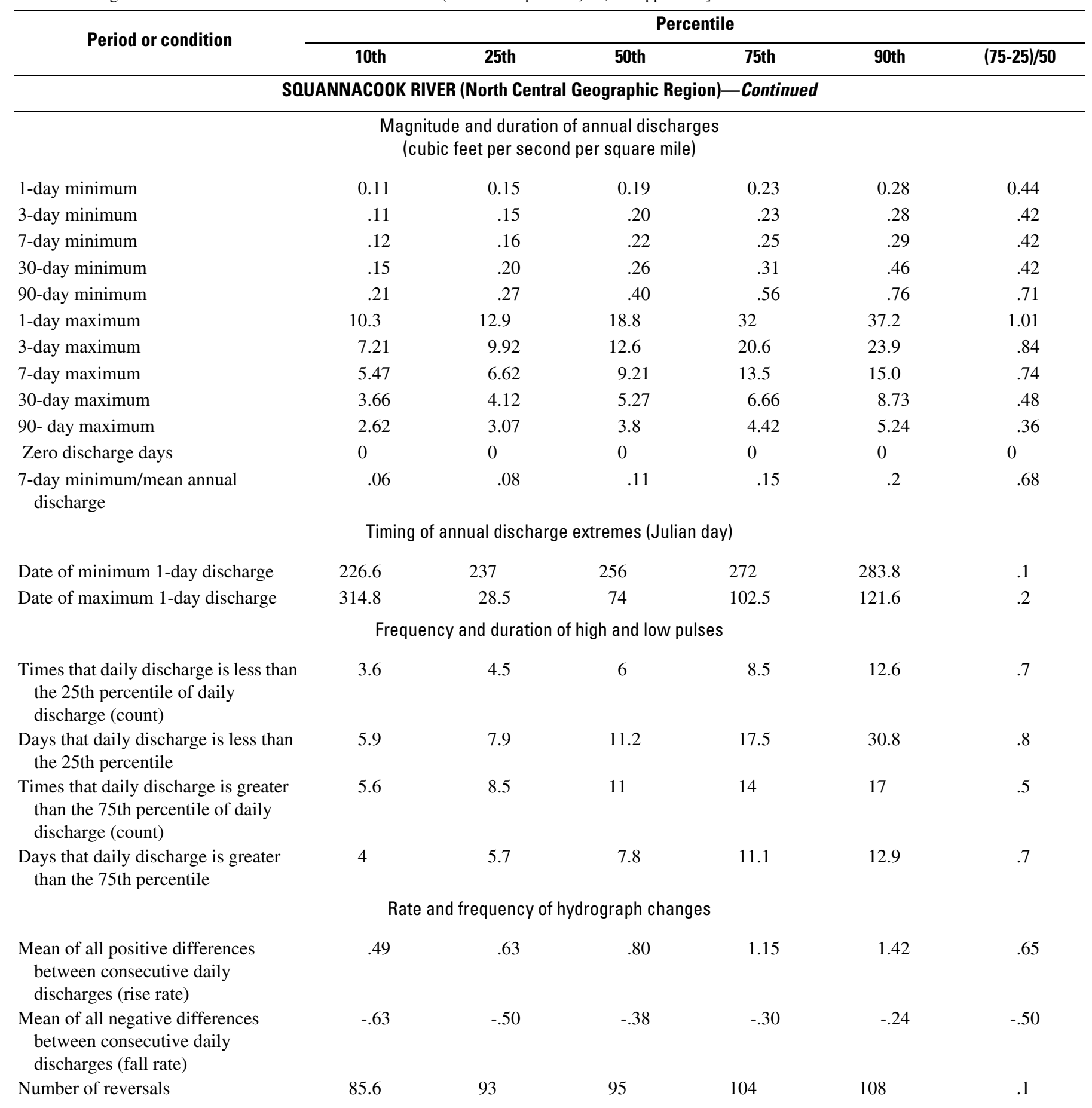


Table 18. Flow statistics determined by the Indicators of Hydrologic Alteration Approach, normalized by drainage area, for index streamflow-gaging stations: Wood River, Little River, Squannacook River, Green River in Williamstown, Branch River, and South River, southern New England.—Continued

[Percentiles were determined by use of $i(n+1)$ formula where $i=$ order of the individual number, after ranking, and $n=$ total number of values in the sample. The annual discharges were determined on the basis of a Water Year (October-September). --, not applicable]

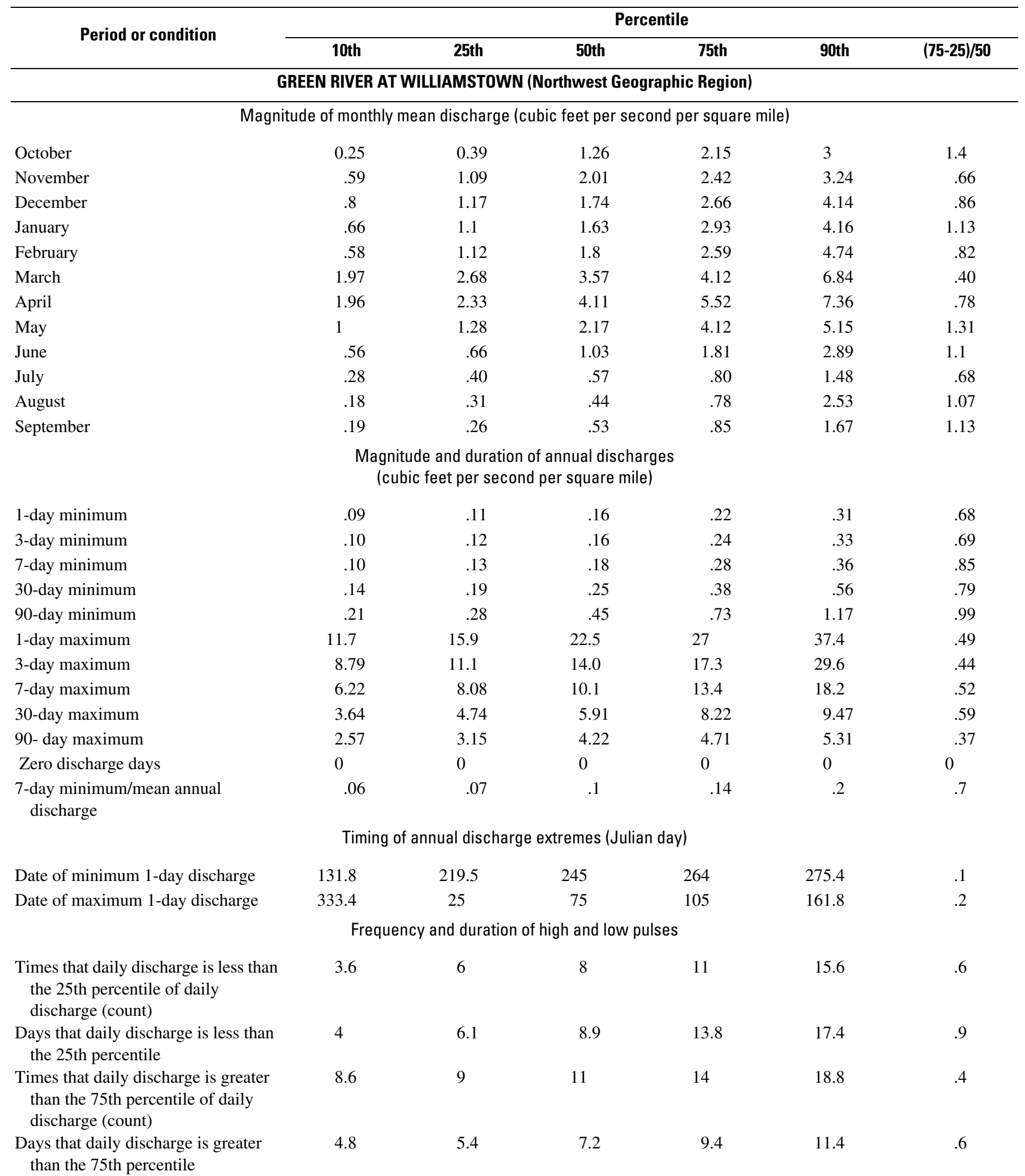


Table 18. Flow statistics determined by the Indicators of Hydrologic Alteration Approach, normalized by drainage area, for index streamflow-gaging stations: Wood River, Little River, Squannacook River, Green River in Williamstown, Branch River, and South River, southern New England.—Continued

[Percentiles were determined by use of $i(n+1)$ formula where $i=$ order of the individual number, after ranking, and $n=$ total number of values in the sample. The annual discharges were determined on the basis of a Water Year (October-September). --, not applicable]

\begin{tabular}{|c|c|c|c|c|c|c|}
\hline \multirow{2}{*}{ Period or condition } & \multicolumn{6}{|c|}{ Percentile } \\
\hline & 10th & 25th & 50th & 75th & 90th & $(75-25) / 50$ \\
\hline \multicolumn{7}{|c|}{ GREEN RIVER AT WILLIAMSTOWN (Northwest Geographic Region)_Continued } \\
\hline \multicolumn{7}{|c|}{ Rate and frequency of hydrograph changes } \\
\hline $\begin{array}{l}\text { Mean of all positive differences } \\
\text { between consecutive daily } \\
\text { discharges (rise rate) }\end{array}$ & 0.64 & 0.86 & 0.97 & 1.32 & 1.68 & 0.48 \\
\hline $\begin{array}{l}\text { Mean of all negative differences } \\
\text { between consecutive daily } \\
\text { discharges (fall rate) }\end{array}$ & -.58 & -.54 & -.40 & -.31 & -.23 & -.55 \\
\hline Number of reversals & 100.6 & 105.5 & 110 & 113.5 & 126.4 & .1 \\
\hline
\end{tabular}

Magnitude of monthly mean discharge (cubic feet per second per square mile)

\begin{tabular}{|c|c|c|c|c|c|c|}
\hline October & 0.64 & 0.76 & 0.94 & 1.45 & 3.66 & 0.74 \\
\hline November & .85 & 1.2 & 1.71 & 2.48 & 3.55 & .75 \\
\hline December & .87 & 1.2 & 1.78 & 3.55 & 5.05 & 1.32 \\
\hline January & 1.05 & 1.42 & 2.77 & 3.54 & 5.39 & .77 \\
\hline February & 1.53 & 1.91 & 2.65 & 3.7 & 4.17 & .67 \\
\hline March & 1.97 & 2.56 & 3.37 & 4.39 & 6.36 & .54 \\
\hline April & 1.4 & 2.04 & 3.35 & 4.37 & 7.06 & .69 \\
\hline May & 1.33 & 1.39 & 2.02 & 2.98 & 3.52 & .79 \\
\hline June & .52 & .58 & .93 & 1.98 & 4.12 & 1.51 \\
\hline July & .28 & .37 & .51 & .94 & 1.4 & 1.14 \\
\hline August & .25 & .29 & .57 & 1.03 & 1.72 & 1.3 \\
\hline September & .24 & .37 & .50 & .80 & 1.27 & .85 \\
\hline \multicolumn{7}{|c|}{$\begin{array}{l}\text { Magnitude and duration of annual discharges } \\
\text { (cubic feet per second per square mile) }\end{array}$} \\
\hline 1-day minimum & .12 & .16 & .20 & .25 & .30 & .44 \\
\hline 3-day minimum & .12 & .16 & .21 & .27 & .31 & .50 \\
\hline 7-day minimum & .13 & .17 & .23 & .29 & .35 & .52 \\
\hline 30-day minimum & .16 & .24 & .28 & .41 & .51 & .62 \\
\hline 90-day minimum & .26 & .38 & .52 & .65 & .98 & .51 \\
\hline 1-day maximum & 8.65 & 12.9 & 19 & 23.8 & 36.7 & .57 \\
\hline 3-day maximum & 6.84 & 10.8 & 12.7 & 17.3 & 28.9 & .51 \\
\hline 7-day maximum & 4.84 & 7.27 & 9.46 & 12.6 & 20.4 & .57 \\
\hline 30-day maximum & 3.35 & 4.07 & 5.99 & 7.18 & 8.37 & .52 \\
\hline 90- day maximum & 2.61 & 3.05 & 4.04 & 4.53 & 5.41 & .36 \\
\hline Zero discharge days & 0 & 0 & 0 & 0 & 0 & 0 \\
\hline 7-day minimum/mean annual & .06 & .08 & .12 & .15 & .18 & .51 \\
\hline
\end{tabular}

Timing of annual discharge extremes (Julian day)

Date of minimum 1-day discharge

Date of maximum 1-day discharge
203

308.2
220.5

26
248

71
265.5

96.5
275.4

143
0.74

.75

.32

.77

.67

.54

.69

.79

1.51

1.14

1.3

85

\section{4}

50

62 51

$$
51
$$


Table 18. Flow statistics determined by the Indicators of Hydrologic Alteration Approach, normalized by drainage area, for index streamflow-gaging stations: Wood River, Little River, Squannacook River, Green River in Williamstown, Branch River, and South River, southern New England.—Continued

[Percentiles were determined by use of $i(n+1)$ formula where $i=$ order of the individual number, after ranking, and $n=$ total number of values in the sample. The annual discharges were determined on the basis of a Water Year (October-September). --, not applicable]

\begin{tabular}{|c|c|c|c|c|c|c|}
\hline \multirow{2}{*}{ Period or condition } & \multicolumn{6}{|c|}{ Percentile } \\
\hline & 10th & 25th & 50th & 75th & 90th & $(75-25) / 50$ \\
\hline \multicolumn{7}{|c|}{ BRANCH RIVER (High Flow Group)—Continued } \\
\hline \multicolumn{7}{|c|}{ Frequency and duration of high and low pulses } \\
\hline $\begin{array}{l}\text { Times that daily discharge is less than } \\
\text { the } 25 \text { th percentile of daily } \\
\text { discharge (count) }\end{array}$ & 4.6 & 5 & 7 & 8.5 & 11.4 & 0.5 \\
\hline $\begin{array}{l}\text { Days that daily discharge is less than } \\
\text { the } 25 \text { th percentile }\end{array}$ & 5.4 & 8.4 & 14 & 18.4 & 23.8 & .7 \\
\hline $\begin{array}{l}\text { Times that daily discharge is greater } \\
\text { than the 75th percentile of daily } \\
\text { discharge (count) }\end{array}$ & 7.6 & 9 & 11 & 16 & 17 & .6 \\
\hline $\begin{array}{l}\text { Days that daily discharge is greater } \\
\text { than the } 75 \text { th percentile }\end{array}$ & 3.4 & 5.1 & 7.3 & 10 & 12 & .7 \\
\hline $\begin{array}{l}\text { Mean of all negative differences } \\
\text { between consecutive daily } \\
\text { discharges (fall rate) }\end{array}$ & -.54 & -.48 & -.36 & -.28 & -.20 & -.56 \\
\hline Number of reversals & 93 & 98.5 & 105 & 108 & 113 & .1 \\
\hline
\end{tabular}

SOUTH RIVER (Low Flow Group)

Magnitude of monthly mean discharge (cubic feet per second per square mile)

\begin{tabular}{|c|c|c|c|c|c|c|}
\hline October & 0.34 & 0.46 & 0.85 & 2.33 & 3.31 & 2.2 \\
\hline November & .49 & .73 & 2.14 & 3.15 & 4.05 & 1.13 \\
\hline December & .61 & .92 & 1.81 & 2.9 & 4 & 1.09 \\
\hline January & .63 & 1.22 & 1.59 & 3.15 & 4.1 & 1.21 \\
\hline February & .68 & 1.16 & 1.87 & 2.67 & 5.06 & .81 \\
\hline March & 2.06 & 3.09 & 3.66 & 5.7 & 7.24 & .71 \\
\hline April & 1.61 & 3.08 & 4.41 & 6.19 & 9.48 & .71 \\
\hline May & 1.18 & 1.6 & 2.81 & 3.81 & 5.22 & .79 \\
\hline June & .58 & .67 & 1.07 & 2.3 & 4.82 & 1.53 \\
\hline July & .30 & .42 & .52 & .97 & 2.29 & 1.06 \\
\hline August & .20 & .34 & .50 & 1.04 & 1.66 & 1.42 \\
\hline September & .21 & .27 & .55 & 1.15 & 1.48 & 1.61 \\
\hline
\end{tabular}


Table 18. Flow statistics determined by the Indicators of Hydrologic Alteration Approach, normalized by drainage area, for index streamflow-gaging stations: Wood River, Little River, Squannacook River, Green River in Williamstown, Branch River, and South River, southern New England.—Continued

[Percentiles were determined by use of $i(n+1)$ formula where $i=$ order of the individual number, after ranking, and $n=$ total number of values in the sample. The annual discharges were determined on the basis of a Water Year (October-September). --, not applicable]

\begin{tabular}{|c|c|c|c|c|c|c|}
\hline \multirow{2}{*}{ Period or condition } & \multicolumn{6}{|c|}{ Percentile } \\
\hline & 10th & 25th & 50th & 75th & 90th & $(75-25) / 50$ \\
\hline \multicolumn{7}{|c|}{ SOUTH RIVER (Low Flow Group) —Continued } \\
\hline \multicolumn{7}{|c|}{$\begin{array}{l}\text { Magnitude and duration of annual discharges } \\
\text { (cubic feet per second per square mile) }\end{array}$} \\
\hline 1-day minimum & 0.10 & 0.14 & 0.18 & 0.24 & 0.34 & 0.58 \\
\hline 7-day minimum & .11 & .16 & .20 & .30 & .36 & 69 \\
\hline 30-day minimum & .15 & .21 & .26 & .39 & .52 & .70 \\
\hline 90-day minimum & .26 & .34 & .44 & .69 & 1.13 & .81 \\
\hline 1-day maximum & 16.9 & 22 & 29.3 & 40 & 58.5 & 61 \\
\hline 3-day maximum & 9.77 & 13.1 & 17.6 & 23.9 & 34.3 & 61 \\
\hline Zero discharge days & 0 & 0 & 0 & 0 & 0 & 0 \\
\hline $\begin{array}{l}\text { 7-day minimum/mean annual } \\
\text { discharge }\end{array}$ & .06 & .07 & .09 & .14 & .18 & .77 \\
\hline \multicolumn{7}{|c|}{ Timing of annual discharge extremes (Julian day) } \\
\hline Date of minimum 1-day discharge & 210.4 & 219 & 251 & 268.5 & 276.2 & .1 \\
\hline Date of maximum 1-day discharge & 296.4 & 186 & 11 & 4 & 174 & .3 \\
\hline \multicolumn{7}{|c|}{ Frequency and duration of high and low pulses } \\
\hline $\begin{array}{l}\text { Times that daily discharge is less than } \\
\text { the } 25 \text { th percentile of daily } \\
\text { discharge (count) }\end{array}$ & 3.6 & 6 & 10 & 12.5 & 16.4 & .6 \\
\hline \multicolumn{7}{|c|}{ Rate and frequency of hydrograph changes } \\
\hline $\begin{array}{l}\text { Mean of all positive differences } \\
\text { between consecutive daily } \\
\text { discharges (rise rate) }\end{array}$ & .86 & 1.26 & 1.54 & 1.98 & 2.38 & .47 \\
\hline $\begin{array}{l}\text { Mean of all negative differences } \\
\text { between consecutive daily } \\
\text { discharges (fall rate) }\end{array}$ & -1.07 & -.77 & -.65 & -.53 & -.38 & -.38 \\
\hline Number of reversals & 84.6 & 101 & 107 & 114.5 & 119.4 & .1 \\
\hline
\end{tabular}




\section{Appendix 1: Annual Flow-Duration Curves for 10 Index Streamflow-Gaging Stations.}

Appendix 1 includes annual flow-duration curves for 10 index streamflow-gaging stations used for determination of Wetted-Perimeter and R2Cross streamflow requirements:

1-1. Annual flow-duration curve for Squannacook River near West Groton, MA (01096000), for water years 1976-2000 .....61

1-2. Annual flow-duration curve for Beaver Brook near Pelham, NH (010965852), for water years 1976-2000. . ...........61

1-3. Annual flow-duration curve for Old Swamp River near Weymouth, MA (01105600), for water years 1976-2000 . .......62

1-4. Annual flow-duration curve for Wood River near Arcadia, RI (01117800), for water years 1976-2000 ..............62

1-5. Annual flow-duration curve for Mount Hope near Warrenville, CT (01121000), for water years 1976-2000...........63

1-6. Annual flow-duration curve for Little River near Hanover, CT (01123000), for water years 1976-2000 . .............63

1-7. Annual flow-duration curve for South River near Conway, MA (01169900), for water years $1976-2000 \ldots \ldots \ldots \ldots \ldots .64$

1-8. Annual flow-duration curve for Green River near Colrain, MA (01170100), for water years 1976-2000 . . . . . . . . . . . 64

1-9. Annual flow-duration curve for Sevenmile River near Spencer, MA (01175670), for water years 1976-2000 . .........65

1-10. Annual flow-duration curve for Green River at Williamstown, MA (01333000), for water years 1976-2000 . . . . . . . . .65 



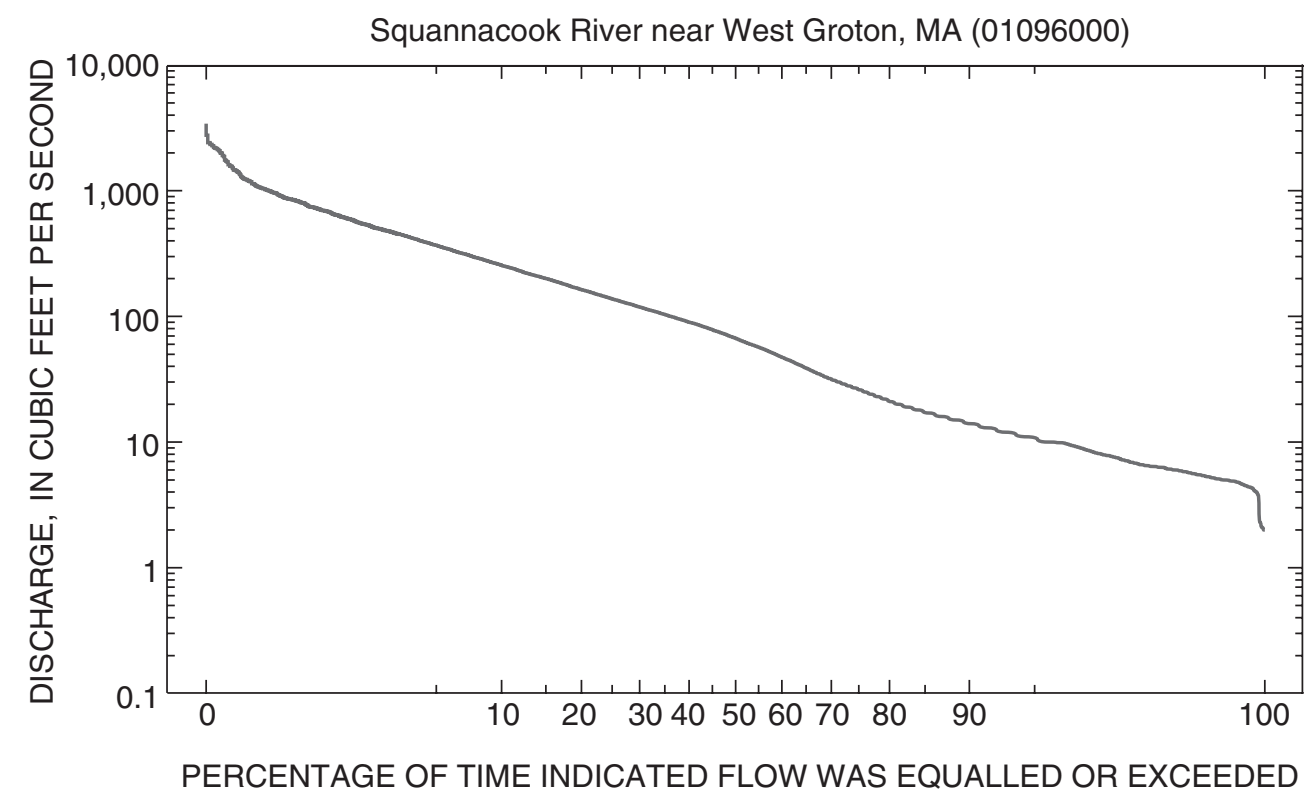

Figure 1-1. Annual flow-duration curve for Squannacook River near West Groton, MA (01096000), for water years 1976-2000.

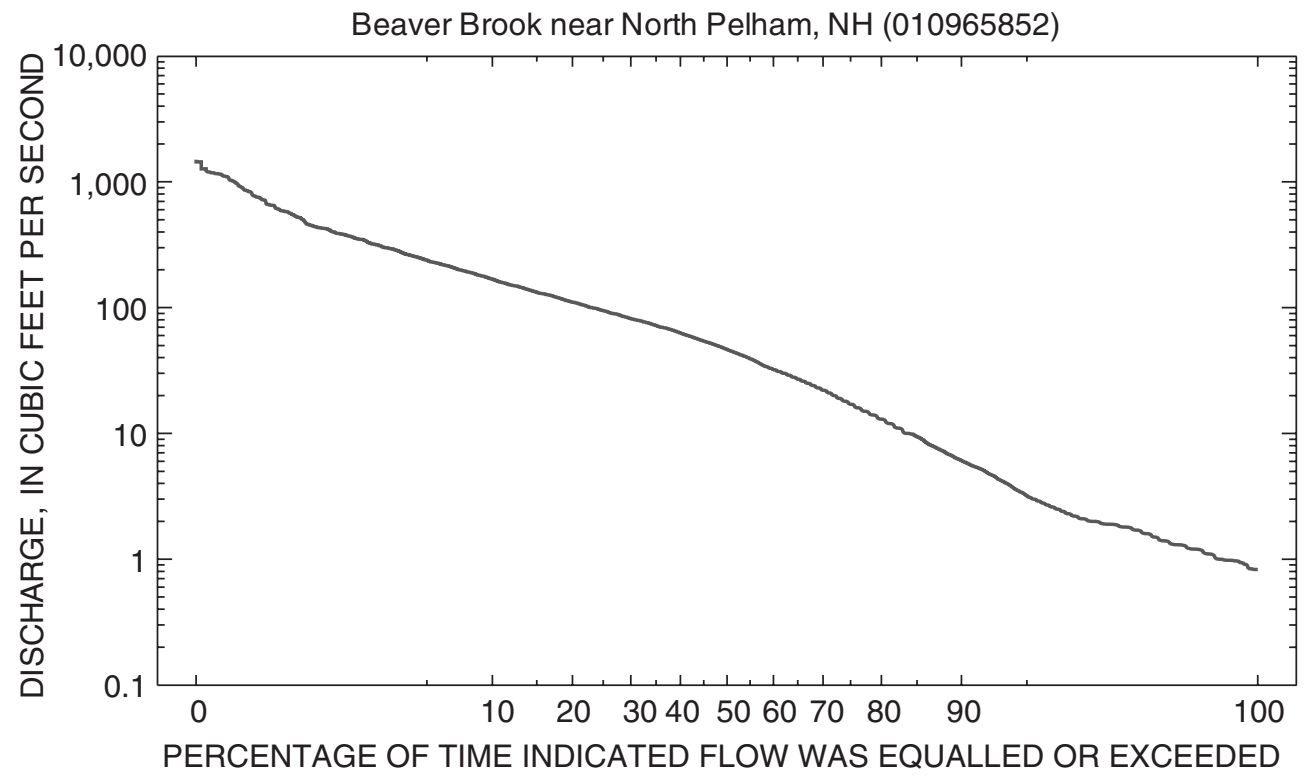

Figure 1-2. Annual flow-duration curve for Beaver Brook near Pelham, NH (010965852) for water years $1976-2000$. 
62 Streamflow Requirements and Streamflow Characteristics at Index Stations in Southern New England

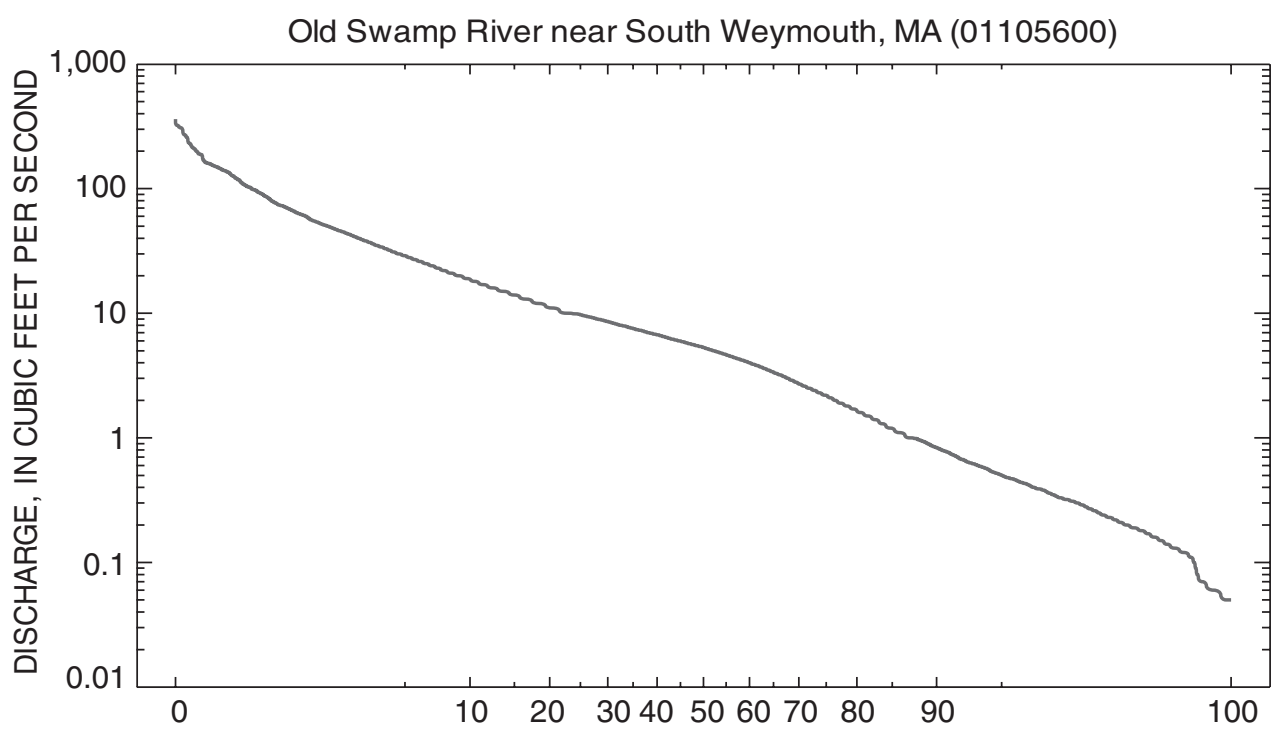

PERCENTAGE OF TIME INDICATED FLOW WAS EQUALLED OR EXCEEDED

Figure 1-3. Annual flow-duration curve for Old Swamp River near Weymouth, MA (01105600) for water years $1976-2000$.

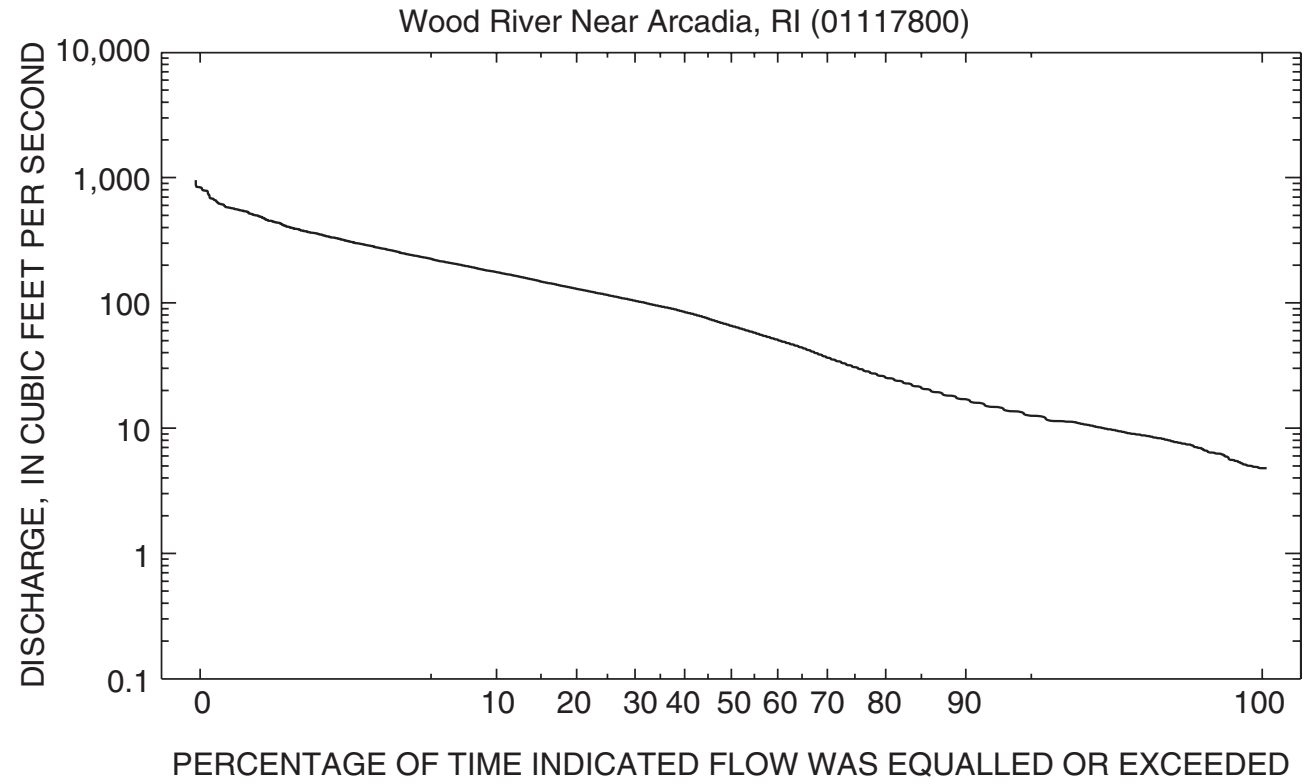

Figure 1-4. Annual flow-duration curve for Wood River near Arcadia, RI (01117800) for water years $1976-2000$. 


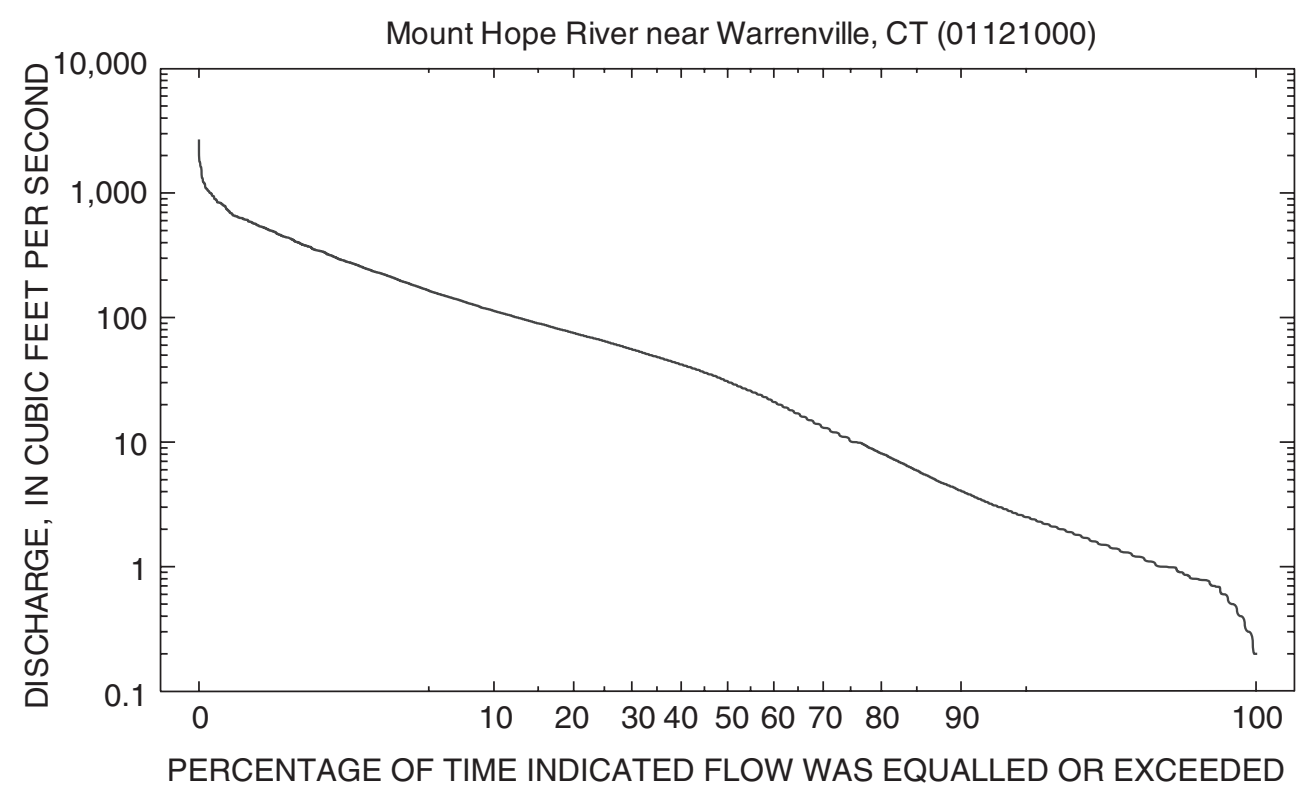

Figure 1-5. Annual flow-duration curve for Mount Hope near Warrenville, CT (01121000) for water years 1976-2000.

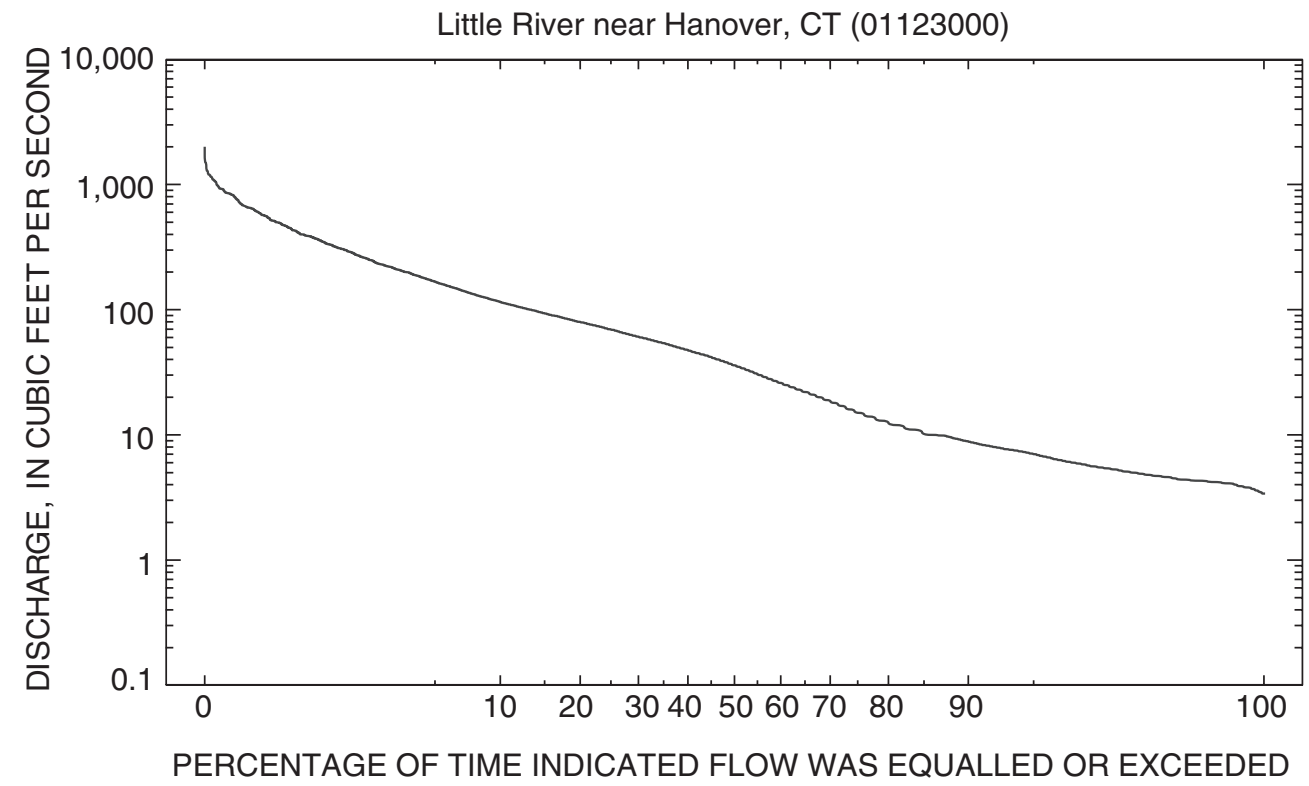

Figure 1-6. Annual flow-duration curve for Little River near Hanover, CT (01123000) for water years 1976-2000. 
South River Near Conway, MA (01169900)

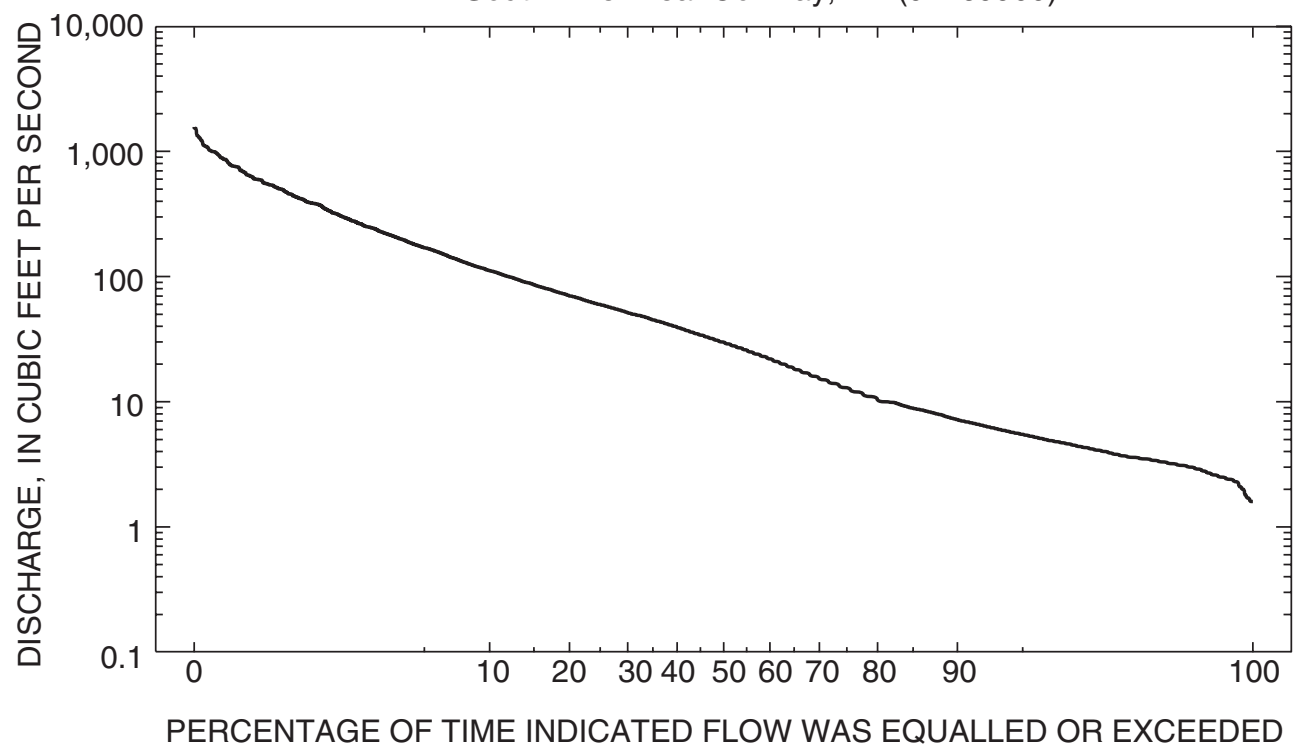

Figure 1-7. Annual flow-duration curve for South River near Conway, MA (01169900) for water years 1976-2000.

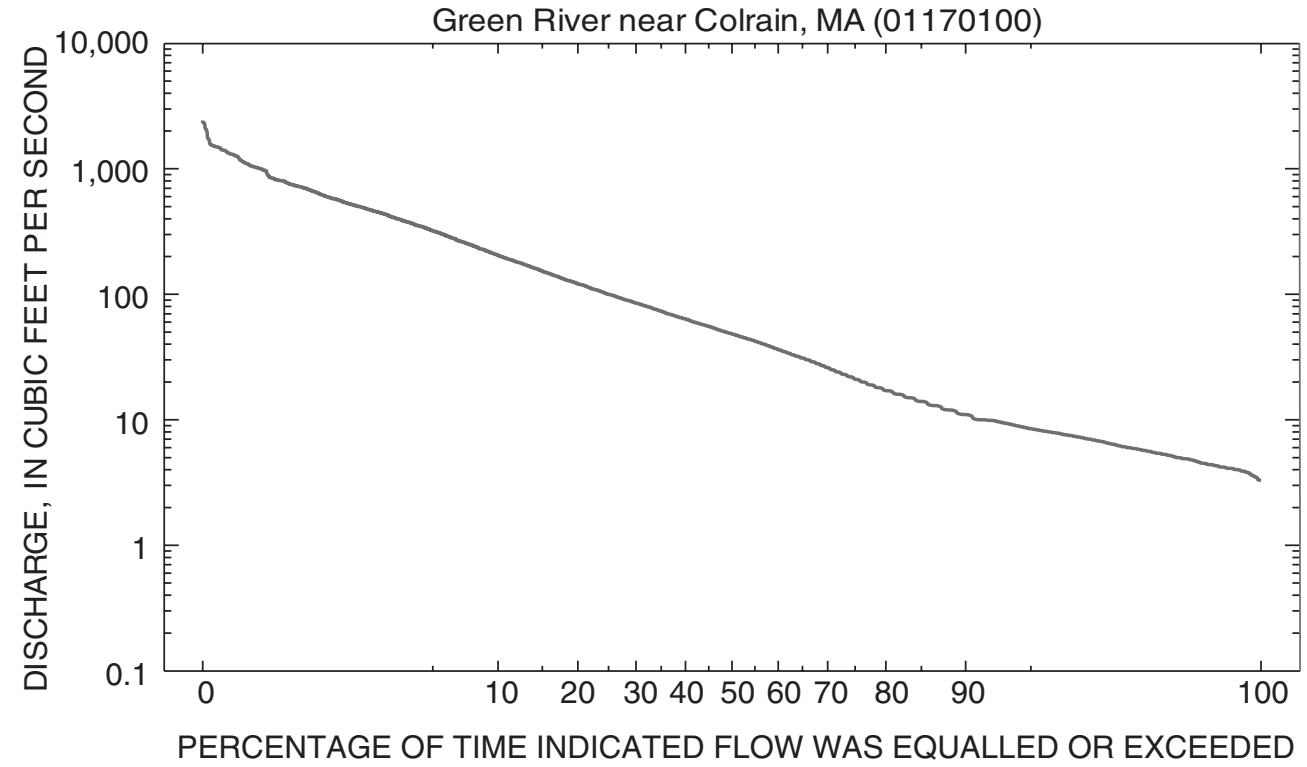

Figure 1-8. Annual flow-duration curve for Green River near Colrain, MA (01170100) for water years $1976-2000$. 


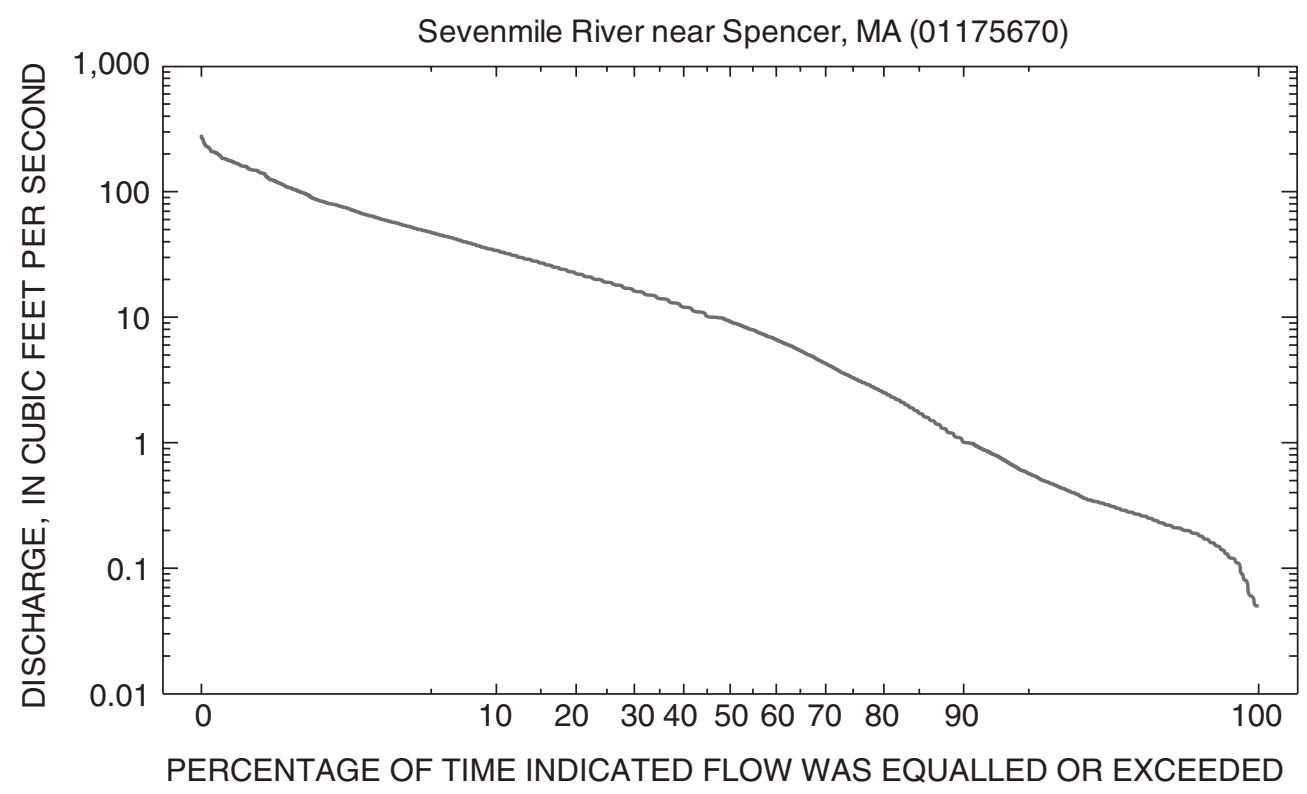

Figure 1-9. Annual flow-duration curve for Sevenmile River near Spencer, MA (01175670) for water years 1976-2000.

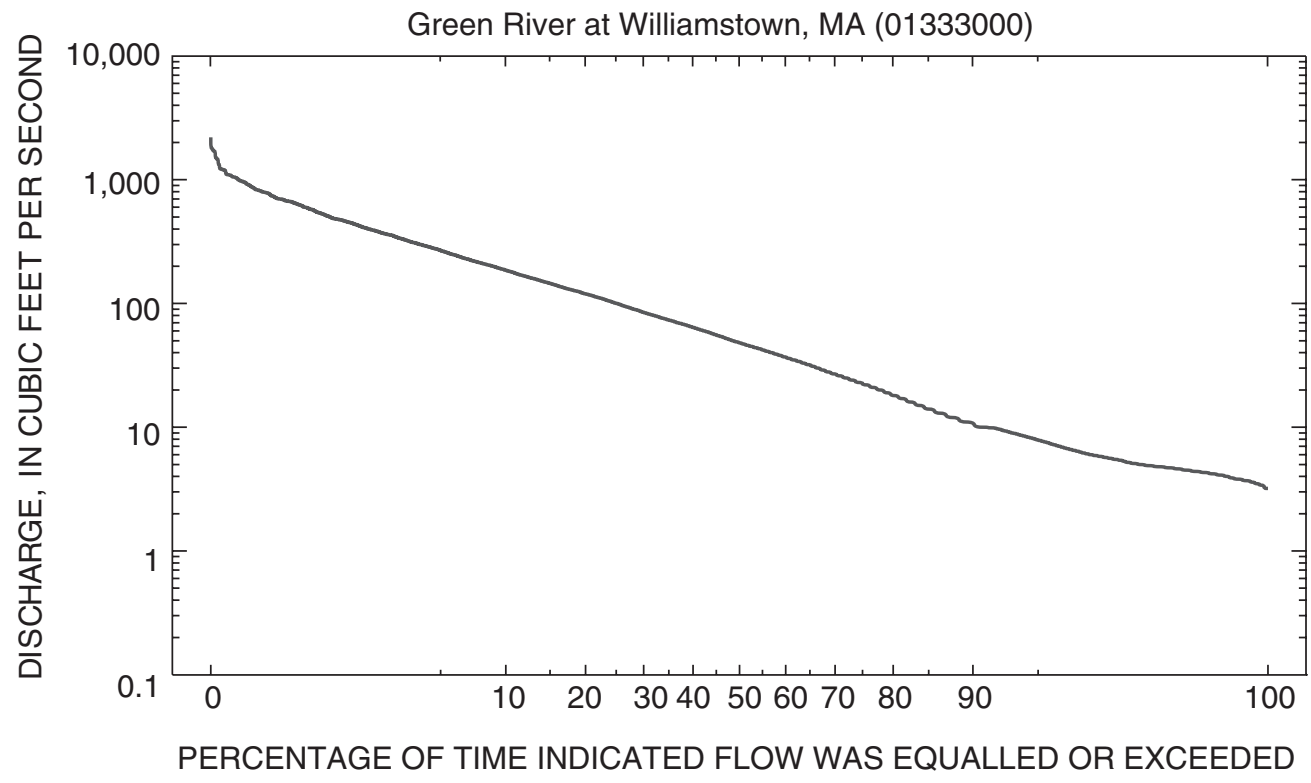

Figure 1-10. Annual flow-duration curve for Green River at Williamstown, MA (01333000) for water years 1976-2000. 



\section{Appendix 2: Procedures for Application of the Wetted-Perimeter Method.}



Appendix 2 details the procedures used for selection of cross sections, surveying, and determination of breakpoints during analysis for the Wetted-Perimeter method:

\section{Selection of Appropriate Cross Sections}

The Wetted-Perimeter method is best applied to straight reaches that have rectangular or trapezoidal cross-sections. Cross sections on bends, where the channel has a deep thalweg against the bank on the outside of the bend, and a point bar on the inside of the bend, should be avoided. Cross sections should be selected to avoid woody debris, large rocks, or other obstructions that extend above the water surface. The Wetted-Perimeter method is best applied in natural, alluvial channels that can adjust their depth, width, and slope. Application of the method to channels where the width of the stream channel has been altered (widened or narrowed), or where the streambanks have been hardened (such as by riprap or a stone wall), will likely increase the variability of streamflow requirements determined by the method.

\section{Surveying}

In general, at least $25-30$ points should be surveyed in each cross section. All breaks in slope should be surveyed during the cross-section survey, and enough detail should be collected to define areas where the cross section has a gradual change in slope. The bottom-of-bank should be identified in the field and surveyed. For reaches where there is no distinct bottom-of-bank, and the transition between the streambed and bank is gradual, several points defining the transition between streambed and bank should be surveyed, along with the top width required to fill the low-flow channel.

\section{Analysis}

A plot of wetted perimeter and discharge is required for each cross section. Plots of cross sections and wetted perimeter and water-surface elevation should also be made for each transect. Although several plots at a variety of scales can be useful, each cross section should also be plotted at a 1:1 scale. The left and right bottom-of-bank (BLB and BRB) should be identified on the plots of wetted perimeter and discharge, and wetted perimeter and water-surface elevation.
Frequently, the process for selection of the break points on the plots is similar for channels with similar channel geometry. In channels where the streambed is relatively flat, and the elevation of the channel bottom is less than the elevation of the bottom-of-bank, such as in a rectangular or trapezoidal channel with steep banks, the BLB and BRB typically define a narrow range of elevations that corresponds with a break in slope on the wetted-perimeter and discharge plot. This break point is used to determine the streamflow requirement. If there are multiple break ponts, the break point that is most closely associated with the elevations of the BLB and $\mathrm{BRB}$ is used to determine the streamflow requirement.

In a triangular or bowl-shaped channel, or trapezoidshaped channel in which one or both banks have a shallow slope, the BLB and BRB may not correspond with a break point on the wetted-perimeter and discharge plot. If the BLB and $\mathrm{BRB}$ are not near the same elevation, and there are no distinct break points between the BLB and BRB, the elevation that gives a fully wetted-channel bottom (generally the elevation corresponding to the bottom-of-bank at the higher elevation) is used to determine the Wetted-Perimeter streamflow requirement. If neither the bottom-of-bank nor the fully wetted-channel bottom can be clearly determined, the elevations of the BLB and BRB are averaged.

In channels where the geomorphic features of the channel bed are higher than the bottom of the bank, the fieldidentified BLB and BRB can be lower than the break point in the plot of wetted perimeter and discharge. In these channels, the discharge that provides a fully wetted channel bottom generally corresponds with a break point that is above the field-identified BLB and BRB. For cross sections where boulders in the channel extend above the bottom of the bank, break points on the wetted-perimeter and discharge plot are affected mostly by the shape of the rocks, and field information on the bottom-of-bank and fully wetted-channel bottom must be used to determine streamflow requirements. Determination of Wetted-Perimeter streamflow requirements is difficult for channels with complex shapes, such as may occur where the riffle is on a slight curve and is undercut on one side and has a bar on the other. For cross sections where the elevations of the BLB and BRB do not correspond, where there are no distinct break points between the BLB and BRB, or where the level that provides a fully wetted channel bottom is not clear, the cross section may not suitable for determining Wetted-Perimeter streamflow requirements. 

Appendix 3: Study-Site Descriptions, Documentation of Input, Calibration Data for HEC-RAS Models, and Hydraulic Variables Simulated by Calibrated HEC-RAS Models for 10 Index Streamflow-Gaging Stations in Southern New England 

Appendix 3 includes study-site descriptions and documentation for HEC-RAS models used to simulate hydraulic parameters for determination of Wetted-Perimeter and R2Cross streamflow requirements for:

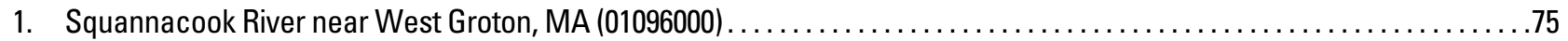

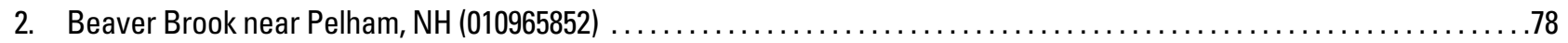

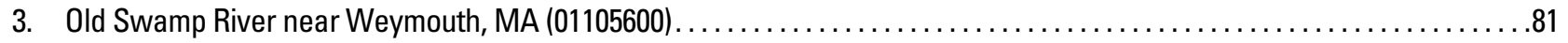

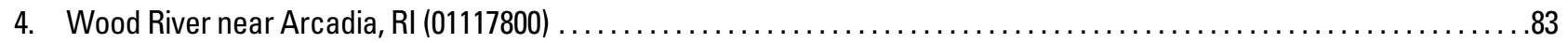

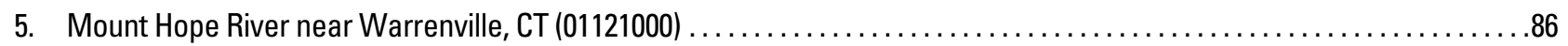

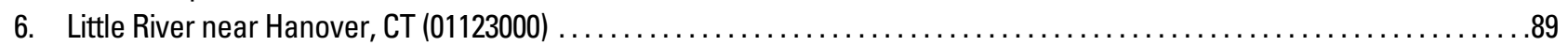

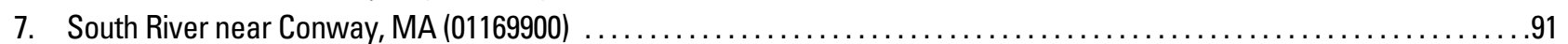

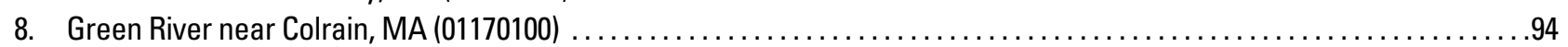

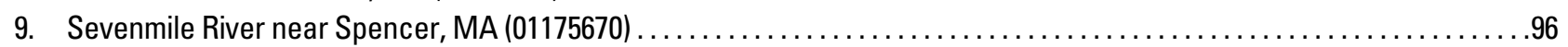

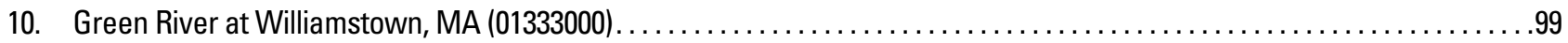



Graphs and cross-section plots generated from HEC-RAS model output and used for determination of Wetted-Perimeter streamflow requirements are available for inspection in project files at the Massachusetts-Rhode Island District Office. Values reported in the appendix for the hydraulic parameters used to determine R2Cross streamflow requirements (wetted perimeter, mean depth, mean velocity) are from the staging tables output by the HEC-RAS models. The staging tables were created for small incremental differences in discharge. For some cases, the hydraulic parameters that met the R2Cross criteria fell between successive discharges in the staging tables. For these cases, the discharge meeting the criteria and reported in the text was extrapolated between successive values in the staging table. Values in the appendix tables, however, are those for the discharge in the staging table where the criteria are first met. In all cases differences are minor.

\section{Squannacook River near West Groton, MA (01096000)}

The study reach on the Squannacook River is about $400 \mathrm{ft}$ downstream of the Squannacook River streamflow-gaging station (01096000) and cableway (fig. 3-1). The surveyed reach is about $300 \mathrm{ft}$ in overall length and is centered on a riffle study reach that is about $75 \mathrm{ft}$ in length. The riffle study reach begins at the upstream end of a cascade (about $100 \mathrm{ft}$ in length), and extends upstream to a small drop in the channel adjacent to a picnic area on the left bank. A small riffle that is the control for the streamflow-gaging station is upstream of the study reach.

The drainage area to the site is about $63.7 \mathrm{mi}^{2}$. The channel in the study reach is about 45 to $50 \mathrm{ft}$ wide. The study reach is within a straight segment of the river with a moderate gradient that contains mostly riffle habitat. The channel contains numerous boulders. Several of the larger rocks along the bank are bedrock. Bedrock in the channel at the upper end of the study creates a drop in the water surface of about $0.5 \mathrm{ft}$. A cascade at the downstream end of the study reach is separated from the study reach by an irregular-shaped bedrock control that creates a drop in the water surface of about $1 \mathrm{ft}$. There is a shelf or narrow flood plain along the left bank. The shelf is very narrow or nonexistent along the right bank. Riparian vegetation is shrubs and trees.

Although the channel in the study reach was altered historically, none of the channel alterations appear recent. The controls at the upstream and downstream ends of the study riffle include some large boulders that may be be remnants of dams. Several additional features indicate that the area was altered historically. Downstream of the study riffle, a stone wall supports the left bank through the cascade, and a large iron shaft near the left bank may have been part of a control or gate structure. Upstream of the study riffle is a low channel along the right bank that would convey flow and bypass the streamflowgaging station during high discharges. Dry channels and other historical diggings along the left bank upstream of the streamflow-gaging station also indicate that the area was altered in the past.

The study riffle is about $47 \mathrm{ft}$ wide. The stream channel in the riffle has a moderately steep slope. The water surface along the riffle drops about $1.1 \mathrm{ft}$ at $10 \mathrm{ft}^{3} / \mathrm{s}$, and $0.92 \mathrm{ft}$ at $180 \mathrm{ft}^{3} / \mathrm{s}$.

The riffle cross sections are predominantly trapezoidal in shape and have a uniform cross section within the riffle. The streambed substrate in the riffle is primarily cobble, boulder, and gravel, and the bank material is a mixture of gravel and sand.

Four cross sections were surveyed along a 65 -ft length of the riffle. The most upstream (station 204) and downstream (station 130) were near the breaks in slope at the upper and lower ends of the riffle. Reference points for measurement of water levels at different discharges were placed in the streambed at each cross section and in trees and along the bank upstream and downstream of the riffle study reach.

A HEC-RAS model was used to calculate water-surface profiles. The model was run for a subcritical flow regime by use of the standard, upstream-step energy method. Input data for the model included cross section geometry, estimated roughness coefficients, and initial boundary conditions. The cross sections at stations 130, 169, and 204 were used in the model, and no templated cross-sections were added. Initial roughness coefficients were determined for each cross section by backcalculation of Manning equation at the calibration discharges. Calibration discharges were 10,22, 65.3, 76, and $180 \mathrm{ft}^{3} / \mathrm{s}$. The calibration discharges were modeled at normal depth at the most downstream modeled section and a slope of 0.0055 was input as a downstream boundary condition. The slope was determined from averaging water-surface altitudes measured at different discharges.

For model calibration, water levels in the cross sections were measured at five different discharges ranging from $10 \mathrm{ft}^{3} / \mathrm{s}$ to $180 \mathrm{ft}^{3} / \mathrm{s}$. The stream discharges corresponding to the time of water-level measurements were determined from stagedischarge ratings at the nearby Squannacook River streamflowgaging station. The HEC-RAS model was calibrated by changing roughness coefficients for each cross section as required until calculated water-surface altitudes matched measured water-surface altitudes with reasonable accuracy. The calibration accuracy was $0.0103 \mathrm{ft}$ over the entire reach for the measured discharges.

The variability in the roughness coefficients between river stations (table 3.1) accounts for both the variability of roughness in the channel and along the banks between cross sections, and the difference between the actual flow-path lengths and the straight-line lengths between river stations. The longer flow paths taken by water to flow around bed material at different discharges decreases the energy slope. This is compensated for in the HEC-RAS model by increasing roughness coefficients. 


\section{Streamflow Requirements and Streamflow Characteristics at Index Stations in Southern New England}

During the site survey, field indicators of the bankfull water line were identified and surveyed at each cross section. These field indicators include features such as stain lines, the top of gravel bars, the upper extent of bank erosion and exposed roots, the base of large woody vegetation, and boundaries between aquatic and terrestrial vegetation. The discharge that best corresponded to the altitudes of the bankfull-water-line field indicators at all of the cross sections was determined from the calibrated HEC-RAS model to be about $250 \mathrm{ft}^{3} / \mathrm{s}$.

The calibrated HEC-RAS model was used to produce a staging table of hydraulic parameters for 49 discharges between 1 and $250 \mathrm{ft}^{3} / \mathrm{s}$ for the cross sections at stations 130,169 , and 204 , respectively. A staging table was created and used to determine the discharges at which the R2Cross streamflow requirements were met.

The R2Cross criteria for determining streamflow requirements at the cross sections at station 169 was a wetted perimeter of $26.4 \mathrm{ft}$, a mean depth of $0.52 \mathrm{ft}$, and a mean velocity of $1.0 \mathrm{ft} / \mathrm{s}$. These wetted-perimeter, mean-depth, and mean-velocity criteria were met or exceeded at discharges of $3.0,16.3$, and $31.4 \mathrm{ft}^{3} / \mathrm{s}$, respectively. The R2Cross criteria for determining streamflow requirements at the cross sections at station 204 were a wetted perimeter of $29.4 \mathrm{ft}$, a mean depth of $0.58 \mathrm{ft}$, and a mean velocity of $1.0 \mathrm{ft} / \mathrm{s}$. These wetted-perimeter, mean-depth, and mean-velocity criteria were met or exceeded at discharges of 8.1, 18.0, and $37 \mathrm{ft}^{3} / \mathrm{s}$, respectively. The average R2Cross streamflow requirement for the two cross sections, based on the streamflow that meets 2-of-3 hydraulic criteria, was $17.2 \mathrm{ft}^{3} / \mathrm{s}\left(0.27 \mathrm{ft}^{3} / \mathrm{s} / \mathrm{mi}^{2}\right)$. The average R2Cross streamflow requirement for two cross sections, based on the streamflow that meets all three hydraulic criteria, was $34.2 \mathrm{ft}^{3} / \mathrm{s}\left(0.53 \mathrm{ft}^{3} / \mathrm{s} / \mathrm{mi}^{2}\right)$.
Hydraulic characteristics at critical cross sections meeting R2Cross method criteria for habitat protection are summarized in table 3.2.

A wetted-perimeter/discharge relation was determined for the cross section at station 169 by use of plots of wetted perimeter versus discharge, water-surface elevation versus wetted perimeter, and cross-section output from the calibrated HEC-RAS model. Breaks in the wetted perimeter discharge relation that correspond to toe-of-bank elevations identified during site surveys were used to determine a Wetted-Perimeter streamflow requirement of about $22.5 \mathrm{ft}^{3} / \mathrm{s}$.

Breaks in the wetted perimeter/discharge relation that correspond to toe-of-bank elevations identified during site surveys were used to determine a Wetted-Perimeter streamflow requirement of about $14 \mathrm{ft}^{3} / \mathrm{s}$. For this discharge, the maximum channel depth was about $0.92 \mathrm{ft}$, the average water depth in the riffle was $0.48 \mathrm{ft}$, the mean velocity was $0.66 \mathrm{ft} / \mathrm{s}$, and the wetted perimeter was $44.4 \mathrm{ft}$ or 84 percent of the bankfull wetted perimeter.

A wetted-perimeter/discharge relation was determined for the cross section at station 204 on the basis of the HEC-RAS model results. Breaks in the wetted-perimeter/discharge relation that correspond to toe-of-bank elevations identified during site surveys were used to determine a Wetted-Perimeter streamflow requirement of about $31 \mathrm{ft}^{3} / \mathrm{s}$. For this discharge, the maximum channel depth was about $1.08 \mathrm{ft}$, the average water depth in the riffle was $0.53 \mathrm{ft}$, the mean velocity was $1.21 \mathrm{ft} / \mathrm{s}$, and the wetted perimeter was $48.4 \mathrm{ft}$ or 81 percent of the bankfull wetted perimeter.

The average Wetted-Perimeter streamflow requirement for the two cross sections was $22.5 \mathrm{ft}^{3} / \mathrm{s}\left(0.35 \mathrm{ft}^{3} / \mathrm{s} / \mathrm{mi}^{2}\right)$.

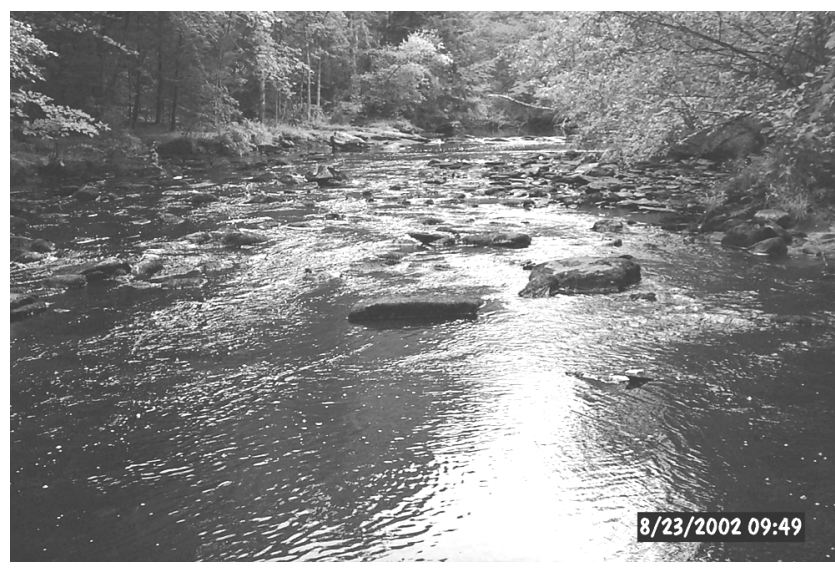

Figure 3-1. Riffle habitat on the Squannacook River near West Groton, MA, upstream view. 
Table 3-1. Hydraulic variables simulated by HEC-RAS for the streamflows used for model calibration, Squannacook River near West Groton, MA.

[River station: Numbers increase in an upstream direction. $\mathrm{ft}^{3} / \mathrm{s}$, cubic foot per second; $\mathrm{ft}$, foot; $\mathrm{ft} / \mathrm{ft}$, foot per foot; $\mathrm{ft}^{2}$, square foot; -, no data]

\begin{tabular}{|c|c|c|c|c|c|c|c|c|}
\hline $\begin{array}{l}\text { River } \\
\text { station }\end{array}$ & $\begin{array}{c}\text { Discharge } \\
\left(\mathrm{ft}^{3} / \mathrm{s}\right)\end{array}$ & $\begin{array}{l}\text { Manning's } \\
\text { coefficient }\end{array}$ & $\begin{array}{l}\text { Flow } \\
\text { area } \\
\left(\mathrm{ft}^{2}\right)\end{array}$ & $\begin{array}{l}\text { Hydraulic } \\
\text { radius } \\
\text { (ft) }\end{array}$ & $\begin{array}{l}\text { Energy grade } \\
\text { slope } \\
\text { (ft/ft) }\end{array}$ & $\begin{array}{l}\text { Froude } \\
\text { number }\end{array}$ & $\begin{array}{l}\text { Calculated water- } \\
\text { surface altitude } \\
\text { (ft) }\end{array}$ & $\begin{array}{l}\text { Observed water- } \\
\text { surface altitude } \\
\text { (ft) }\end{array}$ \\
\hline 130 & 10.0 & 0.388 & 37.9 & 0.89 & 0.0055 & 0.05 & 495.15 & 495.15 \\
\hline 130 & 22.0 & .261 & 48.9 & 1.10 & .0055 & . 07 & 495.41 & 495.41 \\
\hline 130 & 65.3 & .141 & 66.4 & 1.40 & .0055 & .14 & 495.8 & 495.8 \\
\hline 130 & 76.0 & .131 & 69.4 & 1.50 & .0055 & .16 & 495.87 & 495.87 \\
\hline 130 & 180 & .084 & 90.4 & 1.90 & .0055 & .25 & 496.33 & 496.32 \\
\hline 169 & 10.0 & .400 & 16.7 & .39 & .0901 & .17 & 495.70 & 495.69 \\
\hline 169 & 22.0 & .383 & 27.7 & .59 & .0840 & .18 & 495.93 & 495.94 \\
\hline 169 & 65.3 & .098 & 36.9 & .77 & .0194 & .35 & 496.13 & 496.14 \\
\hline 169 & 76.0 & .129 & 42.5 & .87 & .0286 & .33 & 496.28 & 496.26 \\
\hline 169 & 180 & .152 & 67.5 & 1.30 & .0506 & .40 & 496.78 & 496.77 \\
\hline 204 & 10.0 & .066 & 11.1 & .34 & .0069 & .27 & 496.28 & 496.29 \\
\hline 204 & 22.0 & .066 & 19.7 & .47 & .0068 & .29 & 496.50 & 496.51 \\
\hline 204 & 65.3 & .093 & 35.2 & .72 & .0209 & .38 & 496.85 & 496.84 \\
\hline 204 & 76.0 & .086 & 40.8 & .83 & .0150 & .36 & 496.98 & 496.96 \\
\hline 204 & 180 & .041 & 55.4 & 1.10 & .0072 & .54 & 497.25 & 497.26 \\
\hline
\end{tabular}

Table 3-2. Hydraulic variables simulated by HEC-RAS for the streamflows meeting R2Cross criteria for determination of streamflows for habitat protection, Squannacook River near West Groton, MA.

$\left[\mathrm{ft}^{3} / \mathrm{s}\right.$, cubic foot per second; $\mathrm{ft}$, foot; $\mathrm{ft} / \mathrm{s}$, foot per second]

\begin{tabular}{|c|c|c|c|c|c|c|c|}
\hline $\begin{array}{l}\text { River } \\
\text { station }\end{array}$ & $\begin{array}{c}\text { Discharge } \\
\left(\mathrm{ft}^{3} / \mathrm{s}\right)\end{array}$ & $\begin{array}{l}\text { Top width } \\
\text { (ft) }\end{array}$ & $\begin{array}{c}\text { Wetted } \\
\text { perimeter } \\
\text { (ft) }\end{array}$ & $\begin{array}{c}\text { Average } \\
\text { velocity } \\
\text { (ft/s) }\end{array}$ & $\begin{array}{l}\text { Average } \\
\text { depth } \\
\text { (ft) }\end{array}$ & $\begin{array}{c}\text { Maximum } \\
\text { depth } \\
\text { (ft) }\end{array}$ & Notes \\
\hline 169 & 31.4 & -- & 47.3 & 1.00 & 0.67 & 1.14 & Meets 3-of-3 criteria. \\
\hline 169 & 16.3 & -- & 45.3 & .70 & .52 & .97 & Meets 2-of-3 criteria. \\
\hline 204 & 18.0 & -- & 41.2 & 1.00 & .44 & .90 & Meets 2 -of- 3 criteria. \\
\hline
\end{tabular}




\section{Beaver Brook at North Pelham, NH (010965852)}

The study reach on Beaver Brook is about $200 \mathrm{ft}$ downstream of Mammoth Road and just downstream of the control for the Beaver Brook streamflow-gaging station (010965852) on Beaver Brook at North Pelham, NH (fig. 3-2). The study reach is about $150 \mathrm{ft}$ in length and is centered on a riffle just downstream of a sharp meander where the channel bends to the right to parallel Mammoth Road.

The drainage area to the site is about $47.8 \mathrm{mi}^{2}$. The channel in the study reach is about 35 to $45 \mathrm{ft}$ wide. The study reach is within a moderate gradient segment of the river that contains riffle, run, and pool habitats. The river in this reach has no flood plain, although there is a small grass bench on the left side of the channel. Vegetation along the banks are dominated by large white pine, deciduous trees, and shrubs. Shrubs along the right bank have been removed. The riffle site is in the middle of the study reach. At the upper end of the study reach is a deep scour pool downstream of Mammoth Road. This pool is the gage pool for the Beaver Brook streamflow-gaging station, which is on the right bank. Large rocks in the channel at the bend create the control for the gage pool. Downstream of the control, the channel continues to bend to the right and then straightens through the riffle study reach. Along the right bank on the inside of the bend is a gravel bar that is exposed at low flows. Along the left banks are large rocks that may have been emplaced as rip rap. A few rocks that may be bedrock are exposed in the left bank away from the channel. These rocks, together with the riprap, appear to restrict channel migration. A run at the downstream end of the riffle grades into glide and pool habitat downstream.

The channel in the study reach has several alterations. The upstream gage pool is a scour pool formed just downstream of a road crossing. Large boulders may have been emplaced on the control and also as riprap along the outside of the bend. Erosion of soil from the right bank has undercut the bank, undercutting tree roots and causing several trees to drop into the channel. A large tree that was in the channel during reconnaissance in 2001 was removed prior to field data collection in 2002. In some areas removal of shrub vegetation along the right bank may have decreased bank stability.

The study riffle is about $35 \mathrm{ft}$ to $45 \mathrm{ft}$ wide. The stream channel in the riffle has a moderately steep slope. The water surface along the riffle drops about $1.13 \mathrm{ft}$ at $1.7 \mathrm{ft}^{3} / \mathrm{s}$, and $0.21 \mathrm{ft}$ at $143 \mathrm{ft}^{3} / \mathrm{s}$. The riffle cross sections are mostly trapezoidal in shape, but the streambed has an irregular cross section within the riffle created by bedrock, boulders, and the gravel bar. The streambed substrate in the riffle is primarily cobble, boulder, and gravel, and the bank material is mostly sand, with a few boulders and possibly some bedrock along the left side of the channel.

Four cross sections were surveyed along a 70-ft length of the riffle along with a reference point about $100 \mathrm{ft}$ downstream. The most upstream and downstream cross sections (stations 155 and 93) were near the breaks in slope at the upper and lower ends of the riffle. The downstream cross section was in the pool at the base of the riffle. This cross section was affected by backwater at low discharges. Reference points for measurement of water levels at different discharges were placed in the streambed at each cross section and in trees upstream and downstream of the riffle along the right bank.

A HEC-RAS model was used to calculate water-surface profiles. The model was run for a subcritical flow regime by use of the standard, upstream-step energy method. Input data for the model included cross section geometry, estimated roughness coefficients, and initial boundary conditions. Cross sections at stations 93, 122, 134, and 155 were used in the model. Initial roughness coefficients were determined for each cross section by back-calculation of Manning Equation at the calibration discharges. Calibration discharges were 1.70, 4.0, 10.0, 24.0, 100 , and $143 \mathrm{ft}^{3} / \mathrm{s}$. The calibration discharges were modeled at normal depth at the most downstream section and a slope of $0.008 \mathrm{ft} / \mathrm{ft}$ was input as a boundary condition. This slope was calculated from water-surface altitudes measured at the downstream end of the reach.

For model calibration, water levels in the cross sections were measured at six different discharges, ranging from $1.7 \mathrm{ft}^{3} / \mathrm{s}$ to $143 \mathrm{ft}^{3} / \mathrm{s}$. The stream discharges corresponding to the time of water-level measurements were determined from stagedischarge ratings at the Beaver Brook streamflow-gaging station. Discharges were computed by the USGS New Hampshire district to compensate for a correction to the record for this station.

The HEC-RAS software occasionally indicated the need for more cross sections to reduce velocity head drops between sections. Addition of interpolated cross sections would reduce the number of these messages, but would not significantly affect the water-surface profile. Interpolated cross sections were required between stations $155,134,122$, and 93 for calibration of the model. The HEC-RAS model was calibrated by changing vertical roughness coefficients for each cross section as required until calculated water-surface altitudes matched measured water-surface altitudes with reasonable accuracy. The calibration accuracy was 0.0 for most calibration discharges except for two measurements where the modeled stages differed from measured stages by 0.02 and $0.01 \mathrm{ft}$. The calibration accuracy was $0.005 \mathrm{ft}$ over the entire reach for the measured discharges.

The variability in the roughness coefficients between river stations (table 3-3) accounts for both the roughness in the channel and along the banks between cross sections, and the difference between the actual flow path lengths and the straightline lengths between river stations. The longer flow paths taken by water to flow around bed material at different discharges decreases the energy slope. This is compensated for in the HEC-RAS model by increasing roughness coefficients.

During the site survey, field indicators of the bankfull water line were identified and surveyed at each cross section. These field indicators include features such as stain lines, the top of gravel bars, the upper extent of bank erosion and exposed roots, the base of large woody vegetation, and boundaries between aquatic and terrestrial vegetation. The discharge that 
best corresponded to the altitudes of the bankfull-water-line field indicators at all of the cross sections was determined from the calibrated HEC-RAS model to be about $110 \mathrm{ft}^{3} / \mathrm{s}$.

Observations of water levels during a high flow event indicated that the MAHW indicators were underwater at a discharge of $143 \mathrm{ft}^{3} / \mathrm{s}$.

The calibrated HEC-RAS model was used to produce a staging table of hydraulic parameters for 49 discharges between 1.0 and $143 \mathrm{ft}^{3} / \mathrm{s}$ for river stations $93,122,134$, and 155 , respectively. Cross sections at stations 122,134 , and 155 did not have backwater conditions and were selected for R2Cross analysis. A staging table was created and used to determine the discharges at which the $\mathrm{R} 2 \mathrm{Cross}$ streamflow requirements were met.

The R2Cross criteria for determining streamflow requirements at the cross section at station 122 were a wetted perimeter of $22.5 \mathrm{ft}$, a mean depth of $0.44 \mathrm{ft}$, and a mean velocity of $1.0 \mathrm{ft} / \mathrm{s}$. These wetted perimeter, mean depth, and mean velocity criteria were met or exceeded at discharges of $1.5,13$, and $20.0 \mathrm{ft}^{3} / \mathrm{s}$, respectively. The R2Cross criteria for determining streamflow requirements at the cross section at station 134 were a wetted perimeter of $18.5 \mathrm{ft}$, a mean depth of $0.36 \mathrm{ft}$, and a mean velocity of $1.0 \mathrm{ft} / \mathrm{s}$. These wetted perimeter, mean velocity, and mean depth criteria were met or exceeded at discharges of less than $1,10.5$, and $13.5 \mathrm{ft}^{3} / \mathrm{s}$, respectively. The R2Cross criteria for determining streamflow requirements at the cross section at station 155 were a wetted perimeter of $20.0 \mathrm{ft}$, a mean depth of $0.39 \mathrm{ft}$, and a mean velocity of $1.0 \mathrm{ft} / \mathrm{s}$.
These wetted perimeter, mean depth, and mean velocity criteria were met or exceeded at discharges of less than 1, 4.7, and $22.9 \mathrm{ft}^{3} / \mathrm{s}$, respectively. The average R2Cross streamflow requirement for the three cross sections, based on the streamflow that meets 2-of-3 hydraulic criteria, was $9.4 \mathrm{ft}^{3} / \mathrm{s}$ $\left(0.20 \mathrm{ft}^{3} / \mathrm{s} / \mathrm{mi}^{2}\right)$. The average R2Cross streamflow requirement for the two cross sections, based on the streamflow that meets all three hydraulic criteria, was $18.8 \mathrm{ft}^{3} / \mathrm{s}\left(0.39 \mathrm{ft}^{3} / \mathrm{s} / \mathrm{mi}^{2}\right)$.

Hydraulic characteristics at critical cross sections meeting R2Cross method criteria for habitat protection are summarized in table 3.4.

A Wetted-Perimeter streamflow requirement was determined for the cross sections at stations 122, 134, and 155, by use of plots of wetted perimeter versus discharge, watersurface elevation versus wetted perimeter, and cross-sections output from the calibrated HEC-RAS model. Breaks in the wetted perimeter discharge relation that correspond to toe-ofbank elevations identified during site surveys were used to determine a Wetted-Perimeter streamflow requirement of about 5 and $6 \mathrm{ft}^{3} / \mathrm{s}$ for station 122 and 134, respectively. Toe-of-bank elevations identified during site surveys were used to determine a Wetted-Perimeter streamflow requirement of about $8 \mathrm{ft}^{3} / \mathrm{s}$ for station 155. For these discharges, the maximum channel depth was about $0.87,0.90$, and $0.97 \mathrm{ft}$, and the average water depth in the riffle was $0.39,0.42$, and $0.48 \mathrm{ft}$, respectively. The average Wetted-Perimeter streamflow requirement for the three cross sections was $6.3 \mathrm{ft}^{3} / \mathrm{s}\left(0.13 \mathrm{ft}^{3} / \mathrm{s} / \mathrm{mi}^{2}\right)$.

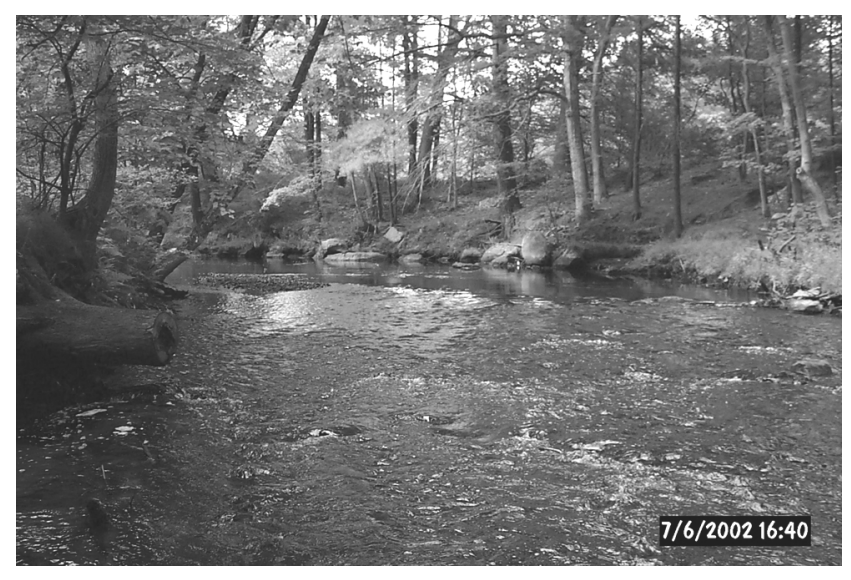

Figure 3-2. Riffle habitat on Beaver Brook at North Pelham, $\mathrm{NH}$, upstream view. 
80 Streamflow Requirements and Streamflow Characteristics at Index Stations in Southern New England

Table 3-3. Hydraulic variables simulated by HEC-RAS for the streamflows used for model calibration, Beaver Brook at North Pelham, $\mathrm{NH}$.

[River station: Numbers increase in an upstream direction. $\mathrm{ft}^{3} / \mathrm{s}$, cubic foot per second; $\mathrm{ft}$, foot; $\mathrm{ft} / \mathrm{ft}$, foot per foot; $\mathrm{ft}^{2}$, square foot; -, no data]

\begin{tabular}{|c|c|c|c|c|c|c|c|c|}
\hline $\begin{array}{l}\text { River } \\
\text { station }\end{array}$ & $\begin{array}{c}\text { Discharge } \\
\left(\mathrm{ft}^{3} / \mathrm{s}\right)\end{array}$ & $\begin{array}{l}\text { Manning's } \\
\text { coefficient }\end{array}$ & $\begin{array}{l}\text { Flow } \\
\text { area } \\
\left(\mathrm{ft}^{2}\right)\end{array}$ & $\begin{array}{l}\text { Hydraulic } \\
\text { radius } \\
\text { (ft) }\end{array}$ & $\begin{array}{l}\text { Energy grade } \\
\text { slope } \\
\text { (ft/ft) }\end{array}$ & $\begin{array}{l}\text { Froude } \\
\text { number }\end{array}$ & $\begin{array}{l}\text { Calculated water- } \\
\text { surface altitude } \\
\text { (ft) }\end{array}$ & $\begin{array}{l}\text { Observed water- } \\
\text { surface altitude } \\
\text { (ft) }\end{array}$ \\
\hline 93 & 1.70 & 0.072 & 2.64 & 0.21 & 0.0080 & 0.25 & 485.77 & 485.77 \\
\hline 93 & 4.00 & .085 & 5.55 & .31 & .0080 & .23 & 485.97 & 485.97 \\
\hline 93 & 10.0 & .204 & 22.8 & .55 & .0080 & .10 & 486.53 & 486.53 \\
\hline 93 & 24.0 & . 155 & 33.4 & .76 & .0080 & .14 & 486.78 & 486.78 \\
\hline 93 & 100 & .139 & 76.9 & 1.58 & .0080 & .18 & 487.73 & -- \\
\hline 93 & 143 & .139 & 96.2 & 1.90 & .0080 & .19 & 488.12 & 488.12 \\
\hline 122 & 1.70 & .166 & 5.43 & .21 & .0097 & .12 & 486.39 & 486.39 \\
\hline 122 & 4.00 & .222 & 12.5 & .34 & .0094 & .10 & 486.62 & 486.63 \\
\hline 122 & 10.0 & .150 & 14.9 & .40 & .0157 & .19 & 486.68 & 486.68 \\
\hline 122 & 24.0 & .100 & 21.5 & .54 & .0127 & .27 & 486.85 & 486.85 \\
\hline 122 & 100 & .025 & 58.6 & 1.32 & .0006 & .26 & 487.73 & 487.73 \\
\hline 122 & 143 & .070 & 79.8 & 1.72 & .0033 & .24 & 488.21 & 488.21 \\
\hline 134 & 1.70 & .200 & 4.86 & .17 & .0242 & .15 & 486.78 & 486.80 \\
\hline 134 & 4.00 & .166 & 7.22 & .23 & .0273 & .20 & 486.86 & -- \\
\hline 134 & 10.0 & .119 & 10.3 & .30 & .0303 & .31 & 486.95 & 486.95 \\
\hline 134 & 24.0 & .075 & 17.2 & .49 & .0129 & .35 & 487.15 & 487.15 \\
\hline 134 & 100 & .072 & 40.3 & 1.10 & .0126 & .41 & 487.81 & -- \\
\hline 134 & 143 & .070 & 55.4 & 1.46 & .0086 & .37 & 488.23 & 488.23 \\
\hline 155 & 1.70 & .140 & 8.28 & .26 & .0023 & .07 & 486.90 & 486.90 \\
\hline 155 & 4.00 & .140 & 12.5 & .36 & .0035 & .09 & 487.03 & 487.03 \\
\hline 155 & 10.0 & .160 & 19.4 & .52 & .0073 & .13 & 487.22 & 487.22 \\
\hline 155 & 24.0 & .074 & 23.1 & .61 & .0052 & .23 & 487.32 & 487.32 \\
\hline 155 & 100 & .025 & 44.6 & 1.13 & .0012 & .37 & 487.88 & 487.88 \\
\hline 155 & 143 & .043 & 62.2 & 1.52 & .0025 & .32 & 488.33 & 488.33 \\
\hline
\end{tabular}

Table 3-4. Hydraulic variables simulated by HEC-RAS for the streamflows meeting R2Cross criteria for determination of streamflows for habitat protection, Beaver Brook at North Pelham, NH.

$\left[\mathrm{ft}^{3} / \mathrm{s}\right.$, cubic foot per second; $\mathrm{ft}$, foot; ft/s, foot per second]

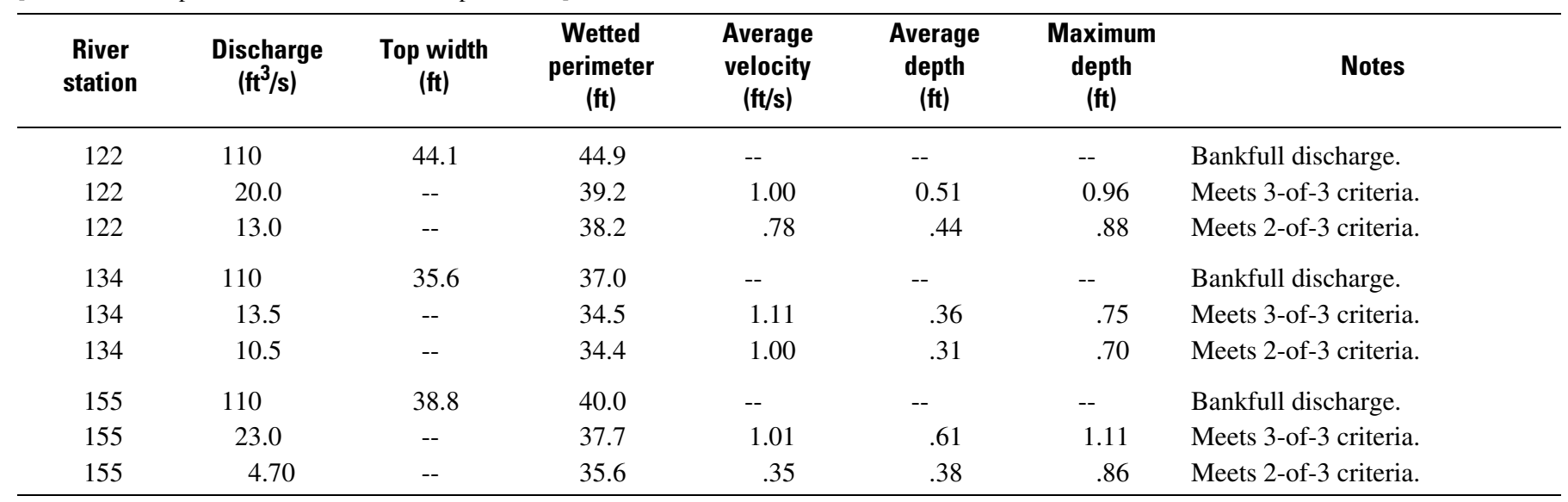




\section{Old Swamp River near South Weymouth, MA (01105600)}

The study reach on the Old Swamp River is about $1,200 \mathrm{ft}$ downstream of the Old Swamp River streamflowgaging station (01105600) between Industrial Road and Whitman Pond (fig. 3-3). The site is adjacent to a private access road owned by the Weymouth Water Supply. The riffle study reach begins at the head of a riffle about 200 downstream of Industrial Road, where an old road cut and ford associated with a power line crosses the channel, and extends downstream about $100 \mathrm{ft}$ to a location adjacent with a brick pump house near the left bank. There are pools upstream and downstream of the study reach.

The drainage area to the site is about $4.5 \mathrm{mi}^{2}$. The channel in the study reach is slightly less than $20 \mathrm{ft}$ wide. The study reach is within a moderate-gradient segment of the river that contains mostly riffle habitat. The channel contains gravel, cobble, and sand. Riparian vegetation is shrubs and trees.

Streamflows at the riffle site may possibly be altered by induced infiltration to nearby Weymouth Water Supply wells. The channel in the study reach has been altered historically. The roadcut and ford adjacent to the power-line crossing have altered the stream banks at the head of the riffle. The flood plain downstream of the power line is irregular in shape, and there are mounds of earth adjacent to the channel that may be fill. However, none of the channel or flood plain alterations appear recent. Sediment discharge to the river could potentially be influenced by runoff upstream of the study reach from Industrial Road and Route 3, development along Industrial Road, or a nearby gravel pit.

The study riffle is about $20 \mathrm{ft}$ wide. The stream channel in the riffle has a moderate slope. The water surface along the riffle drops about $0.41 \mathrm{ft}$ at $1.7 \mathrm{ft}^{3} / \mathrm{s}$, and $0.39 \mathrm{ft}$ at $7.8 \mathrm{ft}^{3} / \mathrm{s}$. The riffle cross sections are predominantly trapezoidal in shape and generally have a uniform cross section within the riffle. The streambed substrate in the riffle is primarily gravel, cobble, and sand, and the bank material is a mixture of gravel and sand. The channel shape is uniform along its length.

Six cross sections were surveyed along a 100-ft length of the riffle. The most upstream cross section (station 199) and downstream cross section (station 100) were near the breaks in slope at the upper and lower ends of the riffle. Reference points for measurement of water levels at different discharges were placed in the streambed at each cross section and in trees and along the bank upstream and downstream of the riffle study reach.

A HEC-RAS model was used to calculate water-surface profiles. The model was run for a subcritical flow regime by use of the standard, upstream-step energy method. Input data for the model included cross section geometry, estimated roughness coefficients, and initial boundary conditions. All surveyed cross sections were included in the HEC-RAS model. Two templated cross sections were added between stations 100 and 147, three templated cross sections were added between stations 147 and 160 , and 160 and 172, and one templated cross section was added between stations 189 and 199 .

For model calibration, water levels in the cross sections were measured at five different discharges, ranging from $0.23 \mathrm{ft}^{3} / \mathrm{s}$ to $7.8 \mathrm{ft}^{3} / \mathrm{s}$ (table 3-5). Initial roughness coefficients were determined for each cross section by back-calculation of Manning Equation at the calibration discharges. The calibration discharges were modeled at normal depth at the most downstream modeled section and a slope of $0.0025 \mathrm{ft} / \mathrm{ft}$ was input as a downstream boundary condition. This slope was determined by averaging stream slopes determined from measurements of water-surface altitudes made at different discharges.

The discharges used for model calibration $(0.23,1.7,4.0$, and $7.8 \mathrm{ft}^{3} / \mathrm{s}$ ) were determined from stage-discharge ratings at the Old Swamp River streamflow-gaging station. The HECRAS model was calibrated by changing roughness coefficients for each cross section as required until calculated water-surface altitudes matched measured water-surface altitudes with reasonable accuracy. The calibration accuracy was $0.0189 \mathrm{ft}$ over the entire reach for the measured discharges.

Indicators of the bankfull water line were identified in the field. Discharges that corresponded to the bankfull water line were determined from the calibrated model to be about $35 \mathrm{ft}^{3} / \mathrm{s}$.

The calibrated HEC-RAS model was used to produce a staging table of hydraulic parameters for 49 discharges between 1 and $100 \mathrm{ft}^{3} / \mathrm{s}$ for stations 100 through 199 , respectively. The staging table was used to determine streamflow requirements using R2Cross criteria (table 3-6).

The limiting R2Cross criterion or last of the three criteria to be met was the mean velocity at for all four stations. The second criterion to be met at each station was mean depth. The average R2Cross streamflow requirement for the four cross sections, based on the streamflow that meets two of three hydraulic criteria, was $1.3 \mathrm{ft}^{3} / \mathrm{s}\left(0.29 \mathrm{ft}^{3} / \mathrm{s} / \mathrm{mi}^{2}\right)$. The average R2Cross streamflow requirement for the four cross sections, based on the streamflow that meets all three hydraulic criteria, was $7.85 \mathrm{ft}^{3} / \mathrm{s}\left(1.74 \mathrm{ft}^{3} / \mathrm{s} / \mathrm{mi}^{2}\right)$.

A wetted perimeter-discharge relation was determined for the cross sections at stations $160,172,189$, and 199 on the basis of the HEC-RAS model results. Breaks in the wetted perimeter discharge relation that correspond to toe-of-bank elevations identified during site surveys were used to determine a WettedPerimeter streamflow requirement of about 1.0, 3.0, 1.7, and 3.0 $\mathrm{ft}^{3} / \mathrm{s}$ for cross sections at stations $160,172,189$, and 199. For these stations, the average maximum channel depths were about $0.42,0.42,0.60$, and $0.51 \mathrm{ft}$; the average mean water depth in the riffle were $0.18,0.24,0.27$, and $0.36 \mathrm{ft}$, the average mean velocities were $0.35,0.62,0.35$, and $0.45 \mathrm{ft} / \mathrm{s}$, and the average wetted perimeters were $86,93,79$, and 91 percent of the bankfull wetted perimeter, respectively.

The average Wetted-Perimeter streamflow requirement for the four cross sections was $2.18 \mathrm{ft}^{3} / \mathrm{s}$ or $0.48 \mathrm{ft}^{3} / \mathrm{s} / \mathrm{mi}^{2}$. 


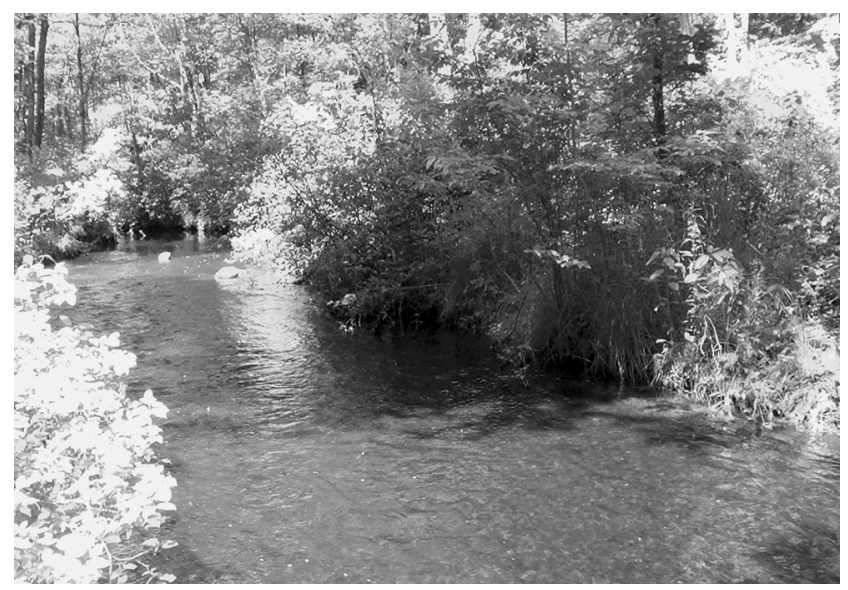

Figure 3-3. Riffle habitat on the Old Swamp River near South Weymouth, MA, upstream view.

Table 3-5. Hydraulic variables simulated by HEC-RAS for the streamflows used for model calibration, Old Swamp River near South Weymouth, MA.

[River station: Numbers increase in an upstream direction. $\mathrm{ft}^{3} / \mathrm{s}$, cubic foot per second; $\mathrm{ft}$, foot; $\mathrm{ft} / \mathrm{ft}$, foot per foot; $\mathrm{ft}^{2}$, square foot; -, no data]

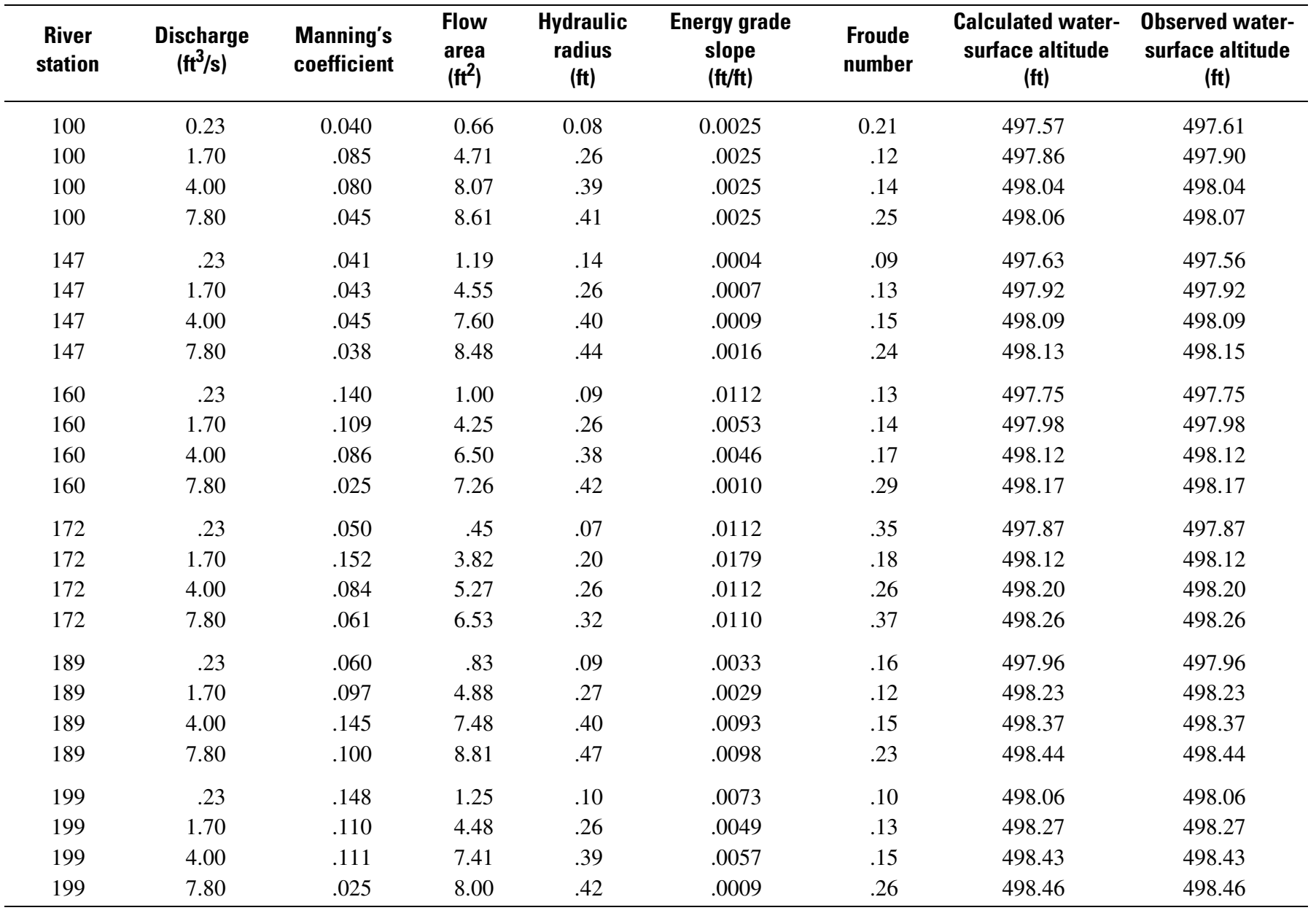


Table 3-6. Hydraulic variables simulated by HEC-RAS for the streamflows meeting R2Cross criteria for determination of streamflows for habitat protection, Old Swamp River near South Weymouth, MA.

[ $\mathrm{ft}^{3} / \mathrm{s}$, cubic foot per second; $\mathrm{ft}$, foot; $\mathrm{ft} / \mathrm{s}$, foot per second]

\begin{tabular}{|c|c|c|c|c|c|c|c|}
\hline $\begin{array}{l}\text { River } \\
\text { station }\end{array}$ & $\begin{array}{c}\text { Discharge } \\
\left(\mathrm{ft}^{3} / \mathrm{s}\right)\end{array}$ & $\begin{array}{c}\text { Top width } \\
\text { (ft) }\end{array}$ & $\begin{array}{c}\text { Wetted } \\
\text { perimeter } \\
\text { (ft) }\end{array}$ & $\begin{array}{c}\text { Average } \\
\text { velocity } \\
\text { (ft/s) }\end{array}$ & $\begin{array}{c}\text { Average } \\
\text { depth } \\
\text { (ft) }\end{array}$ & $\begin{array}{l}\text { Maximum } \\
\text { depth } \\
\text { (ft) }\end{array}$ & Notes \\
\hline 160 & 7.40 & 16.9 & 17.3 & 1.00 & .44 & .69 & Meets 3-of-3 criteria. \\
\hline 160 & 1.20 & 15.9 & 16.2 & .37 & .20 & .44 & Meets 2-of-3 criteria. \\
\hline 172 & 1.75 & 19.2 & 19.3 & .46 & .20 & .37 & Meets 2-of-3 criteria. \\
\hline 189 & 35.0 & 19.0 & 20.2 & 1.83 & 1.00 & 1.37 & Bankfull discharge. \\
\hline 189 & 9.80 & 18.3 & 19.1 & 1.00 & .53 & .88 & Meets 3-of-3 criteria. \\
\hline 189 & 1.10 & 17.0 & 17.2 & .32 & .20 & .52 & Meets 2-of-3 criteria. \\
\hline
\end{tabular}

\section{Wood River near Arcadia, RI (01117800)}

The study reach on Wood River is about $500 \mathrm{ft}$ downstream of the Wood River streamflow-gaging station (01117800) downstream of Ten Rod Road (Route 165) in the Arcadia Management Area (fig. 3-4). The site is just downstream of the parking area at the end of the access road for the Quonset Hut, a popular fisherman access. The study reach begins at the head of a riffle about 100 downstream of the parking area, and extends downstream about $120 \mathrm{ft}$ to the foot of the riffle, and then an additional $200 \mathrm{ft}$ downstream through run and pool habitat. The reach just upstream of the study riffle is a long pool.

The drainage area to the site is about $35.2 \mathrm{mi}^{2}$. The study reach is within a moderate gradient segment of the river that contains mostly riffle habitat. The channel contains gravel, cobble, and sand. Riparian vegetation is shrubs, deciduous trees, and white pine. The channel upstream of the study reach has been altered. There is a parking area on the right bank between the study area and Route 165 road crossing, and the stream bank in this area has been cleared of vegetation. The riffle study area, channel, and riparian areas downstream appear natural, although there is some evidence that some larger boulders have been moved or emplaced possibly to create trout habitat.

The stream channel in the study reach is about 40 to $50 \mathrm{ft}$ wide. The channel has a moderate slope, and the water surface along the riffle drops about $0.41 \mathrm{ft}$ at $9.3 \mathrm{ft}^{3} / \mathrm{s}$, and $0.26 \mathrm{ft}$ at $156 \mathrm{ft}^{3} / \mathrm{s}$. The riffle cross sections are predominantly trapezoidal in shape and generally have a uniform cross section within the riffle. The channel is mostly straight, with a slight bend to the left. The water along the right bank is shallower, and there is a low shelf along right bank. Streambed substrate in the riffle is primarily gravel, cobble, and sand, and the bank material is a mixture of gravel and sand.

Four cross sections were surveyed along a $120-\mathrm{ft}$ length of the riffle. The most upstream cross section (station 300) and downstream cross section (station 100) were near the breaks in slope at the upper and lower ends of the riffle. Reference points for measurement of water levels at different discharges were placed in the streambed at each cross section and in trees and along the left bank downstream of the riffle study reach.

A HEC-RAS model was used to calculate water-surface profiles. The model was run for a subcritical flow regime by use of the standard, upstream-step energy method. Input data for the model included cross section geometry, estimated roughness coefficients, and initial boundary conditions. All surveyed cross sections were included in the HEC-RAS model. Two templated cross-sections were added between stations 300 and 201.

For model calibration, water levels in the cross sections were measured at six different discharges, ranging from $9.3 \mathrm{ft}^{3} / \mathrm{s}$ to $156 \mathrm{ft}^{3} / \mathrm{s}$ (table 3.7). Initial roughness coefficients were determined for each cross section by back-calculation of Manning Equation at the calibration discharges. The calibration discharges were modeled at normal depth at the most downstream modeled section and a slope of $0.0075 \mathrm{ft} / \mathrm{ft}$ was input as a downstream boundary condition. This slope was determined by averaging stream slopes determined from measurements of water-surface altitudes made at different discharges.

The discharges used for model calibration $(9.3,28,52,59$, 74.5 , and $156 \mathrm{ft}^{3} / \mathrm{s}$ ) were determined from stage-discharge ratings at the Wood River streamflow-gaging station. The HECRAS model was calibrated by changing roughness coefficients 
for each cross section as required until calculated water-surface altitudes matched measured water-surface altitudes with reasonable accuracy. The calibration accuracy was $0.0 \mathrm{ft}$ over the entire reach for the measured discharges.

Indicators of the bankfull water line were identified in the field. Discharges that corresponded to the bankfull water line were determined from the calibrated model to be about $110 \mathrm{ft}^{3} / \mathrm{s}$.

The calibrated HEC-RAS model was used to produce a staging table of hydraulic parameters for 49 discharges between 1 and $140 \mathrm{ft}^{3} / \mathrm{s}$ for stations 135 through 300, respectively. The staging table was used to determine streamflow requirements using R2Cross criteria (table 3.8).

The limiting R2Cross criterion or last of the three criteria to be met was the mean velocity at for all three stations. The second criterion to be met at each station was mean depth. The average R2Cross streamflow requirement for the three cross sections, based on the streamflow that meets two of three hydraulic criterion, was $17.4 \mathrm{ft}^{3} / \mathrm{s}\left(0.49 \mathrm{ft}^{3} / \mathrm{s} / \mathrm{mi}^{2}\right)$. The average R2Cross streamflow requirement for the three cross sections, based on the streamflow that meets all three hydraulic criteria, was $25.8 \mathrm{ft}^{3} / \mathrm{s}\left(0.73 \mathrm{ft}^{3} / \mathrm{s} / \mathrm{mi}^{2}\right)$.

A wetted-perimeter/discharge relation was determined for stations 135, 201, and 300 on the basis of the HEC-RAS model results (table 3.8). The average Wetted-Perimeter streamflow requirement for the three cross sections was $11.66 \mathrm{ft}^{3} / \mathrm{s}$ $\left(0.33 \mathrm{ft}^{3} / \mathrm{s} / \mathrm{mi}^{2}\right)$. Breaks in the wetted-perimeter/discharge relation that correspond to toe-of-bank elevations identified during site surveys were used to determine a Wetted-Perimeter streamflow requirement of about $18,5.0$, and $12 \mathrm{ft}^{3} / \mathrm{s}$ for stations 135,201 , and 300, respectively. For these stations, the average maximum channel depths were about $0.68,0.52$, and $0.80 \mathrm{ft}$; the average mean water depths in the riffle were 0.47 , 0.28 , and $0.40 \mathrm{ft}$, the average mean velocities were $0.92,0.45$, and $0.64 \mathrm{ft} / \mathrm{s}$, and the average wetted perimeters were 88,87 , and 93 percent of the bankfull wetted perimeter, respectively.

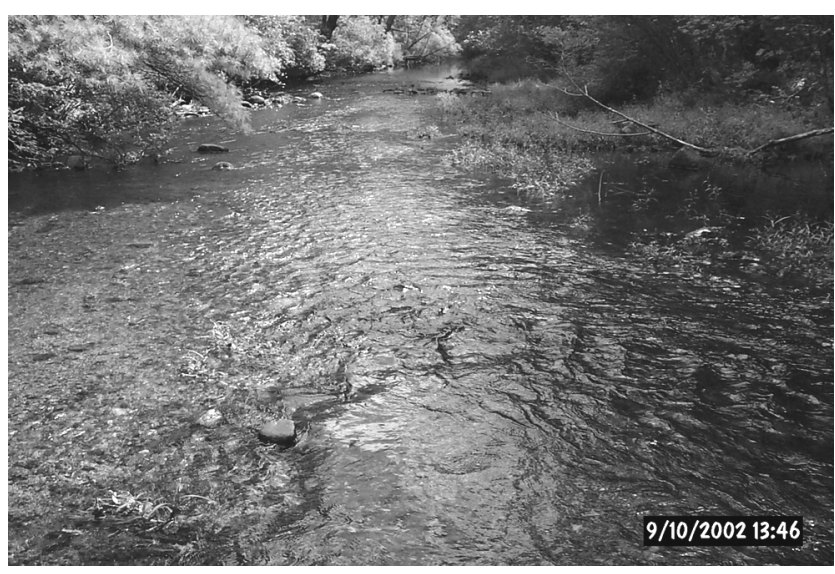

Figure 3-4. Riffle habitat on the Wood River near Arcadia, RI, downstream view. 
Table 3-7. Hydraulic variables simulated by HEC-RAS for the streamflows used for model calibration, Wood River near Arcadia, RI.

[River station: Numbers increase in an upstream direction. $\mathrm{ft}^{3} / \mathrm{s}$, cubic foot per second; $\mathrm{ft}$, foot; $\mathrm{ft} / \mathrm{ft}$, foot per foot; $\mathrm{ft}^{2}$, square foot; -, no data]

\begin{tabular}{|c|c|c|c|c|c|c|c|c|}
\hline $\begin{array}{l}\text { River } \\
\text { station }\end{array}$ & $\begin{array}{c}\text { Discharge } \\
\left(\mathrm{ft}^{3} / \mathrm{s}\right)\end{array}$ & $\begin{array}{l}\text { Manning's } \\
\text { coefficient }\end{array}$ & $\begin{array}{l}\text { Flow } \\
\text { area } \\
\left(\mathrm{ft}^{2}\right)\end{array}$ & $\begin{array}{l}\text { Hydraulic } \\
\text { radius } \\
\text { (ft) }\end{array}$ & $\begin{array}{l}\text { Energy grade } \\
\text { slope } \\
\text { (ft/ft) }\end{array}$ & $\begin{array}{l}\text { Froude } \\
\text { number }\end{array}$ & $\begin{array}{l}\text { Calculated water- } \\
\text { surface altitude } \\
\text { (ft) }\end{array}$ & $\begin{array}{l}\text { Observed water- } \\
\text { surface altitude } \\
\text { (ft) }\end{array}$ \\
\hline 100 & 9.30 & 0.135 & 16.2 & 0.47 & 0.0075 & 0.15 & 497.64 & 497.64 \\
\hline 100 & 28.0 & .104 & 27.8 & .73 & .0075 & .21 & 497.96 & -- \\
\hline 100 & 52.0 & .083 & 35.9 & .90 & .0075 & .27 & 498.17 & 498.17 \\
\hline 100 & 59.0 & .080 & 38.1 & .94 & .0075 & .28 & 498.23 & 498.23 \\
\hline 100 & 74.5 & .075 & 42.6 & 1.03 & .0075 & .30 & 498.34 & 498.34 \\
\hline 100 & 156 & .096 & 86.7 & 1.52 & .0075 & .25 & 499.19 & 499.19 \\
\hline 135 & 9.30 & .030 & 11.2 & .31 & .0013 & .26 & 497.73 & 497.73 \\
\hline 135 & 28.0 & .037 & 24.1 & .61 & .0017 & .26 & 498.07 & -- \\
\hline 135 & 52.0 & .042 & 33.7 & .83 & .0024 & .30 & 498.31 & 498.31 \\
\hline 135 & 59.0 & .038 & 35.5 & .87 & .0022 & .31 & 498.35 & 498.35 \\
\hline 135 & 74.5 & .038 & 40.1 & .98 & .0024 & .33 & 498.47 & -- \\
\hline 135 & 156 & .040 & 73.5 & 1.66 & .0016 & .28 & 499.28 & 499.28 \\
\hline 201 & 9.30 & .398 & 14.7 & .35 & .1151 & .19 & 497.87 & 497.87 \\
\hline 201 & 28.0 & .04 & 25.8 & .59 & .0017 & .25 & 498.13 & 498.13 \\
\hline 201 & 52.0 & .039 & 37.0 & .82 & .0018 & .27 & 498.38 & 498.38 \\
\hline 201 & 59.0 & .05 & 39.8 & .88 & .0030 & .28 & 498.44 & 498.44 \\
\hline 201 & 74.5 & .048 & 45.2 & .99 & .0029 & .29 & 498.56 & -- \\
\hline 201 & 156 & .035 & 80.4 & 1.69 & .0010 & .26 & 499.34 & 499.34 \\
\hline 300 & 9.30 & .13 & 16.6 & .36 & .0094 & .16 & 498.05 & 498.05 \\
\hline 300 & 28.0 & .10 & 29.9 & .58 & .0082 & .22 & 498.32 & 498.32 \\
\hline 300 & 52.0 & .14 & 43.8 & .83 & .0160 & .23 & 498.59 & 498.59 \\
\hline 300 & 59.0 & .17 & 47.1 & .88 & .0242 & .23 & 498.65 & 498.65 \\
\hline 300 & 74.5 & .07 & 49.9 & .93 & .0055 & .27 & 498.70 & 498.70 \\
\hline 300 & 156 & .14 & 90.3 & 1.61 & .0141 & .24 & 499.45 & 499.45 \\
\hline
\end{tabular}

Table 3-8. Hydraulic variables simulated by HEC-RAS for the streamflows meeting R2Cross criteria for determination of streamflows for habitat protection, Wood River near Arcadia, RI.

$\left[\mathrm{ft}^{3} / \mathrm{s}\right.$, cubic foot per second; $\mathrm{ft}$, foot; $\mathrm{ft} / \mathrm{s}$, foot per second]

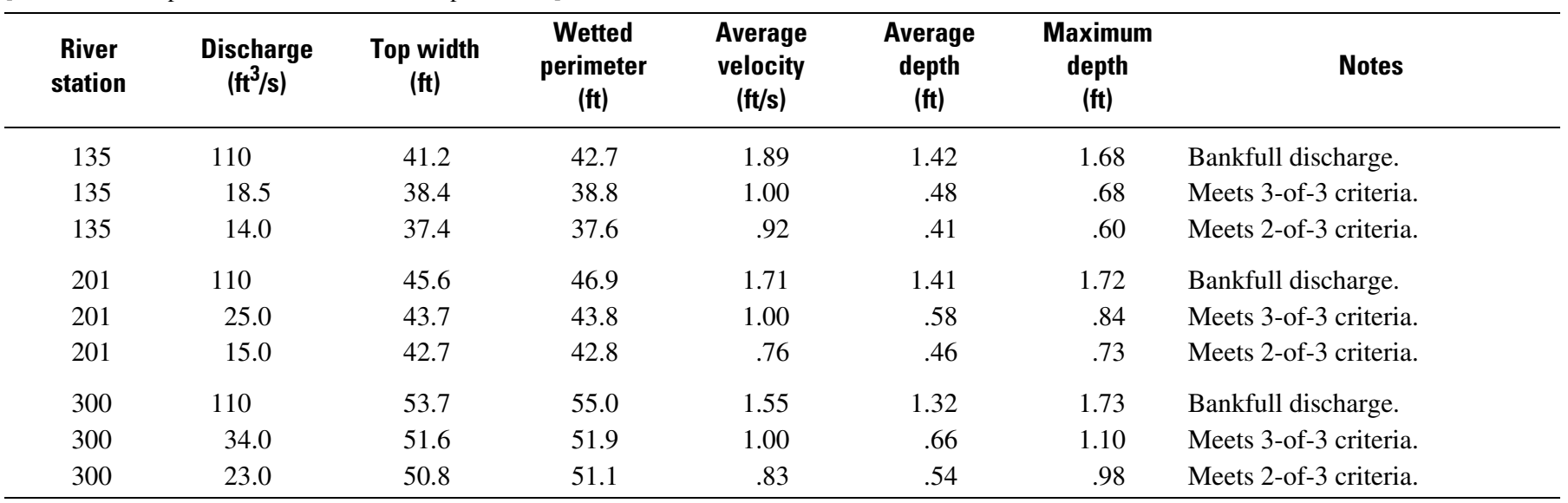




\section{Mount Hope River near Warrenville, CT (01121000)}

The study reach on the Mount Hope River is about $300 \mathrm{ft}$ downstream of the Mount Hope River streamflow-gaging station (01121000) and $200 \mathrm{ft}$ upstream of State Route 89 (fig. 3-5). The site is just upstream of an abandoned paved road that branches off from Lawrence Cushman Road and ends at the right bank of the river upstream of the Route 89 bridge. The study reach begins at the head of a riffle that is downstream of the control for the streamflow-gaging station, and extends downstream about $190 \mathrm{ft}$ to the foot of the riffle adjacent to the abandoned paved road. The reach just upstream and downstream of the study riffle is pool habitat.

The drainage area to the site is about $28.6 \mathrm{mi}^{2}$. The study reach is within a moderate gradient segment of the river that contains mostly riffle, run, and pool habitat. The channel contains gravel, cobble, and sand. Riparian vegetation is predominantly deciduous trees. The channel and immediate riparian area appears natural, although historically there may have been a bridge crossing at the downstream end of the study area, and gravel may have been removed from the riparian area near the right bank upstream of the study reach.

The stream channel in the study reach is about 35 to $50 \mathrm{ft}$ wide. The channel has a moderate slope, and the water surface along the riffle drops about $0.72 \mathrm{ft}$ at $0.9 \mathrm{ft}^{3} / \mathrm{s}$, and $0.56 \mathrm{ft}$ at $53 \mathrm{ft}^{3} / \mathrm{s}$. The riffle becomes a run at higher discharges, for example the drop in water surface was only $0.06 \mathrm{ft}$ at a discharge of $293 \mathrm{ft}^{3} / \mathrm{s}$. The channel is incised and has steep, high banks. The riffle cross sections are predominantly trapezoidal in shape and generally have a uniform cross section within the riffle. The channel is mostly straight. Streambed substrate in the riffle is primarily gravel, cobble, and sand, and the bank material is a mixture of gravel and sand.

Five cross sections were surveyed along a $120 \mathrm{ft}$ length of the riffle. The most upstream cross section (station 192) and downstream cross section (station 100) were near the breaks in slope at the upper and lower ends of the riffle. Reference points for measurement of water levels at different discharges were placed in the streambed at each cross section and in trees and along the right bank downstream of the riffle study reach.

A HEC-RAS model was used to calculate water-surface profiles. The model was run for a subcritical flow regime by use of the standard, upstream-step energy method. Input data for the model included cross section geometry, estimated roughness coefficients, and initial boundary conditions. All surveyed cross sections were included in the HEC-RAS model. Templated cross sections were added between stations 145 and 167, and between 167 and 192.

For model calibration, water levels in the cross sections were measured at eight different discharges, ranging from $0.88 \mathrm{ft}^{3} / \mathrm{s}$ to $293 \mathrm{ft}^{3} / \mathrm{s}$ (table 3.9). Initial roughness coefficients were determined for each cross section by back-calculation of Manning Equation at the calibration discharges. The calibration discharges were modeled at normal depth at the most downstream modeled section and a slope of $0.01 \mathrm{ft} / \mathrm{ft}$ was input as a downstream boundary condition. This slope was determined by averaging stream slopes determined from measurements of water-surface altitudes made at different discharges.

The discharges used for model calibration $(0.88,4.70$, 7.70, 12.0, 26.0, 35.5, 53.0, and $293 \mathrm{ft}^{3} / \mathrm{s}$ ) were determined from stage-discharge ratings at the Mount Hope River streamflow-gaging station. The HEC-RAS model was calibrated by changing roughness coefficients for each cross section as required until calculated water-surface altitudes matched measured water-surface altitudes with reasonable accuracy. The calibration accuracy was $0.042 \mathrm{ft}$ over the entire reach for the measured discharges.

Indicators of the bankfull water line were identified in the field. Discharges that corresponded to the bankfull water line were determined from the calibrated model to be about $65 \mathrm{ft}^{3} / \mathrm{s}$.

The calibrated HEC-RAS model was used to produce a staging table of hydraulic parameters for 49 discharges between 1 and $250 \mathrm{ft}^{3} / \mathrm{s}$ for stations $118,145,167,192$, respectively. The staging table was used to determine streamflow requirements by using R2Cross criteria (table 3.10).

The limiting R2Cross criterion or last of the three criteria to be met was the mean velocity for the cross sections at stations 145,167 , and 192, and mean depth for the cross section at station 118. The second criterion to be met at each station was mean depth for stations 145, 167, and 192, and mean velocity for stations 118. The average R2Cross streamflow requirement for the four cross sections, based on the streamflow that meets two of three hydraulic criteria, was $10.0 \mathrm{ft}^{3} / \mathrm{s}\left(0.35 \mathrm{ft}^{3} / \mathrm{s} / \mathrm{mi}^{2}\right)$. The average $\mathrm{R} 2 \mathrm{Cross}$ streamflow requirement for the four cross sections, based on the streamflow that meets all three hydraulic criteria, was $17.7 \mathrm{ft}^{3} / \mathrm{s}\left(0.61 \mathrm{ft}^{3} / \mathrm{s} / \mathrm{mi}^{2}\right)$.

A wetted-perimeter/discharge relation was determined for the cross sections at stations $118,145,167$, and 192 on the basis of the HEC-RAS model results. The average WettedPerimeter streamflow requirement for the four cross sections was $13.75 \mathrm{ft}^{3} / \mathrm{s}$ or $0.48 \mathrm{ft}^{3} / \mathrm{s} / \mathrm{mi}^{2}$. Breaks in the wettedperimeter/discharge relation that correspond to toe-of-bank elevations identified during site surveys were used to determine a Wetted-Perimeter streamflow requirement of about 18, 16, 8.0 , and $13 \mathrm{ft}^{3} / \mathrm{s}$ for cross sections at stations $118,145,167$, and 192 , respectively. For these stations, the maximum channel depths were about $0.6,0.59,0.85$ and $.99 \mathrm{ft}$; the average mean water depths in the riffle were $0.39,0.38,0.56$ and $0.46 \mathrm{ft}$, the average mean velocities were 1.02, 0.71, 0.84 and $1.06 \mathrm{ft} / \mathrm{s}$, and the average wetted perimeters were $74,79,86$ and 88 percent of the bankfull wetted perimeter, respectively. 


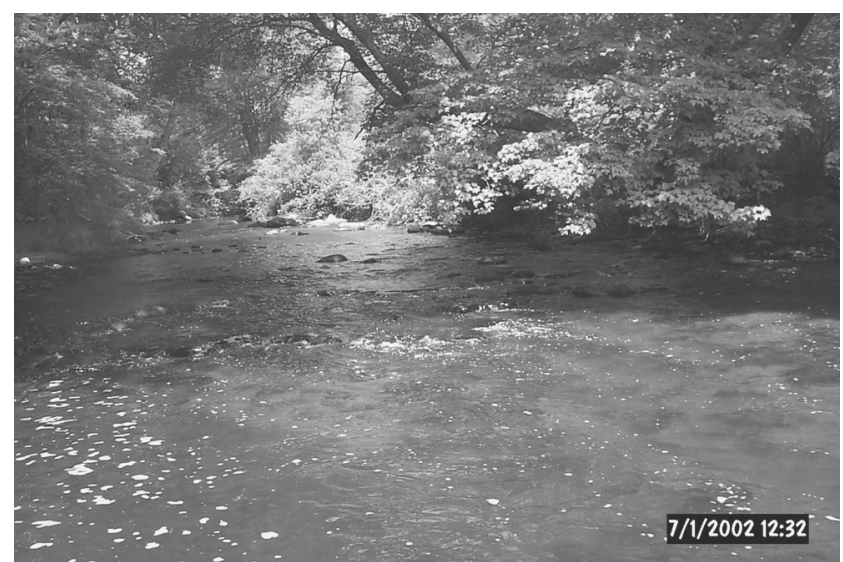

Figure 3-5. Riffle habitat on the Mount Hope River near Warrenville, CT, upstream view.

Table 3-9. Hydraulic variables simulated by HEC-RAS for the streamflows used for model calibration, Mount Hope River, CT.

[River station: Numbers increase in an upstream direction. $\mathrm{ft}^{3} / \mathrm{s}$, cubic foot per second; $\mathrm{ft}$, foot; $\mathrm{ft} / \mathrm{ft}$, foot per foot; $\mathrm{ft}^{2}$, square foot; -, no data]

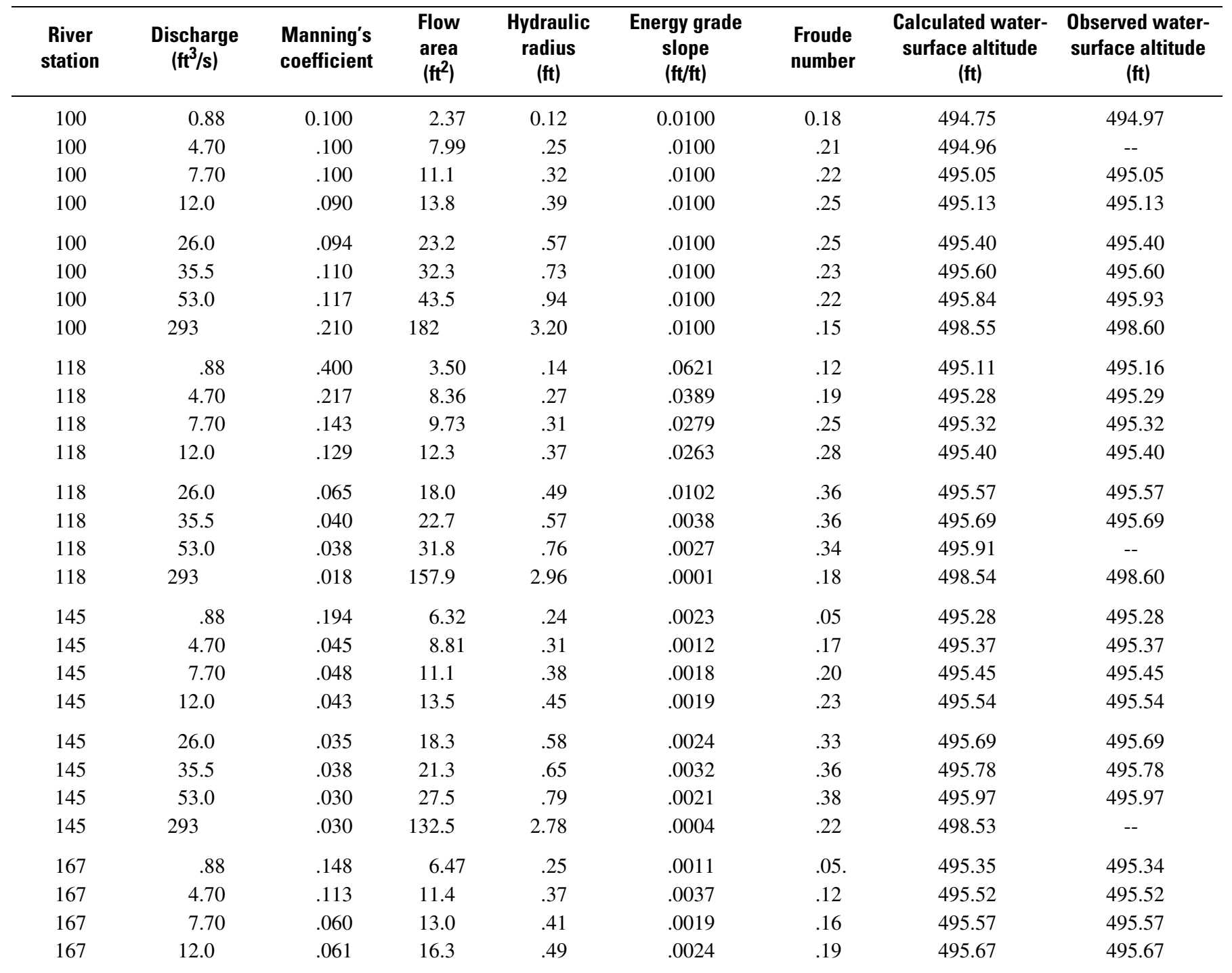


Table 3-9. Hydraulic variables simulated by HEC-RAS for the streamflows used for model calibration, Mount Hope River, CT.-Continued

\begin{tabular}{ccccccccc}
\hline $\begin{array}{c}\text { River } \\
\text { station }\end{array}$ & $\begin{array}{c}\text { Discharge } \\
\left.\mathbf{( f t}^{\mathbf{3}} \mathbf{/ s}\right)\end{array}$ & $\begin{array}{c}\text { Manning's } \\
\text { coefficient }\end{array}$ & $\begin{array}{c}\text { Flow } \\
\text { area } \\
\mathbf{f f t}^{\mathbf{2}} \text { ) }\end{array}$ & $\begin{array}{c}\text { Hydraulic } \\
\text { radius } \\
\mathbf{( f t )}\end{array}$ & $\begin{array}{c}\text { Energy grade } \\
\text { slope } \\
\text { (ft/ft) }\end{array}$ & $\begin{array}{c}\text { Froude } \\
\text { number }\end{array}$ & $\begin{array}{c}\text { Calculated water- } \\
\text { surface altitude } \\
\text { (ft) }\end{array}$ & $\begin{array}{c}\text { Observed water- } \\
\text { surface altitude } \\
\text { (ft) }\end{array}$ \\
\hline 167 & 26.0 & 0.086 & 23.3 & 0.66 & 0.0071 & 0.24 & 495.88 & 495.88 \\
167 & 35.5 & .112 & 27.4 & .76 & .0138 & .26 & 495.99 & 495.99 \\
167 & 53.0 & .190 & 36.9 & .97 & .0353 & .26 & 496.25 & 496.25 \\
167 & 293 & .130 & 133.8 & 2.92 & .0079 & .22 & 498.60 & 498.60 \\
192 & .88 & .128 & 4.48 & .19 & .0027 & .08 & 495.47 & 495.47 \\
192 & 4.70 & .080 & 8.41 & .32 & .0042 & .18 & 495.63 & 495.63 \\
192 & 7.70 & .079 & 10.2 & .33 & .0070 & .23 & 495.69 & 495.69 \\
192 & 12.0 & .065 & 12.7 & .37 & .0063 & .27 & 495.77 & 495.77 \\
192 & 26.0 & .045 & 21.0 & .56 & .0031 & .29 & 496.00 & 496.00 \\
192 & 35.5 & .030 & 25.4 & .66 & .0014 & .30 & 496.11 & 496.11 \\
192 & 53.0 & .030 & 36.9 & .90 & .0010 & .27 & 496.40 & 496.40 \\
192 & 293 & .020 & 132 & 2.79 & .0002 & .23 & 498.61 & 498.60 \\
\hline
\end{tabular}

Table 3-10. Hydraulic variables simulated by HEC-RAS for the streamflows meeting R2Cross criteria for determination of streamflows for habitat protection, Mount Hope River, CT.

$\left[\mathrm{ft}^{3} / \mathrm{s}\right.$, cubic foot per second; $\mathrm{ft}$, foot; $\mathrm{ft} / \mathrm{s}$, foot per second]

\begin{tabular}{|c|c|c|c|c|c|c|c|}
\hline $\begin{array}{l}\text { River } \\
\text { station }\end{array}$ & $\begin{array}{c}\text { Discharge } \\
\left(\mathrm{ft}^{3} / \mathrm{s}\right)\end{array}$ & $\begin{array}{l}\text { Top width } \\
\text { (ft) }\end{array}$ & $\begin{array}{c}\text { Wetted } \\
\text { perimeter } \\
\text { (ft) }\end{array}$ & $\begin{array}{c}\text { Average } \\
\text { velocity } \\
\text { (ft/s) }\end{array}$ & $\begin{array}{c}\text { Average } \\
\text { depth } \\
\text { (ft) }\end{array}$ & $\begin{array}{c}\text { Maximum } \\
\text { depth } \\
\text { (ft) }\end{array}$ & Notes \\
\hline 118 & 65.0 & 44.5 & 44.8 & 1.44 & 1.02 & 1.41 & Bankfull discharge. \\
\hline 118 & 19.0 & 34.1 & 34.2 & 1.25 & .45 & .67 & Meets 3-of-3 criteria. \\
\hline 118 & 12.6 & 33.0 & 33.1 & 1.00 & .39 & .59 & Meets 2 -of-3 criteria. \\
\hline 145 & 65.0 & 36.7 & 36.7 & 1.73 & 1.03 & 1.38 & Bankfull discharge. \\
\hline 145 & 14.7 & 30.4 & 30.5 & .70 & .38 & .59 & Meets 3-of-3 criteria. \\
\hline 145 & 7.00 & 29.0 & 29.1 & .66 & .37 & .57 & Meets 2-of-3 criteria. \\
\hline 167 & 65.0 & 39.3 & 39.6 & 1.47 & 1.12 & 1.54 & Bankfull discharge. \\
\hline 167 & 22.0 & 34.9 & 35.0 & 1.00 & .63 & .94 & Meets 3-of-3 criteria. \\
\hline 167 & 6.00 & 31.5 & 31.6 & .49 & .39 & .64 & Meets 2-of-3 criteria. \\
\hline 192 & 65.0 & 41.4 & 41.7 & 1.49 & 1.05 & 1.46 & Bankfull discharge. \\
\hline 192 & 15.0 & 35.5 & 35.6 & 1.00 & .42 & .73 & Meets 3-of-3 criteria. \\
\hline 192 & 14.5 & 35.3 & 35.4 & .99 & .41 & .72 & Meets 2 -of- 3 criteria. \\
\hline
\end{tabular}




\section{Little River near Hanover, CT (01123000)}

The study reach on the Little River River is just downstream of the Little River streamflow-gaging station (01121000) and about $500 \mathrm{ft}$ upstream of Hanover Road (fig. 3-6). The study reach begins at the head of a riffle that is downstream of the control for the streamflow-gaging station, and extends downstream about $200 \mathrm{ft}$ to the foot of the riffle adjacent to a mowed lawn on the right bank. The reach upstream and downstream of the study riffle includes riffle, run and pool habitat.

The drainage area to the site is about $30.0 \mathrm{mi}^{2}$. The study reach is within a moderate-gradient segment of the river that contains riffle, run, and pool habitat. The channel contains gravel, cobble, sand, and boulders. A few boulders along the left bank at the downstream end of the riffle exceed $5 \mathrm{ft}$ in width. Riparian vegetation is predominantly deciduous trees. The channel and immediate riparian area appears natural, although an old stone wall along the left bank and remnants of an old mill and canal downstream indicate there may have been some alterations historically. None of the alterations are recent.

The stream channel in the study reach is about 40 to $45 \mathrm{ft}$ wide. The channel has a moderate slope, and the water surface along the riffle drops about $0.90 \mathrm{ft}$ at $9 \mathrm{ft}^{3} / \mathrm{s}$, and $0.66 \mathrm{ft}$ at $34 \mathrm{ft}^{3} / \mathrm{s}$. Streambed substrate in the riffle is a mixture of gravel, cobble, and boulders, with minor amounts of sand. The bank material is is sand, soil, and boulders. The channel is mostly straight. The riffle cross sections are predominantly trapezoidal in shape and generally have a uniform cross section within the riffle except for irregularities created by scattered large boulders.

Four cross sections were surveyed along a $50 \mathrm{ft}$ length of the riffle. The most upstream cross section (station 162) and downstream cross (station 120) were near the breaks in slope at the upper and lower ends of the riffle. Reference points for measurement of water levels at different discharges were placed in the streambed at each cross section and in trees and along the right bank downstream of the riffle study reach.

A HEC-RAS model was used to calculate water-surface profiles. The model was run for a subcritical flow regime by use of the standard, upstream-step energy method. Input data for the model included cross section geometry, estimated roughness coefficients, and initial boundary conditions. All surveyed cross sections were included in the HEC-RAS model. A templated cross section was added between stations 133 and 140 .

For model calibration, water levels in the cross sections were measured at four different discharges, ranging from $9.0 \mathrm{ft}^{3} / \mathrm{s}$ to $34 \mathrm{ft}^{3} / \mathrm{s}$ (table 3.11 ). Initial roughness coefficients were determined for each cross section by back-calculation of Manning Equation at the calibration discharges. The calibration discharges were modeled at normal depth at the most downstream modeled section and a slope of $0.0035 \mathrm{ft} / \mathrm{ft}$ was input as a downstream boundary condition.

The discharges used for model calibration $(9.0,14.0,21.0$, and 34.0) were determined from stage-discharge ratings at the Little River streamflow-gaging station. The HEC-RAS model was calibrated by changing roughness coefficients for each cross section as required until calculated water-surface altitudes matched measured water-surface altitudes with reasonable accuracy. The calibration accuracy was $0.025 \mathrm{ft}$ over the entire reach for the measured discharges.

Indicators of the bankfull water line were identified in the field. Discharges that corresponded to the bankfull water line were determined from the calibrated model to be about $70 \mathrm{ft}^{3} / \mathrm{s}$.

The calibrated HEC-RAS model was used to produce a staging table of hydraulic parameters for 49 discharges between 9.0 and $34.0 \mathrm{ft}^{3} / \mathrm{s}$ for the cross sections at stations $120,133,140$, 153 , and 162 , respectively. The cross sections at stations 140 and 162 did not calibrate well, and were not used for determination of streamflow requirements by use of the R2Cross and Wetted Perimeter methods. The staging table was used to determine streamflow requirements by using R2Cross criteria (table 3.12).

The limiting R2Cross criterion or last of the three criteria to be met was the mean velocity for stations 133 and 120, and mean depth for cross section 154 . The second criterion to be met at each station was mean depth for stations 133 and 120, and mean velocity for station 154 . The average R2Cross streamflow requirement for the three cross sections, based on the streamflow that meets two of three hydraulic criteria, was $11.1 \mathrm{ft}^{3} / \mathrm{s}\left(0.37 \mathrm{ft}^{3} / \mathrm{s} / \mathrm{mi}^{2}\right)$. The average R2Cross streamflow requirement for the three cross sections, based on the streamflow that meets all three hydraulic criteria, was $28.7 \mathrm{ft}^{3} / \mathrm{s}$ $\left(0.96 \mathrm{ft}^{3} / \mathrm{s} / \mathrm{mi}^{2}\right)$.

A wetted-perimeter/discharge relation was determined for the cross sections at stations 154,133 , and 120 on the basis of the HEC-RAS model results. The average WettedPerimeter streamflow requirement for the three cross sections was $12.0 \mathrm{ft}^{3} / \mathrm{s}$ or $0.4 \mathrm{ft}^{3} / \mathrm{s} / \mathrm{mi}^{2}$. Breaks in the wettedperimeter/discharge relation that correspond to toe-of-bank elevations identified during site surveys were used to determine a Wetted-Perimeter streamflow requirement of about 10, 14, and $12 \mathrm{ft}^{3} / \mathrm{s}$ for cross sections stations 154, 133, and 120, respectively. For these stations, the maximum channel depths were about $0.58,0.96$, and $1.18 \mathrm{ft}$; the average mean water depths in the riffle were $0.29,0.53$, and $0.51 \mathrm{ft}$, the average mean velocities were $0.90,0.62$, and $0.64 \mathrm{ft} / \mathrm{s}$, and the average wetted perimeters were 85,92 , and 80 percent of the bankfull wetted perimeter, respectively. 


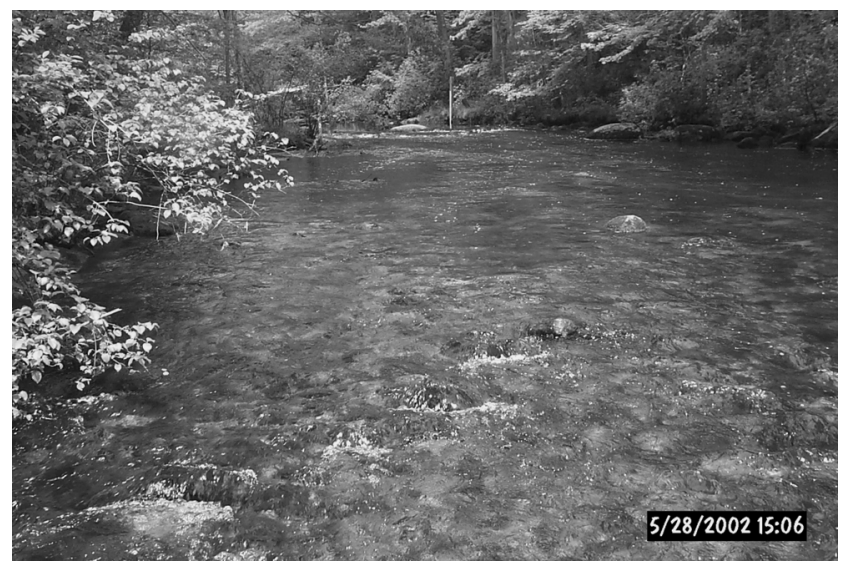

Figure 3-6. Riffle habitat on the Little River near Hanover, CT, upstream view.

Table 3-11. Hydraulic variables simulated by HEC-RAS for the streamflows used for model calibration, Little River, CT.

[River station: Numbers increase in an upstream direction. $\mathrm{ft}^{3} / \mathrm{s}$, cubic foot per second; $\mathrm{ft}$, foot; $\mathrm{ft} / \mathrm{ft}$, foot per foot; $\mathrm{ft}^{2}$, square foot; -, no data]

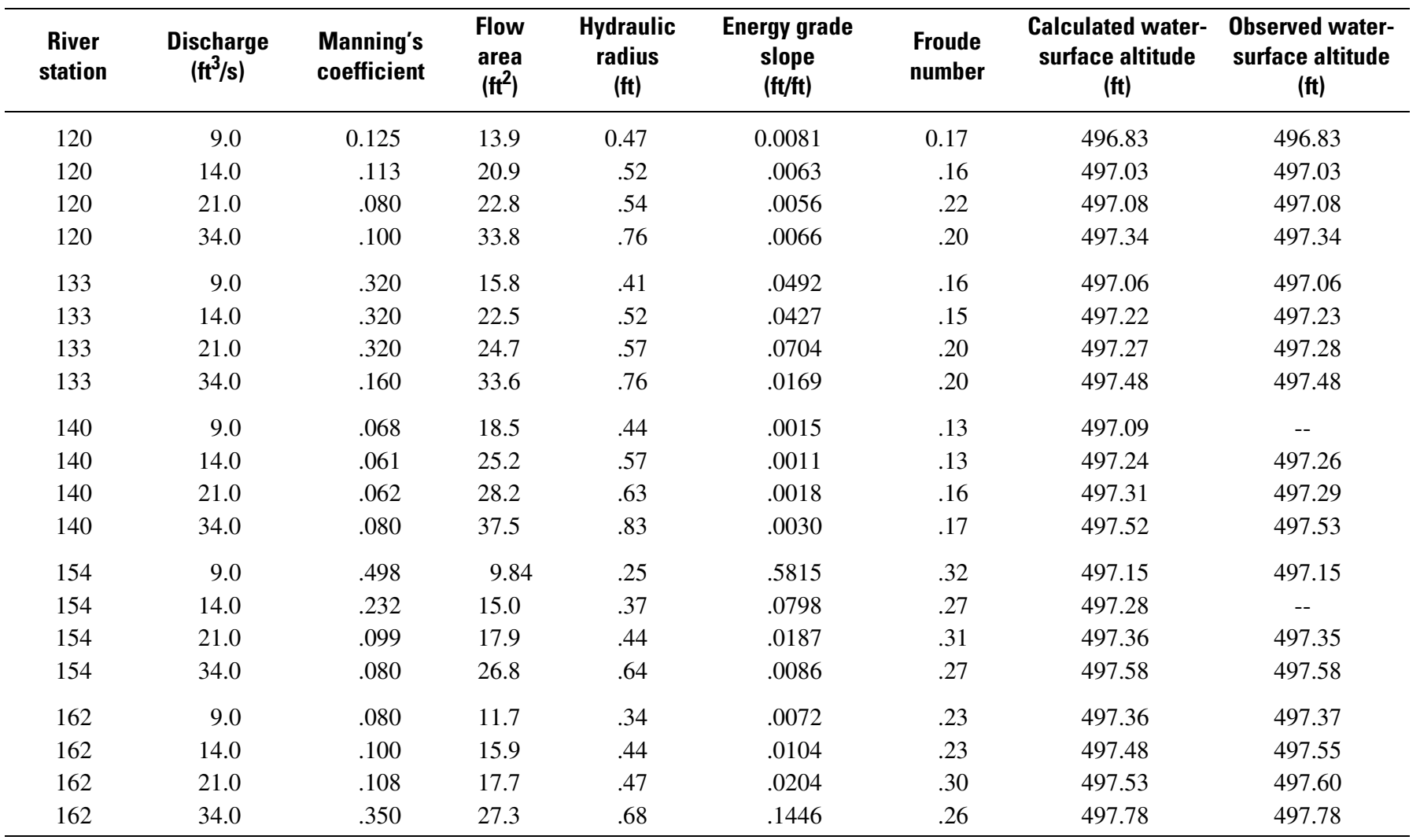


Table 3-12. Hydraulic variables simulated by HEC-RAS for the streamflows meeting R2Cross criteria for determination of streamflows for habitat protection, Little River, CT.

[ $\mathrm{ft}^{3} / \mathrm{s}$, cubic foot per second; $\mathrm{ft}$, foot; $\mathrm{ft} / \mathrm{s}$, foot per second]

\begin{tabular}{|c|c|c|c|c|c|c|c|}
\hline $\begin{array}{l}\text { River } \\
\text { station }\end{array}$ & $\begin{array}{c}\text { Discharge } \\
\left(\mathrm{ft}^{3} / \mathrm{s}\right)\end{array}$ & $\begin{array}{c}\text { Top width } \\
\text { (ft) }\end{array}$ & $\begin{array}{c}\text { Wetted } \\
\text { perimeter } \\
\text { (ft) }\end{array}$ & $\begin{array}{c}\text { Average } \\
\text { velocity } \\
\text { (ft/s) }\end{array}$ & $\begin{array}{l}\text { Average depth } \\
\text { (ft) }\end{array}$ & $\begin{array}{c}\text { Maximum } \\
\text { depth } \\
\text { (ft) }\end{array}$ & Notes \\
\hline 120 & 33.3 & 43.9 & 44.6 & 1.00 & .75 & 1.52 & Meets 3-of-3 criteria. \\
\hline 120 & 7.60 & 25.9 & 26.2 & .64 & .46 & .96 & Meets 2-of-3 criteria. \\
\hline 133 & 10.0 & 39.8 & 40.3 & .57 & .44 & .84 & Meets 2-of-3 criteria. \\
\hline 154 & 70.0 & 43.6 & 46.4 & 1.51 & 1.07 & 1.44 & Bankfull discharge. \\
\hline 154 & 20.0 & 39.8 & 40.9 & 1.16 & .43 & .73 & Meets 3-of-3 criteria. \\
\hline 154 & 15.75 & 39.4 & 40.4 & 1.00 & .39 & .68 & Meets 2 -of-3 criteria. \\
\hline
\end{tabular}

\section{South River near Conway, MA (01169900)}

The study reach on the South River is adjacent to the South River streamflow-gaging station (01169900) at the upstream side of Reeds Bridge just off Bardswell Ferry Road (fig. 3-7). The study reach begins at the head of a small riffle just upstream of the streamflow-gaging station, and extends downstream about $60 \mathrm{ft}$ to the foot of the riffle immediately upstream of the bridge. The reach upstream and downstream of the study riffle includes riffle, run and pool habitats.

The drainage area to the site is about $24.1 \mathrm{mi}^{2}$. The study reach is within a moderate gradient segment of the river that contains riffle, run, and pool habitat. Riparian vegetation is predominantly deciduous trees, with a few hemlocks along the right bank. The channel and immediate riparian area appears natural,

The stream channel in the study reach is about 35 to $45 \mathrm{ft}$ wide. The channel has a moderate slope, and the water surface along the riffle drops about $0.97 \mathrm{ft}$ at $2.7 \mathrm{ft}^{3} / \mathrm{s}$, and $1.0 \mathrm{ft}$ at $10 \mathrm{ft}^{3} / \mathrm{s}$. Streambed substrate in the riffle is a mixture of gravel, cobble, and boulders, with minor amounts of sand. The bank material is is sand, gravel, and soil. The channel is mostly straight. The riffle cross sections are predominantly trapezoidal in shape and generally have a uniform cross section.

Five cross sections were surveyed along a $60 \mathrm{ft}$ length of the riffle. The most upstream cross section (station 155) and downstream cross section (station 100) were near the breaks in slope at the upper and lower ends of the riffle. Reference points for measurement of water levels at different discharges were placed in the streambed at each cross section and in trees and along the right bank downstream of the riffle study reach.

A HEC-RAS model was used to calculate water-surface profiles. The model was run for a subcritical flow regime by use of the standard, upstream-step energy method. Input data for the model included cross section geometry, estimated roughness coefficients, and initial boundary conditions. All surveyed cross sections were included in the HEC-RAS model. Two templated cross-sections were added between stations 127 and 139, one between stations 139 and 146, and one between stations 146 and 155.

For model calibration, water levels in the cross sections were measured at four different discharges, ranging from $2.70 \mathrm{ft}^{3} / \mathrm{s}$ to $10 \mathrm{ft}^{3} / \mathrm{s}$ (table 3.13). Initial roughness coefficients were determined for each cross section by back-calculation of Manning Equation at the calibration discharges. The calibration discharges were modeled at normal depth at the most downstream modeled section and a slope of $0.0066 \mathrm{ft} / \mathrm{ft}$ was input as a downstream boundary condition.

The discharges used for model calibration $(2.70,4.10$, 6.00 , and 10.0) were determined from stage-discharge ratings at the Little River streamflow-gaging station. The HEC-RAS model was calibrated by changing roughness coefficients for each cross section as required until calculated water-surface altitudes matched measured water-surface altitudes with reasonable accuracy. The calibration accuracy was $0.0032 \mathrm{ft}$ over the entire reach for the measured discharges. 


\section{Streamflow Requirements and Streamflow Characteristics at Index Stations in Southern New England}

Indicators of the bankfull water line were identified in the field. Discharges that corresponded to the bankfull water line were determined from the calibrated model to be about $120 \mathrm{ft}^{3} / \mathrm{s}$.

The calibrated HEC-RAS model was used to produce a staging table of hydraulic parameters for 49 discharges between 1 and $200 \mathrm{ft}^{3} / \mathrm{s}$ for cross sections at stations 100, 127, 139, 146, and 155. Cross sections at stations 127, 139, 146, and 155 were used for determination of streamflow requirements by use of the R2Cross and Wetted Perimeter methods. The staging table was used to determine streamflow requirements using R2Cross criteria (table 3.14).

The limiting R2Cross criterion or last of the three criteria to be met was the mean velocity for stations 146 and 127, and mean depth for station 139. The second criterion to be met at each station was mean depth for stations 146 and 127, and mean velocity for station 139 . The average R2Cross streamflow requirement for the three cross sections, based on the streamflow that meets 2-of-3 hydraulic criteria, was $17.3 \mathrm{ft}^{3} / \mathrm{s}$ $\left(0.72 \mathrm{ft}^{3} / \mathrm{s} / \mathrm{mi}^{2}\right)$. The average $\mathrm{R} 2 \mathrm{Cross}$ streamflow requirement for the three cross sections, based on the streamflow that meets all three hydraulic criteria, was $22.3 \mathrm{ft}^{3} / \mathrm{s}\left(0.92 \mathrm{ft}^{3} / \mathrm{s} / \mathrm{mi}^{2}\right)$.

A wetted-perimeter/discharge relation was determined for the cross sections at stations 127, 139, and 146 on the basis of the HEC-RAS model results. The average WettedPerimeter streamflow requirement for the three cross sections was $6.67 \mathrm{ft}^{3} / \mathrm{s}$ or $0.28 \mathrm{ft}^{3} / \mathrm{s} / \mathrm{mi}^{2}$. Breaks in the wettedperimeter/discharge relation that correspond to toe-of-bank elevations identified during site surveys were used to determine a Wetted-Perimeter streamflow requirement of about 5.5, 7.5, and $7.0 \mathrm{ft}^{3} / \mathrm{s}$ for the cross sections at stations 127,139 , and 146 , respectively. For these stations, the maximum channel depths were about $0.66,0.47$, and $0.50 \mathrm{ft}$; the average mean water depths in the riffle were $0.32,0.23$, and $0.27 \mathrm{ft}$, the average mean velocities were $0.49,0.80$, and $0.61 \mathrm{ft} / \mathrm{s}$, and the average wetted perimeters were 78,85 , and 83 percent of the bankfull wetted perimeter, respectively.

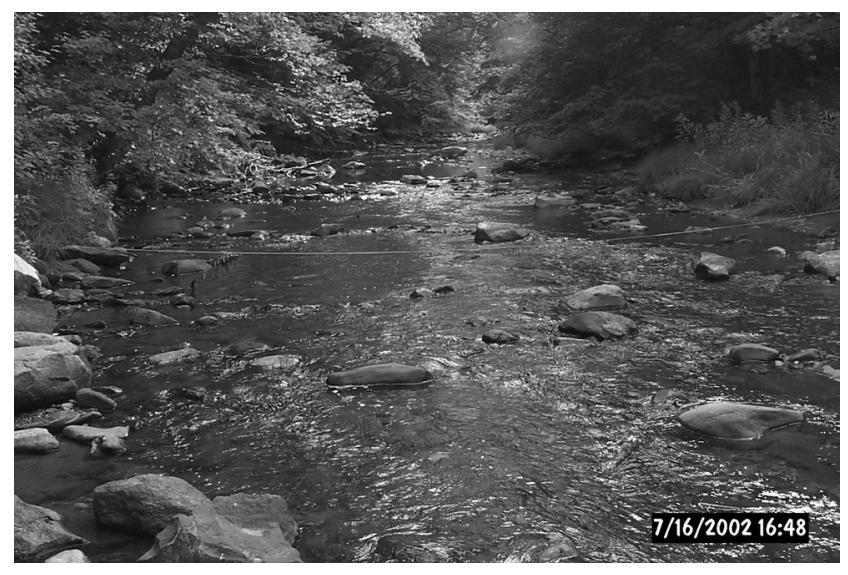

Figure 3-7. Riffle habitat on the South River near Conway, MA, upstream view. 
Table 3-13. Hydraulic variables simulated by HEC-RAS for the streamflows used for model calibration, South River, MA.

[River station: Numbers increase in an upstream direction. $\mathrm{ft}^{3} / \mathrm{s}$, cubic foot per second; $\mathrm{ft}$, foot; $\mathrm{ft} / \mathrm{ft}$, foot per foot; $\mathrm{ft}^{2}$, square foot; -, no data]

\begin{tabular}{|c|c|c|c|c|c|c|c|c|}
\hline $\begin{array}{l}\text { River } \\
\text { station }\end{array}$ & $\begin{array}{c}\text { Discharge } \\
\left(\mathrm{ft}^{3} / \mathrm{s}\right)\end{array}$ & $\begin{array}{l}\text { Manning's } \\
\text { coefficient }\end{array}$ & $\begin{array}{l}\text { Flow } \\
\text { area } \\
\left(\mathrm{ft}^{2}\right)\end{array}$ & $\begin{array}{l}\text { Hydraulic } \\
\text { radius } \\
\text { (ft) }\end{array}$ & $\begin{array}{l}\text { Energy grade } \\
\text { slope } \\
\text { (ft/ft) }\end{array}$ & $\begin{array}{l}\text { Froude } \\
\text { number }\end{array}$ & $\begin{array}{l}\text { Calculated water- } \\
\text { surface altitude } \\
\text { (ft) }\end{array}$ & $\begin{array}{l}\text { Observed water- } \\
\text { surface altitude } \\
\text { (ft) }\end{array}$ \\
\hline 100 & 2.70 & 0.037 & 2.80 & 0.16 & 0.0066 & 0.42 & 494.04 & 494.04 \\
\hline 100 & 4.10 & .039 & 3.99 & .19 & .0066 & .41 & 494.10 & -- \\
\hline 100 & 6.00 & .041 & 5.28 & .24 & .0066 & .41 & 494.16 & 494.16 \\
\hline 100 & 10.0 & .038 & 7.05 & .30 & .0066 & .46 & 494.24 & 494.24 \\
\hline 127 & 2.70 & .370 & 8.02 & .27 & .0400 & .11 & 494.43 & 494.43 \\
\hline 127 & 4.10 & .355 & 10.4 & .30 & .0444 & .13 & 494.50 & 494.50 \\
\hline 127 & 6.00 & 190 & 11.5 & .32 & .0202 & .16 & 494.53 & 494.53 \\
\hline 127 & 10.0 & .185 & 14.6 & .40 & .0248 & .19 & 494.62 & 494.62 \\
\hline 139 & 2.70 & .040 & 4.82 & .15 & .0028 & .25 & 494.51 & 494.51 \\
\hline 139 & 4.10 & .037 & 6.67 & .19 & .0022 & .25 & 494.57 & 494.57 \\
\hline 139 & 6.00 & .035 & 7.79 & .21 & .0027 & .30 & 494.60 & 494.60 \\
\hline 139 & 10.0 & .040 & 11.7 & .28 & .0029 & .28 & 494.70 & 494.69 \\
\hline 146 & 2.70 & .100 & 5.98 & .17 & .0096 & .19 & 494.68 & 494.68 \\
\hline 146 & 4.10 & .121 & 8.62 & .21 & .0118 & .18 & 494.75 & 494.74 \\
\hline 146 & 6.00 & .123 & 10.6 & .26 & .0136 & .20 & 494.79 & 494.79 \\
\hline 146 & 10.0 & .100 & 13.8 & .32 & .0108 & .22 & 494.87 & 494.87 \\
\hline 155 & 2.70 & .744 & 15.2 & .42 & .0252 & .05 & 495.01 & 495.01 \\
\hline 155 & 4.10 & .624 & 17.8 & .48 & .0252 & .06 & 495.08 & 495.08 \\
\hline 155 & 6.00 & .503 & 19.9 & .52 & .0248 & .07 & 495.14 & 495.14 \\
\hline 155 & 10.0 & .430 & 25.3 & .60 & .0280 & .09 & 495.25 & 495.25 \\
\hline
\end{tabular}

Table 3-14. Hydraulic variables simulated by HEC-RAS for the streamflows meeting R2Cross criteria for determination of streamflows for habitat protection, South River, MA.

$\left[\mathrm{ft}^{3} / \mathrm{s}\right.$, cubic foot per second; $\mathrm{ft}$, foot; $\mathrm{ft} / \mathrm{s}$, foot per second]

\begin{tabular}{|c|c|c|c|c|c|c|c|}
\hline $\begin{array}{l}\text { River } \\
\text { station }\end{array}$ & $\begin{array}{c}\text { Discharge } \\
\quad\left(\mathrm{ft}^{3} / \mathrm{s}\right)\end{array}$ & $\begin{array}{c}\text { Top width } \\
\text { (ft) }\end{array}$ & $\begin{array}{c}\text { Wetted } \\
\text { perimeter } \\
\text { (ft) }\end{array}$ & $\begin{array}{c}\text { Average } \\
\text { velocity } \\
\text { (ft/s) }\end{array}$ & $\begin{array}{c}\text { Average } \\
\text { depth } \\
\text { (ft) }\end{array}$ & $\begin{array}{c}\text { Maximum } \\
\text { depth } \\
\text { (ft) }\end{array}$ & Notes \\
\hline 127 & 23.5 & 38.1 & 38.3 & 1.00 & .62 & 1.00 & Meets 3-of-3 criteria. \\
\hline 127 & 13.0 & 36.7 & 36.9 & .77 & .46 & .82 & Meets 2-of-3 criteria. \\
\hline 139 & 18.0 & 42.2 & 42.3 & 1.00 & .42 & .68 & Meets 2-of-3 criteria. \\
\hline 146 & 120 & 49.7 & 50.9 & 1.92 & 1.26 & 1.64 & Bankfull discharge. \\
\hline 146 & 22.0 & 43.0 & 43.4 & 1.00 & .51 & .74 & Meets 3-of-3 criteria. \\
\hline 146 & 21.0 & 42.9 & 43.3 & .96 & .50 & .71 & Meets 2 -of-3 criteria. \\
\hline
\end{tabular}




\section{Green River near Colrain, MA (01170100)}

The study reach on the Green River is downstream of the Green River streamflow-gaging station (01170100) (fig. 3-8). The study reach begins about $100 \mathrm{ft}$ downstream of the streamflow-gaging station. The upper end of the reach begins in a run upstream of a riffle, adjacent to where a very small unnamed tributary enters from the right bank. The reach extends about $150 \mathrm{ft}$ downstream to the foot of the riffle, where there is a bedrock outcrop on the right bank. The reach upstream and downstream of the study riffle includes riffle, run and pool habitats.

The drainage area to the site is about $41.4 \mathrm{mi}^{2}$. The study reach is within a moderate gradient segment of the river that contains riffle, run, and pool habitat. Riparian vegetation is predominantly deciduous trees. Bedrock exposures in the right bank upstream and downstream of the study reach indicate a shallow depth to bedrock beneath the channel. The channel and immediate riparian area appear unaltered.

The stream channel in the study reach is about 70 to $90 \mathrm{ft}$ wide. The channel has a moderate slope, and the water surface along the riffle drops about $1.47 \mathrm{ft}$ at $7.0 \mathrm{ft}^{3} / \mathrm{s}$, and $1.30 \mathrm{ft}$ at $69.6 \mathrm{ft}^{3} / \mathrm{s}$. Streambed substrate in the riffle is a mixture of gravel, cobble, and boulders. The bank material is is gravel, boulders, and soil. The channel is mostly straight. The riffle cross sections are predominantly trapezoidal in shape and generally have a uniform cross section.

Four cross sections were surveyed along a $60 \mathrm{ft}$ length of the riffle. The cross sections at stations 285 and 200 were near the breaks in slope at the upper and lower ends of the riffle, respectively. Reference points for measurement of water levels at different discharges were placed in the streambed at each cross section and in the streambed downstream of the riffle study reach.

A HEC-RAS model was used to calculate water-surface profiles. The model was run for a subcritical flow regime by use of the standard, upstream-step energy method. Input data for the model included cross-section geometry, estimated roughness coefficients, and initial boundary conditions. All surveyed cross sections were included in the HEC-RAS model. A templated cross section was added between sections 200 and 234, and two templated cross sections were added between sections 234 and 285.

For model calibration, water levels in the cross sections were measured at five different discharges, ranging from $7.00 \mathrm{ft}^{3} / \mathrm{s}$ to $69.6 \mathrm{ft}^{3} / \mathrm{s}$ (table 3.15). Initial roughness coefficients were determined for each cross section by back-calculation of Manning Equation at the calibration discharges. The calibration discharges were modeled at normal depth at the most downstream modeled section and a slope of $0.0008 \mathrm{ft} / \mathrm{ft}$ was input as a downstream boundary condition.

The discharges used for model calibration $(7.00,8.70$, $12.0,25.0$, and $69.6 \mathrm{ft}^{3} / \mathrm{s}$ ) were determined from stagedischarge ratings at the Little River streamflow-gaging station. The HEC-RAS model was calibrated by changing roughness coefficients for each cross section as required until calculated water-surface altitudes matched measured water-surface altitudes with reasonable accuracy. The calibration accuracy was $0.0 \mathrm{ft}$ over the entire reach for the measured discharges.

Indicators of the bankfull water line were identified in the field. Discharges that corresponded to the bankfull water line were determined from the calibrated model to be about $220 \mathrm{ft}^{3} / \mathrm{s}$.

The calibrated HEC-RAS model was used to produce a staging table of hydraulic parameters for 80 discharges between 1 and $400 \mathrm{ft}^{3} / \mathrm{s}$ for the cross sections at stations $200,234,285$, and 341 . The cross sections at stations 234 and 285 were used for determination of streamflow requirements by use of the R2Cross and Wetted Perimeter methods. The staging table was used to determine streamflow requirements using R2Cross criteria (table 3.16).

The limiting R2Cross criterion or last of the three criterion to be met was the mean depth for the cross section at station 285 , and mean velocity for the cross section at station 234 . The second criterion to be met at each station was mean velocity for station 285, and mean depth for station 234. The average R2Cross streamflow requirement for the two cross sections, based on the streamflow that meets 2-of-3 hydraulic criteria, was $35.0 \mathrm{ft}^{3} / \mathrm{s}\left(0.85 \mathrm{ft}^{3} / \mathrm{s} / \mathrm{mi}^{2}\right)$. The average R2Cross streamflow requirement for the two cross sections, based on the streamflow that meets all three hydraulic criteria, was $88.5 \mathrm{ft}^{3} / \mathrm{s}$ $\left(2.14 \mathrm{ft}^{3} / \mathrm{s} / \mathrm{mi}^{2}\right)$.

A wetted-perimeter/discharge relation was determined for the cross sections at stations 234 and 285 on the basis of the HEC-RAS model results. The average Wetted-Perimeter streamflow requirement for the two cross sections was $24.0 \mathrm{ft}^{3} / \mathrm{s}$ or $0.58 \mathrm{ft}^{3} / \mathrm{s} / \mathrm{mi}^{2}$. Breaks in the wetted-perimeter/discharge relation that correspond to toe-of-bank elevations identified during site surveys were used to determine a Wetted-Perimeter streamflow requirement of about 16 and $32 \mathrm{ft}^{3} / \mathrm{s}$ for the cross sections at stations 234 and 285, respectively. For these stations, the maximum channel were about 1.1, and $0.73 \mathrm{ft}$; the average mean water depths in the riffle were 0.50 and $0.46 \mathrm{ft}$, the average mean velocities were 0.52 and $0.94 \mathrm{ft} / \mathrm{s}$, and the average wetted perimeters were 84 and 84 percent of the bankfull wetted perimeter, respectively. 


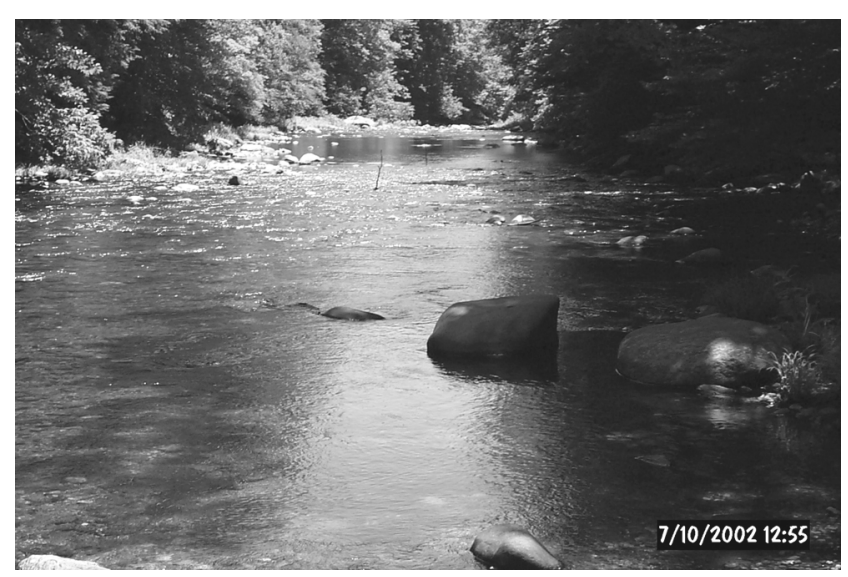

Figure 3-8. Riffle habitat on the Green River near Colrain, MA, downstream view.

Table 3-15. Hydraulic variables simulated by HEC-RAS for the streamflows used for model calibration, Green River near Colrain, MA.

[River station: Numbers increase in an upstream direction. $\mathrm{ft}^{3} / \mathrm{s}$, cubic foot per second; $\mathrm{ft}$, foot; $\mathrm{ft} / \mathrm{ft}$, foot per foot; $\mathrm{ft}^{2}$, square foot; -, no data]

\begin{tabular}{|c|c|c|c|c|c|c|c|c|}
\hline $\begin{array}{c}\text { River } \\
\text { station }\end{array}$ & $\begin{array}{c}\text { Discharge } \\
\left(\mathrm{ft}^{3} / \mathrm{s}\right)\end{array}$ & $\begin{array}{l}\text { Manning's } \\
\text { coefficient }\end{array}$ & $\begin{array}{c}\text { Flow } \\
\text { area } \\
\left(\mathrm{ft}^{2}\right)\end{array}$ & $\begin{array}{l}\text { Hydraulic } \\
\text { radius } \\
\text { (ft) }\end{array}$ & $\begin{array}{l}\text { Energy grade } \\
\text { slope } \\
\text { (ft/ft) }\end{array}$ & $\begin{array}{l}\text { Froude } \\
\text { number }\end{array}$ & $\begin{array}{l}\text { Calculated water- } \\
\text { surface altitude } \\
\text { (ft) }\end{array}$ & $\begin{array}{l}\text { Observed water- } \\
\text { surface altitude } \\
\text { (ft) }\end{array}$ \\
\hline 200 & 8.70 & .109 & 28.7 & .69 & .0008 & .06 & 493.77 & 493.77 \\
\hline 200 & 12.0 & .085 & 30.4 & .71 & .0008 & .08 & 493.81 & 493.81 \\
\hline 200 & 25.0 & .056 & 39.5 & .77 & .0008 & .13 & 494.00 & 494.00 \\
\hline 234 & 7.00 & .220 & 20.3 & .46 & .0073 & .09 & 493.78 & 493.78 \\
\hline 234 & 8.70 & .172 & 23.0 & .51 & .0047 & .09 & 493.84 & 493.84 \\
\hline 234 & 12.0 & .081 & 24.8 & .48 & .0018 & .12 & 493.87 & 493.87 \\
\hline 234 & 25.0 & .129 & 39.6 & .64 & .0055 & .14 & 494.13 & 494.13 \\
\hline 234 & 69.9 & .036 & 55.4 & .87 & .0011 & .24 & 494.38 & 494.38 \\
\hline 285 & 25.0 & .147 & 30.6 & .41 & .0212 & .22 & 494.93 & 494.93 \\
\hline 285 & 69.9 & .090 & 48.2 & .60 & .0151 & .33 & 495.16 & 495.16 \\
\hline 341 & 7.00 & .110 & 21.4 & .30 & .0030 & .11 & 495.18 & 495.18 \\
\hline 341 & 8.70 & .118 & 24.8 & .34 & .0033 & .11 & 495.23 & 495.23 \\
\hline 341 & 12.0 & .085 & 25.7 & .35 & .0029 & .14 & 495.24 & 495.24 \\
\hline 341 & 25.0 & .085 & 36.3 & .48 & .0041 & .17 & 495.38 & 495.38 \\
\hline 341 & 69.9 & .060 & 53.2 & .68 & .0047 & .28 & 495.60 & 495.60 \\
\hline
\end{tabular}


Table 3-16. Hydraulic variables simulated by HEC-RAS for the streamflows meeting R2Cross criteria for determination of streamflows for habitat protection Green River near Colrain.

$\left[\mathrm{ft}^{3} / \mathrm{s}\right.$, cubic foot per second; $\mathrm{ft}$, foot; ft/s, foot per second]

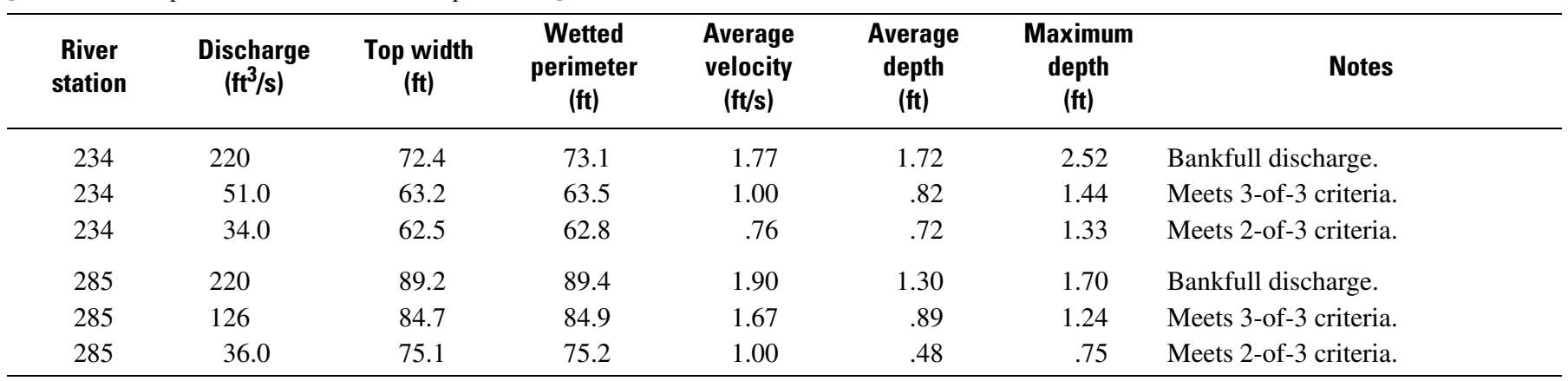

\section{Sevenmile River near Spencer, MA (01175670)}

The study reach on the Green River is downstream of the Sevenmile streamflow-gaging station (01175670) (fig. 3-9). The study reach begins about $150 \mathrm{ft}$ downstream of the bridge on Cooney Road. The study reach is about $100 \mathrm{ft}$ in length and includes a riffle and pool sequence. The upper end of the reach begins at the head of the upper riffle, where the river begins to bend to the left, and extends downstream through the riffle and a deep pool. The study reach ends at the upper end of the lower riffle where the river meanders to the right. The reach upstream and downstream of the study riffle is run and pool habitat.

The drainage area to the site is about $8.81 \mathrm{mi}^{2}$ (revised from a previously published value of $8.68 \mathrm{mi}^{2}$, P.J. Zarriello, U.S. Geological Survey, written commun., 2003). The study reach is within a moderate gradient segment of the river that contains riffle, run, and pool habitat. Riparian vegetation is predominantly shrubs and deciduous trees. The channel has been altered upstream of the study reach adjacent to the road, and there are remnants of an old dam upstream of the streamflow-gaging station. However, the channel and riparian area in the study reach appear unaltered.

The stream channel in the study reach is about 15 to $20 \mathrm{ft}$ wide. The channel has a moderate slope, and the water surface along the riffle drops about $0.94 \mathrm{ft}$ at $0.06 \mathrm{ft}^{3} / \mathrm{s}$, and $1.15 \mathrm{ft}$ at $54.0 \mathrm{ft}^{3} / \mathrm{s}$. Streambed substrate in the riffle is a mixture of gravel, cobbles, boulders, and sand. The bank material is is gravel, and soil. The channel is mostly straight through the upper riffle, but meanders in the lower reaches. The riffle cross sections are predominantly trapezoidal in shape and generally have a uniform cross section. The pool is deeper along the outside of the bend.

Five cross sections were surveyed along a $60 \mathrm{ft}$ length of the riffle. The cross sections at stations 195 and 165 were near the breaks in slope at the upper and lower ends of the riffle, respectively. Reference points for measurement of water levels at different discharges were placed in the streambed at each cross section and in the streambed downstream of the riffle study reach.
A HEC-RAS model was used to calculate water-surface profiles. The model was run for a subcritical flow regime by use of the standard, upstream-step energy method. Input data for the model included cross-section geometry, estimated roughness coefficients, and initial boundary conditions. All cross sections were included in the HEC-RAS model. A templated cross section was added between each of the cross sections.

For model calibration, water levels in the cross sections were measured at five different discharges, ranging from $0.06 \mathrm{ft}^{3} / \mathrm{s}$ to $54.0 \mathrm{ft}^{3} / \mathrm{s}$ (table 3.17 ). Initial roughness coefficients were determined for each cross section by back-calculation of Manning Equation at the calibration discharges. The calibration discharges were modeled at normal depth at the most downstream modeled section and a slope of $0.0032 \mathrm{ft} / \mathrm{ft}$ was input as a downstream boundary condition.

The discharges used for model calibration $(0.06,1.70$, $11.0,19.0$, and $54.0 \mathrm{ft}^{3} / \mathrm{s}$ ) were determined from stagedischarge ratings at the Sevenmile River streamflow-gaging station. The HEC-RAS model was calibrated by changing roughness coefficients for each cross section as required until calculated water-surface altitudes matched measured watersurface altitudes with reasonable accuracy. The calibration accuracy was $0.016 \mathrm{ft}$ over the entire reach for the measured discharges.

Indicators of the bankfull water line were identified in the field. Discharges that corresponded to the bankfull water line were determined from the calibrated model to be about $35 \mathrm{ft}^{3} / \mathrm{s}$.

The calibrated HEC-RAS model was used to produce a staging table of hydraulic parameters for 64 discharges between 1 and $60 \mathrm{ft}^{3} / \mathrm{s}$ for the cross sections at stations $100,149,165$, 180, and 195. The cross section at stations 165, 180, and 195 were used for determination of streamflow requirements by use of the R2Cross and Wetted Perimeter methods. The staging table was used to determine streamflow requirements using R2Cross criteria (table 3.18).

The limiting R2Cross criterion or last of the three criteria to be met was the mean velocity for the cross sections at stations 195 and 180, and mean depth for the cross section at station 165 . The second criterion to be met was percent of bankfull wetted 
perimeter for the cross sections at stations 195 and 165, and mean depth for the cross section at station 180. The average R2Cross streamflow requirement for the three cross sections, based on the streamflow that meets two of three hydraulic criteria, was $3.43 \mathrm{ft}^{3} / \mathrm{s}\left(0.39 \mathrm{ft}^{3} / \mathrm{s} / \mathrm{mi}^{2}\right)$. The average R2Cross streamflow requirement for the three cross sections, based on the streamflow that meets all three hydraulic criteria, was $1.4 \mathrm{ft}^{3} / \mathrm{s}\left(0.16 \mathrm{ft}^{3} / \mathrm{s} / \mathrm{mi}^{2}\right)$.

A wetted-perimeter/discharge relation was determined for the cross sections at stations 165,180 , and 195 on the basis of the HEC-RAS model results. The average Wetted-Perimeter streamflow requirement for the three cross sections was $3.4 \mathrm{ft}^{3} / \mathrm{s}$ or $0.39 \mathrm{ft}^{3} / \mathrm{s} / \mathrm{mi}^{2}$. Breaks in the wetted-perimeter/discharge relation that correspond to toe-of-bank elevations identified during site surveys were used to determine a Wetted-Perimeter streamflow requirement of about 4.0, 1.2, and 5.0 for the cross sections at stations 165,180 , and 195, respectively. For these stations, the maximum channel depths were about $0.62,1.19 \mathrm{ft}$, and 0.46 ; the average mean water depths in the riffle were 0.31 , $0.19 \mathrm{ft}$, and 0.22 the average mean velocities were $1.21,0.53$, and $1.33 \mathrm{ft} / \mathrm{s}$, and the average wetted perimeters were 71,66 , and 78 percent of the bankfull wetted perimeter, respectively.

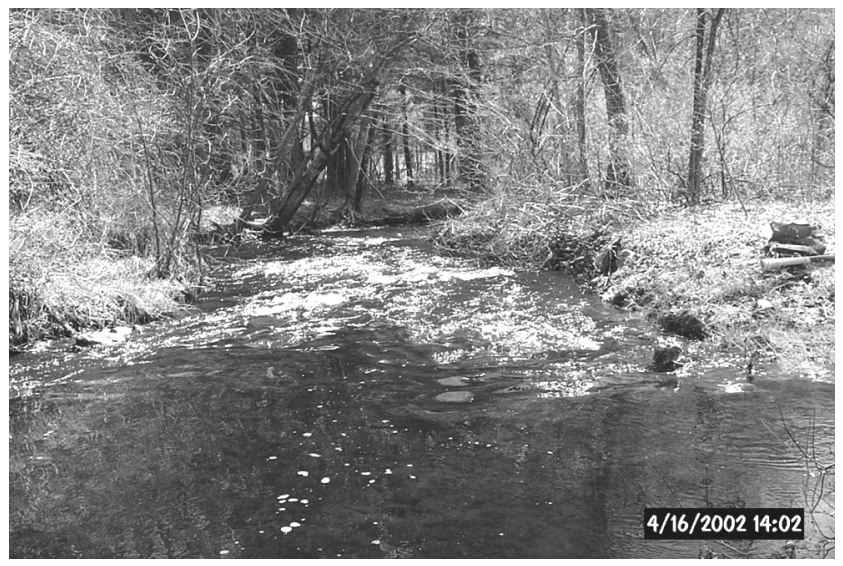

Figure 3-9. Riffle habitat in the Sevenmile River, MA downstream view. 
98 Streamflow Requirements and Streamflow Characteristics at Index Stations in Southern New England

Table 3-17. Hydraulic variables simulated by HEC-RAS for the streamflows used for model calibration, Sevenmile River, MA.

[River station: Numbers increase in an upstream direction. $\mathrm{ft}^{3} / \mathrm{s}$, cubic foot per second; $\mathrm{ft}$, foot; $\mathrm{ft} / \mathrm{ft}$, foot per foot; $\mathrm{ft}^{2}$, square foot; -, no data]

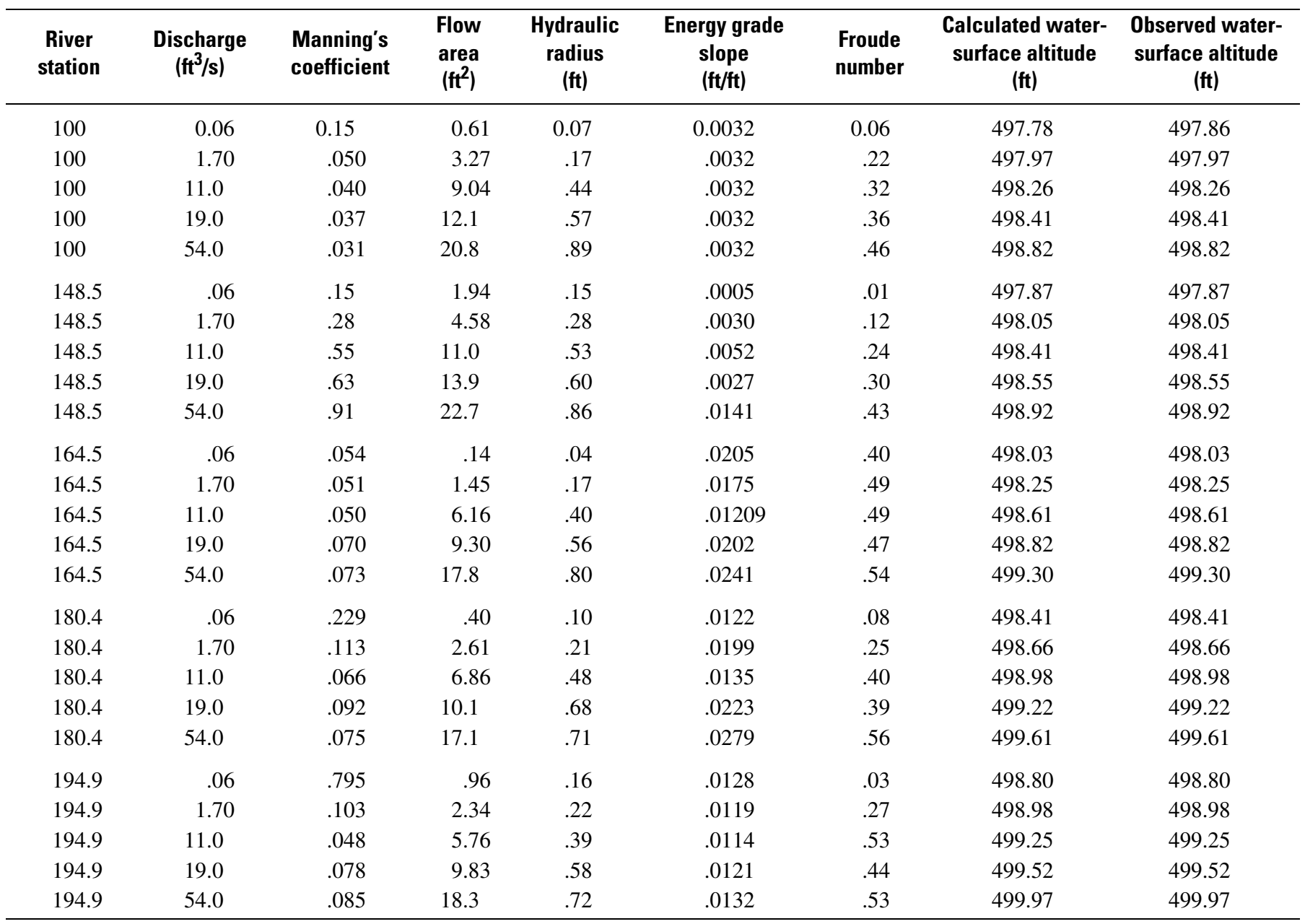

Table 3-18. Hydraulic variables simulated by HEC-RAS for the streamflows meeting R2Cross criteria for determination of streamflows for habitat protection Sevenmile River, MA.

$\left[\mathrm{ft}^{3} / \mathrm{s}\right.$, cubic foot per second; $\mathrm{ft}$, foot; ft/s, foot per second]

\begin{tabular}{|c|c|c|c|c|c|c|c|}
\hline $\begin{array}{l}\text { River } \\
\text { station }\end{array}$ & $\begin{array}{c}\text { Discharge } \\
\left(\mathrm{ft}^{3} / \mathrm{s}\right)\end{array}$ & $\begin{array}{c}\text { Top width } \\
\text { (ft) }\end{array}$ & $\begin{array}{c}\text { Wetted } \\
\text { perimeter } \\
\text { (ft) }\end{array}$ & $\begin{array}{c}\text { Average } \\
\text { velocity } \\
\text { (ft/s) }\end{array}$ & $\begin{array}{c}\text { Average } \\
\text { depth } \\
\text { (ft) }\end{array}$ & $\begin{array}{c}\text { Maximum } \\
\text { depth } \\
\text { (ft) }\end{array}$ & Notes \\
\hline 165 & 2.50 & 9.73 & 9.99 & 1.26 & .20 & .37 & Meets 3-of-3 criteria. \\
\hline 165 & 2.25 & 9.12 & 9.37 & 1.25 & .20 & .36 & Meets 2 -of-3 criteria. \\
\hline 180 & 1.40 & 12.2 & 12.4 & .58 & .20 & .41 & Meets 2-of-3 criteria. \\
\hline 195 & 35.0 & 18.2 & 19.2 & 2.50 & .77 & 1.26 & Bankfull discharge. \\
\hline 195 & 3.50 & 12.1 & 12.5 & 1.00 & .29 & .57 & Meets 3-of-3 criteria. \\
\hline 195 & .55 & 9.35 & 9.61 & .28 & .21 & 1.44 & Meets 2 -of-3 criteria. \\
\hline
\end{tabular}




\section{Green River at Williamstown, MA (01333000)}

The study reach on the Green River is upstream of the Green River streamflow-gaging station (01333000) (fig. 3-10). The study reach begins at the bedrock control adjacent to the streamflow-gaging station and extends upstream about $150 \mathrm{ft}$. The upper end of the reach begins at the head of a riffle, and extends downstream to a bedrock control that is adjacent to the streamflow-gaging station on the left bank and an access path under an old stone dam structure on the right bank. The reach upstream of the study riffle is run and pool habitat. Immediately downstream of the study reach the river passes over a bedrock falls.

The drainage area to the site is about $42.6 \mathrm{mi}^{2}$. The study reach is within a moderate-gradient segment of the river that contains riffle, run, and pool habitats. Riparian vegetation is predominantly deciduous trees. There are several alterations to the river in the vicinity of the study reach. The left and right banks contain the remnants of an old stone dam that would have impounded the riffle when it was in existence. Upstream of the riffle on the left bank there is a large pile of boulders that is human-made. Scattered pieces of metal debris and brick are imbedded into the streambed. None of these alterations appear recent, however, and do not appear to appreciably alter the present form of the channel or riparian area within the study reach.

The stream channel in the study reach is about 50 to $60 \mathrm{ft}$ wide. The channel has a moderate slope, and the water surface along the riffle drops about $1.13 \mathrm{ft}$ at $6.90 \mathrm{ft}^{3} / \mathrm{s}$, and $1.04 \mathrm{ft}$ at $122 \mathrm{ft}^{3} / \mathrm{s}$. Streambed substrate in the riffle is a mixture of gravel, cobbles, boulders, and sand. The bank material is is sand, gravel, and soil. The channel bends slightly to the left through the riffle. At the lower end of the reach the thalweg moves to the left to get around a bedrock obstruction in the channel. The riffle cross sections are predominantly trapezoidal in shape, and, except for a few scattered large boulders, generally have uniform cross sections.

Four cross sections were surveyed along a $150 \mathrm{ft}$ length of the riffle. The cross sections at stations 244 and 100 were near the breaks in slope at the upper and lower ends of the riffle, respectively. Reference points for measurement of water levels at different discharges were placed in the streambed at each cross section and in the tree roots along the left and right banks.

A HEC-RAS model was used to calculate water-surface profiles. The model was run for a subcritical flow regime by use of the standard, upstream-step energy method. Input data for the model included cross section geometry, estimated roughness coefficients, and initial boundary conditions. All cross sections were included in the HEC-RAS model. A templated crosssection was added between cross sections 163, 206, and 244.

For model calibration, water levels in the cross sections were measured at five different discharges, ranging from $6.90 \mathrm{ft}^{3} / \mathrm{s}$ to $122 \mathrm{ft}^{3} / \mathrm{s}$ (table 3.19 ). Initial roughness coefficients were determined for each cross section by back-calculation of Manning Equation at the calibration discharges. The calibration discharges were modeled at normal depth at the most downstream modeled section and a slope of $0.0100 \mathrm{ft} / \mathrm{ft}$ was input as a downstream boundary condition.

The discharges used for model calibration $(6.90,14.00$, 17.5 , and $122 \mathrm{ft}^{3} / \mathrm{s}$ ) were determined from stage-discharge ratings at the Green River streamflow-gaging station. The HECRAS model was calibrated by changing roughness coefficients for each cross section as required until calculated water-surface altitudes matched measured water-surface altitudes with reasonable accuracy. The calibration accuracy was $0.0063 \mathrm{ft}$ over the entire reach for the measured discharges.

Indicators of the bankfull water line were identified in the field. Discharges that corresponded to the bankfull water line were determined from the calibrated model to be about $200 \mathrm{ft}^{3} / \mathrm{s}$.

The calibrated HEC-RAS model was used to produce a staging table of hydraulic parameters for 49 discharges between 1 and $320 \mathrm{ft}^{3} / \mathrm{s}$ for the cross sections at stations 100, 163, 206, and 244. The cross sections at stations 163, 206, and 244 were used for determination of streamflow requirements by use of the R2Cross and Wetted Perimeter methods. The staging table was used to determine streamflow requirements by using R2Cross criteria (table 3.20).

The limiting R2Cross criterion or last of the three criteria to be met was the mean velocity for the cross sections at stations 163,206 , and 244. The second criterion to be met was mean depth for stations 206, and 244 and percent of bankfull wetted perimeter for station 163 . The average R2Cross streamflow requirement for the three cross sections, based on the streamflow that meets 2-of-3 hydraulic criteria, was $18 \mathrm{ft}^{3} / \mathrm{s}\left(0.423 \mathrm{ft}^{3} / \mathrm{s} / \mathrm{mi}^{2}\right)$. The average R2Cross streamflow requirement for the three cross sections, based on the streamflow that meets all three hydraulic criteria, was $35.6 \mathrm{ft}^{3} / \mathrm{s}$ $\left(0.84 \mathrm{ft}^{3} / \mathrm{s} / \mathrm{mi}^{2}\right)$.

A wetted perimeter-discharge relation was determined for the cross sections at stations 163,206 , and 244 on the basis of the HEC-RAS model results. The average Wetted-Perimeter streamflow requirement for the three cross sections was $13.67 \mathrm{ft}^{3} / \mathrm{s}$ or $0.32 \mathrm{ft}^{3} / \mathrm{s} / \mathrm{mi}^{2}$. Breaks in the wetted perimeter discharge relation that correspond to toe-of-bank elevations identified during site surveys were used to determine a WettedPerimeter streamflow requirement of about 7.0, 16.0, and 18.0 for the cross sections at stations 163, 206, and 244, respectively. For these stations, the maximum channel depths were about $0.96,1.13 \mathrm{ft}$, and 0.86 ; the average mean water depths in the riffle were $0.64,0.50 \mathrm{ft}$, and 0.38 the average mean velocities were $0.65,0.43$, and $0.52 \mathrm{ft} / \mathrm{s}$, and the average wetted perimeters were 82,80 , and 57 percent of the bankfull wetted perimeter, respectively. 


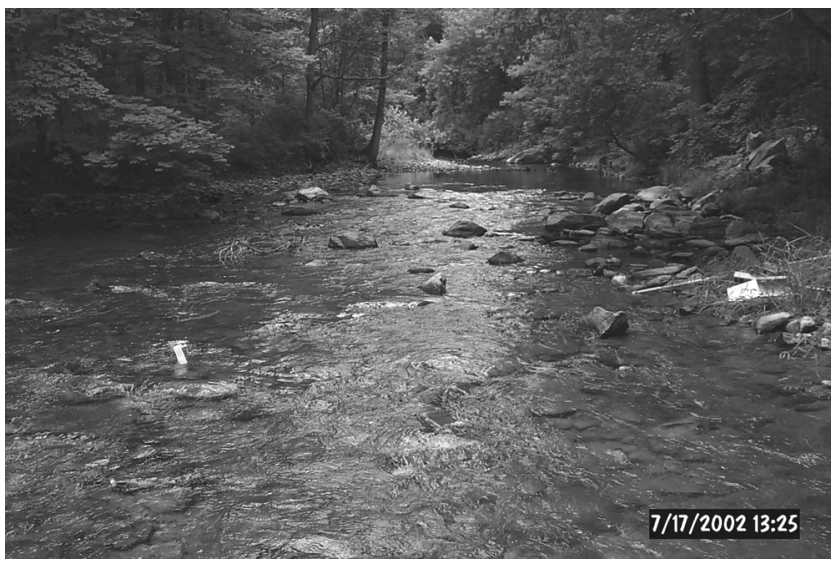

Figure 3-10. Riffle habitat on the Green River near Williamstown, MA, upstream view.

Table 3-19. Hydraulic variables simulated by HEC-RAS for the streamflows used for model calibration, Green River near Williamstown, MA.

[River station: Numbers increase in an upstream direction. $\mathrm{ft}^{3} / \mathrm{s}$, cubic foot per second; $\mathrm{ft}$, foot; $\mathrm{ft} / \mathrm{ft}$, foot per foot; $\mathrm{ft}^{2}$, square foot; -, no data]

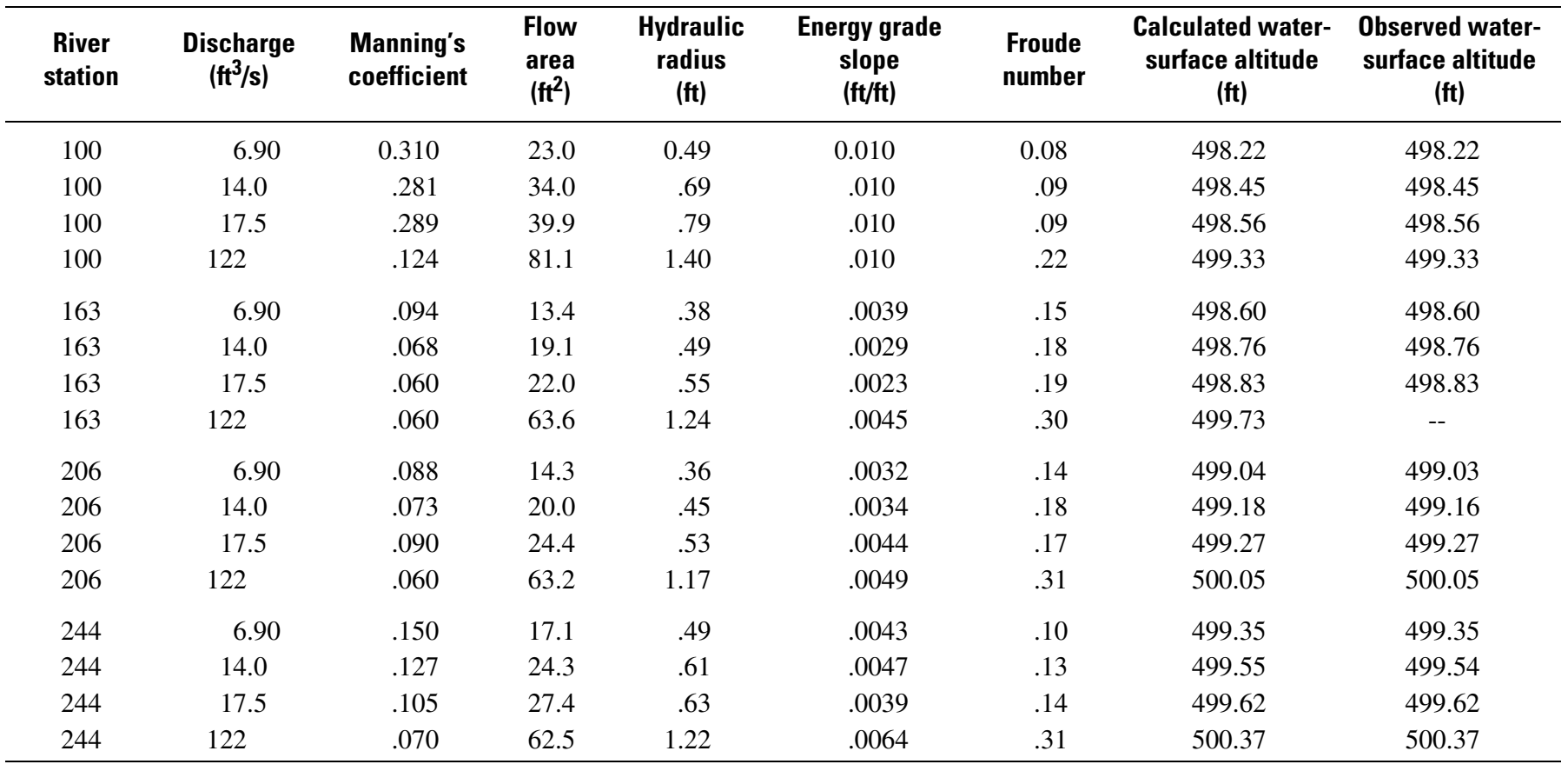


Table 3-20. Hydraulic variables simulated by HEC-RAS for the streamflows meeting R2Cross criteria for determination of streamflows for habitat protection Green River near Williamstown, MA.

[ $\mathrm{ft}^{3} / \mathrm{s}$, cubic foot per second; $\mathrm{ft}$, foot; ft/s, foot per second]

\begin{tabular}{|c|c|c|c|c|c|c|c|}
\hline $\begin{array}{l}\text { River } \\
\text { station }\end{array}$ & $\begin{array}{c}\text { Discharge } \\
\left(\mathrm{ftt}^{3} / \mathrm{s}\right)\end{array}$ & $\begin{array}{c}\text { Top width } \\
\text { (ft) }\end{array}$ & $\begin{array}{c}\text { Wetted } \\
\text { perimeter } \\
\text { (ft) }\end{array}$ & $\begin{array}{c}\text { Average } \\
\text { velocity } \\
\text { (ft/s) }\end{array}$ & $\begin{array}{c}\text { Average } \\
\text { depth } \\
\text { (ft) }\end{array}$ & $\begin{array}{c}\text { Maximum } \\
\text { depth } \\
\text { (ft) }\end{array}$ & Notes \\
\hline 163 & 32.5 & 44.1 & 44.4 & 1.00 & .74 & 1.34 & Meets 3 -of-3 criteria. \\
\hline 163 & 27.0 & 43.2 & 43.5 & .93 & .67 & 1.19 & Meets 2 -of-3 criteria. \\
\hline 206 & 20.0 & 46.5 & 46.7 & .76 & .57 & 1.21 & Meets 2-of-3 criteria. \\
\hline 244 & 200 & 52.8 & 54.0 & 2.33 & 1.63 & 2.15 & Bankfull discharge. \\
\hline 244 & 40.0 & 45.9 & 46.6 & 1.00 & .88 & 1.34 & Meets 3-of-3 criteria. \\
\hline 244 & 8.00 & 35.0 & 35.2 & .44 & .53 & .71 & Meets 2 -of-3 criteria. \\
\hline
\end{tabular}


For additional information write to:

Chief, Massachusetts-Rhode Island District U.S. Geological Survey

10 Bearfoot Road

Northborough, MA 01532

or visit our Web site at

http://ma.water.usgs.gov 

